PAULO EDUARDO OLIVEIRA COSTA

\title{
Legislação urbanística e crescimento urbano em São José dos Campos
}

Dissertação apresentada à Faculdade de Arquitetura e Urbanismo da Universidade de São Paulo para obtenção do título de Mestre em Arquitetura e Urbanismo.

Área de Concentração: História e Fundamentos da Arquitetura e do Urbanismo

Orientadora: Professora Doutora Rebeca Scherer 


\section{FOLHA DE APROVAÇÃO}

Paulo Eduardo Oliveira Costa

Legislação urbanística e crescimento urbano em São José dos Campos

Dissertação apresentada à Faculdade de Arquitetura e Urbanismo da Universidade de São Paulo para obtenção do título de Mestre.

Área de Concentração: História e Fundamentos da Arquitetura e do Urbanismo

Aprovado em:

\section{Banca Examinadora}

Prof. Dr.

Instituição: Assinatura:

Prof. Dr.

Instituição: Assinatura:

Prof. Dr.

Instituição: Assinatura:

Prof. Dr.

Instituição: Assinatura:

Prof. Dr.

Instituição: Assinatura:

Prof. Dr.

Instituição: Assinatura: 


\section{AGRADECIMENTOS}

À minha orientadora Professora Doutora Rebeca Scherer, pelas críticas e sugestões precisas e oportunas durante o acompanhamento deste trabalho.

À Professora Doutora Marta Soban Tanaka pelas sugestões para a conclusão desta pesquisa.

À banca de qualificação, composta pelos professores Klara Kaiser Mori e Emílio Haddad, pelas observações pertinentes e pelas sugestões bibliográficas que contribuíram para a complementação da pesquisa.

Aos meus amigos: Celeste, Cidóca, Cristiane, Doriane, Douglas, Eliana, Fátima, Fernanda, Ingrid, Neusa, Rodolfo, Sílvia, William e aos colegas da Prefeitura Municipal de São José dos Campos pelo incentivo.

Aos meus pais, familiares,Terezinha e ao Adilson pela tolerância, paciência e apoio afetivo. 


\section{RESUMO}

COSTA, P. E. O. Legislação urbanística e crescimento urbano em São José dos Campos. 2007. 257 f. Dissertação de Mestrado - Faculdade de Arquitetura e Urbanismo, Universidade de São Paulo, São Paulo, 2007.

Este trabalho consiste no estudo da legislação urbanística de São José dos Campos, aqui entendida como os Planos Regionais e Planos Diretores Municipais, bem como o conjunto da regulamentação referente ao parcelamento, uso e ocupação do solo e as edificações, no período compreendido entre o início dos anos 50 e 2000. A legislação urbanística é um fator fundamental da estruturação do Habitat e, portanto, das condições de vida do conjunto da população. Tanto a legislação, quanto o sistema de planejamento e a forma de organização desse sistema o são. São José dos Campos apresenta condições que a tornam importante receptora de investimentos, mas não podemos deixar de considerar seu baixo desempenho quanto aos índices de qualidade de vida. Evidenciamos os efeitos ocasionados pela legislação e a ocorrência simultânea de más condições de vida da população de baixa renda com o intuito de compreender o processo e a consolidação do planejamento urbano em São José dos Campos. Procedemos a três análises e tendências que enfocam três regiões da cidade, justamente aquelas que apresentam ocupação não regularizada, sem infra-estrutura e que foi causada pela segregação de uma parte da população que, devido à especulação imobiliária, vem se deslocando do centro para a periferia, considerando o valor dos imóveis ou, em outra situação, pela relocação de loteamentos clandestinos localizados em trechos agora valorizados. Trazemos para discussão algumas contribuições para futuras revisões relativas ao conjunto da legislação urbanística existente em São José dos Campos.

Palavras chave: São José dos Campos, legislação, urbanização, planejamento municipal e regional, conurbação e segregação espacial. 


\begin{abstract}
COSTA, P. E. O. Urban legislation and the growing process of São José dos Campos, 2007. 257 f. Master Degree Paper - University of São Paulo - Architecture and Urbanism College, São Paulo, 2007.

This paper is about the study of the urbanistic legislation of São José dos Campos, hereby described as Regional Plans and City Master Plan, as well as the group of rules over division, use and land occupation and building, during the period of 1950 s until the year 2000. The urbanistic legislation is a key factor of the habitat structure and the living conditions of the population as a group. Not only the legislation but also the planning system and its organization reflect this factor. São José dos Campos has features that make it an important center of investments but, we must bear in mind that the city HDI (Human Development Index) is still low. We demonstrate the effects caused by the legislation and, its relation with low income populations still suffering with bad life quality, so as to understand the process and the consolidation of the urban planning in São José dos Campos. Three analysis and tendencies were performed over three regions of the city mostly affected by no regular occupation and no infrastructure. All these caused by the segregation of a segment of the population that, due to the realty speculation, is being moved from center areas of the city to suburban areas, considering real estate prices and in some cases, by the replacement of illegal developments located now in highly developed and expensive areas. Some contributions are brought up for discussion for future revisions relating to the present group of urbanistic legislation applied in São José dos Campos.
\end{abstract}

Keywords: São José dos Campos, legislation, urbanistic process, regional and city planning, conurbation and spatial segregation 


\section{LISTA DE ILUSTRAÇÕES}

Figura 1.1 - Eixo viário e limite entre São José dos Campos e Jacareí ........................................... 37

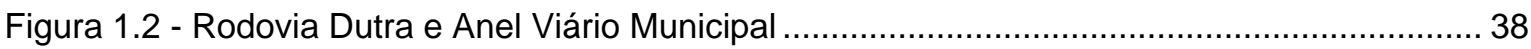

Figura 1.3 - Rodovia Carvalho Pinto e Rodovia dos Tamoios ....................................................... 39

Figura 1.4 - Trecho urbano da Rodovia dos Tamoios (SP-99) que dá acesso ao Litoral Norte...... 40

Figura 1.5 - Região Norte e Rodovia SP-50 acesso ao Sul de Minas ............................................ 41

Figura 1.6 - Limite Oeste de São José dos Campos conurbado com Jacareí .................................. 42

Figura 1.7 - Conurbação com Caçapava - limite Leste ............................................................... 43

Figura 1.8 - Bairro do Campo dos Alemães e Conjunto Habitacional Dom Pedro I e II ................... 44

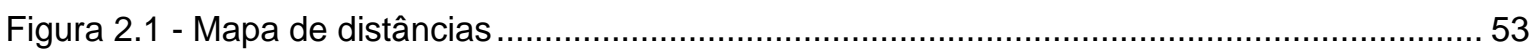

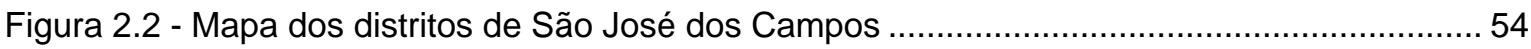

Figura 2.3 - Distribuição da População Segundo Regiões Urbanas................................................ 57

Figura 2.4 - Mapa das Regiões Administrativas do Estado de São Paulo ...................................... 59

Figura 2.5 - 3 ${ }^{a}$ Região Administrativa de São José dos Campos ..................................................... 59

Figura 2.6 - Sanatório Vicentina Aranha e início da verticalização do seu entorno .......................... 67

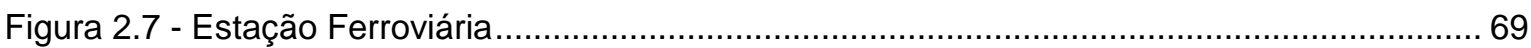

Figura 2.8 - Avenida São José e orla do Banhado na Região Central. .......................................... 73

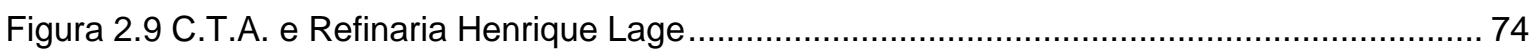

Figura 2.10 - Avenida João Guilhermino e as Palmeiras Imperiais ............................................... 75

Figura 2.11 Jardim Nova América e Esplanada I e II - SJC ......................................................... 76

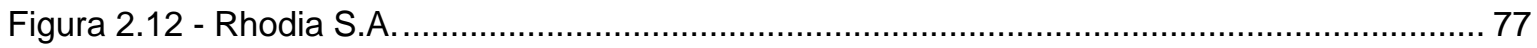

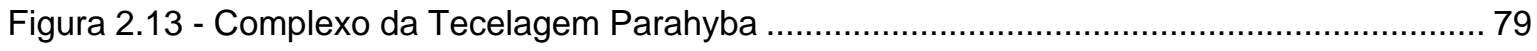

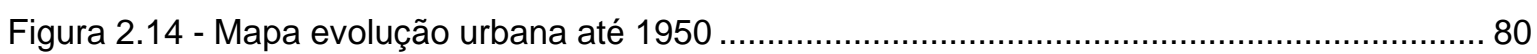

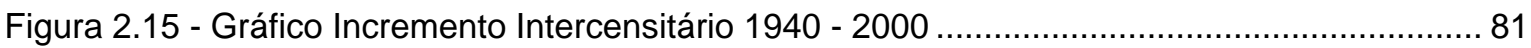

Figura 2.16 - Bosque da Johnson's e plantação de pinheiros da Kodak......................................... 84

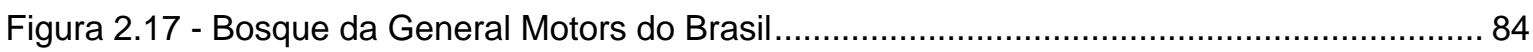

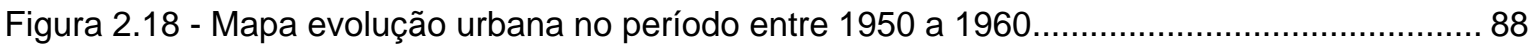

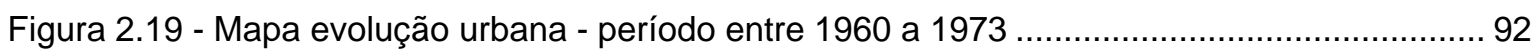

Figura 2.20 - Conjuntos habitacionais na Região Leste e o Projeto CURA. .................................... 94

Figura 2.21 - Quadra destinada aos equipamentos comunitários: Teatro, Tiro de Guerra, Hospital,

Pronto Socorro, Velório Municipal, Urbam S/A (Urbanizadora Municipal) e complexo poliesportivo

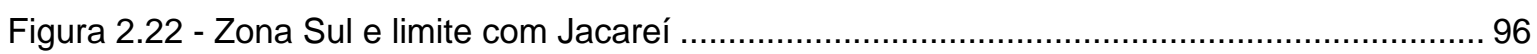

Figura 2.23 - Mapa evolução urbana - período entre 1973-1978 ….......................................... 100

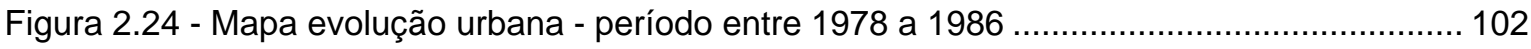

Figura 2.25 - Mapa evolução urbana - período entre 1986 a 1989 ............................................ 104

Figura 2.26 - Mapa evolução urbana - período entre 1989 a 2005. ............................................. 105

Figura 2.27 - Ocupação irregular na Região Leste do município. ................................................ 107 
Figura 3.1 - Faixa industrializada ao longo da Via Dutra ......................................................... 135

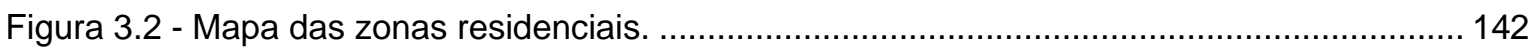

Figura 3.3 - Proposta de alargamento viário para a área central ............................................ 147

Figura 3.4 Organograma do Escritório Técnico de Planejamento ................................................. 151

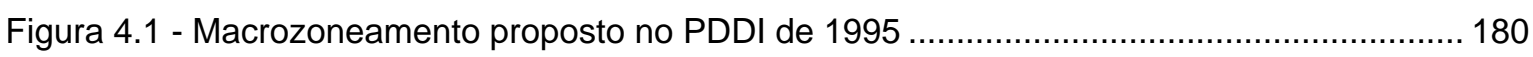

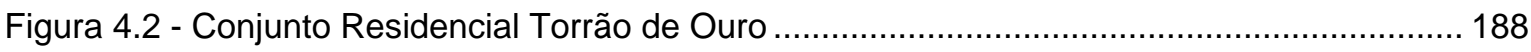

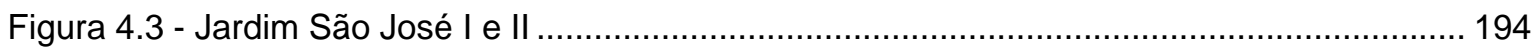

Figura 4.4 - Mapa de Vulnerabilidade Social Paulista ................................................................... 215

Figura 4.5 - Mapa do Zoneamento de 1997 e áreas a serem analisadas ................................... 217

Figura 4.6 - Mapa de fases dos novos loteamentos e áreas a serem analisadas.......................... 218

Figura 4.7 - Mapa dos Setores Socioeconômicos ……....................................................... 219

Figura 4.8 - Mapa de habitantes por setores econômicos ........................................................... 220

Figura 4.9 - Foto aérea com os principais obstáculos (CTA, Petrobrás e Banhado) e principais

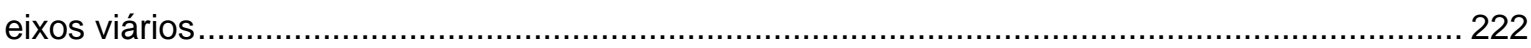

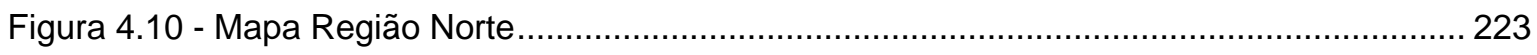

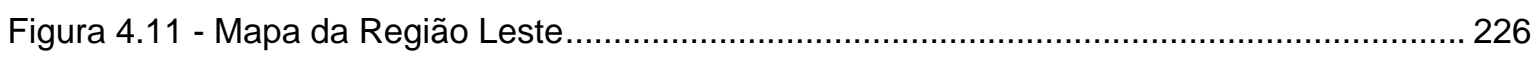

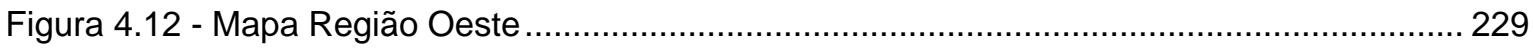

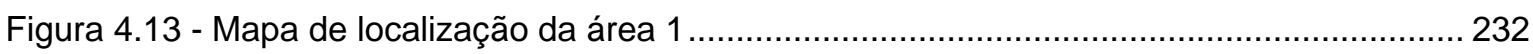

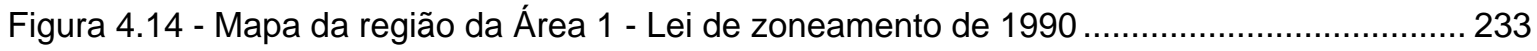

Figura 4.15 - Mapa com a proposta viária para a Região Norte - PDDI 2006 ............................... 234

Figura 4.16 - Mapa da proposta viária do Plano Diretor para o Parque da Cidade........................ 235

Figura 4.17 - Mapa do zoneamento proposto no Plano Diretor do Parque da Cidade................... 236

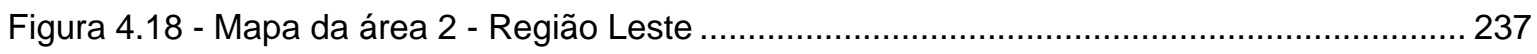

Figura 4.19 - Zona de Vazio Urbano - Lei Municipal 3721/90 ................................................ 238

Figura 4.20 - Mapa da proposta viária para a Região Leste - PDDI 2006.................................... 239

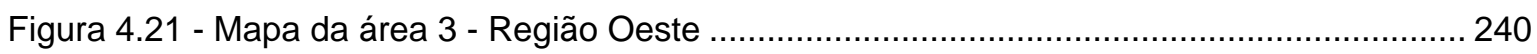

Figura 4.22 - Zoneamento da Região Oeste - Lei Municipal 3721/90 ....................................... 241

Figura 4.23 - Mapa da proposta viária para a Região Oeste - PDDI 2006 …............................. 242

Figura 4.24 - Foto aérea e limite entre São José dos Campos e Jacareí - Região Oeste ............. 243 


\section{LISTA DE TABELAS}

Tabela 1.1 - Distribuição Espacial do VTI da indústria de transformação Brasil, unidades da Federação e Regiões selecionadas - 1970 a 1996

Tabela 1.2 - Classificação de São José dos Campos em relação aos municípios do Estado de São Paulo.

Tabela 1.3 - São José dos Campos e os principais índices de qualidade de vida 50

Tabela 1.4 - A evolução do IDH-M e seus componentes - São José dos Campos. 50

Tabela 1.5 - Índices de esperança de vida, alfabetização, freqüência escolar e renda per capita. 50

Tabela 2.1 - Evolução populacional do Município 1940-2000 56

Tabela 2.2 - População Segundo Regiões Urbanas Município de São José dos Campos - 2000 . 56

Tabela 2.3 -Taxa de Crescimento da População Segundo Regiões Urbanas Município de São José dos Campos - 1991-2000 57

Tabela 2.4 - Estimativas populacionais e projeção da população Município de São José dos Campos 58

Tabela 2.5 - População de São José dos Campos relativa a região administrativa do Vale do Paraíba e Estado de São Paulo. 61

Tabela 2.6 - Evolução da população total segundo seus componentes - Região Administrativa do Vale do Paraíba - 1940/1970

Tabela 2.7 - População das sedes municipais - São José dos Campos, Taubaté, Caçapava e Jacareí

Tabela 2.8 - População dos principais municípios - São José dos Campos, Taubaté, Caçapava e Jacareí - 1970/1996.

Tabela 2.9 - Taxa média de crescimento, taxa de urbanização e índices migratórios 64

Tabela 2.10 - Evolução populacional do Município - 1940-2000

Tabela 4.1 - Relação das favelas indicadas para ZEIS 1 em 1996.

Tabela 4.2 - Moradias sem condições básicas adequadas de habitação em São José dos Campos $-2003$.

Tabela 4.3 - Domicílios alugados com condições básicas adequadas de habitação, de acordo com o comprometimento da renda da família principal com o pagamento do aluguel, por faixas de salários mínimos - Município de São José dos Campos - 2003. 192 
Tabela 4.5 - População segundo regiões - Município de São José dos Campos - 2000

Tabela 4.6 - Região Norte 24 Setor Freitas/Sertãozinho ......................................................... 224

Tabela 4.7 - Região Leste 30 Setor Capão Grosso/ Bom Retiro/ Serrote ….................................. 227

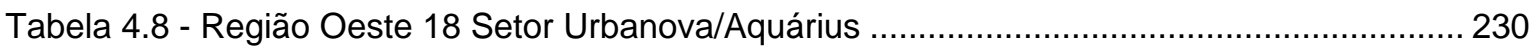




\section{SUMARIO}

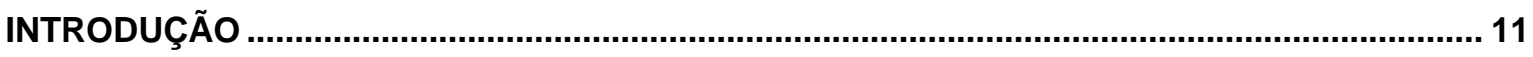

CAPÍTULO 1 - A CONFIGURAÇÃO DO ESPAÇO URBANO REGIONAL.................................... 18

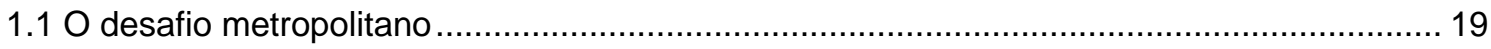

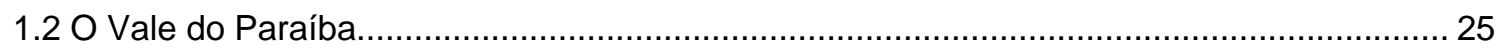

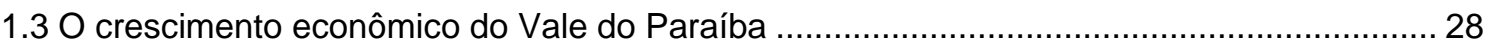

1.4. A construção do Pólo Regional de São José dos Campos .................................................. 45

CAPÍTULO 2 - CARACTERIZAÇÃO DO MUNICÍPIO DE SÃO JOSÉ DOS CAMPOS.................. 53

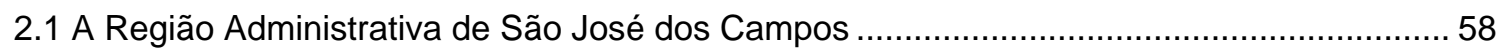

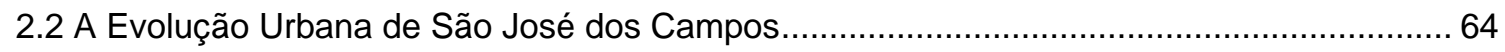

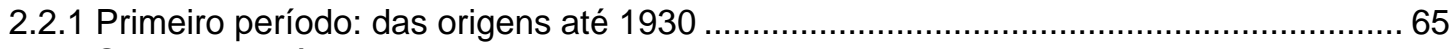

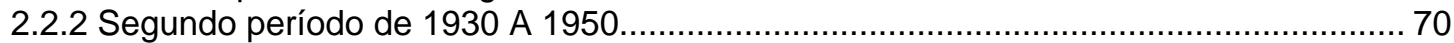

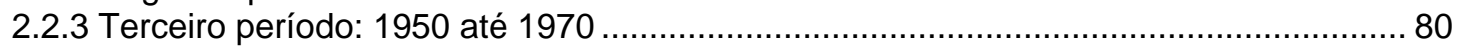

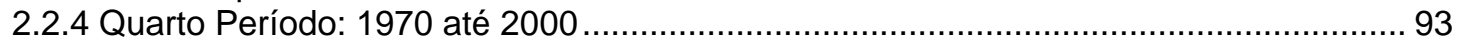

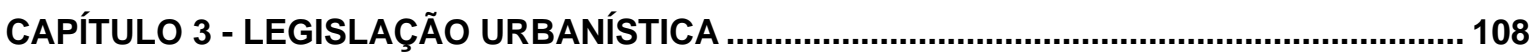

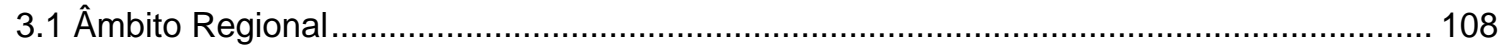

3.1.1 Os Primeiros Planos Regionais para o Vale do Paraíba........................................... 108

3.1.2 Consórcio de Desenvolvimento Integrado do Vale do Paraíba e Litoral Norte............. 111

3.1.3 O Plano Regional para o Macro-Eixo Paulista .......................................................... 122

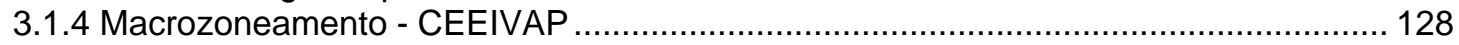

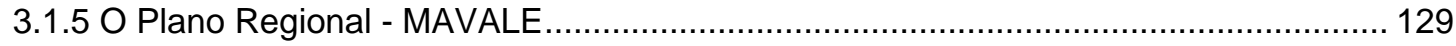

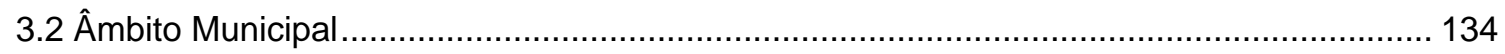

3.2.1 A primeira Lei de Zoneamento de São José dos Campos......................................... 134

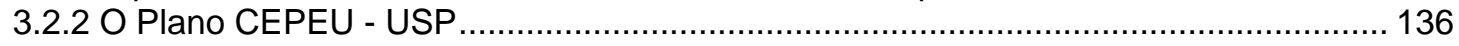

3.2.3 Análise do Plano CEPEU - USP.......................................................................... 151

3.2.4 O Plano Diretor SERETE S.A. (1969-1971) .................................................................. 155

3.2.5 A Lei de Parcelamento e a Lei de Zoneamento de 1970 ........................................ 161

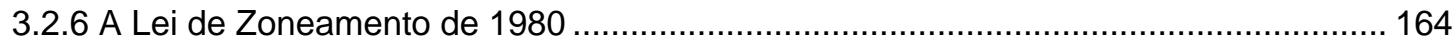

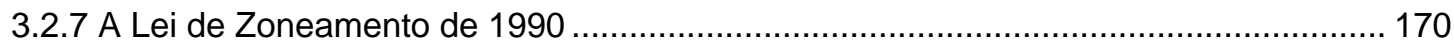

CAPÍTULO 4 - O PDDI de 1995 “UM PLANO DA CIDADE PARA A CIDADANIA”..................... 176

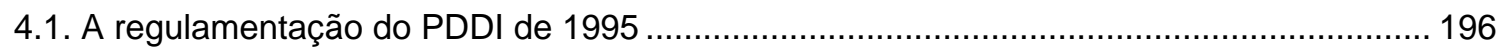

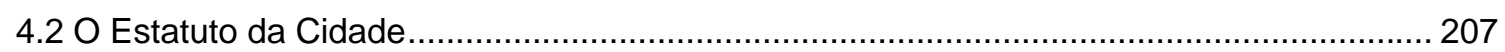

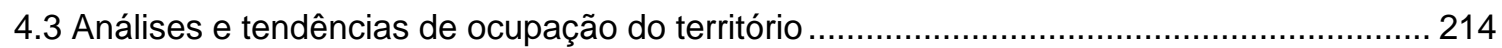

4.3.1 Perfil socioeconômico das regiões .................................................................. 218

4.3.2 Análise das áreas e suas tendências ................................................................ 231

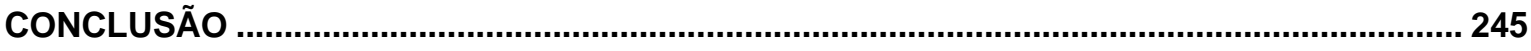

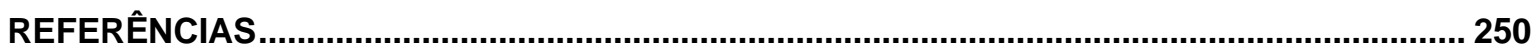

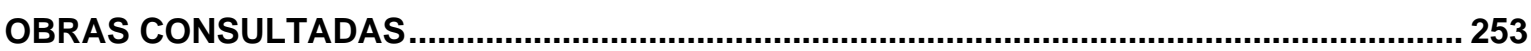




\section{INTRODUÇÃO}

Esta pesquisa consiste na observação do crescimento urbano de São José dos Campos, cidade localizada na Região do Alto Paraíba do Sul, Estado de São Paulo tendo como eixo a legislação urbanística.

O objeto de estudo deste trabalho é o conjunto da legislação urbanística de São José dos Campos - aqui entendido como os Planos Regionais e Diretores Municipais e o conjunto de regulamentações referentes ao parcelamento, uso e ocupação do solo e, ainda, às edificações desse município e sua inserção nos planos regionais para o Vale do Paraíba.

O recorte temporal escolhido para este estudo de caso é o período compreendido entre o início da década de 50 e o ano de 2000, por tratar-se do período em que ocorreu o incremento mais intenso de urbanização e a promulgação de significativa legislação urbanística.

As informações estatísticas utilizadas são provenientes dos trabalhos da Prefeitura Municipal de São José dos Campos, do Instituto Brasileiro de Geografia e Estatística - IBGE, da Fundação SEADE e da pesquisa Atlas das condições de vida da população de São José dos Campos. Esse Atlas foi elaborado a partir da base de dados da Pesquisa de Instrumentação do Planejamento Urbano e Avaliação do Déficit Habitacional em São José dos Campos de 2003, projeto realizado no âmbito de um convênio de cooperação técnica que reuniu a Secretaria de Planejamento da Prefeitura Municipal de São José dos Campos e o Núcleo de Estudos de População (NEPO) da UNICAMP.

O Atlas das Condições de Vida em São José dos Campos apresenta um valioso conjunto de informações sobre as condições de vida nos diversos setores da cidade e demonstra a situação da população residente, destacando a segregação sócioespacial que acabou por criar espaços socialmente diferenciados. 
Concomitantemente ao levantamento bibliográfico, foram coletados dados cartográficos, imagens de satélite e geoprocessamento do município que foram úteis para identificação e comparação das áreas de vulnerabilidade social estudadas pela Fundação SEADE.

Com efeito, o processo industrial da década de 50 trouxe para a São José dos Campos um aumento populacional significativo e a difusão de uma economia urbanoindustrial. Mas foi na década de 70 que ocorreu o seu processo de urbanização mais intenso.

Os anos 50 podem ser considerados o marco referencial da industrialização contemporânea e da dinamização da urbanização de São José dos Campos, pois a cidade destacou-se pela forte aceleração na taxa de crescimento demográfico e, nas décadas subseqüentes, por ser um dos municípios brasileiros com grande crescimento econômico. Por outro lado, o município vem apresentando baixo desempenho em relação aos índices de qualidade de vida, incompatível com seu desenvolvimento econômico.

Atualmente, São José dos Campos é sede de um aglomerado urbano que inclui as cidades de Jacareí, Taubaté e Caçapava, ao longo do eixo rodoviário que liga as áreas metropolitanas de São Paulo e Rio de Janeiro e destaca-se como um dos centros econômicos mais relevantes do Estado e do Brasil.

Sua posição estratégica e a proximidade do Porto de São Sebastião que apresenta grandes potencialidades para a movimentação de cargas especializadas, o processo de desconcentração industrial, principalmente de São Paulo, bem como a implantação do Centro Técnico Aeroespacial - CTA e do Instituto Nacional de Pesquisas Espaciais - INPE, são alguns dos fatores que explicam a existência de um parque industrial diversificado que, em 2006, contava com 1235 estabelecimentos. 
Conforme índices ${ }^{1}$ sobre o Produto Interno Bruto - PIB, São José dos Campos é o $9^{\circ}$ colocado dos 5.560 municípios do país. Segundo essa pesquisa, esses nove municípios brasileiros respondem por $25 \%$ da produção de bens e serviços brasileiros. São José dos Campos teve também sua economia impulsionada pelo aumento das exportações ocorrido nos últimos anos.

De acordo com o levantamento divulgado pelo CIESP de Campinas, em 2004, as empresas de São José dos Campos exportaram um total de US\$ 4.7 bilhões e, nesse ano, o município passou a ser o primeiro exportador do estado mais rico do Brasil, ultrapassando os números da capital paulista.

Mesmo considerando que São José dos Campos apresenta condições que a tornam importante receptora de investimentos, não podemos deixar de considerar seu baixo desempenho quanto aos índices de qualidade de vida - $(\text { IDH })^{2}$ - índice de esperança de vida (IDHM-L) é a $114^{\circ}$, índice de educação (IDHM-E) é a $6^{\mathrm{a}}$, índice de PIB (IDHM-R) é a $21^{\mathrm{a}}$ e no índice geral de desenvolvimento humano (IDH-M) ocupa a $37^{\text {a }}$ posição no ranking do IDH-M entre todos os municípios do Brasil, e a 11aㅡ posição, entre os 645 municípios paulistas.

Do ponto de vista do desenvolvimento urbano o desempenho de São José dos Campos deixa a desejar. Na observação da cidade, cujo relato é objeto do Capítulo 1, foi possível identificar problemas intra-urbanos, tais como dispersão territorial; barreiras viárias (Via Dutra); vazios urbanos; falta de integração viária; falta de uma política habitacional de interesse social; qualidade ambiental; gestão urbana; urbanização e legalização dos assentamentos precários; geração de recursos para habitação de interesse social.

\footnotetext{
${ }^{1}$ Jornal Folha de São Paulo de 03 de maio de 2005.

${ }^{2}$ Concebido pela Organização das Nações Unidas (ONU) originalmente para medir o nível de desenvolvimento humano de países, através das dimensões longevidade, educação e renda, o IDH foi adaptado para ser utilizado como instrumento de avaliação de agrupamentos sociais menores - como os municípios -, surgindo assim o IDH-M.
} 
Diante desses índices e desses problemas, podemos dizer, numa abordagem preliminar, que todo o desenvolvimento econômico ocorrido em São José dos Campos não conseguiu trazer correspondente retorno para a qualidade de vida urbana local, conforme apresentado no Capítulo 2.

Scherer (1994) coloca-nos uma questão sobre as condições de vida das cidades brasileiras e latino-americanas que a seu ver

de um modo geral, continuam evidenciando problemas gravíssimos de habitação, transporte, saneamento básico, violência, educação, saúde, etc, para os quais não têm sido elaboradas políticas públicas conseqüentes e nem propostas eficientes e eficazes das instituições de planejamento que estão em funcionamento.

Esta dissertação procura trazer para discussão algumas contribuições para futuras revisões relativas ao conjunto da legislação urbanística ${ }^{3}$ existente na cidade de São José dos Campos, apresentada no Capítulo 3, de modo a contribuir para melhoria das condições de vida urbana e de seus habitantes.

Pretendemos trazer subsídios para adequações e aprimoramentos nas futuras revisões na legislação urbanística e para tanto, resgataremos a história do planejamento urbano de São José dos Campos e, por meio da análise dos instrumentos de planejamento, procederemos à avaliação de suas políticas de planejamento urbano, que serão tratadas no Capítulo 4.

A legislação urbanística, embora seja o elemento mais desenvolvido dentro da disciplina de urbanismo, no Brasil, nas últimas cinco décadas, deixa ainda muito a desejar. Como afirma Feldman, "Ainda que, a referência à legislação esteja presente na maior parte dos estudos sobre o urbanismo do Brasil, a legislação é, de certa forma, naturalizada e, com raras exceções, não ultrapassa o caráter de identificação das leis, por meio da listagem e descrição de seus conteúdos" (FELDMAN, 2005, p. 23).

\footnotetext{
${ }^{3}$ Entendemos como conjunto de legislação urbanística - o conjunto de leis, decretos e normas urbanísticas e de construção que regulam a produção do espaço da cidade.
} 
Segundo a mesma autora, na produção acadêmica mais recente identificamos três vertentes dominantes nas pesquisas voltadas para a historiografia da legislação urbanística no Brasil. A primeira vertente enfoca os aspectos normativos referentes à propriedade fundiária até a promulgação da Lei de Terras, em 1850, quando a terra adquire o estatuto de mercadoria.

A segunda vertente se caracteriza por estudos que têm como marco temporal a Primeira República, nos quais prevalece a interpretação da legislação como instrumento de dominação e normatização da vida das classes populares e de atividades que se incluem na esfera das ilegalidades urbanas, referenciado nos processos higienistas.

Uma terceira vertente se caracteriza pela precedência de estudos voltados para os efeitos, repercussões e impactos no espaço urbano da aplicação da legislação, que têm como referência, a escala assumida pela expansão das cidades brasileiras mediante estratégias de solução de problemas da moradia à margem da legislação loteamentos clandestinos, cortiços e favelas.

Nesta vertente, podem ser destacados os estudos centrados na inefetividade da lei (Grostein, 1987; Rolnik, 1997); estudos que enfatizam a relação entre a legislação e a valorização imobiliária (Souza, 1994; Somekh, 1987, 1996) e estudos que, por meio de uma visão panorâmica da legislação, apontam seus efeitos no processo de planejamento (Rezende, 1997) e na configuração da paisagem urbana (Medina, 1997).

De modo geral, a discussão em torno da legislação urbanística se concentra sobre seus efeitos e o papel no processo de desenvolvimento urbano em geral desigual e segregador.

Este estudo aborda a legislação urbanística de São José dos Campos - aqui entendida como os Planos Regionais e Diretores municipais e o conjunto da regulamentação referente ao parcelamento, uso e ocupação do solo e às edificações da cidade. São enfatizados os preceitos da terceira vertente, uma vez que o nosso objetivo 
geral é identificar, avaliar e analisar as políticas públicas ${ }^{4}$, os instrumentos de planejamento e programas utilizados no processo urbanização.

Além de tratar dos efeitos ocasionados pela legislação e a ocorrência simultânea das más condições de vida para as populações de baixa renda buscamos também compreender o processo e a consolidação da prática do planejamento em São José dos Campos.

Partimos do princípio que a legislação urbanística é um fator fundamental da estruturação do Habitat e, portanto, das condições de vida do conjunto da população. Tanto a legislação, quanto o sistema de planejamento e a forma de organização desse sistema o são. Acreditamos que o trabalho aqui sistematizado pode vir a constituir uma contribuição para o tratamento das questões no município.

A metodologia adotada baseia-se na abordagem histórico-estrutural, ou seja, aborda a história evidenciando as diferenças estruturais entre os agentes sociais, bem como, as peculiaridades do processo de urbanização em cada formação social e a articulação entre as múltiplas variáveis que abrange: política, social, econômica e espacial. Utilizamos a perspectiva histórica articulando espaço e tempo e colhendo as evidências das transformações recentes para entender as relações entre o conjunto de legislação urbanística e as condições de vida da população.

Uma das questões presentes no trabalho e que contribui para a análise dos problemas intra-urbanos em São José dos Campos tem como suporte conceitos de desenvolvimento sócio-econômico e de qualidade de vida. Esta questão acompanhará nossa interlocução com os vários autores que trabalharam o tema, "numa perspectiva crítica e que considera o crescimento econômico como uma das condições necessárias

\footnotetext{
${ }^{4}$ Entendemos como política pública o conceito de política e de administração que designa certo tipo de orientação para a tomada de decisões em assuntos públicos, políticos ou coletivos. Segundo Guareschi et all (2004, p.180), "é o conjunto de ações coletivas voltadas para a garantia dos direitos sociais, configurando num compromisso público que visa dar conta de determinada demanda em diversas áreas"
} 
para o desenvolvimento humano, mas não como uma condição suficiente e com vinculação automática com este." (AMARTHYA, 1993)

Segundo Mori (1996),

o crescimento econômico vem acompanhado do crescimento urbano, mas nem sempre do aumento dos benefícios sociais. Riqueza e pobreza coexistem em uma cidade do Estado mais desenvolvido do Brasil e em uma de suas regiões mais desenvolvidas economicamente. $\mathrm{O}$ espaço de uma sociedade é constituído pelo movimento de sua transformação, pelo campo de intermediações concretas através das quais cada parcela singular participa do (e determina o) espaço social, e é por ele determinado.

Fatores novos na presente etapa de globalização tais como a mudança do papel dos Estados, os novos reordenamento espaciais, o aumento da fluidez e das conexões, a mundialização da produção, da circulação e do consumo são elementos importantes para delinearmos o atual período.

Com a finalidade de verificar as formas que essa legislação urbanística vem modificando o território e compreendermos a prática do planejamento de São José dos Campos procedemos algumas análises pontuais nas regiões Norte, Leste e Oeste desse Município, que adiante será tratado com mais detalhe no item 4.3 do Capítulo 4. 


\section{CAPÍTULO 1 - A CONFIGURAÇÃO DO ESPAÇO URBANO REGIONAL}

O Estado de São Paulo está localizado na Região Sudeste do Brasil, possui 645 municípios distribuídos em uma área de $248.809 \mathrm{~km}^{2}$ e abriga uma população que ultrapassou 40 milhões no ano de 2005. O Estado possui a mais ampla e complexa rede urbana $^{5}$ do país.

Parte significativa dos seus municípios forma grandes áreas conurbadas, como é o caso da região metropolitana de São Paulo, localizada no entorno expandido da capital. Este fenômeno também ocorreu nas regiões da Baixada Santista, localizada na expansão da cidade de Santos em direção ao Litoral Norte e Sul; na região metropolitana de Campinas e Vale do Paraíba.

O crescimento da aglomeração metropolitana paulista, que abrange um raio de $150 \mathrm{~km}$, conforma uma paisagem que se apresenta fragmentada, embora constitua uma unidade. "Constata-se a dificuldade de perceber a unidade desta nova metrópole, onde as descontinuidades espaciais são fragmentos de um todo que se distendeu, frações de um todo em expansão que se afirma cada vez mais como o centro do país". (LENCIONI, 1994).

A rede urbana paulista está estruturada a partir da capital e sua constituição remonta ao século XIX quando, a partir do dinamismo econômico impulsionado pelo complexo cafeeiro, o território passou por um processo contínuo e permanente de ocupação.

\footnotetext{
${ }^{5}$ São nos trabalhos de SANTOS (2004) e Ribeiro (1998) que se verifica a existência remota do conceito de Rede, ligado a outras ciências, como no século XVII - que a medicina o empregava para definir a circulação sanguínea e, no século XVIII - a rede tanto servia para se pensar a criação de sistema de fortificações francesas pelos militares, como as galerias de abastecimento de água, pelos engenheiros civis. No caso específico brasileiro, caracteristicamente, possui uma "complexidade genética" (pelo fato dos núcleos urbanos surgirem em vários períodos históricos desde a época remota do descobrimento, como até neste século XXI), Entendemos que a Rede Urbana tem a capacidade de evidenciar a dinâmica espacial e apresenta-se como o estudo da dinâmica espacial da sociedade.
} 
Isso foi possível graças ao inter-relacionamento dos componentes e das variáveis do complexo cafeeiro que engendrou um conjunto de efeitos geradores de economias de escala e de economias externas que, ao mesmo tempo, expandiram mutuamente o mercado e propiciaram uma ampla acumulação de capital, diversificadora do complexo. (CANO, 1977 p. 21-22).

Esses efeitos gestados na economia cafeeira expressaram-se, principalmente, no meio urbano e foram responsáveis pela constituição de um potente mercado estruturado a partir da capital, espalhando-se pelo interior, onde foram privilegiados os pontos nodais da rede de transportes e comercialização do café. A partir desta base, estruturou-se uma complexa e diversificada rede urbana, cujo cume era a capital que, por sua vez, contava com diversos subcentros regionais, a partir dos quais se articulavam todos os núcleos urbanos numa rede única, que abarcou pontos externos ao território estadual, inclusive.

Atualmente, o Estado de São Paulo é responsável por 40\% do Produto Interno Bruto Brasileiro, pela produção anual de bens e serviços e revela uma estrutura econômica de país desenvolvido. O parque industrial é o maior da América Latina e sua agricultura a mais rica do Brasil.

\subsection{0 desafio metropolitano}

As metrópoles surgiram com funções centralizadoras relativamente aos espaços nacionais que as geraram. Hoje, este papel de núcleo de amplas bacias econômicas tende a ser substituído pelo papel de elo numa rede internacional de cidades mundiais, na expressão de Friedmann \& Wolff (1986).

Segundo Lencioni (1994), a reestruturação da metrópole de São Paulo, por exemplo, produto dos processos de concentração e centralização do capital, se traduz num fenômeno socioespacial novo, criação e repetição de uma região metropolitana mais complexa, fragmentada e hierarquizada em que a conurbação de cidades e o 
crescimento, relativamente menor de algumas ou da exacerbação de outras, não significam processos autônomos de metropolização.

(...) ao contrário, são manifestações constituídas da expansão do espaço metropolitano paulista, que se configura numa "macro-metrópole" que é reforçada e não negada pela dispersão das suas atividades e, conseqüentemente, da sua urbanização. (LENCIONI, 1994).

A metropolização da região do Vale do Paraíba vem se impondo desde os anos 70, sendo que São José dos Campos assumiu o papel de metrópole emergente, o que pode ser verificado, principalmente, pelo caráter regional do setor de serviços que dá sustentação à intensificação dos fluxos e relações entre São José dos Campos e as cidades do seu entorno, compondo traços fundamentais do processo de metropolização da região do aglomerado do Vale do Paraíba.

Este desenvolvimento reflete-se nas atividades de comércio e prestação de serviços. A exemplo, a cidade conta com alguns equipamentos do setor terciário comércio varejista em grande escala - próprio das metrópoles, destacando-se assim, dos demais núcleos urbanos da região.

De fato, o interior de São Paulo reúne, desde a década de 90, condições extremamente favoráveis para atrair novos investimentos em razão dos condicionantes de competitividade que se impõem às empresas. Nesse sentido, é importante atentar para os aspectos que, atualmente, se colocam como principais determinantes da localização industrial: dotação de infra-estrutura e possibilidade de estruturar logísticas adequadas de suprimento e escoamento da produção; mercado de trabalho qualificado e mercado profissional dinâmico; boa qualidade de vida; proximidade física com empresas fornecedoras e montadoras; ambiente empresarial; suporte de serviços industriais e de apoio à produção; entre outros.

As cidades do aglomerado valeparaibano ganharam outras dimensões. Multiplicaram-se as interdependências e São José dos Campos assumiu definitivamente as características de um centro regional. 
Uma conurbação embrionária, a partir da Via Dutra, passou a definir um aglomerado urbano de grandes proporções, embora relativamente difuso. Mais relevante ainda, é o adensamento desta rede de cidades e a natureza articulada de seu crescimento.

A industrialização paulista e a modernização de sua agricultura expressaramse no surgimento de áreas concentradas, tradicionalmente chamadas de pólos regionais, dentre os quais São José dos Campos se destaca.

Entretanto, este processo de dinamização/modernização das atividades produtivas não foi acompanhado por transformações que melhorassem as condições de vida para a maioria dos moradores destas cidades. Ao contrário, a especialização de funções, em algumas áreas, produziu uma heterogeneidade dos espaços ocupados que acirraram as desigualdades sociais.

São José dos Campos vive, hoje, um processo de metropolização, fato que pode ser constado pela observação do cotidiano da cidade que indica uma reestruturação do ambiente construído.

Embora o município possua legislação urbanística desde de 1920, podemos observar que, a forma como foram articuladas as dimensões políticas econômicas e sociais do desenvolvimento do município, trouxeram problemas que a legislação ainda não conseguiu estancar. Esta é a questão que orientou o tratamento de nosso objeto de estudo, ou seja: a concomitância entre a existência de expressiva legislação urbanística e as condições de vida da população carente ${ }^{6}$. A maneira como entendemos a questão já está, de alguma forma, presente no título desta dissertação.

Por meio do estudo da evolução urbana de São José dos Campos, assunto do Capítulo 2, podemos observar que as atitudes e os programas adotados pelo poder

\footnotetext{
${ }^{6}$ Ainda que muito se explique pelo modo de produção e pelo presente estágio de globalização financeira e neoliberalismo, não nos pareceu adequado deixar de lado as peculiaridades do município.
} 
público enfocam, exclusivamente, o crescimento econômico e a formação do pólo regional do Vale do Paraíba.

Castells (2003) afirma que a metrópole é expressão e não reflexo do modo de produção da sociedade. Assim sendo, a metrópole pode ser vista como um poderoso agente das transformações que nela se organizam, no âmbito da nova etapa do sistema produtivo, e não como pura conseqüência lógica e passiva desse desenvolvimento.

É necessário identificar o perfil das atuais dinâmicas urbanas que estão ocorrendo, no território do aglomerado do Vale do Paraíba, com o objetivo de elaborar pautas para as políticas públicas e projetos de intervenção eficazes para o enfrentamento das significativas demandas sociais acumuladas, decorrentes do desenvolvimento econômico, e do padrão de urbanização resultante da legislação.

Para Meyer, Grostein \& Biderman (2004), uma das inúmeras definições de metrópole sustenta que, do ponto de vista estritamente funcional, ela é uma congregação de unidades administrativas autônomas que apresentam problemas urbanos comuns. Para esses autores, e concordando com eles, "a metrópole é, acima de tudo, a expressão de um processo de articulação e não de desarticulação do território urbanizado, sendo esse atributo que as distingue das demais formas de organização territorial".

Segundo os autores, desde os anos 70 , as palavras-chave utilizadas para descrever física e funcionalmente a nova organização metropolitana, quando esse fenômeno se tornou patente, são fragmentação e dispersão. Essas duas palavras atestam a presença de uma característica específica do território metropolitano contemporâneo que consiste em romper as continuidades urbanas tradicionais e gerar núcleos de atividades, descritos como desagregados do ponto de vista urbano, e difusos do ponto de vista funcional.

Para Meyer, Grostein \& Biderman (2004), tanto o primeiro, qualitativo, quanto o segundo podem ser equivocados, pois a sua percepção está baseada em formas já 
superadas de continuidade física, isto é, formas de organização relacionadas com o modelo em processo de superação.

\begin{abstract}
Os dois atributos - fragmentação e dispersão - não apenas passaram a representar um novo arranjo do território como também ganharam, simultaneamente, a condição de experiências espaciais, territoriais e até existenciais sintonizadas com as mudanças, e o que é mais grave, perderam até mesmo seu significado original. (MEYER, GROSTEIN \& BIDERMAN, 2004).
\end{abstract}

São José dos Campos é sede de um aglomerado que dá sustentação à metrópole de São Paulo. Esse aglomerado formou-se, seja por fragmentação ou dispersão, da metrópole maior. As cidades de Jacareí, São José dos Campos, Caçapava, Taubaté e Pindamonhangaba estão conurbadas ao longo da Rodovia Dutra.

Segundo Reis Filho (2006), as mudanças que estão ocorrendo no processo de urbanização da região do Alto Vale do Paraíba, são decorrentes da formação de áreas de urbanização dispersas. Ao observarmos as cidades que formam esse aglomerado, identificamos nessa micro-região fatores que, segundo Reis Filho são relacionados às conseqüências do acelerado processo de urbanização que essas cidades vivenciam.

1) esse aglomerado que, apesar de ser separado no espaço por meio de perímetros ou por acidentes naturais geográficos, mantêm entre si, estreitos vínculos;

2) identifica-se também a adoção de modos metropolitanos de vida e de consumo pela população.

No Vale do Paraíba, a urbanização se desenvolveu ao longo de todo o eixo da Via Dutra, sendo que o trecho mais condensado situa-se entre as cidades de Jacareí e Pindamonhangaba, com cerca de $90 \mathrm{~km}$ de comprimento e entre 10 a $20 \mathrm{~km}$ de largura. Os dois centros maiores, São José dos Campos e Taubaté, polarizam a região.

Nesses municípios, como em outras cidades do Vale do Paraíba, o urbano já não se concentra apenas no interior das cidades. As fábricas, o comércio, os serviços 
locais e de entretenimento e lazer e, recentemente, no caso de São José dos Campos, algumas universidades e condomínios de alto padrão estão dispostos ao longo Rodovia Dutra. As áreas residenciais tendem a se localizar próximas ao entroncamento dos principais eixos rodoviários ou em suas margens, em locais de fácil acesso ou passagem obrigatória. No Vale do Paraíba, há um longo eixo de urbanização.

Em alguns casos, o conceito de urbanização dispersa, no conjunto de cidades médias como o Vale do Paraíba, passou a se organizar de modo integrado, como uma área metropolitana, embora não assumida pelas administrações desses municípios. A existência da dispersão urbana é resultado da descentralização industrial e também de uma intensa mobilidade da população dessa região.

Na opinião de Reis Filho (2006), esse processo é muito mais amplo e complexo do que se poderia supor e, com tais características, dificilmente será um processo reversível. Os novos padrões correspondem a mudanças permanentes. A cidade tradicional, de tecido contínuo e com limites razoavelmente definidos, já não pode mais ser considerada regra.

De acordo com Choay (1999) e a partir dos estudos realizados para a elaboração desta pesquisa, podemos afirmar "que chegou então o momento de admitir, sem sentimentalismos o desaparecimento da cidade tradicional".

A partir do reconhecimento desta mudança, ou seja, que a parte faz parte de um todo complexo pela administração de cada cidade que compõe o aglomerado do Alto Vale do Paraíba, os correspondentes poderes locais abandonaram suas políticas independentes e houve pleno desenvolvimento da região; caso contrário, a pulverização dos controles políticos seguindo interesses menores, sem qualquer visão de conjunto, podem trazer maiores problemas intra-urbanos para cada município, além de um problema maior que é a falta de desenvolvimento regional pleno.

Como observa Flávio Villaça (1999) "no intra-urbano estamos no âmbito do consumo; no regional estamos no âmbito da produção". 
Os padrões correntes de controle do Estado (em todos os seus níveis) sobre o espaço urbano e sobre as práticas de sua produção e gestão estão se tornando obsoletos e a busca de alternativas para o enfrentamento desta questão, em termos de políticas públicas, faz-se necessária. Ao admitirmos que a cidade tradicional de algum modo desapareceu, o que podemos dizer então das atuais políticas públicas que vêm sendo praticadas nas administrações dessas cidades?

Deve-se considerar a afirmação de Villaça (2005), quando opina que "os planos diretores desenvolvidos nas prefeituras dos municípios do Brasil não possuem força política e não passam de um cardápio para os prefeitos, principalmente, quando recém-eleitos".

Cada vez mais fica claro que é preciso aprofundar esta análise e realizar estudos mais detalhados para o enfrentamento que deve ser adotado pelas administrações municipais para as mudanças que vêm ocorrendo rapidamente nos últimos anos.

\subsection{O Vale do Paraíba}

A região do Vale do Paraíba situa-se a Leste do Estado de São Paulo e se caracteriza como uma das mais antigas áreas de povoamento e importante ponto de passagem dos Bandeirantes entre São Paulo, Rio de Janeiro e Minas Gerais no ciclo do ouro. A região é compreendida pela bacia hidrográfica do Rio Paraíba do Sul e começou a ser povoada a partir do início de 1600.

A Vila de São Francisco das Chagas de Taubaté foi o primeiro núcleo urbano do Vale do Paraíba, em 1645, quando passou a ser ponto de partida de sertanistas regionais e colonizadores das terras vizinhas. No século XVII, o Vale do Paraíba começa o seu processo mais intenso de urbanização e a população se concentrava no vale do rio, por ser ali o território mais fértil para a agricultura. 
Nas primeiras décadas do século XVIII, o Vale do Paraíba assiste à intensificação do povoamento e o crescimento de sua economia em função das Minas Gerais. No entanto, após o declínio da mineração, a região iniciou a cultura da cana de açúcar e muitos engenhos foram instalados em Guaratinguetá, Lorena e Pindamonhangaba.

No final do século XVIII, a cultura do café chega à região, e o município de Sant'Anna de Areias foi o pioneiro na produção intensiva do café no Estado. Neste período, a região do Vale do Paraíba era um dos mais importantes centros políticos e econômicos do Brasil Império.

Porém, em 1920, o ciclo do café se encerra no Vale do Paraíba dando início à industrialização. Esse processo foi acelerado com a implantação da Estrada de Ferro Central do Brasil - EFCB e pela abertura da ligação rodoviária entre São Paulo e Rio de Janeiro em 1928.

As primeiras indústrias surgiram na região nas últimas décadas do século XIX, quando se colocou o desafio de novas opções decorrentes da Abolição da Escravatura, da disponibilidade de capital e da melhoria do nível de consumo.

Verificamos que dois aspectos foram marcantes para o início da industrialização na região do Vale do Paraíba:

1) a situação geográfica entre os dois maiores centros produtores e consumidores do país - São Paulo e Rio de Janeiro;

2) a facilidade de transporte e comunicação; disponibilidade de recursos hídricos e energéticos.

O marco do processo mais intenso de urbanização ocorreu após a implantação da Siderúrgica Nacional em Volta Redonda, Estado do Rio de Janeiro, e a inauguração da Rodovia Presidente Dutra, em 1950. 
De acordo com dados da Fundação SEADE (1988), até a década de 1960 o Vale do Paraíba respondia a 2,0\% do valor da produção industrial do Estado. A partir daí, a região cresceu para 3,0\% em 1970; 4,6\% em 1975 e 5,9\% em 1980. O pólo formado no aglomerado do Alto Vale do Paraíba é composto pelas cidades de Jacareí, São José dos Campos, Caçapava, Taubaté, Tremembé e Pindamonhangaba. Atualmente, o pólo central é o município de São José dos Campos.

São José dos Campos localiza-se no Estado de São Paulo, Vale do Paraíba, possui uma área de 1.099,66 km² e uma população estimada pelo IBGE, para 2007, de 629.346 habitantes.

No decorrer das pesquisas realizadas para a elaboração deste estudo, verificamos que o município possui características peculiares. É o único, entre os outros pólos regionais do Estado, que não esteve ligado ao Complexo Cafeeiro, portanto uma cidade que, no século XIX e início do XX, não tinha expressão no Vale do Paraíba. Este é um fenômeno que encontra pouco paralelo no Estado de São Paulo, na medida em que a Rede Urbana Paulista carrega uma influência marcante da expansão cafeeira, ocorrida no marco da transição ao trabalho assalariado, ou já em plena economia cafeeira capitalista, centrada, portanto, a Oeste de seu território, na capital e no porto de Santos.

Por não se caracterizar - a exemplo de Campinas, Santos, Ribeirão Preto, Sorocaba - como um centro regional, ainda no período cafeeiro, São José dos Campos herdou uma economia urbana de dimensões restritas e de pequena inserção regional. Assiste-se, nesse município, um processo particular de organização de um centro regional, cujos determinantes estão quase que exclusivamente assentados sobre o crescimento urbano-industrial que se disseminaria pelo entorno da capital, a partir dos anos 50 .

No início dos anos 30, São José dos Campos já passava por uma profunda transformação intra-urbana e, por força do Decreto Estadual $n^{0} 7.007$, de 12 de março de 
1935, a cidade foi elevada à condição de Estância Climática e Hidromineral ${ }^{7}$. Nesse decreto, as receitas da Estância seriam constituídas pelas arrecadações municipais destinadas à manutenção administrativa e as receitas oriundas da arrecadação estadual seriam aplicadas em serviços públicos.

Essa disposição teve o objetivo de prover a prefeitura dos recursos necessários à execução dos grandes melhoramentos exigidos pela Estância, delineados no artigo $3^{\circ}$ do referido decreto, tais como: água, esgotos, iluminação, pavimentação, praças, jardins, bosques, estádios, zoneamento para residências, comércio, indústria e sanatórios, etc. (FLÓRIO, 1994 p.131).

São José dos Campos era uma das poucas cidades do Estado e do Brasil que possuía recursos financeiros no período da Segunda Guerra. A partir da década de 40, a cidade passou a ter obras urbanas significativas e um traçado pautado pela continuidade espacial, quadras regulares e vias amplas e ortogonais. Os detalhes referentes a este período são apresentados no Capítulo 3, item 3.1.

Ao analisarmos o Plano Regional Aspectos do Vale do Paraíba e de seu reerguimento no Governo Adhemar de Barros, datado de 1938, podemos encontrar as primeiras diretrizes que viriam reforçar a atual vocação econômica, tanto do Vale do Paraíba como de São José dos Campos.

\subsection{0 crescimento econômico do Vale do Paraíba}

Scott e Storper (1988, p.38) reforçam e afirmam que "muitos centros surgiram como grandes ímãs para vários tipos de indústria de alta tecnologia". Sustentam que aquilo que "em muitos casos pode ter começado com um evento locacional essencialmente arbitrário, dentro de um contexto macroespacial não arbitrário, com o

\footnotetext{
${ }^{7}$ O que torna significativa a condição de Estância Climática e Hidromineral que a cidade assume por decreto, dentre outros fatores, foi a possibilidade de dotação de verbas vindas do fundo de participação das Estâncias que possibilitaram não só ensaios de Plano Diretor de numerosas cidades, com o é o caso de São José dos Campos, mas também a urbanização, principalmente no setor de infra-estrutura de saneamento, em uma época como a depressão da Segunda Guerra Mundial quando os recursos eram escassos para a maioria das cidades.
} 
passar do tempo, se transformou em um foco auto-comprovável de crescimento e desenvolvimento".

Embora São José dos Campos já apresentasse, desde os anos 50 e 60, um expressivo desenvolvimento urbano, é na década de 70 que ocorreu expressivo crescimento, tanto no município como na região do médio Vale do Paraíba.

Para se ter uma idéia do desenvolvimento industrial em São José dos Campos, na década de 70, podemos verificar que as cidades vizinhas - Jacareí, Caçapava e Taubaté - possuíam 385 estabelecimentos industriais e empregavam 14,2 mil pessoas, enquanto que em São José dos Campos havia 275 estabelecimentos com 17,8 mil pessoas ocupadas. ${ }^{8}$

Sendo assim, podemos dizer que antes mesmo que a "interiorização da indústria" ganhasse uma dimensão maior na década de 70, os municípios do Alto Vale do Paraíba já sediavam alguns dos mais importantes estabelecimentos industriais do interior do Estado de São Paulo, segundo Negri (1988), e São José dos Campos já agregava, naquele período, características marcantes de ser o pólo central desse aglomerado.

Este desempenho da indústria também revela o que ocorreu com o conjunto da economia de São Paulo. As economias urbanas do interior do Estado apresentaram um crescimento acima da metrópole e da média nacional. Apenas a diferenciação e sofisticação do terciário metropolitano, estimulado pela própria economia do interior, fugiu a esta regra. De resto, foi nos centros médios e grandes do interior que este processo materializou-se numa urbanização acelerada.

Os números da tabela 1.1 revelam este processo de desconcentração industrial a partir de São Paulo: praticamente todas as regiões brasileiras ganham peso. Perdem Rio de Janeiro e São Paulo, sobretudo sua área metropolitana.

Entre 1970 e 1996 a participação do interior de São Paulo passa de 14,6\% para cerca de $23,2 \%$ do valor da transformação industrial do país.

\footnotetext{
${ }^{8}$ FIBGE. Censo Industrial de 1970.
} 
Tabela 1.1 - Distribuição Espacial do VTI da indústria de transformação Brasil, unidades da Federação e Regiões selecionadas - 1970 a 1996

\begin{tabular}{|c|c|c|c|c|c|c|}
\hline & 1970 & 1975 & 1980 & 1985 & 1990 & 1996 \\
\hline Nordeste & $5,7 \%$ & $6,3 \%$ & $7,5 \%$ & $8,6 \%$ & $8,3 \%$ & $8,0 \%$ \\
\hline Minas Gerais & $6,4 \%$ & $6,3 \%$ & $7,7 \%$ & $8,3 \%$ & $8,7 \%$ & $9,2 \%$ \\
\hline Rio de Janeiro & $15,6 \%$ & $13,5 \%$ & $10,2 \%$ & $9,5 \%$ & $9,8 \%$ & $8,4 \%$ \\
\hline São Paulo & $57,6 \%$ & $55,7 \%$ & $54,4 \%$ & $51,9 \%$ & $49,2 \%$ & $48,7 \%$ \\
\hline $\begin{array}{c}\text { Grande São } \\
\text { Paulo* }\end{array}$ & $43,0 \%$ & $38,7 \%$ & $34,1 \%$ & $29,4 \%$ & $28,4 \%$ & $25,6 \%$ \\
\hline $\begin{array}{c}\text { Interior São } \\
\text { Paulo* }\end{array}$ & $14,6 \%$ & $17,1 \%$ & $20,2 \%$ & $22,5 \%$ & $20,8 \%$ & $23,2 \%$ \\
\hline $\begin{array}{l}\text { Rio Grande do } \\
\text { Sul }\end{array}$ & $6,3 \%$ & $7,6 \%$ & $7,7 \%$ & $7,9 \%$ & $7,7 \%$ & $7,9 \%$ \\
\hline Paraná & $3,0 \%$ & $4,0 \%$ & $4,1 \%$ & $4,9 \%$ & $5,7 \%$ & $5,6 \%$ \\
\hline Outra regiões(**) & $2,6 \%$ & $3,3 \%$ & $4,5 \%$ & $5,1 \%$ & $6,4 \%$ & $7,7 \%$ \\
\hline
\end{tabular}

Fonte:FIBGE, Censos Industriais de 1970, 1975, 1980, 1985: FIBGE, PIM/PF de 1986 a 1996; Secretaria da Fazenda de São Paulo, 1996 a 1995. Obs.: (*) Participação no VTI de 1986 a 1996 estimada a partir do Valor Adicionado Fiscal de cada ano; distribuição de 1996 segundo participação de 1995. (**) A partir de 1996 resíduo da diferença Brasil menos Sul, Nordeste, minas Gerais, Rio de Janeiro e São Paulo.

Em São José dos Campos e nos municípios vizinhos, este desempenho da economia do interior fez-se presente, principalmente, pela diversificação e crescimento da indústria. Algumas novas e grandes unidades produtivas instalaram-se na região, com destaque para uma refinaria da Petrobrás e duas montadoras de veículo.

Específico, frente ao restante do interior, o fato de que este processo independeu da evolução da base agrícola regional. A frágil agricultura do Vale do Paraíba não acompanhou o desempenho industrial, ainda que tenha acelerado, em parte, sua feição anterior.

O terciário, por sua vez, cresceu e diferenciou-se também de forma acelerada, mesmo condicionada à proximidade da capital, ao menos até o agravamento da crise da indústria local, cujo ponto crítico foi o início dos anos 90, o crescimento do emprego e o aumento populacional impulsionavam as atividades terciárias. Na década de 
80, este processo serviu, inclusive, para reduzir a assimetria que se acumulou nos anos anteriores, em razão do crescimento acelerado da atividade industrial.

As cidades ganharam outras dimensões. Multiplicaram-se as interdependências e São José dos Campos assumiu definitivamente as características de um centro regional. Uma conurbação embrionária, a partir da Via Dutra, passou a definir um aglomerado urbano de grandes proporções, embora relativamente difuso. Mais relevante ainda, contudo, é o adensamento desta rede de cidades e a natureza articulada de seu crescimento.

Em termos regionais, os anos 70 foram marcados por uma expressiva expansão da base industrial do Alto Vale do Paraíba. Em São José dos Campos e Taubaté o número de pessoas ocupadas na indústria multiplicou-se por 2,3; em Jacareí por 1,7 e em Caçapava por 2,4.

Mais significativo que isto é o fato desse crescimento ter se concentrado em grandes plantas industriais dos segmentos de material de transporte, mecânica e química. A estrutura industrial moveu-se em direção aos setores de bens intermediários, de capital e de consumo duráveis, reduzindo ainda mais o peso dos bens de consumo não duráveis.

Nessa mesma década, o crescimento da indústria também pode ser dimensionado pelo valor da transformação industrial. Entre 1970 e 1980, a taxa de crescimento do valor da transformação industrial de São José dos Campos atingiu 15,3\% a.a. O volume do emprego industrial, medido pelo censo de estabelecimentos, passa, no mesmo período, de 17.786 para 41.432 empregados, com uma taxa significativamente mais alta que o crescimento da população urbana do mesmo período. Em síntese, o desempenho industrial da região assegurou taxas de crescimento muito superiores às verificadas para o conjunto do Estado.

Desde 1970, este processo tem acarretado o aumento da participação do Vale do Paraíba no total do produto industrial de São Paulo. Assim, entre 1970 e 1980, a 
participação no VTI estadual (valor da transformação industrial, segundo os censos industriais da FIBGE) passou de 3,3\% para 5,5\%. Entre 1980 e 1995, medida pelo valor adicionado (Secretaria da Fazenda), esta participação continuou ampliando-se: de 5,5\% para $8,8 \%$. Dentre as regiões mais industrializadas do Estado, este foi o melhor desempenho relativo superando, inclusive, a variação do valor adicionado da região administrativa de Campinas.

O principal fator indutor desse crescimento rumo ao interior foi de origem extralocal, e é nessa década que também teve início o processo mais intenso de desconcentração industrial da grande São Paulo.

A consolidação de infra-estrutura viária rumo ao interior, juntamente com as transformações estruturais da economia e os fatores ligados à deseconomia de aglomeração, presentes na metrópole paulista, impulsionaram o processo de descentralização relativa das atividades industriais concentradas na Grande São Paulo.

Portanto, no interior estavam as bases do crescimento urbano que transformariam estes municípios num dos aglomerados mais importantes do país e que daria à indústria regional um porte mais significativo.

A região de São José dos Campos foi um dos eixos dessa desconcentração industrial, atraindo um grande volume de indústrias, isto devido, entre outros, aos seguintes fatores:

a) a estratégica proximidade à cidade de São Paulo;

b) facilidade de acesso pela via Dutra;

c) instalação de distritos industriais e pólos tecnológicos;

d) oferta de mão-de-obra qualificada;

e) política de incentivos fiscais.

Segundo Negri (1988), do ponto de vista espacial, na década de 70, o Estado de São Paulo perde peso relativo para o restante da indústria nacional, mas por outro lado, aprofunda-se em um rápido processo de interiorização da indústria em São Paulo. 
Segundo Cano et all (1988), nas décadas de 70 e 80, cada uma a seu modo, marcam um processo de diferenciação da economia do Estado de São Paulo, chamado de "interiorização do desenvolvimento". Durante estes anos, a economia do interior de São Paulo cresceu quase sistematicamente acima daquela situada na área metropolitana, seja pelos desdobramentos de sua base agrícola, seja, principalmente, pelo desempenho favorável da atividade industrial do interior.

Os primeiros dez anos foram de extraordinário crescimento e parte significativa do aumento de capacidade produtiva da indústria paulista, então verificado, localizou-se no interior.

Na década de 80, o crescimento industrial paulista continuou dependendo da expansão para o interior, em particular, das regiões mais favorecidas pela política de exportação e de maior peso das agroindústrias, além das regiões favorecidas pela implantação de indústrias de material bélico, de transportes, tecidos, calçados, produtos siderúrgicos, mecânicos e caldeiraria.

O movimento de interiorização da indústria prosseguiu por toda década de 80 e, a partir daí, a centralização do capital se acentuou, aprofundando o caráter desigual do desenvolvimento brasileiro e, o fortalecimento de tais processos na industrialização recente, significou o revigoramento da tendência à concentração espacial da produção industrial.

Em São Paulo esta concentração foi reforçada num raio de 150 km da capital paulista e, indo além desta distância, na direção das principais vias de transporte. Os principais determinantes do processo de interiorização da indústria do Estado de São Paulo estiveram relacionados diretamente aos itens a seguir relacionados:

1) políticas restritivas à área metropolitana por intermédio de diferentes leis, criaram um aparato institucional de âmbito federal e estadual relativo à proteção ambiental, ao parcelamento do solo, ao zoneamento industrial e à proteção dos mananciais das áreas metropolitanas. Com o passar do tempo, 
essas leis foram sendo modificadas e aperfeiçoadas, constituindo-se como fator inibidor da ampliação das fábricas de novas unidades industriais;

2) políticas de interiorização, estimuladas pelo governo federal. O governo estadual adotou uma série de planos e programas visando ao desenvolvimento urbano e regional de São Paulo, como o Programa de Cidades Médias, Programa de Interiorização de Desenvolvimento PROINDE, Política de Desconcentração Industrial e Programa do Macro-Eixo Rio São Paulo;

3) crescimento das exportações de manufaturados, com aumento da diversificação das exportações de produtos manufaturados, material de transporte, material bélico e aeronáutico, máquinas e equipamentos e aumento das exportações de insumos básicos - aço, papel e papelão, acentua-se a indústria do interior produtora de bens. Consolida-se o parque produtor de material bélico, aeronáutico e de transporte da região de São José dos Campos;

4) investimentos estatais no setor produtivo e no desenvolvimento da ciência e da tecnologia. Na esfera do investimento do setor produtivo estatal, devemos mencionar a implantação do Centro Tecnológico da Aeronáutica CTA (1950) e da Embraer (1969), prioridades do Ministério da Aeronáutica para a produção de aviões.

Em função da política de descentralização industrial a partir de São Paulo, desde o período de 1970, o governo federal foi obrigado a sucumbir à lógica capitalista espacial e realizar uma série de investimentos no setor produtivo estatal em São Paulo que reforçou o processo de interiorização. Em 1980, o governo federal, pela dimensão da economia paulista, instalou a Refinaria Henrique Lage em São José dos Campos ampliou a participação relativa da indústria química na estrutura setorial regional. 
5) deseconomias de aglomerações entre seus principais itens, tem-se o sistema de abastecimento de transporte de carga e de passageiros, incluindose a infra-estrutura viária, o sistema de abastecimento de água e de coleta de esgoto, entre outros. O conjunto desses fatores leva muitos empresários a buscarem alternativas locacionais, em especial a novos investimentos e ampliação de suas unidades industriais, optando por núcleos urbanos.

Em São José dos Campos e nos municípios vizinhos, o desempenho da economia do interior fez-se presente, sobretudo pela diversificação e crescimento da indústria. Em relação ao restante do interior, o fato é que o processo que ocorreu em São José dos Campos e região, independeu da evolução da base agrícola regional.

São José dos Campos dispõe, atualmente, de um setor terciário significativo na região que impulsiona o processo de metropolização, fato este que também se consubstancia no processo de conurbação dos aglomerados urbanos ao longo da Via Dutra.

Os municípios vizinhos de São José dos Campos, além de sediar importantes indústrias, passaram a empregar mão-de-obra de outras regiões atraindo grande movimento migratório, portanto, adquiriram características metropolitanas, tanto do ponto de vista econômico como demográfico.

São José dos Campos é, hoje, sede de um dos mais importantes aglomerados da rede urbana paulista, mas como pouco se fez em termos de planejamento urbano, esses problemas agravaram-se nos maiores centros que foram afetados pelo processo de urbanização.

Segundo Lencioni (1994) e concordando com a autora, “(..) novas rehierarquizações urbanas no interior da região da metrópole desconcentrada se impõe."

Os problemas antes concentrados na Grande São Paulo foram, gradativamente, transferidos para as cidades médias do interior, contribuindo para o agravamento da condição de vida precária de parte da população. 
A expansão urbana do Vale do Paraíba foi direcionada, principalmente, por dois fatores que incluem fortes componentes extralocais como projetos e investimentos estaduais e federais:

1) Abertura de grandes eixos viários e a instalação industrial.

A Rodovia Presidente Dutra foi inaugurada em 1951 e causou grande impacto no município de São José dos Campos, pois os novos loteamentos que surgiam, na década de 50, não se detiveram nas proximidades do núcleo urbano; atingiram locais distantes, tomando a direção da Via Dutra, onde as novas indústrias se instalavam.

Assim, criou-se uma verdadeira faixa industrializada, intercalada por loteamentos residenciais, sem qualquer infra-estrutura. Além disso, muitas vezes invadia áreas produtivas da Zona Rural de maneira esparsa e descontínua.

Por este motivo, foi celebrado um convênio com o Centro de Estudos Urbanísticos da Universidade de São Paulo, em 1958, com o objetivo específico de limitar as áreas passíveis de serem loteadas. Um Plano Preliminar foi elaborado por esse centro de estudos, datado de 1961.

Essa diretriz teve a intenção de disciplinar a implantação de loteamentos no município e esses seriam permitidos somente na Zona Urbana. Para tanto, foi criada uma legislação específica que limitava essas áreas e permitia o parcelamento na Zona Rural do município desde que a gleba possuísse área mínima de 0,5 ha. "Em 1970, as áreas urbanizadas dos municípios de Jacareí, São José dos Campos, Caçapava, Taubaté e Pindamonhangaba já estavam unidas pela Rodovia Dutra, a antiga estrada Rio - São Paulo e a Estrada de Ferro Central do Brasil“". (REIS FILHO, 2006).

Naquele período, São José dos Campos já apresentava a maior extensão de ocupação junto à Dutra e seus moradores a utilizavam como via local para acesso à Zona Sul.

O desenvolvimento industrial ao longo da Dutra estava definido e as áreas lindeiras à rodovia foram intensamente ocupadas, principalmente, no período entre 1970 - 
1986. Nesse período, segundo Reis Filho (2006) define-se o adensamento das áreas centrais e expansão periférica de núcleos dispersos nos municípios maiores ao longo do eixo viário - Rodovia Presidente Dutra, figura 1.1.

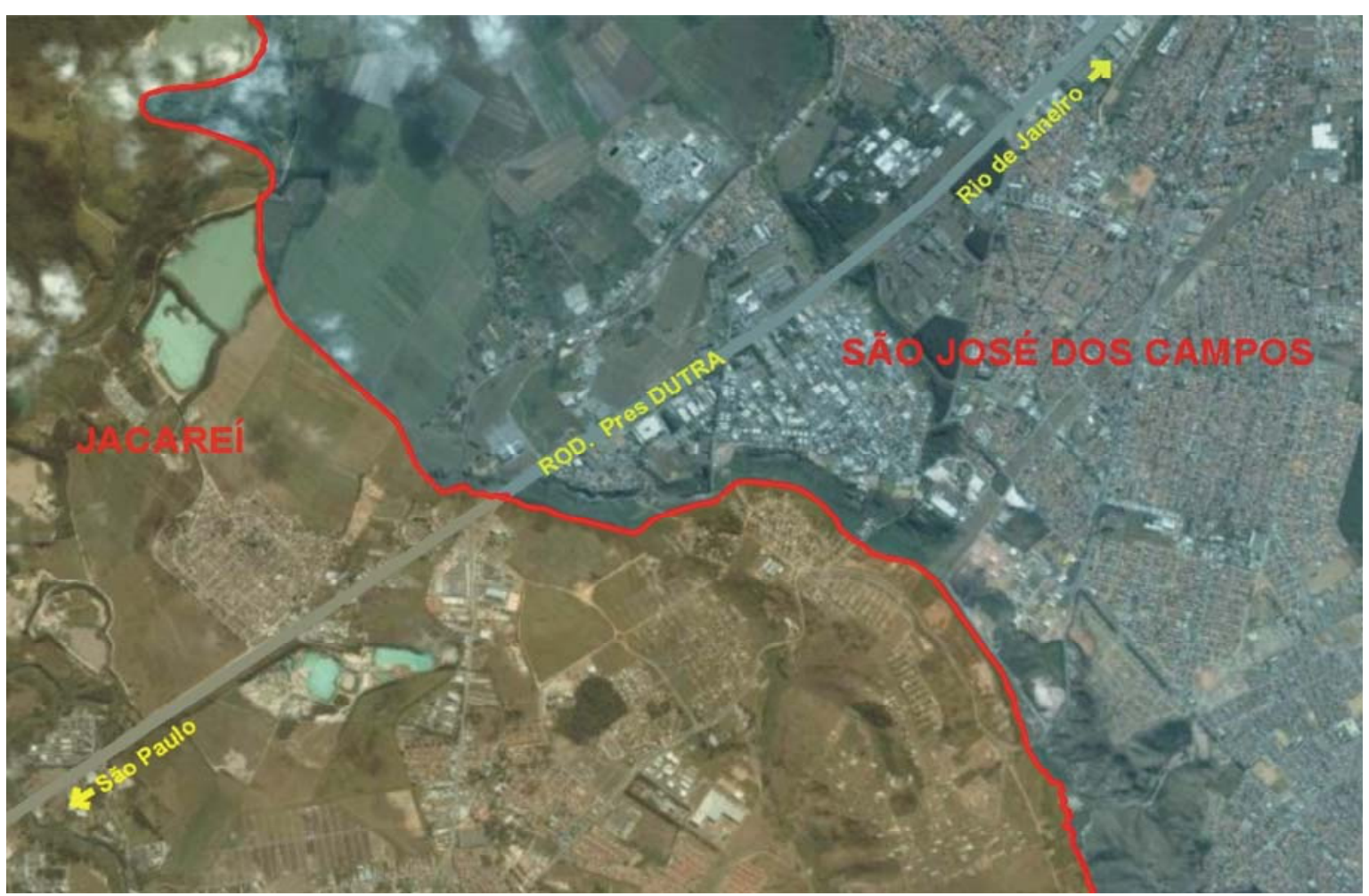

Figura 1.1 - Eixo viário e limite entre São José dos Campos e Jacareí Fonte: Google, 2006. 


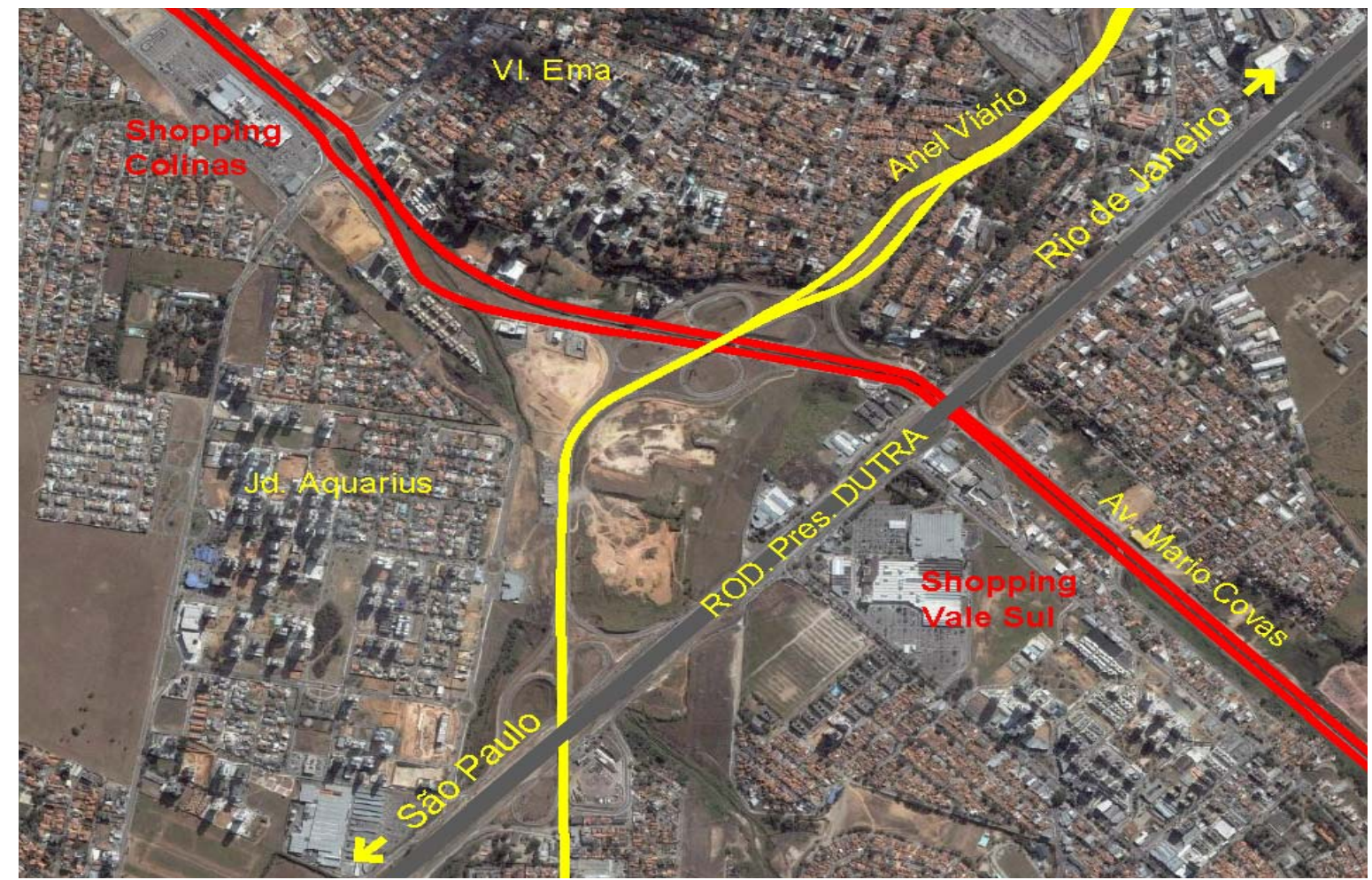

Figura 1.2 - Rodovia Dutra e Anel Viário Municipal Fonte: Google, 2006

Atualmente, observa-se que a Rodovia Presidente Dutra, fig. 1.2, apresenta vias marginais locais em um pequeno trecho de São José dos Campos, com uma grande Zona Urbana praticamente conurbada, que acompanha todo seu eixo. Esta conurbação se apresenta não só no trecho de São José dos Campos, mas de Jacareí até Pindamonhangaba. Nos limites dos perímetros urbanos desses municípios, as zonas conurbadas são formadas pelo encontro das periferias dessas cidades. 


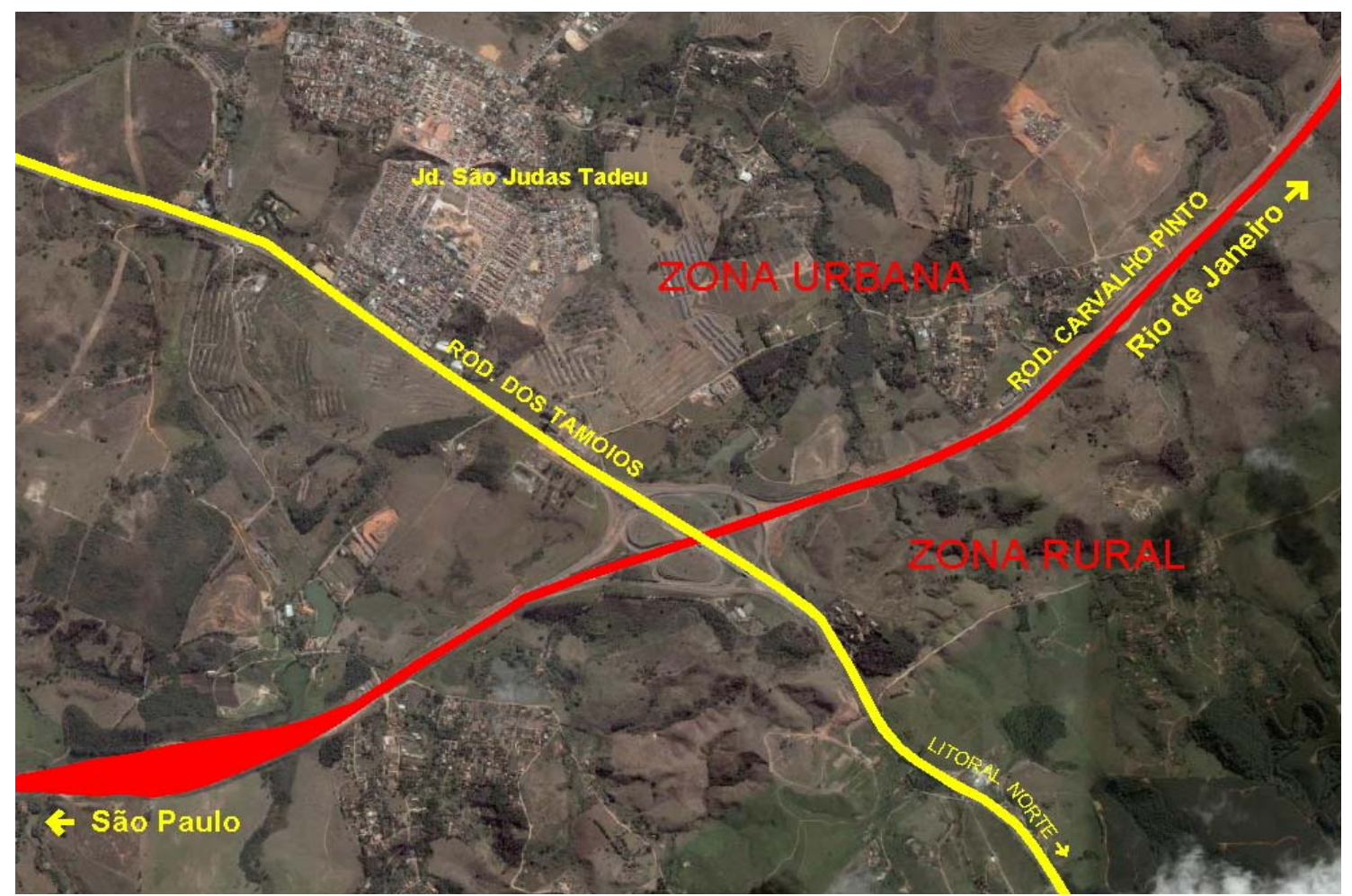

Figura 1.3 - Rodovia Carvalho Pinto e Rodovia dos Tamoios Fonte: Google, 2006

A Rodovia Carvalho Pinto é mais recente e representa um vetor de urbanização paralelo à Via Dutra, mas, por tratar-se de via expressa, não possui acesso direto, somente os pré-determinados em projeto. São José dos Campos possui um único acesso localizado no entroncamento com a Rodovia dos Tamoios, próximo ao Cadeião do Putim e a FEBEM. (fig. 1.3)

Atualmente, o espaço urbano entre as Rodovias Carvalho Pinto e Presidente Dutra caracteriza-se pelo aumento do número de núcleos dispersos, loteamentos clandestinos ou irregulares, esparsos e com grandes vazios entre eles, o que gerou uma malha urbana descontínua e desordenada implantada e atraída pelo solo barato na faixa entre as citadas rodovias. 


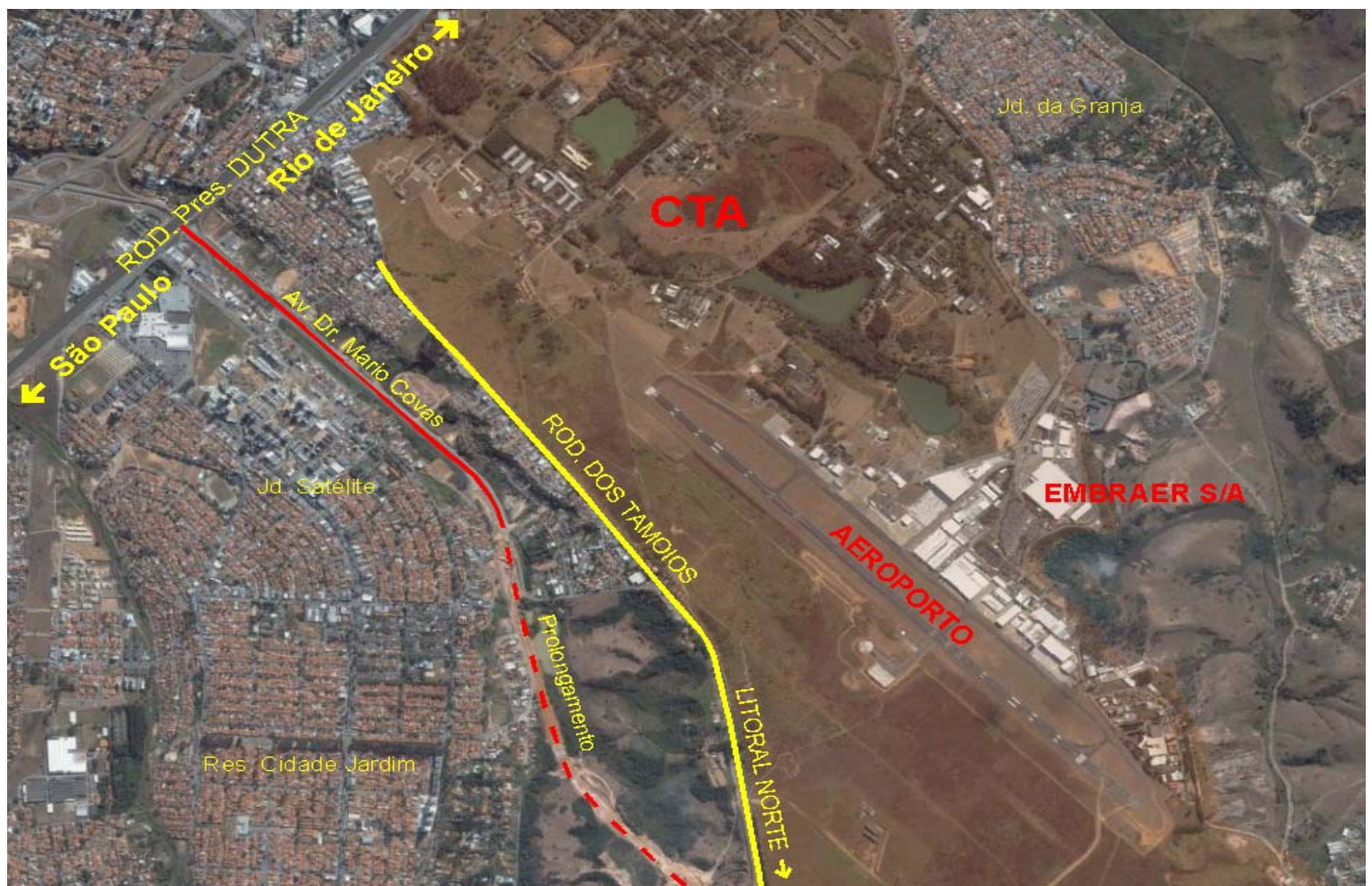

Figura 1.4 - Trecho urbano da Rodovia dos Tamoios (SP-99) que dá acesso ao Litoral Norte Fonte: Google Earth, 2006.

Em relação à Rodovia dos Tamoios, fig. 1.4, no trecho urbano de São José dos Campos, não trouxe grande ocupação, pois por um lado tangencia uma das faces da área de 12 milhões de $\mathrm{m}^{2}$, propriedade do Ministério da Aeronáutica destinada ao Centro Técnico Aeroespacial- CTA e no outro há uma faixa de loteamentos que não se expandiu devido a existência de barreiras geográficas. 


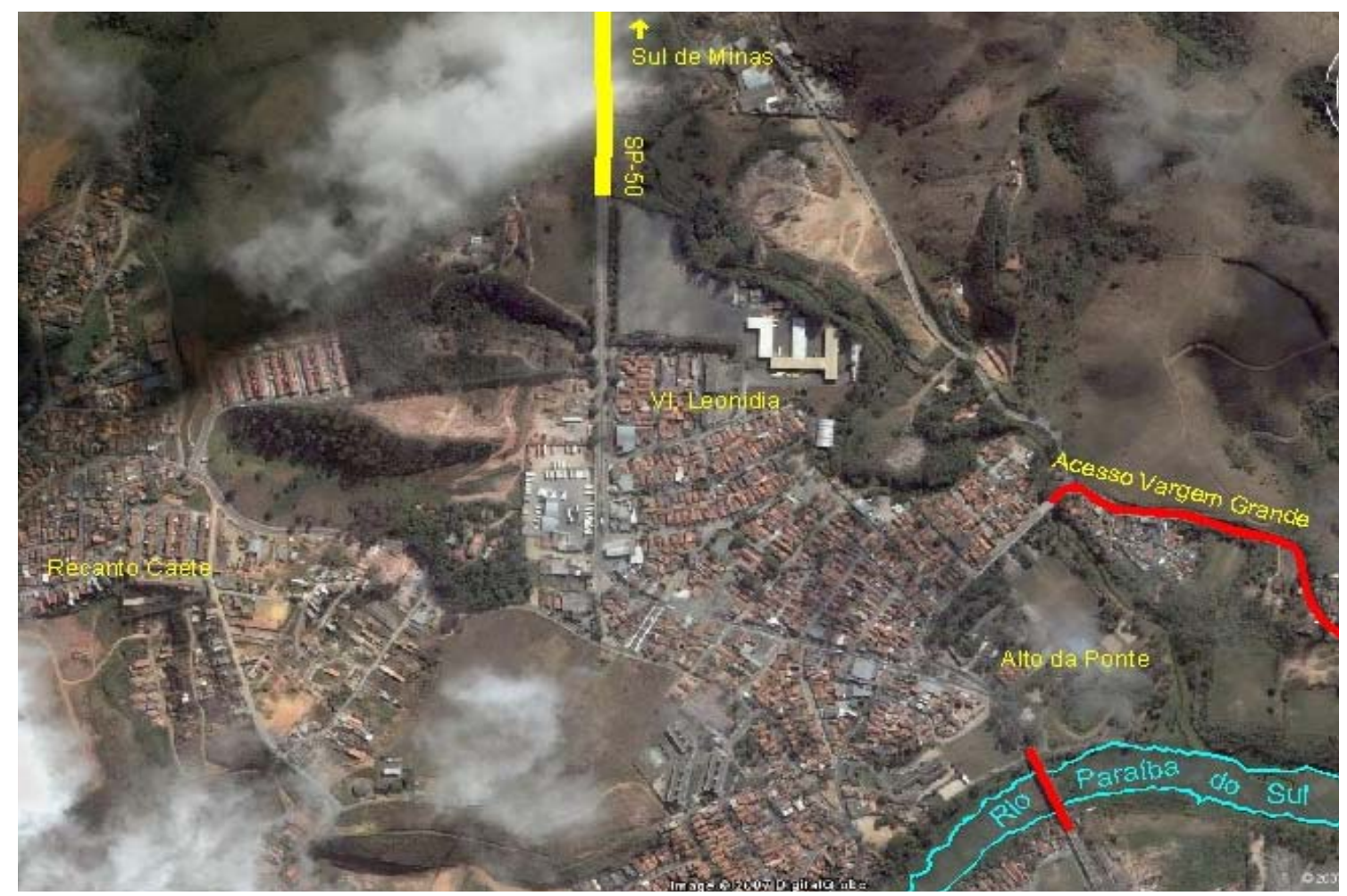

Figura 1.5 - Região Norte e Rodovia SP-50 acesso ao Sul de Minas Fonte: Google, 2006.

Na Região Norte, fig. 1.5, a expansão urbana ocorreu ao longo do eixo da Rodovia SP-50, antiga ligação para Campos do Jordão; hoje o acesso é feito por Taubaté.

Em São José dos Campos, a tendência de crescimento detectada em 1970, se acentua ao Norte e afunila na direção dos bairros periféricos ao longo da Rodovia SP50, ligação com Monteiro Lobato, Campos do Jordão e Sul de Minas. Devido ao baixo preço da terra e das barreiras físicas (Serra da Mantiqueira) a Região Norte de São José dos Campos possui inúmeros loteamentos irregulares e ocupação clandestina.

A partir de 1984, começaram a surgir na Zona Norte (rural), diversos loteamentos clandestinos sem qualquer infra-estrutura. Este processo de ocupação irregular foi intensificado nos anos subseqüentes, culminando em 1988 com, aproximadamente, 90 loteamentos.

Observou-se também que a atual configuração da cidade não foi adequadamente acompanhada pela ação do poder público local, principalmente a partir 
da década de 80 , em função da descontinuidade administrativa ocorrida no período, da falta de fiscalização e da ausência de uma política para habitação popular. Em função desse processo descontínuo, as ações de planejamento passaram a ter um papel mitigador.

Segundo Reis Filho (2006), no período entre 1970-1986 cresceu o número de núcleos dispersos em direção aos bairros situados próximos à Rodovia SP-50 (antiga estrada para Campos do Jordão).

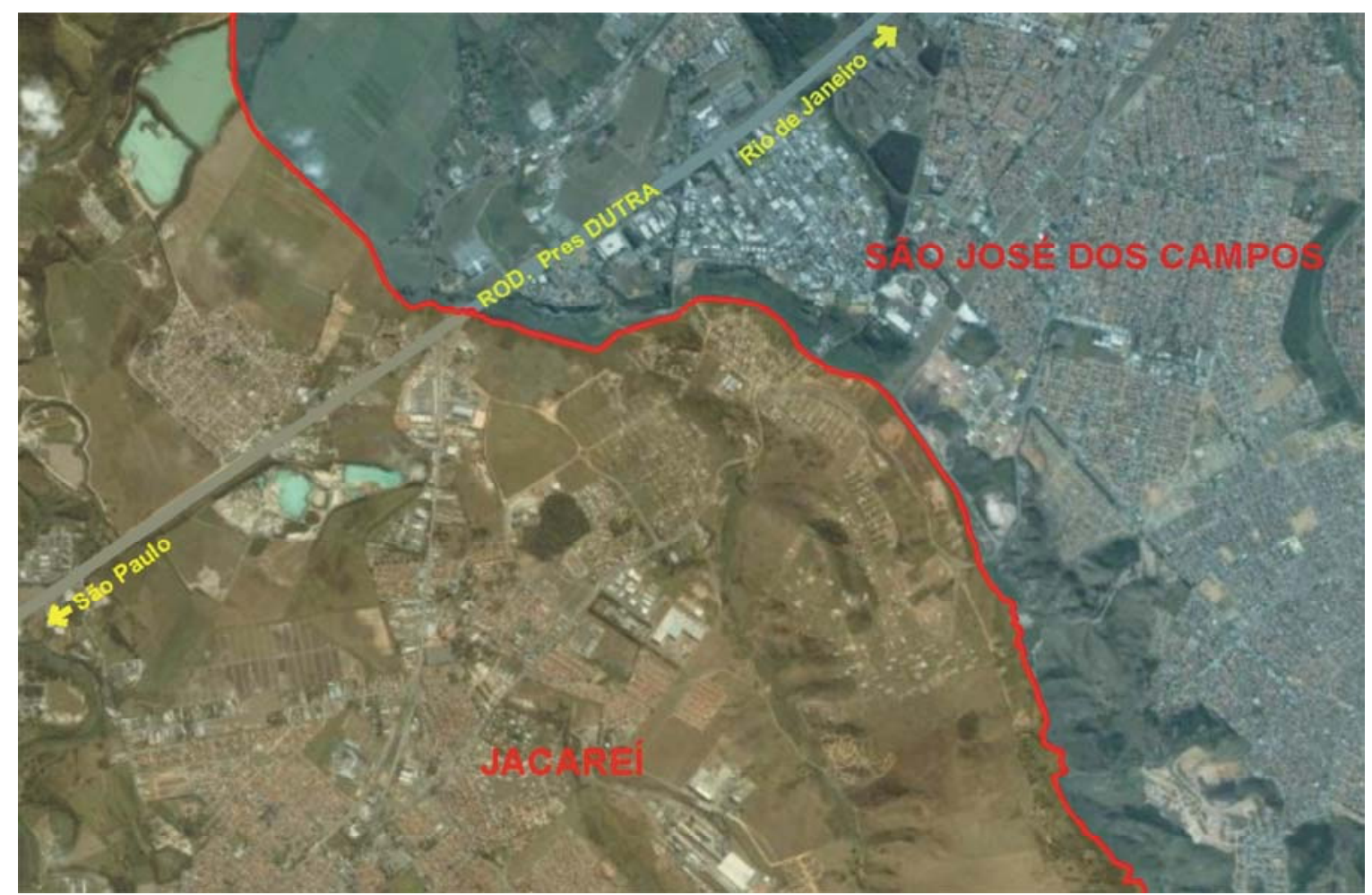

Figura 1.6 - Limite Oeste de São José dos Campos conurbado com Jacareí Fonte: Google, 2006.

Nos limites a Oeste de São José dos Campos, fig. 1.6, os núcleos dispersos vêm avançando em direção Leste de Jacareí, desde o início dos anos 70 e consolida o crescimento desses núcleos nos dois sentidos, facilitado pela implantação de vias de ligação interna com a Rodovia Dutra.

O mesmo processo de crescimento em direção aos municípios vizinhos verifica-se em Caçapava-São José dos Campos. fig. 1.7. 


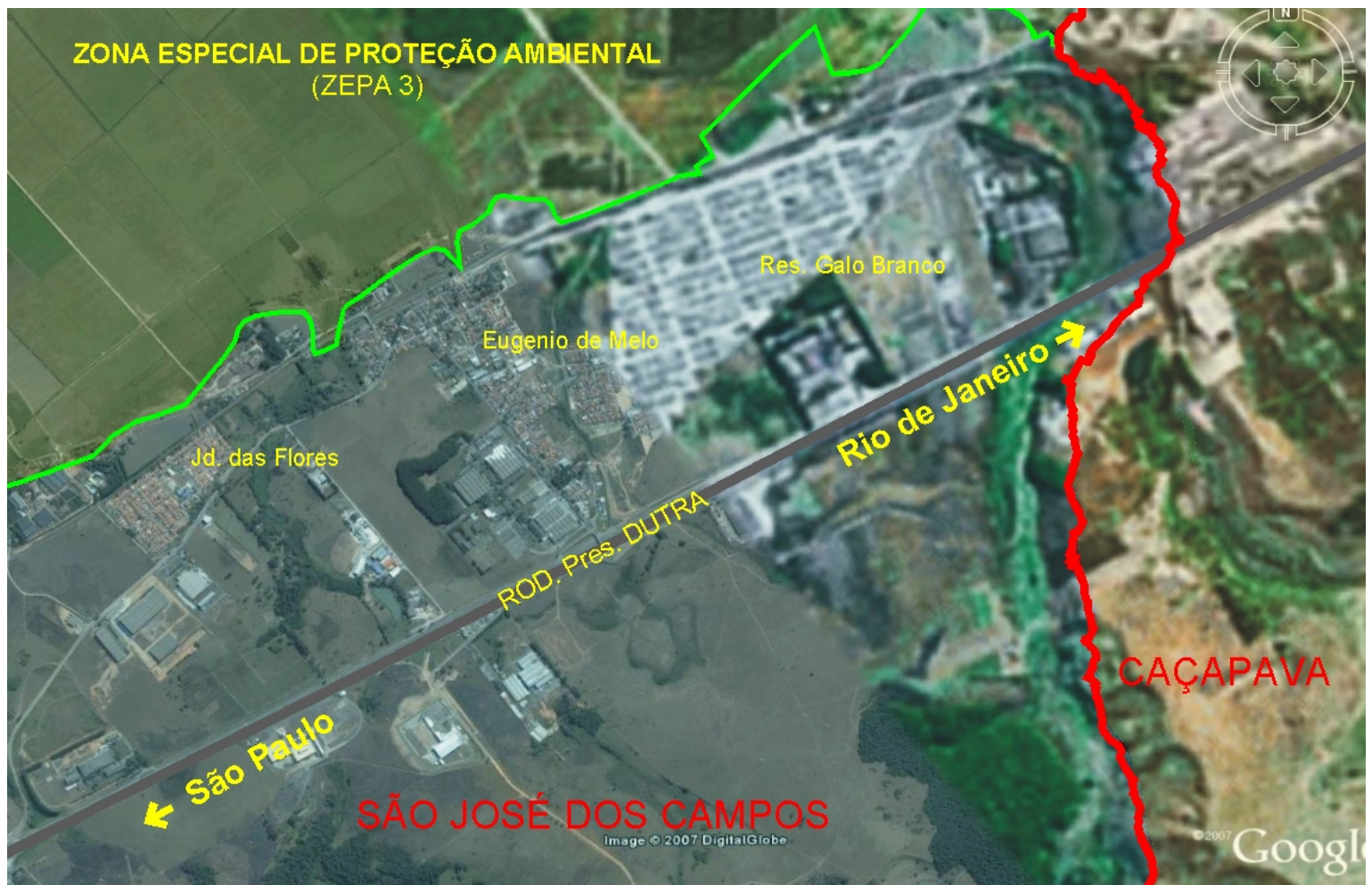

Figura 1.7 - Conurbação com Caçapava - limite Leste Fonte: Google, 2006.

Em relação às áreas internas de São José dos Campos, essas cresceram e foram mais intensas em direção ao Sul, entre as Rodovias Dutra e Carvalho Pinto. Ao Norte, as barreiras físicas representadas pelo Rio Paraíba do Sul, pela ferrovia e pela legislação de proteção ambiental estadual e federal impedem, até certo ponto, o crescimento em toda extensão.

O Plano Diretor de 1995, no sentido de ordenar a ocupação na área urbana de forma contínua, planejada multidisciplinarmente e participativa, adotou a política de ocupação urbana que tomava como base, além dos instrumentos de intervenção urbana e do conceito das Unidades Territoriais, a criação na das Unidades de Planejamento $\mathrm{UP}^{9}$.

\footnotetext{
${ }^{9}$ As Unidades de Planejamento adotadas no PDDI de 1995 são porções da área urbana e de expansão urbana, constituídas por áreas com continuidade geográfica, definidas segundo indicadores de integração e compartimentação. Dentro de seus limites estão contidos os bairros, estes entendidos como "porções do território municipal, que reúnem pessoas que utilizam os mesmos equipamentos urbanos, dentro de limites reconhecidos pela população" (PDDI - 1995).
} 
2) A expansão induzida pela instalação de conjuntos habitacionais e por grandes equipamentos

A desarticulação entre a política urbana e a política habitacional durante as décadas de 70 e 80, ocasionou a localização dos loteamentos de baixa renda em regiões periféricas, contribuindo para a expansão desordenada da mancha urbana, encarecendo o provimento de infra-estrutura e segregando espacialmente a população de baixa renda, principalmente ao Sul do município.

Estes equipamentos e o solo barato atraíram, quase sempre, loteamentos clandestinos ou irregulares e um padrão horizontal com grandes vazios, característica dos assentamentos habitacionais de baixa renda nesta região, o que tem ocasionado o espraiamento descontrolado da mancha urbana e provocado conurbações com os municípios limítrofes.

Na Região Sul a expansão urbana ocorreu de forma mais intensa. Citamos como exemplo a construção do loteamento Campo dos Alemães, fig. 1.8, distante $12 \mathrm{~km}$ da Zona Central que reforçou a expansão nesse vetor.

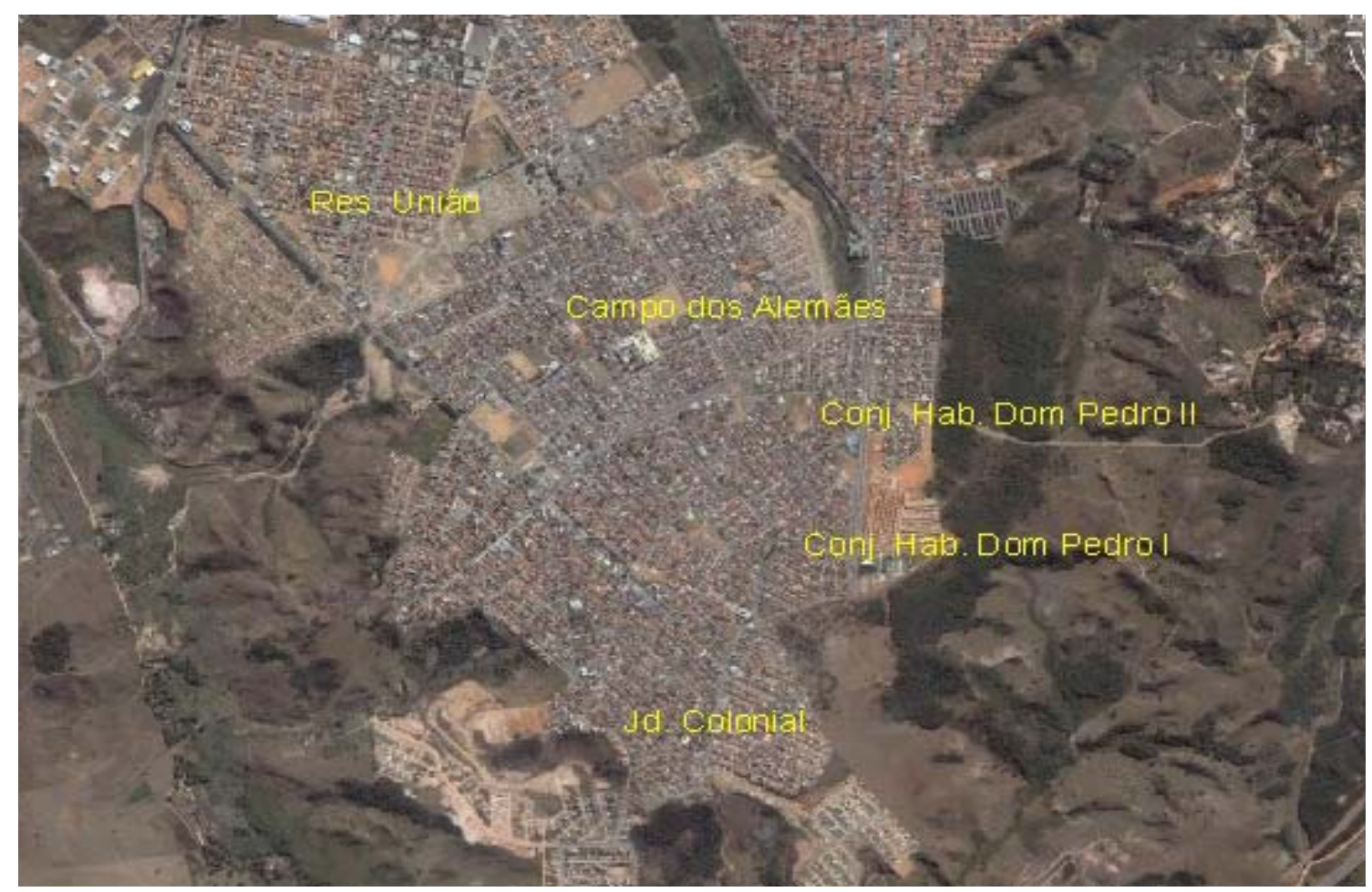

Figura 1.8 - Bairro do Campo dos Alemães e Conjunto Habitacional Dom Pedro I e II Fonte: Google, 2006. 


\subsection{A construção do Pólo Regional de São José dos Campos}

Na década de $1950^{10}$, deu-se o início, em São José dos Campos, ao processo de industrialização e de urbanização mais intensos e a formação do pólo tecnológico com a instalação do Instituto Tecnológico da Aeronáutica - ITA, o primeiro dos institutos do Centro Técnico Aeroespacial - CTA, cujas atividades de ensino e pesquisa sempre estiveram integradas ao setor produtivo.

Com efeito, o processo industrial que, no início da década de 50 ocorreu no município, também trouxe um aumento populacional significativo e a difusão de uma economia urbano-industrial.

Em 1961, foi criado o Instituto Nacional de Pesquisas Espaciais - INPE, outro importante centro irradiador de conhecimento, sendo o principal organismo civil brasileiro voltado para a realização de atividades espaciais. Tratando-se, em ambos os casos, de atividades estratégicas do ponto de vista do governo federal, os financiamentos foram significativos e deram impulso à constituição do pólo tecnológico.

É importante ressaltar que os pólos tecnológicos não se criam por projeto ou decreto. Eles surgem a partir de pré-condições existentes em determinado local e incluem a presença de, pelo menos, uma universidade ou instituto de pesquisas que funciona como âncora desse pólo, como é o caso de São José dos Campos e Campinas.

As intervenções do Estado nesta região foram, aparentemente, maiores que nas outras. O marco do processo de intervenção deu-se no período sanatorial. A migração de doentes para a cidade, numa ação conjunta da filantropia e do Estado, levou a cidade a um caos urbano. O período sanatorial, que começou no final do século XIX e se estendeu até o final da década de 50 , foi responsável pela constatação de que São

\footnotetext{
${ }^{10}$ Nesse período, a ação do Estado se fez presente de maneira marcante, incidindo sobre a urbanização.
} 
José dos Campos precisava de normatização do seu espaço e de condutas em relação à doença e ao doente.

A partir do momento em que a cidade torna-se uma Estância Climática ${ }^{11}$ ela passou a receber investimentos estatais e a fazer parte das estratégias governamentais no que diz respeito à política territorial desenvolvimentista da Ditadura Vargas. Esse processo de investimento na cidade sanatorial criou as bases de infra-estrutura que viabilizaram a cidade industrial moderna.

Ainda no período sanatorial, início da década de 20, começou o processo de industrialização. Em função de incentivos da Prefeitura de São José dos Campos começaram a ser instaladas as primeiras fábricas de cerâmica e têxtil.

Em 1938, foi elaborado o primeiro zoneamento que dividia a cidade em Zonas: Sanatorial, Industrial, Comercial e Residencial.

Na década de 40, foi desencadeado o processo planejador e interventor, por parte do Estado ditatorial de Vargas. Essa política teve como base o Planejamento Regional e o controle estatal. O modelo adotado foi a política do governo Roosevelt: New Deal, principalmente, o TVA - Tennessee Valley Authority, em que a bacia hidrográfica passou a ser referência territorial.

Em 1941 foi encomendado ao IAC - Instituto Agronômico de Campinas, pelo governo estadual, um plano que provesse o desenvolvimento do Vale do Paraíba. Apesar de ter sido um plano que, num primeiro momento, visava um reerguimento pelo incentivo à agropecuária - esse plano já destacava a vocação industrial do eixo Rio-São Paulo.

No final da década de 1950, por meio de um convênio com o Centro de Pesquisas Urbanas da Faculdade de Arquitetura e Urbanismo da USP, foi dada a continuidade do processo de planejamento que teve início no Governo Adhemar de Barros, agora em nível intra-urbano. A construção do CTA em 1948 e a duplicação da Via Dutra em 1951 marcaram o início da transformação da indústria no Vale do Paraíba.

\footnotetext{
${ }^{11}$ Decreto Estadual $n^{0} 7.007 / 35$.
} 
Em 1961, foi elaborado um plano preliminar que constatou que, até aquele momento, não havia um planejamento regional e surgiu a necessidade da criação de um consórcio com as cidades do Vale do Paraíba.

O planejamento e a presença militar, especificamente, em relação ao projeto aeronáutico e de tecnologia de informação, na década de 60 , foi de grande importância para o planejamento urbano de São José dos Campos.

Em 1970, no Plano CODIVAP - Consórcio de Desenvolvimento Integrado do Vale do Paraíba e Litoral Norte e no Plano Regional do Macro-Eixo Paulista foram reafirmadas tendências para a vocação pelo aspecto econômico da região do Vale e, no escopo desses planos, também foram indicadas políticas públicas para o corredor da Via Dutra. Todos esses planos faziam parte de uma estratégia maior do Governo Militar contemplada pelos Planos Nacionais de Desenvolvimento - PND I e II.

Em 1997, a imprensa nacional destacou a cidade de São José dos Campos entre as dez mais, a $9^{a}$ colocada, com características especialmente favoráveis para a realização de negócios ${ }^{12}$ recebendo, neste mesmo ano, o prêmio de cidade empreendedora pelo SEBRAE.

De acordo com a pesquisa ${ }^{13}$ elaborada em conjunto com o IBGE e a Fundação SEADE e divulgada pelo Jornal Folha de São Paulo, em 18 de novembro de 2005, apenas 10 municípios paulistas concentravam 50\% do PIB do Estado de São Paulo. Na pesquisa nacional, dez dos 5.560 municípios do Brasil responderam por 25\% da soma de bens e serviços do país.

\footnotetext{
12 A pesquisa da revista Exame vem utilizando os seguintes critérios (desde de 1997): Foram feitos parte do levantamento em municípios com população entre 50.000 e 450.000 habitantes (num total de 462). A partir daí, foram utilizados três fatores para a classificação, cada um deles com pesos diferenciados. Primeiro, são apurados e computados o volume de investimentos nos últimos três anos. Procura-se também computar o efeito multiplicador de tais recursos para o município. Junto com isso, verifica-se o crescimento populacional entre 1991 e 2000. São levados em conta diversos subitens, como qualidade de vida, o número de leitos hospitalares, o de crianças e jovens matriculados no primeiro e segundo graus e o percentual de residências com energia elétrica e servida de rede de água e esgotos. Também outros dois subitens são contabilizados: o acesso a portos ou rodovias e o número de telefones.

${ }^{13}$ Os dados da pesquisa se referem ao ano de 2003.
} 
Segundo o SEADE, os dez municípios mais ricos de São Paulo são: São Paulo, Guarulhos, São Bernardo do Campo, São José dos Campos, Campinas, Paulínia, Barueri, Santo André, Osasco e Sorocaba e concentraram 16\% do PIB do Brasil em 2003. Esses municípios estão localizados na região metropolitana de São Paulo ou estão no raio de $100 \mathrm{~km}$ da capital e são influenciados pela indústria.

Dos dez mais ricos no Estado, seis estão na Grande São Paulo: São Paulo, Guarulhos, São Bernardo do Campo, Barueri, Santo André e Osasco. Enquanto que São José dos Campos, Campinas e Sorocaba estão no entorno da região metropolitana, somente um pouco mais distante, Paulínia, entra nesse grupo devido aos recentes aumentos do preço do petróleo.

A concentração de renda ainda indica que, apenas 57 dos 645 municípios paulistas agregam $75 \%$ da soma das riquezas e serviços do Estado. Esses municípios estão localizados além da região metropolitana de São Paulo, nas regiões de Campinas, São José dos Campos, Sorocaba e Santos.

Por outro lado, São Paulo foi a capital brasileira que mais perdeu participação no PIB nacional entre 1999 e 2003, segundo estudo divulgado pelo IBGE. Em 1999, São Paulo detinha $11,6 \%$ de participação; em 2003 , esse percentual caiu para $9,4 \%$. A cidade do Rio de Janeiro apareceu em segundo lugar. Curitiba, Salvador e Porto Alegre seguem a lista de capitais com forte redução de participação.

A pesquisa do IBGE analisou o PIB dos 5.560 municípios brasileiros e mostrou que, apesar de ter registrado queda, a capital paulista permaneceu em primeiro lugar na contribuição ao PIB do país. A pesquisa também registra que, entre 1999 e 2003, a participação percentual das capitais no PIB nacional diminuiu, enquanto que municípios fora das regiões metropolitanas cresceram.

As capitais que tinham $32 \%$, em 1999 , reduziram seu percentual para $28 \%$ em 2003. Fora das regiões metropolitanas das capitais, a participação cresceu de $46 \%$ 
para 50\%, influenciada pela exploração e produção de petróleo, pela agropecuária e por incentivos fiscais que provocaram a interiorização de algumas empresas industriais.

Segundo a pesquisa realizada pela SECEX - Secretaria de Comércio Exterior do Ministério do Desenvolvimento, Indústria e Comércio Exterior em março de 2005, a cidade liderou o ranking das cidades que mais exportaram no Estado de São Paulo em 2004.

Conforme levantamento divulgado pelo Ciesp de Campinas, as empresas de São José dos Campos exportaram um total de US\$ 4,7 bilhões em 2004, ocupando o primeiro lugar. Em segundo e terceiro lugar ficaram as cidades de São Paulo, com aproximadamente 3,7 bilhões e São Bernardo com 2,8 bilhões.

Tabela 1.2 - Classificação de São José dos Campos em relação aos municípios do Estado de São Paulo

\begin{tabular}{lc}
\hline \multicolumn{1}{c}{ Localidade } & Exportação em 2004 (US\$) \\
\hline Brasil & 96,5 bilhões \\
Estado de São Paulo & 31 bilhões \\
São José dos Campos $\left(1^{\circ}\right)$ & 4,70 bilhões \\
São Paulo $\left(2^{\circ}\right)$ & 3,68 bilhões \\
São Bernardo do Campo $\left(3^{\circ}\right)$ & 2,76 bilhões \\
Taubaté $\left(13^{\circ}\right)$ & 427 milhões \\
Pindamonhangaba $\left(15^{\circ}\right)$ & 373 milhões \\
São Sebastião & 299 milhões \\
\hline
\end{tabular}

Fonte: SECEX - Secretaria de Comércio Exterior do Ministério do Desenvolvimento, Indústria e Comércio Exterior, 2005.

A Embraer, principal exportadora do município, comercializou US\$ 3,3 bilhões no ano de 2004. Neste ano, São José dos Campos passou a ser a primeira cidade, em exportação, do estado mais rico do Brasil, com grande concentração de renda.

Em 2005, São José dos Campos passou a ocupar a segunda posição no ranking das cidades que mais exportam no país, com volume de US\$4,9 bilhões e o município passou do terceiro para o segundo lugar entre exportações e importações, com 
um superávit de US\$2,3 bilhões. Segundo estatísticas, São José dos Campos é apenas superada pela capital São Paulo, que exportou US\$ 5,604 bilhões ${ }^{14}$.

No entanto, ao observarmos, tabelas 1.3, 1.4 e 1.5, alguns indicadores do município que se referem a índices de esperança de vida (IDHM-L), taxas de alfabetização, de freqüência escolar e renda per capita mostram que a cidade possui um desempenho não correspondente ao seu atual desenvolvimento econômico.

Tabela 1.3 - São José dos Campos e os principais índices de qualidade de vida

\begin{tabular}{lccccc}
\hline \multicolumn{2}{c}{ São José dos Campos } & IDH-M 2000: $\mathbf{0 , 8 4 9}$ & \multicolumn{2}{c}{ Ranking: $\mathbf{1 1}$} \\
\hline $\begin{array}{l}\text { Índice de } \\
\begin{array}{l}\text { esperança de } \\
\text { vida (IDHM-L) }\end{array}\end{array}$ & Ranking & $\begin{array}{c}\text { Índice de Educação } \\
\text { (IDHM-E) }\end{array}$ & Ranking & $\begin{array}{c}\text { Índice PIB } \\
\text { (IDHM-R) }\end{array}$ & Ranking \\
0,815 & 114 & 0,933 & 6 & 0,8 & 21 \\
\hline
\end{tabular}

Fonte: Secretaria de Planejamento Urbano de São José dos Campos, PMSJC, 2005.

Tabela 1.4 - A evolução do IDH-M e seus componentes - São José dos Campos

\begin{tabular}{ccc}
\hline Ano & $\mathbf{1 9 9 1}$ & $\mathbf{2 0 0 0}$ \\
\hline IDH-M & 0,805 & 0,849 \\
IDH-M Longevidade & 0,776 & 0,815 \\
IDH-M Educação & 0,877 & 0,933 \\
IDH-M Renda & 0,763 & 0,800 \\
\hline
\end{tabular}

Fonte: Secretaria de Planejamento Urbano, PMSJC, 2005.

Tabela 1.5 - Índices de esperança de vida, alfabetização, freqüência escolar e renda per capita

\begin{tabular}{cccc}
\hline $\begin{array}{c}\text { Esperança de vida Taxa de Alfabetização } \\
\text { ao nascer }\end{array}$ & $\begin{array}{c}\text { Taxa Bruta de } \\
\text { fe Adultos }\end{array}$ & $\begin{array}{c}\text { Renda per } \\
\text { Capiência Escolar }\end{array}$ \\
\hline 73,9 & 0,95 & 0,89 & 470,02 \\
\hline
\end{tabular}

Fonte: Secretaria de Planejamento Urbano, PMSJC, 2005.

${ }^{14}$ Dados divulgados pela SECEX - Secretaria de Comércio Exterior, órgão vinculado ao Ministério do Desenvolvimento, Indústria e Comércio. 
São José dos Campos é, atualmente, apontada como cidade emergente. O aumento de indústrias foi causado, entre outros, pela imagem de cidade dinâmica e competitiva que passou a representar no espaço nacional.

O fato é que, mesmo considerando que São José dos Campos apresenta condições que a tornam importante receptora de investimentos, não se pode deixar de considerar que todo esse crescimento econômico não conseguiu trazer correspondente retorno para a qualidade de vida urbana local, para a população de baixa renda ${ }^{15}$.

Muitas cidades médias do interior paulista estão seguindo a trilha daquelas que, por uma série de circunstâncias, estiveram à frente das políticas de atração industrial e repetem, 30 anos depois, o que aconteceu na década de 70: a disputa pela atração de investimentos recentemente promovida, principalmente, pelos estados.

São José dos Campos é uma das cidades que participa desta fase de crescimento econômico, mas como iremos observar no Capítulo 2 sobre a Evolução Urbana e, no Capítulo 3, sobre a Legislação Urbanística, este fato torna-se ainda mais preocupante. Há ausência de uma política urbana claramente definida, o que realça a desigual distribuição da infra-estrutura e a emergência de bolsões de ocupação ilegal nas regiões periféricas da cidade.

Como em qualquer outra cidade brasileira, o cotidiano da população joseense é marcado pela diferença da qualidade de vida em relação aos habitantes das áreas mais nobres. Independente da conotação que o termo desenvolvimento possa ter, para efeito desta tese, ele será utilizado para designar um processo capaz de proporcionar melhores condições de vida às pessoas, não se limitando às questões de caráter econômico, mas abrangendo também as sociais, as culturais e as territoriais.

Foram identificados, durante nossa pesquisa, os seguintes aspectos que interferem na condição de vida da população decorrentes da ineficiência dos seguintes

\footnotetext{
${ }^{15}$ Qualidade de vida como um conceito que expressa a condição de bem-estar dos habitantes de uma cidade.
} 
problemas: política urbana e habitacional; compatibilização entre projetos setoriais e planejamento urbano local; instrumentos fundiários e gestão integrada intermunicipal. 


\section{CAPÍTULO 2 - CARACTERIZAÇÃO DO MUNICÍPIO DE SÃO JOSÉ DOS CAMPOS}

O município de São José dos Campos está situado a Leste do Estado de São Paulo ao longo do eixo Rio - São Paulo, na região do Vale do Paraíba, destacando-se entre os mais importantes dos 35 municípios que compõem a Bacia do Rio Paraíba do Sul. (Fig. 2.1)

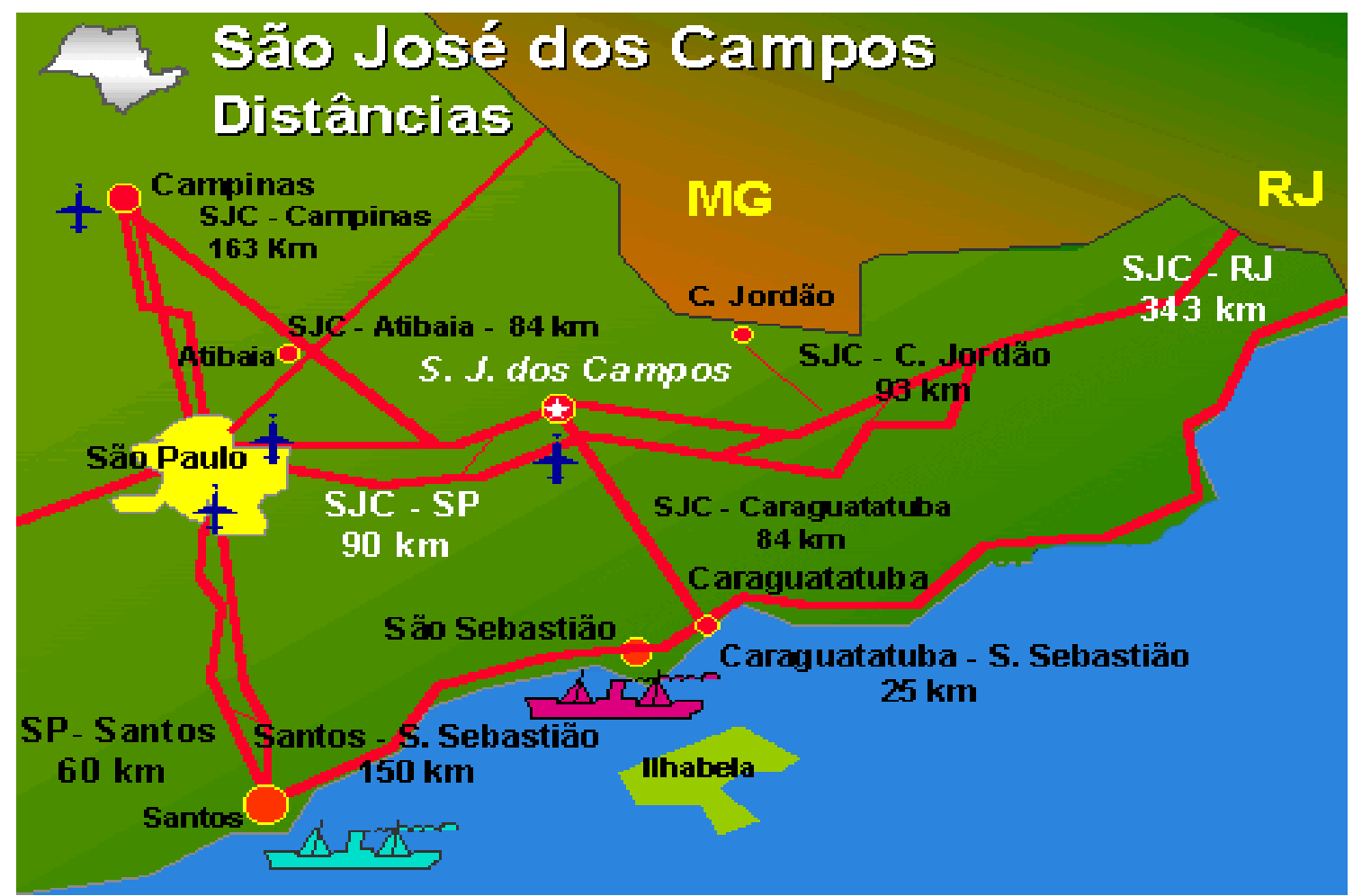

Figura 2.1 - Mapa de distâncias

Fonte: Secretaria de Planejamento e Meio Ambiente - SPMA, PMSJC, 2005.

O município é constituído oficialmente por três distritos: São José dos Campos (sede), Eugênio de Melo e São Francisco Xavier, sendo que o distrito de São José dos Campos é dividido em dois subdistritos: $1^{\circ}$ Subdistrito de São José dos Campos e $2^{\circ}$ Subdistrito de Santana do Paraíba. (Fig. 2.2) 


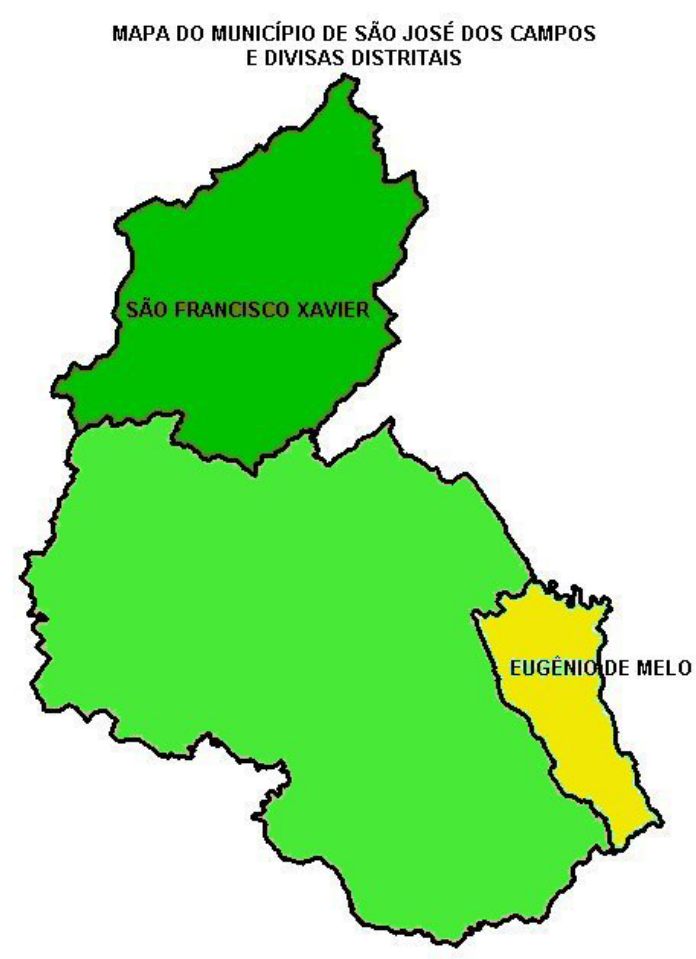

Figura 2.2 - Mapa dos distritos de São José dos Campos

Fonte: Secretaria de Planejamento e Meio Ambiente - SPMA, PMSJC, 2005.

O território de São José dos Campos abrange uma área de 1.099,6km² 70\% desta área está localizada ao Norte da Rodovia Presidente Dutra - constituída por montanhas, serras e picos com exceção do platô da Região Central. A porção Sul, que corresponde a $30 \%$ do território, apresenta um relevo mais brando e suave formado por um planalto composto de uma série de platôs entrecortados por pequenos vales.

A existência de acidentes naturais e artificiais influi de forma decisiva nas possibilidades da expansão da cidade. Ao Norte, o rio Paraíba do Sul e sua várzea plana e turfosa; assim como os trechos de topografia montanhosa, limitam a expansão do sítio urbano atual.

Os afluentes da margem direita do rio Paraíba do Sul - o córrego Serimbura, o ribeirão Vidoca, o ribeirão dos Putins, o rio Alambari e o ribeirão Pararangaba também oferecem algumas limitações para a ocupação urbana. O Centro Técnico Aeroespacial - CTA, ao sul da Rodovia Presidente Dutra, ocupa uma área de 1200 hectares e constitui uma barreira para a expansão do sítio urbano, assim como a área 
ocupada pela Refinaria Henrique Laje - REVAP, na Região Leste, que acabou por deslocar para o extremo Leste o vetor de crescimento da cidade.

Mas é sua posição estratégica em relação às duas maiores regiões metropolitanas do país e a proximidade do porto de São Sebastião, que apresenta grandes potencialidades para a movimentação de cargas especializadas.

Também a implantação do Centro Técnico Aeroespacial - CTA e do Instituto Nacional de Pesquisas Espaciais - INPE contribuíram para a existência de um moderno parque industrial no município, refletindo no crescimento das atividades de comércio e de prestação de serviços, o que confere a São José dos Campos, condição de destaque em relação aos demais núcleos urbanos da região. O município é sede da $3^{a}$ região administrativa do Estado de São Paulo que abrange os 35 municípios do Vale do Paraíba e quatro do Litoral Norte.

Com uma população de 615.618 habitantes, segundo estimativas do IBGE para o ano de 2006, e valor adicionado per capita de $\mathrm{R} \$ 27,5$ mil reais em 2004, São José dos Campos é um dos centros industriais e de serviços mais importantes do interior paulista, sendo a $5^{a}$ cidade no índice de participação dos municípios e $3^{a}$ do Estado de São Paulo em valor adicionado de ICMS, o que representa cerca de $47 \%$ de todo o Vale do Paraíba.

Quanto à distribuição populacional, os dados censitários de 2000 indicam, para São José dos Campos, uma taxa de urbanização de 98,78\%. A evolução da evolução populacional do município pode ser observada na Tabela 2.1. Entre as décadas de 80,90 e 2000, as variações ocorridas na composição da população urbana e rural relacionam-se com sucessivas modificações na legislação municipal referente à delimitação dos perímetros urbano e rural (expansão / retração). 
Tabela 2.1 - Evolução populacional do Município 1940-2000

\begin{tabular}{cccc}
\hline ANO & \multicolumn{3}{c}{ POPULAÇÃO } \\
\hline & TOTAL & URBANO & RURAL \\
$\mathbf{1 9 4 0}$ & 36.279 & 14.474 & 21.805 \\
$\mathbf{1 9 5 0}$ & 44.804 & 26.600 & 18.204 \\
$\mathbf{1 9 6 0}$ & 77.533 & 56.882 & 20.651 \\
$\mathbf{1 9 7 0}$ & 148.332 & 132.482 & 15.850 \\
$\mathbf{1 9 8 0}$ & 287.513 & 276.901 & 10.612 \\
$\mathbf{1 9 9 1}$ & 442.370 & 425.515 & 16.855 \\
$\mathbf{2 0 0 0}$ & 539.313 & 532.717 & 6.596 \\
\hline
\end{tabular}

Fonte: IBGE - Censo Demográfico, 2000.

É importante destacar que o crescimento populacional ocorreu com intensidade diferente nas seis regiões geográficas que compõem São José dos Campos.

Segundo o Censo Demográfico de 2000, a Região Sul concentra o maior volume populacional, o que corresponde a $37,55 \%$ da população total. Em seguida, posicionam-se a Região Leste com 25,58\%; a Região Centro com 13,31\% e a Região Norte com $11,55 \%$. Menos populosas são as regiões Sudeste com 7,28\% da população total e a Oeste, com $4,73 \%$ do total (Tabela 2.2).

Tabela 2.2 - População Segundo Regiões Urbanas Município de São José dos Campos 2000

\begin{tabular}{cccccc}
\hline Região & $\begin{array}{c}\text { População } \\
\text { total 2000 }\end{array}$ & $\begin{array}{c}\text { Distribuição } \\
\text { relativa(\%) }\end{array}$ & $\begin{array}{c}\text { Domicílios } \\
\text { ocupados }\end{array}$ & $\begin{array}{c}\text { Distribuição } \\
\text { relativa (\%) }\end{array}$ & $\begin{array}{c}\mathbf{N}^{\mathbf{0}} \text { de pessoas } \\
\text { por domicilio }\end{array}$ \\
\hline Centro & 70.863 & 13,31 & 21.586 & 15,07 & 3,28 \\
Norte & 61.504 & 11,55 & 16.436 & 11,48 & 3,74 \\
Leste & 136.180 & 25,58 & 35.753 & 24,95 & 3,81 \\
Sudeste & 38.761 & 7,28 & 9.598 & 6,7 & 4,04 \\
Sul & 199.913 & 37,55 & 52.698 & 37,8 & 3,79 \\
Oeste & 25.182 & 4,73 & 7.147 & 4,99 & 3,52 \\
Total & 532.403 & 100 & 143.218 & 100,99 & 3,72 \\
\hline
\end{tabular}

Fonte: Secretaria de Planejamento Urbano, PMSJC, com base no Censo Demográfico de 2000 - IBGE. 
A Figura 2.3 e a Tabela 2.3 mostram a distribuição populacional no espaço urbano de São José dos Campos e o crescimento populacional segundo regiões urbanas.

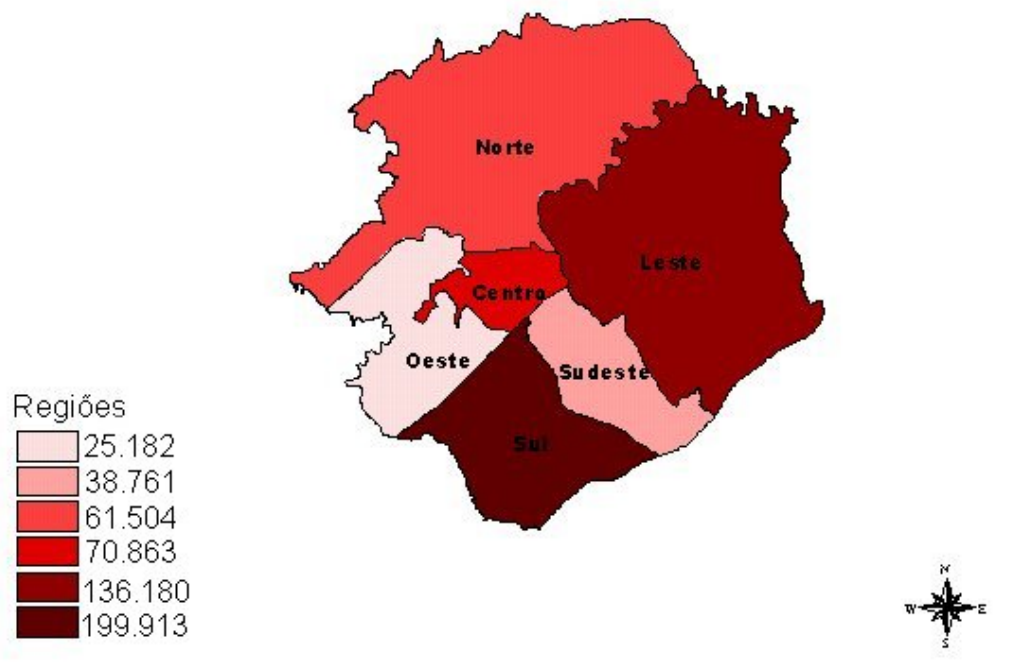

Figura 2.3 - Distribuição da População Segundo Regiões Urbanas

Fontes: IBGE - Censo Demográfico 2000 e Secretaria de Planejamento Urbano, PMSJC.

Tabela 2.3 - Taxa de Crescimento da População Segundo Regiões Urbanas Município de São José dos Campos - 1991-2000

\begin{tabular}{cccc}
\hline Região & População 1991 & $\begin{array}{c}\text { População } \\
\mathbf{2 0 0 0}\end{array}$ & $\begin{array}{c}\text { Taxa de crescimento ao } \\
\text { ano (\%) 1991-2000 }\end{array}$ \\
\hline Centro & 75.356 & 70.863 & $-0,68$ \\
Norte & 54.340 & 61.504 & 1,39 \\
Leste & 100.484 & 136.180 & 3,44 \\
Sudeste & 30.479 & 38.761 & 2,71 \\
Sul & 156.736 & 199.913 & 2,74 \\
Oeste & 14.205 & 25.182 & 6,57 \\
\hline
\end{tabular}

Fontes: IBGE - Censos Demográficos e Secretaria Planejamento Urbano, PMSJC.

$\mathrm{Na}$ Tabela 2.4 são apresentadas as estimativas populacionais divulgadas anualmente pelo IBGE para o município, após o Censo de 2000, e uma projeção do crescimento populacional de São José dos Campos calculado a partir da taxa geométrica de crescimento anual de 2,23\%, ocorrida no último período intercensitário. 
Tabela 2.4 - Estimativas populacionais e projeção da população Município de São José dos Campos

\begin{tabular}{lcc}
\hline ANO & \multicolumn{1}{c}{ POPULAÇÃo } \\
\hline & Estimativa oficial IBGE & Projeção * \\
2001 & 550.762 & \\
2002 & 559.710 & \\
2003 & 569.177 & \\
2004 & 589.050 & \\
2005 & 600.049 & \\
2006 & & 615.618 \\
2007 & & 629.346 \\
2008 & & 643.380 \\
2009 & & 657.728 \\
2010 & & 672.395 \\
2011 & & 687.389 \\
2012 & & 702.718 \\
2013 & & 718.389 \\
2014 & & 734.409 \\
2015 & & 750.786 \\
\hline
\end{tabular}

*Projeção populacional: simulação feita com base na taxa de 2,23\% ao ano, verificada no último período intercensitário.

Fontes: IBGE e Secretaria de Planejamento Urbano, PMSJC.

\subsection{A Região Administrativa de São José dos Campos}

A Região Administrativa de São José dos Campos $^{16}$ abrange 55 núcleos urbanos, em que se incluem 39 sedes de municípios (35 no Vale do Paraíba e 4 no Litoral Norte) e 16 sedes de distritos.

${ }^{16}$ Decreto Estadual $n^{0} 26.581$ de 05/01/87. 


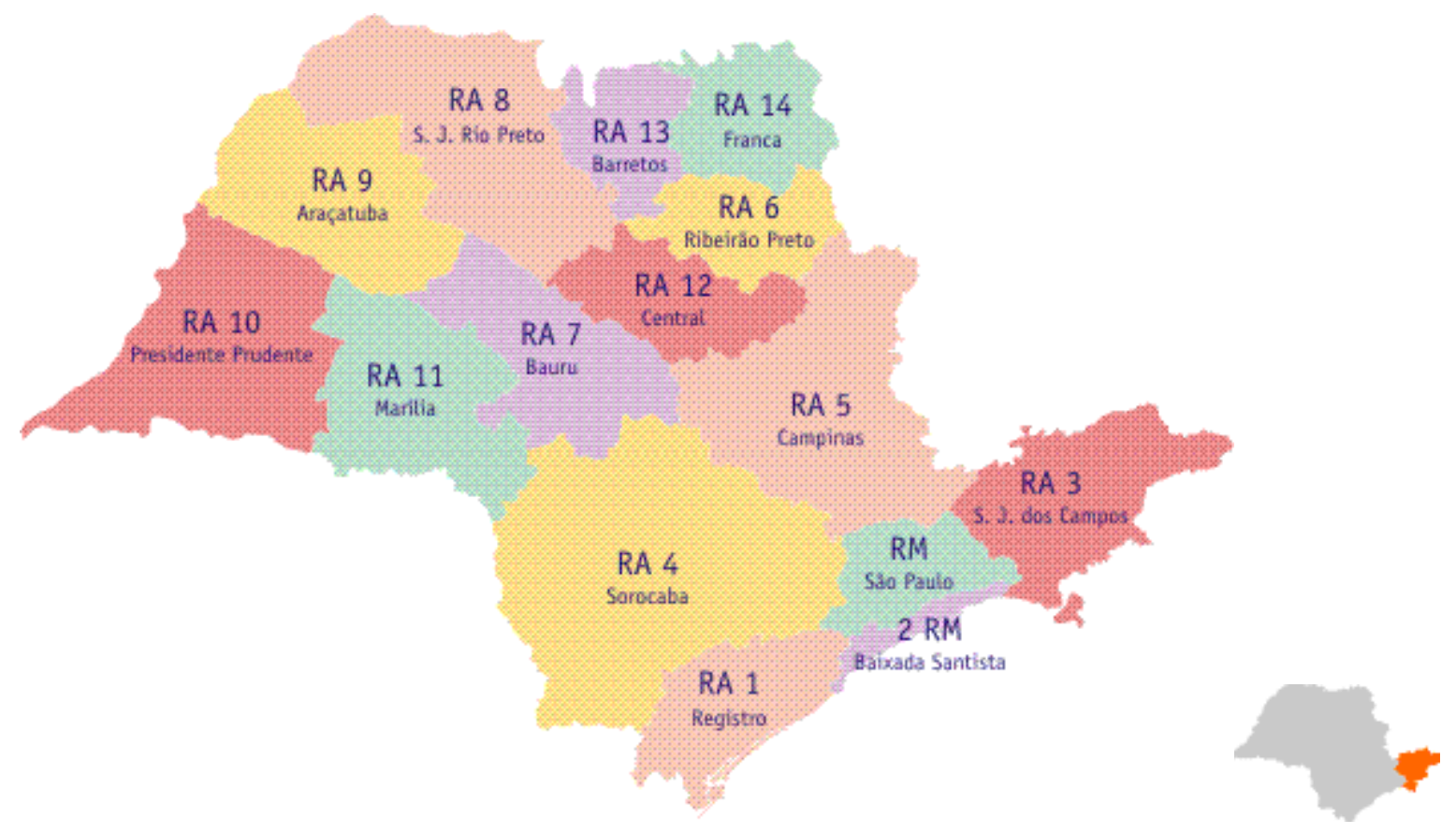

Figura 2.4 - Mapa das Regiões Administrativas do Estado de São Paulo Fonte: ERPLAN, Estado de São Paulo, 2005.

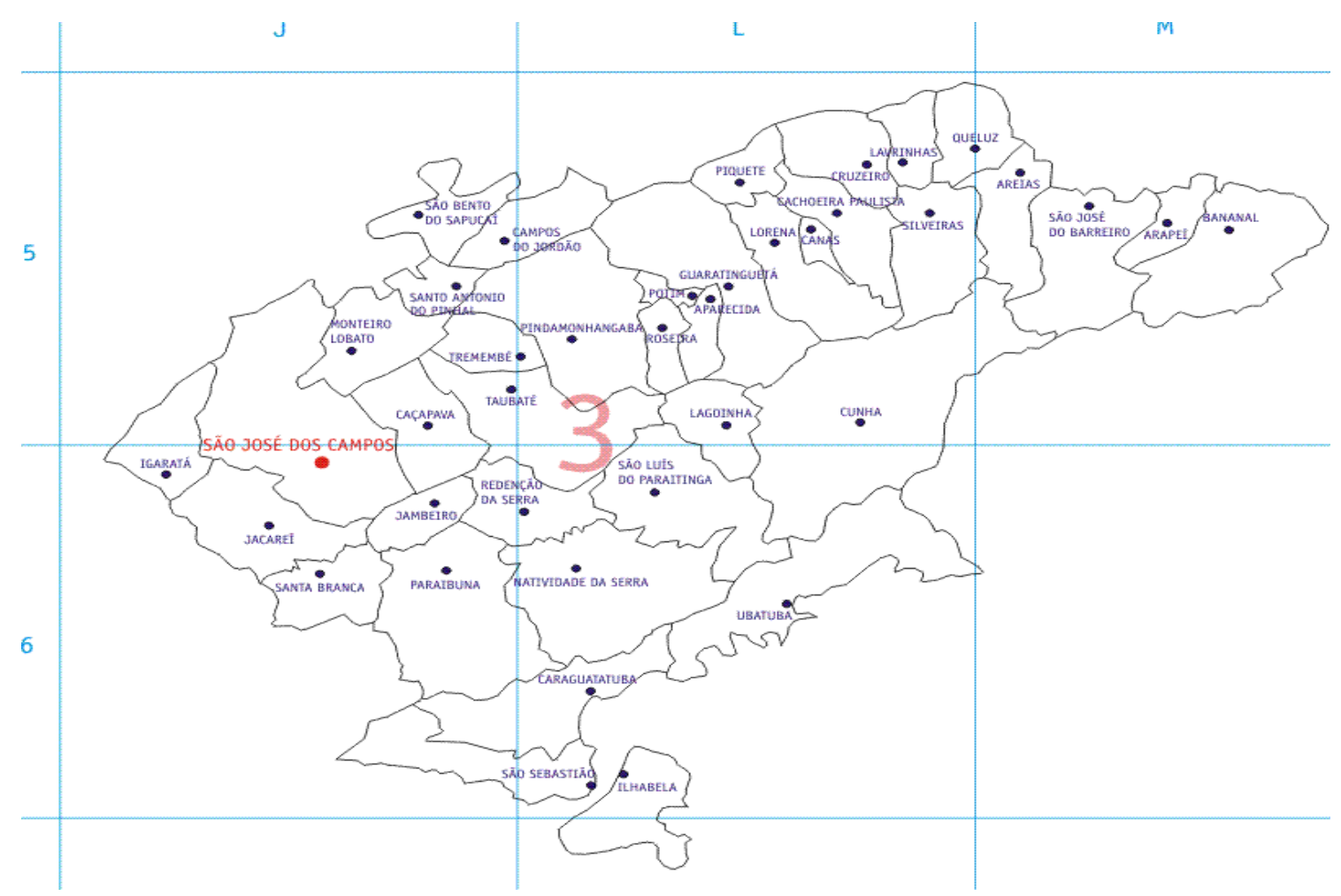

Figura 2.5 - $3^{\text {a }}$ Região Administrativa de São José dos Campos Fonte: ERPLAN - Estado de São Paulo, 2006. 
A distribuição espacial dos municípios pode ser vista sob dois aspectos: pelo eixo rodoviário da Presidente Dutra e pela bacia hidrográfica do Rio Paraíba do Sul.

Em 1970, Jacareí, Caçapava e Taubaté possuíam 385 estabelecimentos industriais que empregavam 14,2 mil pessoas. Em São José dos Campos, na mesma data, havia 275 estabelecimentos, com 17,8 mil pessoas ocupadas. ${ }^{17}$

Retomando dados apresentados no Capítulo 1, nessa década, diferentemente, a indústria de São José dos Campos já tinha outra dimensão. Com o surgimento de grandes empresas do município, os antigos estabelecimentos perderam peso, principalmente para os ramos metalúrgico, de material, de transporte, material elétrico e vestuário. Em proporção muito inferior, este processo também teve curso em Taubaté.

Assim sendo, antes mesmo que a interiorização da indústria ganhasse uma dimensão maior, na década de 70, estes municípios do Alto Vale do Paraíba já sediavam alguns dos mais importantes estabelecimentos industriais do interior do Estado, de acordo com Negri (1988).

Segundo Oliveira \& Tartaglia (1988, p.47) na agricultura, contudo, o Vale do Paraíba apresentava um desempenho econômico bastante acanhado. "Nenhum produto apresentou contribuição significativa para a produção do Estado".

De todas as atividades locais, a mais importante continuou sendo a pecuária leiteira praticada, quase que exclusivamente, com pastagens naturais e padrões baixos de produtividade. Seu resultado mais expressivo foi o incentivo à indústria regional de laticínios. A área cultivada regrediu, após 1930, quando ocupava 18\% para situar-se em torno de 5\%, ao final desta década. Em 1970, as pastagens naturais chegaram a ocupar 68\% das terras da Região Administrativa do Vale do Paraíba.

O intenso crescimento industrial destas décadas e o esvaziamento do campo, patrocinado pela pecuária, acabaram por refletir nas populações das principais cidades,

${ }^{17}$ FIBGE. Censo Industrial de 1970. 
concentrando seu crescimento nos maiores municípios, sobretudo em São José dos Campos.

Tabela 2.5 - População de São José dos Campos relativa a região administrativa do Vale do Paraíba e Estado de São Paulo

\begin{tabular}{cccc}
\hline & População Absoluta & \multicolumn{2}{c}{ Estado de São Paulo } \\
\hline \multirow{2}{*}{ Ano } & São José dos Campos & $\begin{array}{c}\text { Região Administrativa } \\
\text { Vale do Paraíba }\end{array}$ & Estado de São Paulo \\
& & 23,54 & 1,15 \\
1980 & 287.513 & 26,78 & 1,40 \\
1991 & 442.370 & 27,07 & 1,46 \\
2000 & 539.313 &
\end{tabular}

Fonte: Secretaria de Planejamento Urbano, PMSJC, 2006.

A tabela 2.6 traz informações acerca dos componentes do crescimento demográfico regional entre 1950 e 1970. Para o conjunto da Região Administrativa, a década de 1960 representa uma ruptura na tendência de esvaziamento anterior. De um saldo migratório negativo, passa-se a fluxos positivos e crescentes de migrantes, embora ainda baixos para o volume da população regional.

Tabela 2.6 - Evolução da população total segundo seus componentes - Região Administrativa do Vale do Paraíba - 1940/1970

\begin{tabular}{cccccc}
\hline Ano & $\begin{array}{r}\text { População } \\
\text { Total \% a. a. }\end{array}$ & $\begin{array}{c}\text { Crescimento } \\
\text { Absoluto }\end{array}$ & $\begin{array}{c}\text { Saldo } \\
\text { Vegetativo }\end{array}$ & $\begin{array}{c}\text { Saldo } \\
\text { Migratório }\end{array}$ & $\begin{array}{c}\text { Taxa de } \\
\text { Crescimento }\end{array}$ \\
\hline 1940 & 376.046 & - & - & - & - \\
1950 & 456.225 & 80.179 & 64.319 & -4.036 & 2,0 \\
1960 & 578.220 & 121.995 & 126.031 & 34.361 & 2,4 \\
1970 & 786.653 & 208.433 & 173.872 & 132.388 & 3,1 \\
\hline
\end{tabular}

Fonte: SEADE, Análise Demográfica Regional: Vale do Paraíba, São Paulo, 1985.

Dadas as características que a região do Vale do Paraíba assumiu, este resultado reflete as tendências demográficas dos municípios do Vale do Paraíba. É basicamente a sub-região de São José dos Campos que determina este crescimento da migração. 
Tabela 2.7 - População das sedes municipais - São José dos Campos, Taubaté, Caçapava e Jacareí

\begin{tabular}{ccccc}
\hline Ano & São José dos Campos & Taubaté & Jacareí & Caçapava \\
\hline 1940 & 13.491 & 27.548 & 11.797 & 7.548 \\
1950 & 25.892 & 35.149 & 15.251 & 10.683 \\
1960 & 55.349 & 64.863 & 28.131 & 7.987 \\
1970 & 129.980 & 98.834 & 48.546 & 24.627 \\
\hline
\end{tabular}

Fonte: SEADE, Análise Demográfica Regional: Vale do Paraíba, São Paulo, 1985.

A tabela 2.7 mostra a população das sedes municipais dos quatro municípios em questão que passa, entre 1940 e 1970, de 60,4 mil para 302,0 mil habitantes. De apenas $16 \%$ da população regional, estes municípios evoluem 38\%, sendo que é em São José dos Campos que o crescimento populacional é mais acentuado: com população urbana similar às de Jacareí, Cruzeiro e Lorena e menor que Taubaté e Guaratinguetá, em 1940, São José torna-se o principal centro regional, ao fim da década de 60.

Em 1970, portanto, já se encontram as bases do crescimento urbano que transformaria estes municípios num dos aglomerados mais importantes do país e que daria à indústria regional um porte mais significativo.

Nessa década, também foi implantada a Refinaria Henrique Lage que veio a se constituir em fator de atração de outros segmentos do ramo químico - Rhodia e Monsanto em São José dos Campos e a Henkel em Jacareí.

Os elevados saldos migratórios que a Região Administrativa do Vale do Paraíba tinha apresentado entre 1970 e 1980, quando o fluxo líquido de migrantes chegou a 132 mil pessoas, mantiveram-se elevados ainda nos anos 80, mas declinaram muito rapidamente entre 1991 e 1996. Nesses últimos cinco anos, a taxa média de crescimento do conjunto da Região Administrativa situa-se muito próximo à taxa média de crescimento vegetativo do Estado de São Paulo, indicando uma migração líquida 
muito baixa. Em 2006, a população estimada desses municípios é de 1.361 .677 habitantes.

Para os principais municípios que formam o Aglomerado do Alto Vale do Paraíba este quadro é similar, ainda que o declínio do crescimento seja menor: a Região de Governo de São José dos Campos seguiu crescendo à taxa média de 1,6\% entre 1991 e 1996. É curioso observar que este padrão de crescimento é relativamente diferenciado de outros aglomerados ou metrópoles em formação no interior do estado. (Tabela 2.8)

No Vale, o município sede do Aglomerado segue apresentando taxas mais elevadas que os demais municípios. As menores taxas são encontradas para Caçapava e Jacareí, enquanto a população de São José dos Campos cresceu em média à taxa de 1,9\% entre 1991 e 1996.

Tabela 2.8 - População dos principais municípios - São José dos Campos, Taubaté, Caçapava e Jacareí - 1970/1996

\begin{tabular}{lcccc}
\hline Ano & São José dos Campos & Taubaté & Jacareí & Caçapava \\
\hline 1970 & 148.332 & 110.585 & 61.216 & 30.712 \\
1980 & 287.513 & 169.265 & 115.732 & 51.347 \\
1991 & 442.370 & 206.965 & 163.869 & 66.058 \\
1996 & 486.467 & 220.230 & 167.751 & 68.117 \\
\hline
\end{tabular}

Fonte: SEADE, Análise Demográfica Regional: Vale do Paraíba, São Paulo, 1985.

A tabela 2.9 reflete uma migração líquida maior, como comprovam os resultados da Contagem Populacional de 1996, acerca dos percentuais mais elevados de migrantes com menos de 5 anos de residência no município. 
Tabela 2.9 - Taxa média de crescimento, taxa de urbanização e índices migratórios

\begin{tabular}{cccccc}
\hline Ano & $\begin{array}{c}\text { São José } \\
\text { dos Campos }\end{array}$ & Taubaté & Jacareí & Caçapava & TOTAL \\
\hline $\mathbf{1 9 7 0 / 8 0}$ & $-6,84$ & 4,35 & 6,58 & 5,27 & 5,92 \\
$\mathbf{1 9 8 0 / 9 1}$ & 3,99 & 1,84 & 3,21 & 2,32 & 3,17 \\
$\mathbf{1 9 9 1 / 9 6}$ & 1,92 & 1,25 & 0,47 & 0,62 & 1,40 \\
$\mathbf{1 9 8 0}(\%)$ & 96,3 & 95,4 & 93,2 & 88,0 & 94,8 \\
$\mathbf{1 9 9 6}(\%)$ & 95,1 & 95,5 & 94,3 & 88,7 & 94,6 \\
$\mathbf{1 9 9 6}(\%)$ & $7,17 \%$ & $6,33 \%$ & $5,41 \%$ & $5,16 \%$ & $6,52 \%$ \\
\hline
\end{tabular}

Fonte: SEADE, Análise Demográfica Regional: Vale do Paraíba, São Paulo, 1985.

Outro indicador que aponta a diferença entre a dinâmica demográfica de São José dos Campos e a do restante da região é a evolução da participação do município no total da população do Vale do Paraíba: 9,8\% em 1950; 13,3\% em 1960; 18,9\% em 1970; 25,4\% em 1980, ultrapassando 30\% em 1996.

Ressaltamos que, atualmente, o Vale do Paraíba é destaque no cenário mundial, como importante centro de desenvolvimento de tecnologia militar e aeroespacial, possuindo grandes empresas aeronáuticas como a EMBRAER e Instituto de Pesquisas Espaciais - INPE e o Centro Tecnológico Aeroespacial - CTA.

\subsection{A Evolução Urbana de São José dos Campos}

Numa primeira abordagem, podemos dizer que São José dos Campos utilizou a legislação urbanística desde a década de 20 até o início de 80 , para que a cidade pudesse se preparar para receber o capital industrial e tornar-se um dos mais importantes pólos regionais do país na década de 90 . 
Verificamos também que o Estado fez inúmeras intervenções com planos e políticas públicas regionais que, aliados aos investimentos industriais e imobiliários privados, fez com que a cidade passasse a atrair novos investimentos.

\subsubsection{Primeiro período: das origens até 1930}

Segundo Rocha Filho ${ }^{18}$, embora não se tenha determinado com segurança a época exata dos primeiros estabelecimentos estáveis do colonizador português em terras onde hoje se situa São José dos Campos, é certo que sua história se inicia quase contemporaneamente à da Capitania de São Vicente, no final do século quinhentista. São José dos Campos foi, primitivamente, uma aldeia de índios guaianazes, emigrados de Piratininga, no ano de 1590.

Em 1611, foi criada a lei ${ }^{19}$ que regulamentava os aldeamentos indígenas nos pontos que melhor conviessem aos interesses do Reino. Entre os antigos aldeamentos que vieram merecer a atenção dos jesuítas figurava, a Leste, o de São José dos Campos, localizado no Bairro do Rio Comprido, a dez quilômetros da cidade atual.

Nessa época, o aspecto da aldeia era a imagem de um pequeno aglomerado, dotado de uma linearidade que lembra os povoamentos dos primeiros períodos póscolônia, ou seja, concentração espacial, atualmente chamada de platô central da cidade. Sua organização urbana, no plano teórico e prático, foi atribuída ao padre jesuíta Manoel de Leão.

Chamada, em 1692, de "Residência do Paraíba do Sul" e, a partir de 1696, de "Residência São José", a aldeia só ganhou status de vila - Vila de São José do Paraíba em 27 de julho de 1767, o que nada determinou para o seu progresso; por muitos anos

\footnotetext{
${ }^{18}$ In: Plano Diretor de Desenvolvimento Integrado de São José dos Campos. Prefeitura Municipal de São José dos Campos, 1994, p. 21.

${ }^{19}$ A Lei de 10 de setembro de 1611 que regulamentava a instalação de aldeamentos de índios dispersos, administrados por religiosos, transformou oficialmente a fazenda em missão de catequese. Esse fato causou desagrado aos colonos que muito necessitavam da mão-de-obra indígena e tiveram suas ações dificultadas. $\mathrm{O}$ resultado desse conflito entre religiosos e colonos culminou com a expulsão dos jesuítas em 1640 e a conseqüente extinção da missão pela própria dispersão dos aldeados.
} 
quase nenhum progresso foi notado. A principal dificuldade apontada era o fato de a Estrada Real ${ }^{20}$ passar fora de seus domínios.

A Vila só ganharia destaque a partir de 1867, por ser a maior produtora de algodão - destinado ao abastecimento das tecelagens inglesas - da região ocidental do Vale.

Segundo Rocha Filho (1994), três outros acontecimentos também marcaram esse período: em 1871, pela lei provincial $n^{\circ} 47$, a povoação passou a se chamar São José dos Campos. Em 1872, foi criada a comarca de São José, que já contava com uma população de 12.988 habitantes, incluindo 1.245 escravos. Por fim, grande alento foi dado ao progresso da cidade, com a chegada, em 1876, da Estrada de Ferro Central do Brasil, cortando o centro urbano e ligando o município ao Rio de Janeiro e a São Paulo.

Concomitantemente, o plantio de café já começava a ser introduzido na região. O município atingiria o auge da produção em 1886 e conseguiria algum destaque nessa cultura até por volta de 1930, apesar da forte geada de 1918, que marcou o início do incremento da pecuária e da produção leiteira na região.

O núcleo urbano existente, até então, em função das relações com a economia agrária, passa pelas primeiras e mais significativas transformações na área urbanizada do município.

Segundo Santos (1993):

(...) esses fatores, todos agregados, parecem ter condicionado uma configuração espacial da área urbanizada em modelo concentrado, com especialização quase que exclusiva de centro administrativo e de ocupação residencial local, com tecido articulado em função dessa simplificação de funções.

\footnotetext{
${ }^{20}$ A Estrada Real foi criada pela Coroa portuguesa no século XVII com a intenção de fiscalizar a circulação das riquezas e mercadorias que transitavam entre Minas Gerais - ouro e diamante - e o litoral do Rio de Janeiro - capital da colônia por onde saíam os navios para Portugal. As estradas reais foram, ainda, os eixos principais do intenso processo de urbanização do Centro-Sul brasileiro. Ao longo do seu leito ou nas suas margens se distribuíram as centenas de arraiais, povoados e vilas em que se organizou a massa populacional envolvida com a economia da mineração e com as economias a ela associadas.
} 
A primeira metade do século $X X$, conhecida como Fase Sanatorial ${ }^{21}$, foi marcada por um processo de urbanização peculiar, mais especificamente, a partir da segunda metade dos anos 1920. O Sanatório Vicentina Aranha (Fig.2.6) é marco importante desta época.

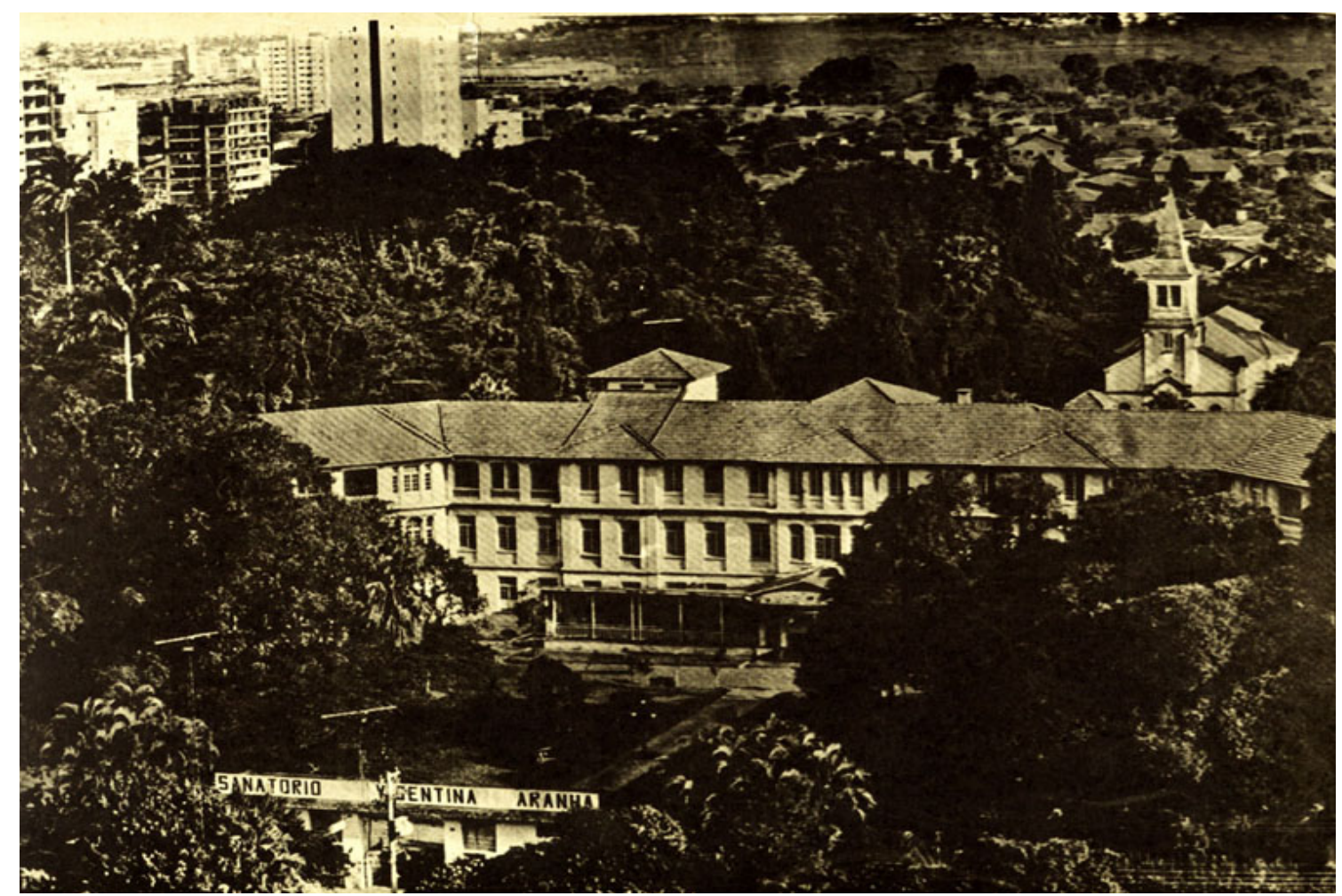

Figura 2.6 - Sanatório Vicentina Aranha e início da verticalização do seu entorno Fonte: P.M.S.J.C., 1970.

A Fase Sanatorial, em termos cronológicos, foi simultânea ao primeiro período do processo de industrialização de São José dos Campos. Não havia, nesses primeiros anos, basicamente até o final da primeira década do século $X X$, implantação industrial de porte, quer seja pela dimensão dos estabelecimentos, quer seja pela capacidade de produção e/ou pelo número de empregados.

O processo de industrialização do município teve início a partir da década de 20, quando houve ocorrência de um conjunto de fatores favoráveis à implantação de indústrias:

${ }^{21}$ Chamamos de Fase Sanatorial o período em que foram registrados o início, o auge e o declínio das atividades voltadas para o tratamento da tuberculose pulmonar no município de São José dos Campos, compreendido entre 1900 a 1958. A procura para o tratamento dessa doença foi devido às condições climáticas favoráveis dessa cidade. 
1) A situação geográfica favorável;

2) A concessão de incentivos fiscais;

3) A oferta de terrenos para a instalação de indústrias.

Em 1920, o então Prefeito Municipal, Coronel João Cursino, concedeu favores às indústrias que se instalassem em São José dos Campos. O objetivo dessa resolução era atingir capital fabril e geração de empregos, principalmente para as mulheres. As concessões traduziam-se em isenção de impostos, doação de terrenos e cessão das habitações aos empregados. Há nessa resolução a seguinte descrição:

(...) Se o proprietário de uma fábrica de 100 ou mais operários empregar operários desta cidade e seu município (principalmente mulheres) em número não inferior a um terço de todo pessoal, a Câmara lhe fará doação do terreno ocupado logo que se verifique que os operários do lugar se achem satisfeitos e tenham garantia de permanência em seus empregos. ${ }^{22}$

Os anos subseqüentes apresentaram-se para o município como os das primeiras grandes inovações no que se refere à produção - modos e meios desvinculados da cultura do café. Segundo Santos (1993), nesse período, a área urbanizada sofre pequeno reflexo dessas inovações, considerando-se que dois aspectos contribuíram para essa situação:

1) Parte da produção, de certa forma, ainda se localizava em zonas distantes da área urbanizada - setor rural extremamente dependente da disponibilidade da matéria prima - a mandioca - pelo transporte e manipulação.

2) Apesar de as novas formas de produção serem as maiores empregadoras de mão-de-obra, além de solicitarem certa especialização, não representavam fator de migração, e ainda que o fossem, as possibilidades de adensamento no que era então o intra-urbano parecem ter conseguido assimilar essa nova transformação.

\footnotetext{
${ }^{22}$ Jornal Correio Joseense, edição n ${ }^{0}$ 684, de 10 de maio de 1936.
} 
A partir de 1925, São José dos Campos já contava com algumas indústrias de cerâmica e tecelagem. Para Silva (2000), foi nesse período que as indústrias começaram a ser implantadas fora do núcleo central.

Na década de 20, a implantação do ramal Paratey levou ao deslocamento da estação ferroviária, fig. 2.7, da área próxima ao platô central para a área mais ao Norte, em direção ao fundo do vale do Rio Paraíba do Sul, próximo de onde se localizaria a Tecelagem Paraíba (1925), fig. 2.13.

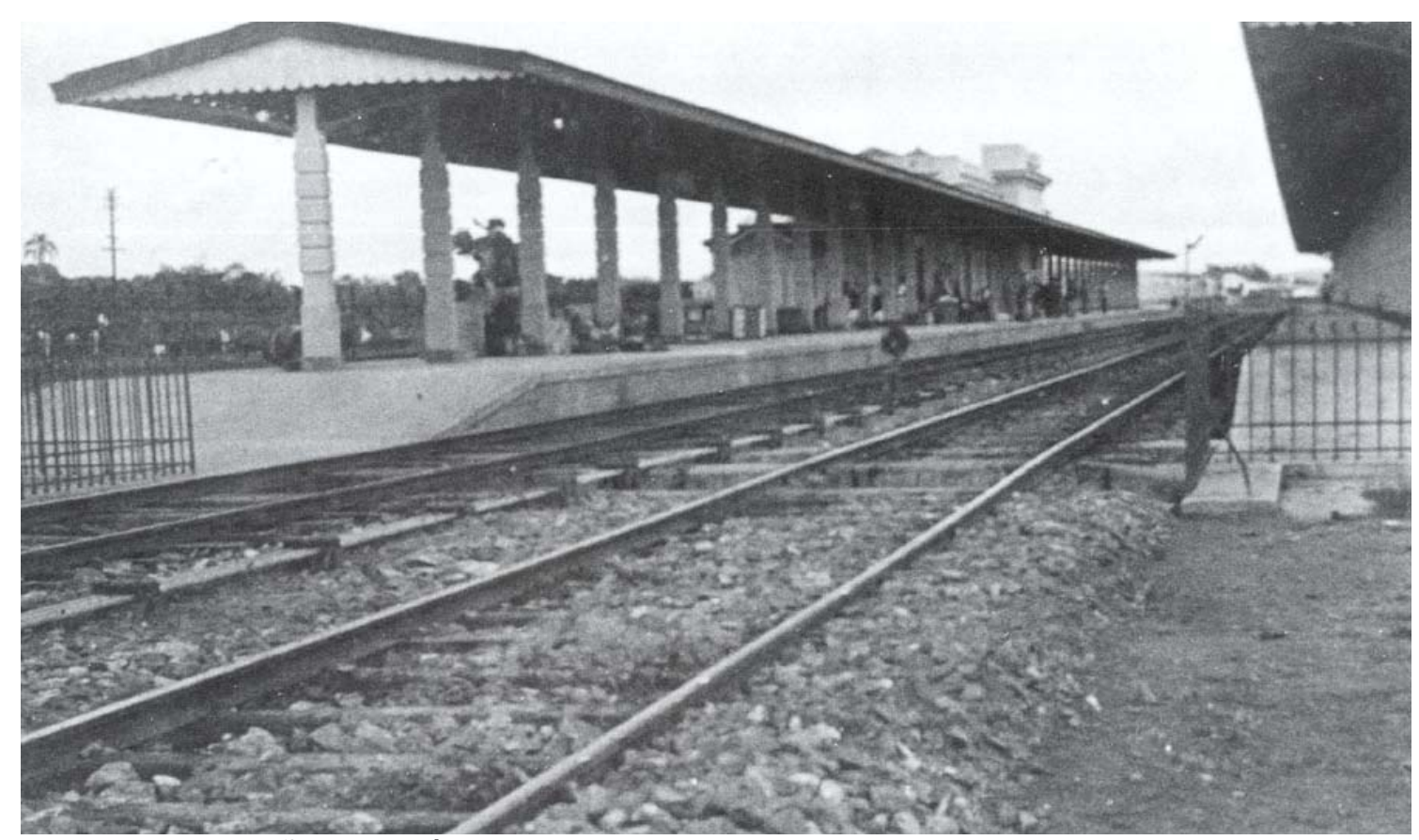

Figura 2.7 - Estação Ferroviária Fonte: PMSJC, s/d

Nessa mesma década, ocorreu a abertura da SP-50 que liga São José dos Campos a Campos do Jordão e Sul de Minas. A implantação reforçou a transposição e a ocupação da margem esquerda do Rio Paraíba em direção ao norte do município.

Em 1925, a falta de ordenamento urbano que vinha ocorrendo em São José dos Campos mereceu, do editor do jornal local, advertências às autoridades públicas para melhoramento do município, por meio de um plano de obras elaborado por higienistas, que sugeria, ainda, verbas do Estado para o aparelhamento da Estação de cura, diante da escassez de recursos municipais. 
Em 1928, é inaugurada a Rodovia Washington Luiz (antiga estrada velha Rio - São Paulo), configurando-se na primeira ligação rodoviária de grande distância do país, cortando o município mais ao Sul do platô central. Nesse período, verificamos que o eixo marcante de expansão foi no sentido Nordeste / Sudoeste. Esse eixo foi marcado pelo traçado do rio Paraíba do Sul e pela construção da ferrovia e da rodovia.

Até então, a legislação de controle e ocupação do solo era restrita a uma distribuição de atividades no território muito preliminar e genérico.

Neste primeiro período, portanto, a legislação urbanística para o controle de ocupação do espaço se fazia em nível de legislação edilícia, com a exigência de numeração das casas e logradouros, com a preocupação pelo alinhamento em relação aos passeios e alargamentos das vias centrais. Pudemos verificar que já havia uma política de incentivos fiscais para implantação de indústrias nesse município.

\subsubsection{Segundo período de 1930 A 1950}

No início da década de 30, Era Vargas, o perímetro urbano de São José dos Campos ocupava uma área de aproximadamente $5 \mathrm{~km}^{2}$. A área central concentrava a maioria das edificações que era composta por ruas estreitas e empoeiradas ${ }^{23}$.

Nesse período a precariedade urbana vivida pela população de São José dos Campos era notada pela falta d'água, deficiência de coleta de esgotos, mendicância, sujeira e profunda promiscuidade entre sadios e infectados pela tuberculose.

Este quadro caótico contrariava as propagandas dos loteadores imobiliários. Um novo loteamento foi anunciado em 1926 e seus proprietários o batizaram com uma denominação atrativa: "Vila Progresso".

A interferência da Interventoria nas ações das administrações municipais foi nitidamente notada na seguinte medida de autoria do Prefeito Coronel José Domingues de Vasconcellos, em março de 1932. Sob alegação de resguardar a estética da cidade,

\footnotetext{
${ }^{23}$ Jornal Correio Joseense, edição n 630, 16 de junho de 1935.
} 
evitar a promiscuidade entre tuberculosos e sadios e, também, destinar um espaço específico da cidade para a instalação de pensões sanatoriais e sanatórios, o administrador determinou que a Estação Climática fosse dividida em três zonas territoriais $^{24}$ : Comercial, Sanatorial e Residencial. Esse Ato foi levado e submetido à aprovação do departamento da Administração Municipal, órgão vinculado à Interventoria Federal. Além disso, de acordo com aquela repartição, a zona urbana dividiu-se em quatro zonas: Industrial, Comercial, Sanatorial e Residencial ${ }^{25}$.

A topografia privilegiada da Zona Sanatorial, delimitada em 1933, e sua proximidade do núcleo urbano fizeram com que surgissem alguns loteamentos residenciais para atender a uma população de melhor renda e que incentivou um processo de especulação imobiliária.

No início dos anos 30, a Estância Climática de São José dos Campos passava por uma profunda transformação urbana. A divisão da cidade, em zonas, passava por retificações dos traçados de várias ruas do centro, exemplo de interferências que passaram por prefeitos, cuja formação era de engenheiros sanitários ou médicos que eram nomeados pelo governo estadual. A ação intervencionista implementada por esses prefeitos guardava similaridades com as ações executadas nesse início do século XX, no Rio de Janeiro, pelo Engenheiro Pereira Passos e pelo Sanitarista Oswaldo Cruz.

Para a Zona Urbana, foram previstos lotes em grandes dimensões para uma melhor ventilação e insolação. Essa visão de amplos terrenos para edificação foi efetivamente adotada na Zona Sanatorial, em dezembro de 1933.

O chefe do poder executivo, o Engenheiro Leovigildo Trindade, determinou que os lotes nas zonas urbana e suburbana deveriam ter área mínima de $1.000 \mathrm{~m}^{2}$. Os

\footnotetext{
${ }^{24}$ Surgido em fins do século XIX na Alemanha, o zoneamento atinge sua maturidade disciplinar no período pós-primeira guerra e, a partir dai, se expande para quase todos os países. Sua primeira e mais significativa exportação são para os Estados Unidos, onde após a adoção da primeira lei abrangente ao conjunto da cidade, em 1916, em Nova York, adquire características particulares (FELDMAN, 1996).

${ }^{25}$ São Paulo. Departamento da Administração Municipal, Ofício nº 11244, 08 de junho de 1932.
} 
lotes destinados às zonas operárias deveriam ter área mínima de $300 \mathrm{~m}^{2}$ e na zona rural os lotes não poderiam ter área inferior a $1.500 \mathrm{~m}^{226}$.

Nesse mesmo ano, por força do Decreto Estadual $n^{0} 7.007$, de 12 de março de 1935, São José dos Campos foi elevada à condição de Estância Climática e Hidromineral $^{27}$. Por esse decreto, as receitas da Estância seriam constituídas pelas arrecadações municipais destinadas à manutenção administrativa e as receitas oriundas da arrecadação estadual seriam aplicadas em serviços públicos.

Sucedendo o Engenheiro Leovigildo Trindade assumiu, em 20 de setembro de 1937 o Prefeito Sanitário Edgar Melo Matos de Castro. Em sua gestão não ocorreram intervenções urbanas significativas.

Foi, no entanto, na gestão de seu sucessor, o Engenheiro Francisco José Longo, a partir de junho de 1938, que São José dos Campos passaria pelas mais significativas transformações urbanas.

Essas transformações decorreram do estreito relacionamento entre o Interventor Federal Adhemar de Barros e o Prefeito Francisco José Longo para que fossem feitas dotações orçamentárias necessárias para viabilizar um plano de obras urbanísticas de porte, como a construção de uma rede para a distribuição de água potável e, principalmente, a desapropriação dos imóveis do lado par da Rua São José para a futura construção de uma avenida que contornasse a orla do banhado. (Fig. 2.8)

\footnotetext{
${ }^{26}$ São José dos Campos, Ato Municipal $\mathrm{n}^{\circ}$ 224, 26 de dezembro de 1933.

${ }^{27}$ O que torna significativa a condição de Estância Climática e Hidromineral que a cidade assumia por decreto, dentre outros fatores, foi a possibilidade de dotação de verbas vindas do fundo de participação das Estâncias e essas verbas possibilitaram não só ensaios de Plano Diretor de numerosas cidades, mas também, no caso de São José dos Campos, a urbanização, principalmente no setor de infra-estrutura de saneamento, em uma época como a depressão da segunda guerra mundial, quando os recursos eram escassos para a maioria das cidades.
} 


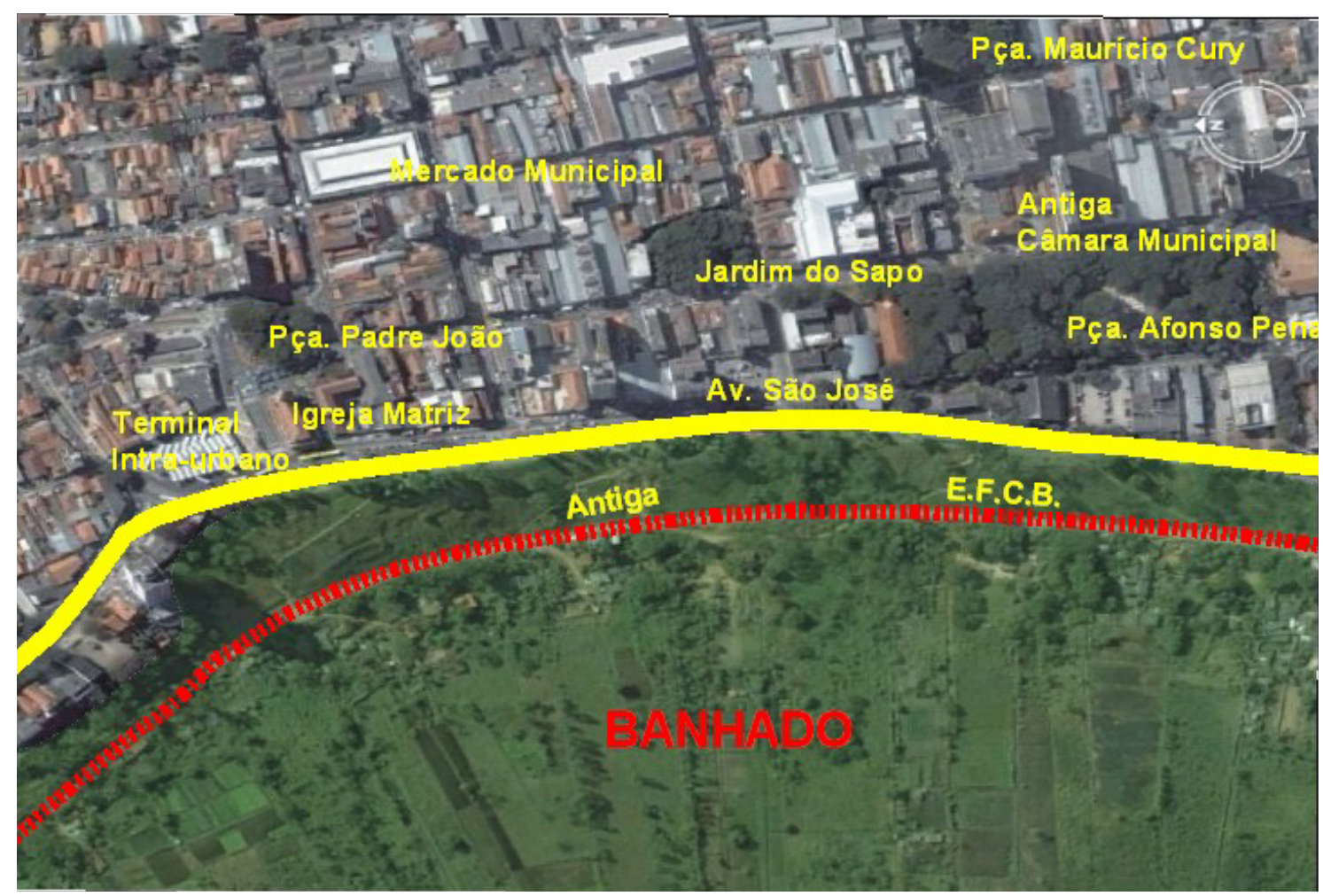

Figura 2.8 - Avenida São José e orla do Banhado na Região Central.

Fonte: Google Earth, 2006.

Nesse mesmo período, o poder Executivo fixou novos limites para os perímetros urbano e rural e uma nova subdivisão para o zoneamento territorial que envolveria as quatro zonas já definidas.

Em conseqüência dessa diretriz, a Zona Sanatorial foi ampliada, anexando-se ao espaço compreendido pelo Campo do Putim, cerca de $12.000 .000 \mathrm{~m}^{2}$ que, posteriormente, foi doado ao Ministério da Aeronáutica para fins de implantação do atual Centro Técnico Aeroespacial. ${ }^{28}$

Essa gleba de terras viria a se tornar, mais tarde, um grande obstáculo de transposição e de circulação viária entre os bairros da Zona Sul do município, pois o CTA dificulta a interligação da Região Sul e, a Sudeste citamos a área da Refinaria Henrique Lage. Estas áreas impossibilitam a transposição e a circulação entre os bairros situados na Região Leste e Sudeste do município. (Fig. 2.9)

\footnotetext{
${ }^{28}$ São José dos Campos, Ato Municipal n ${ }^{\circ}$ 14, 11 de outubro de 1938.
} 


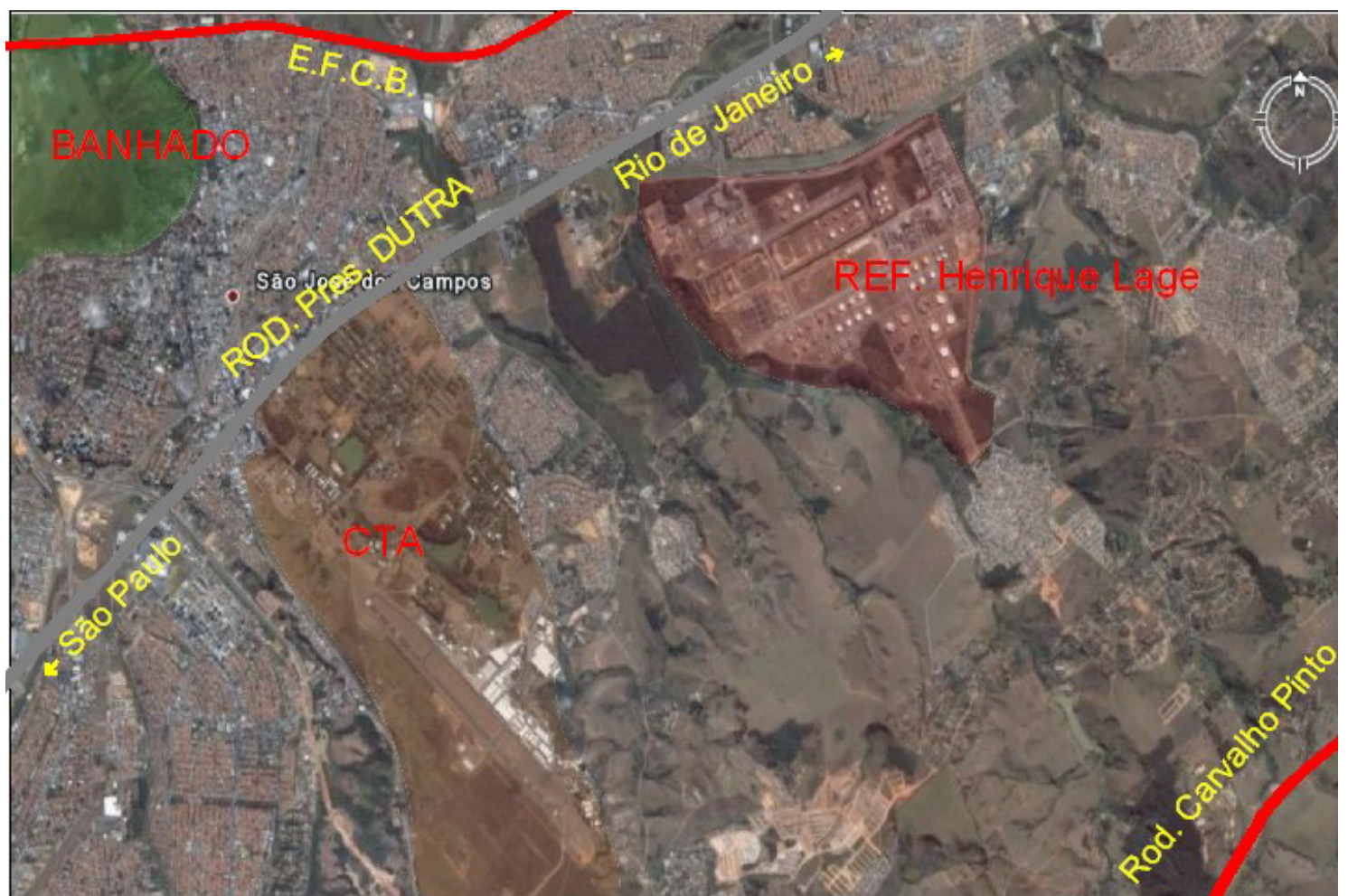

Figura 2.9 C.T.A. e Refinaria Henrique Lage Fonte: Google, 2006.

O problema de circulação entre as regiões que compõem o território de São José dos Campos, fruto da falta de articulação entre as diretrizes urbanísticas locais e as estatais é, até hoje, um grave problema de interligação do município.

A partir de 1942, na administração de Pedro Popini Mascarenhas, foram intensificadas desapropriações, a maioria para retificar traçados de vias centrais. São José dos Campos passou a ter um traçado pautado pela continuidade espacial, quadras regulares e vias amplas e ortogonais.

Nesse período e ao contrário das outras cidades do Vale do Paraíba, São José dos Campos começava a se diferenciar de suas vizinhas, com ruas amplas, ensolaradas, arborizadas e arejadas. São José dos Campos estava rompendo com a imagem de uma cidade empoeirada e com traçado colonial do século XIX para adquirir uma nova imagem de cidade moderna do século XX. (Fig. 2.10) 


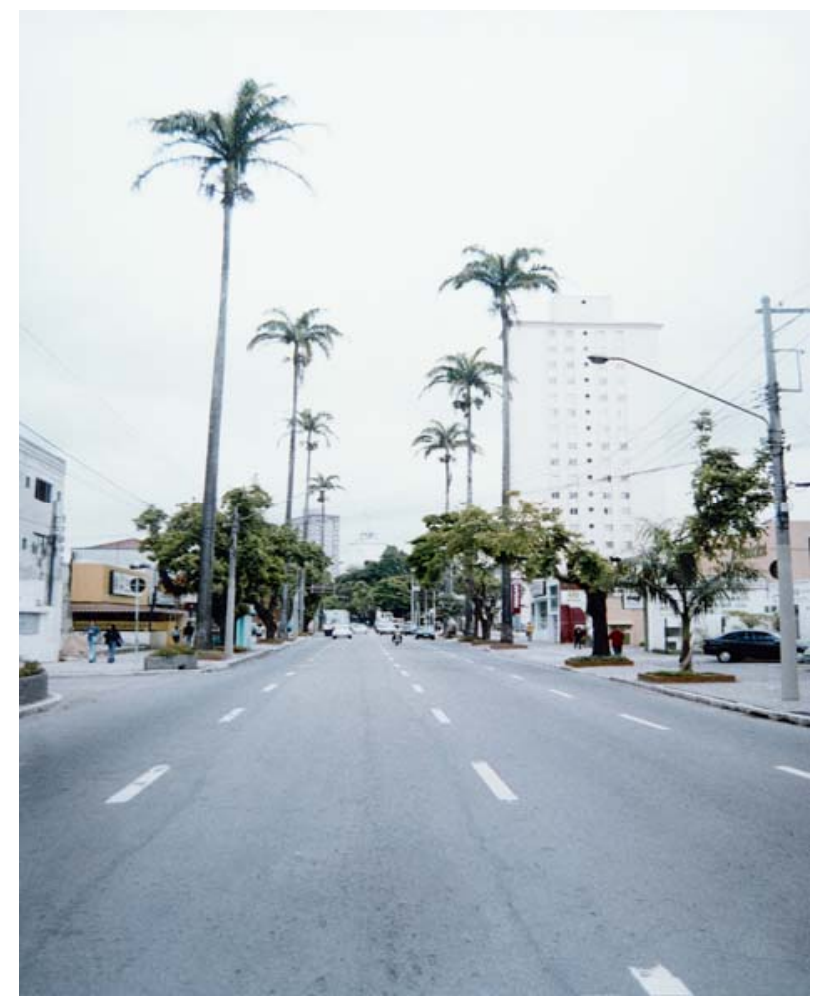

Figura 2.10 - Avenida João Guilhermino e as Palmeiras Imperiais Fonte: P.M.S.J.C., s/d

Destaca-se, nesse período, a aprovação de um projeto para um loteamento baseado nos conceitos de uma cidade-jardim que teve como inspiração, o movimento iniciado na Inglaterra, por Ebenezer Howard: os atuais Jardim Nova América, Jardim Europa e Jardim Esplanada I. Esses espaços privilegiados localizam-se entre as Avenidas São João e Borba Gato, incrustados na Zona Sanatorial.

Os loteamentos eram compostos internamente por ruas verdes e seu desenho orgânico e planejamento paisagístico, aspectos fundamentais desse ideário, foram considerados avançados para a época. Assim como o primeiro projeto de bairro com características de cidade-jardim, em São Paulo, o Jardim Nova América, esses foram implantados para uma população de alta renda de São José dos Campos. (Fig. 2.11) 


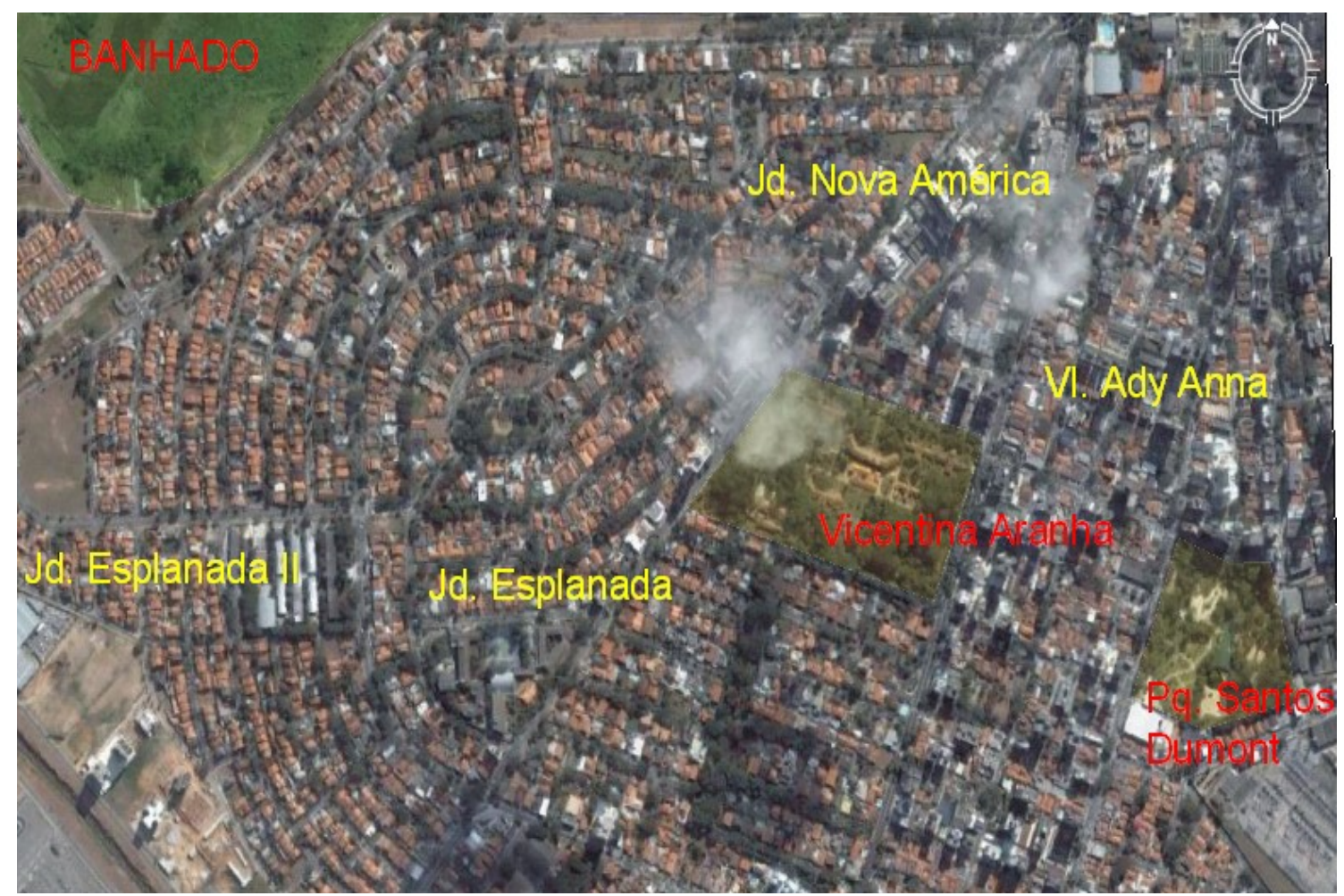

Figura 2.11 Jardim Nova América e Esplanada I e II - SJC

Fonte: Google, 2006.

A administração de Elmano Ferreira Veloso, empossado por nomeação, substituiu a de Antenor Nascimento Filho, em 17 de fevereiro de 1949. Sua primeira medida administrativa tinha como objetivo atrair capital fabril têxtil e trouxe repercussões diretas no espaço urbano joseense: a concessão de terreno de propriedade pública, medindo 90.000,00 $\mathrm{m}^{2}$ para a Companhia Rhodosá de Raion Sociedade Anônima. ${ }^{29}$ (Fig. 2.12)

A implantação dessa indústria, ao Norte do município, foi um dos indutores do transbordamento dos limites de expansão urbana que já vinha ocorrendo desde 1925, quando foi inaugurada a Tecelagem Parahyba.

${ }^{29}$ São José dos Campos, Lei Municipal n 38, 10 de março de 1949. 


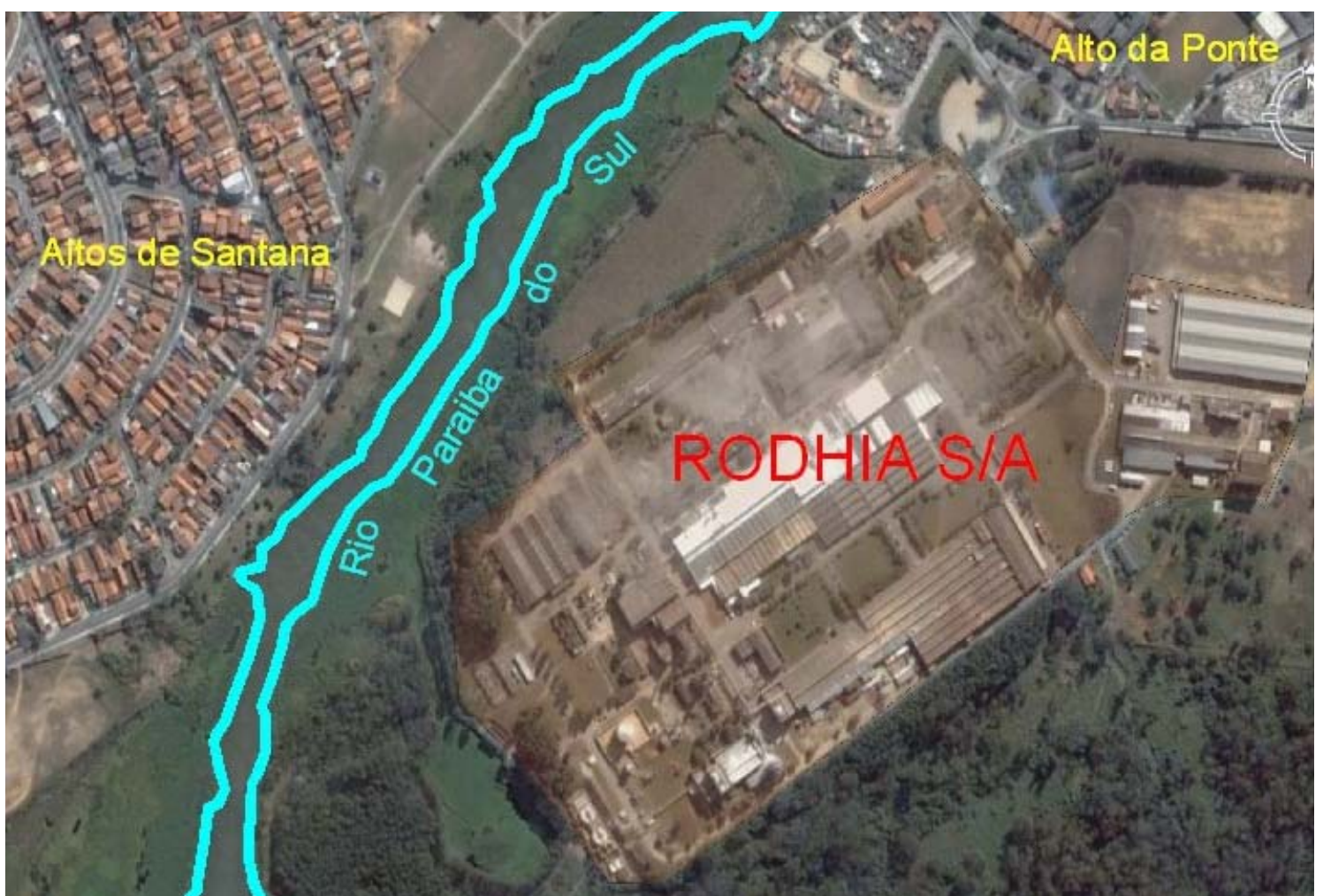

Figura 2.12 - Rhodia S.A.

Fonte: Google, 2006

A instalação da multinacional francesa, às margens do Rio Paraíba do Sul no bairro de Santana, fez com que famílias de origem européia viessem morar em São José dos Campos. Esses novos habitantes tinham nível socioeconômico mais elevado do que a população da cidade, o que provocou um aumento geral nos custos de habitação e nos preços dos gêneros de primeira necessidade. Muitos desses trabalhadores se instalaram nos Jardins América, Europa e Esplanada I. Esse fato também foi notado quando da instalação da General Motors ${ }^{30}$ dez anos mais tarde.

Para se compreender o nível a que chegou a especulação fundiária iniciada em 1948, uma matéria jornalística chamava a atenção para os exploradores do crescente mercado imobiliário joseense. A imprensa local destacava que os terrenos

\footnotetext{
${ }^{30}$ São José dos Campos, Plano Diretor do Município de São José dos Campos: Plano Preliminar, 1961, p.56.
} 
comercializados em São José dos Campos eram caros e desprovidos de benfeitorias públicas. ${ }^{31}$ Muitos loteamentos eram comercializados sem a infra-estrutura necessária.

Com a intenção de controlar a especulação imobiliária, em junho de 1949, o Poder Público promoveu a retração da Zona Sanatorial e ampliou a Zona Residencial incluindo o perímetro que abrange o atual Jardim São Dimas. ${ }^{32}$ Desta forma, acreditavase que, aumentando a oferta, o preço da terra poderia vir a se estabilizar e tornar-se acessível à população.

Sobre a distribuição espacial da urbanização nos anos 40, podemos dizer que essa teve características de tecido misto - serviços, comércios, residências e uma forte presença quanto ao porte e localização intra-urbana, de instalações industriais.

A política adotada nesse período, pelo governo federal, privilegiava o incentivo e a participação estatal - direta ou indireta - na implantação, principalmente, da indústria de base (siderurgia, cimento, etc.) e na ampliação e consolidação da rede de transportes.

A década de 40 correspondeu a um período de intensas modificações estruturais do parque industrial brasileiro e, em particular, do paulista. É nessa década que a dinâmica produtiva de São José dos Campos passa a ser mais diversificada no setor industrial. Podemos notar essa diversificação, ainda que tímida, se considerarmos que, até o final dos anos 30, a cidade dispunha de seis estabelecimentos de torrefação e moagem de mandioca na Zona Rural, uma de fiação e tecelagem na Área Urbana e um estabelecimento de laticínios e derivados, na área urbanizada do município.

Ao final dos anos 40, São José dos Campos tinha, na área urbana, as seguintes atividades industriais: uma de fios e fibras sintéticas - RHODIA, duas de laticínios e derivados, uma de torrefação e moagem e um estabelecimento de artigos de limpeza.

\footnotetext{
31 Jornal Correio Joseense, edição de 12 de julho de 1948.

${ }^{32}$ São José dos Campos, Lei Municipal n ${ }^{\circ}$, 06 de junho de 1949.
} 
Em junho de 1949, também foi criada uma Comissão de Organização do Centro Técnico Aeroespacial (COCTA) ${ }^{33}$, depois extinta em novembro de 1953, quando foi criado oficialmente o Centro Técnico Aeroespacial - CTA. ${ }^{34}$ Seu objetivo foi de implantar o núcleo inicial para estimular a indústria aeronáutica brasileira e de uma escola de engenharia aeronáutica, sendo escolhida a cidade de São José dos Campos por sua localização estratégica entre os grandes centros brasileiros Rio e São Paulo.

A instalação do Centro Técnico da Aeronáutica - CTA, em 1950, projetado pelo arquiteto Oscar Niemeyer, foi inspirado no modelo americano do MIT (Instituto de Tecnologia de Massachussets).

Temos, portanto, até a década de 50 um maior desenvolvimento urbano nas regiões periféricas do núcleo original em direção ao Norte da cidade, onde se instalaram as primeiras grandes indústrias (Tecelagem Parahyba - Fig. 2.13 e Rhodia).

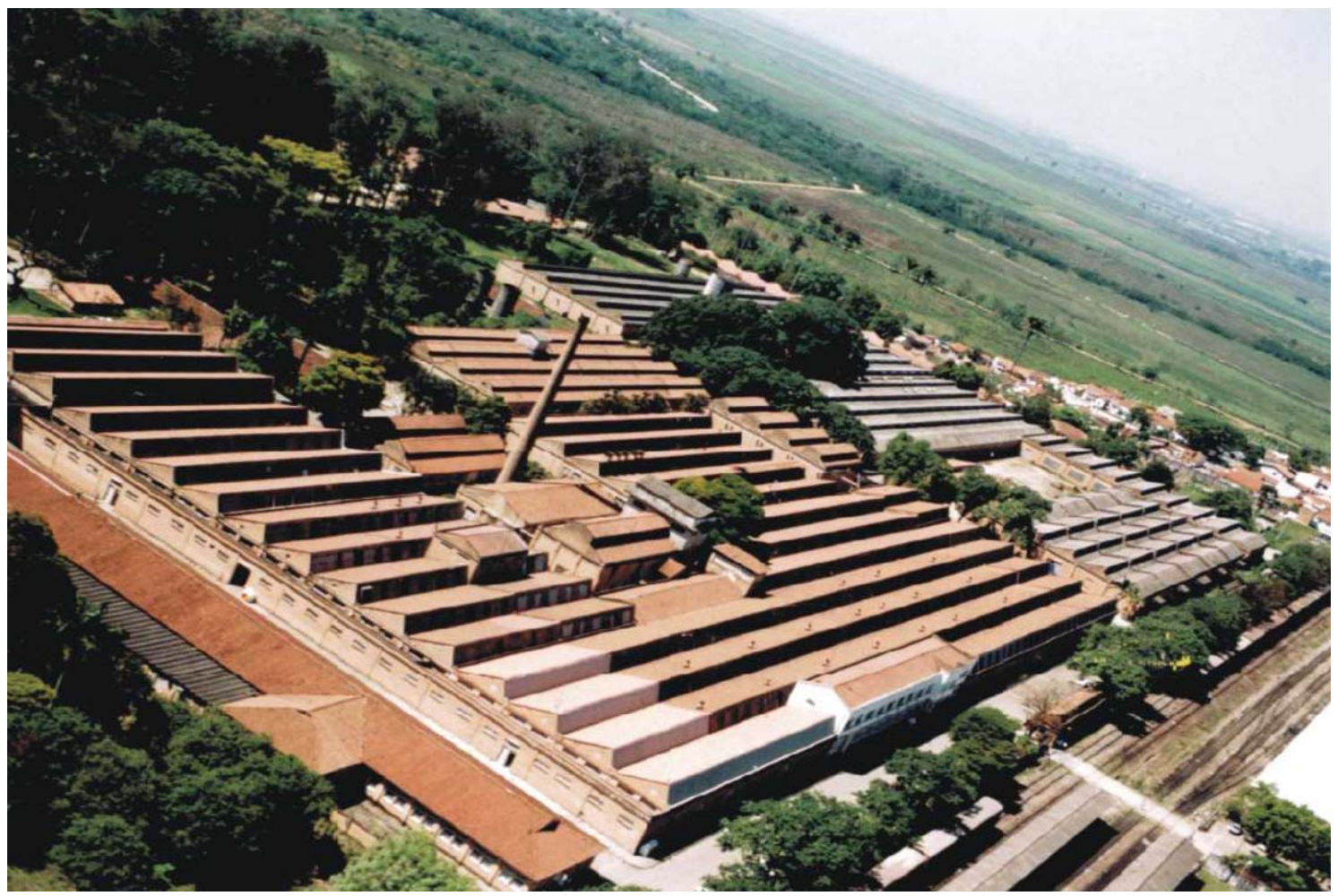

Figura 2.13 - Complexo da Tecelagem Parahyba Fonte: P.M.S.J.C., s/d.

\footnotetext{
${ }^{33}$ Decreto Federal $\mathrm{n}^{\circ} 26.509,25$ de março de 1949.

${ }^{34}$ Decreto Federal $n^{0} 34.707,26$ de novembro de 1953.
} 


\subsubsection{Terceiro período: 1950 até 1970}

Os anos 50 podem ser considerados o marco referencial da industrialização contemporânea e da dinamização da urbanização em São José dos Campos.

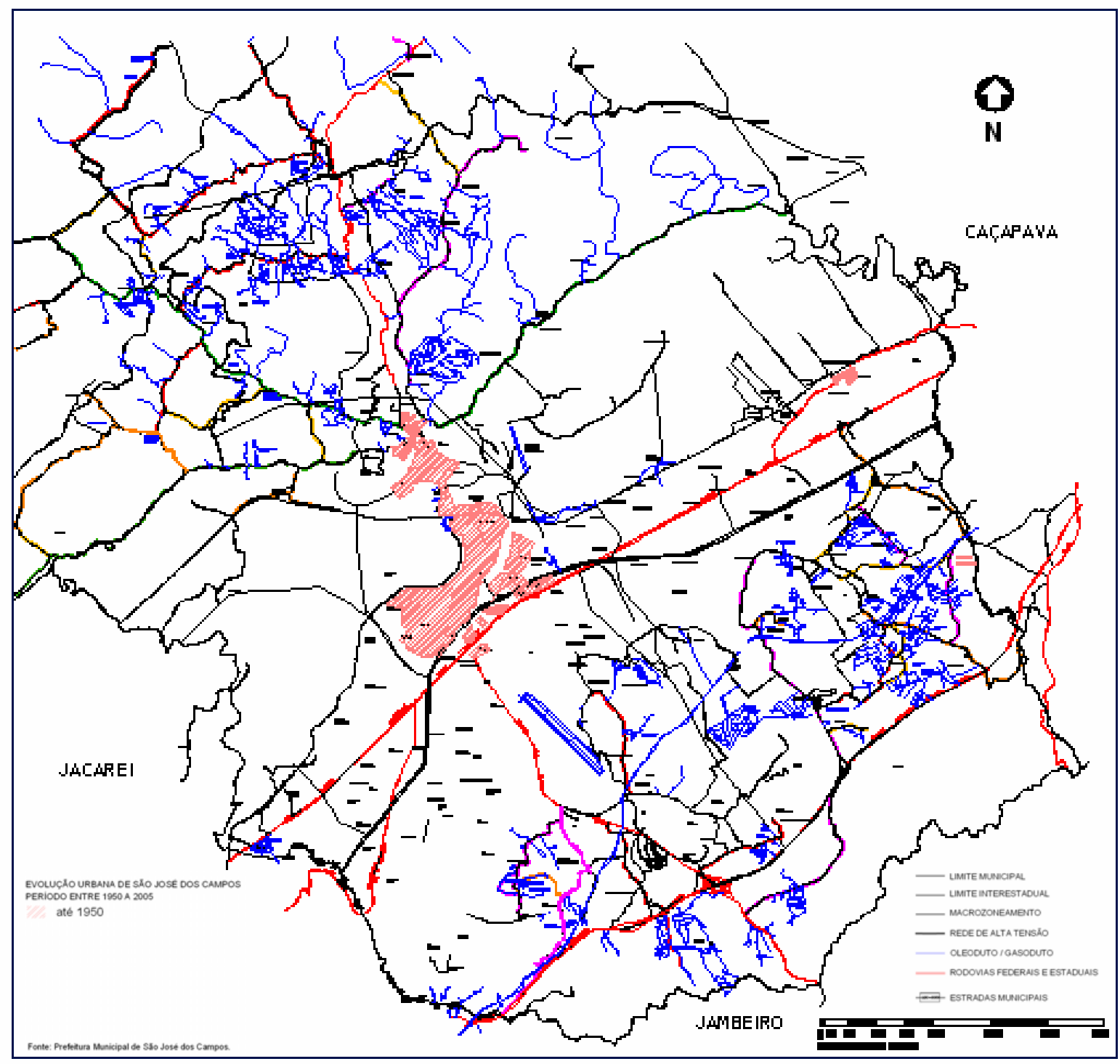

Figura 2.14 - Mapa evolução urbana até 1950 Fonte: PMSJC, 2006.

A distribuição da população de São José dos Campos em 1950 era de 44.804 habitantes, sendo 26.600 na Zona Urbana e 18.204 na Zona Rural e comprovava o acelerado processo de crescimento urbano que vinha ocorrendo nesse município. 
Tabela 2.10 - Evolução populacional do Município - 1940-2000

\begin{tabular}{|l|c|c|c|}
\hline \multicolumn{3}{c}{ POPULAÇÃO } \\
ANO & TOTAL & URBANO & RURAL \\
\hline 1940 & 36.279 & 14.474 & 21.805 \\
1950 & 44.804 & 26.600 & 18.204 \\
1960 & 77.533 & 56.882 & 20.651 \\
1970 & 148.332 & 132.482 & 15.850 \\
1980 & 287.513 & 276.901 & 10.612 \\
1991 & 442.370 & 425.515 & 16.855 \\
2000 & 539.313 & 532.717 & 6.596 \\
\hline
\end{tabular}

Fonte: Censos demográficos 1940 a 2000 - IBGE.

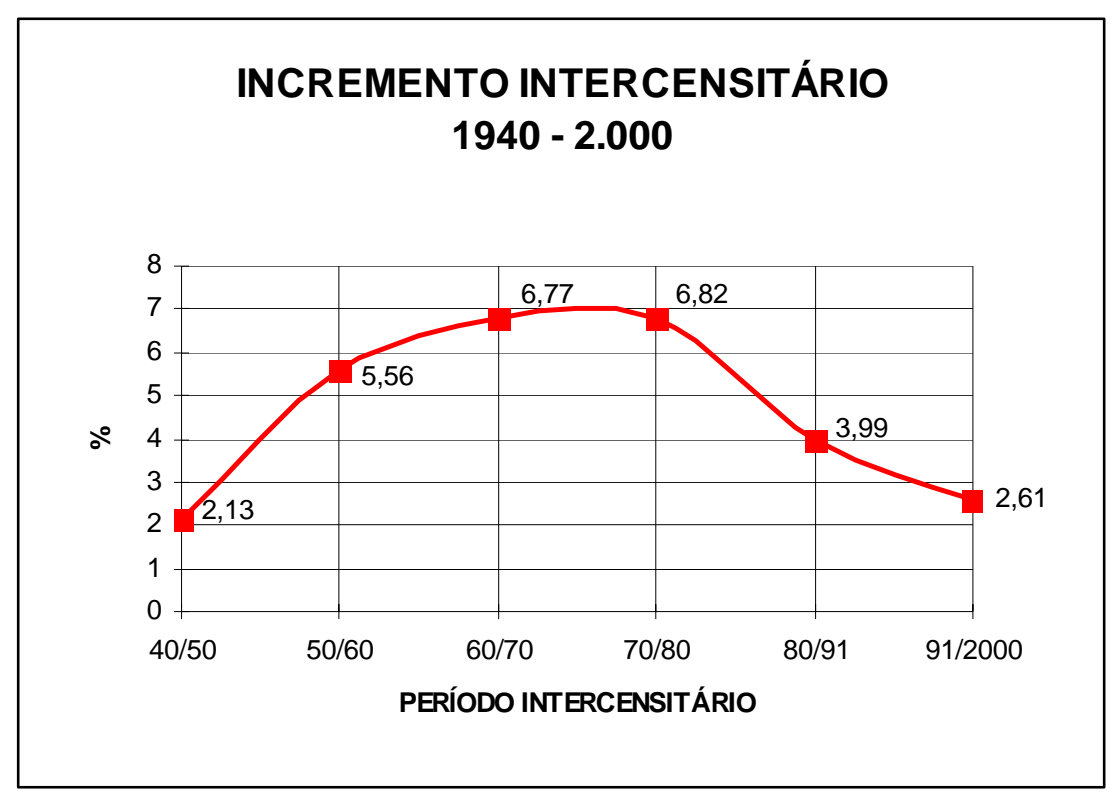

Figura 2.15 - Gráfico Incremento Intercensitário 1940 - 2000 Fonte: IBGE Censos Demográficos 1940 - 2.000.

A partir dessa constatação foram estimuladas medidas para solucionar alguns problemas decorrentes desse processo, como o da habitação. Assim, em abril de 1951, foi criado pelo prefeito Tertuliano Delfim Júnior, o Departamento da Casa Popular ${ }^{35}$, vinculado à Prefeitura Sanitária, que previa um número ilimitado de adesões das camadas de baixa renda ao projeto de casa popular e objetivava criar uma rede de compradores de residências populares por meio da mutualidade.

\footnotetext{
${ }^{35}$ São José dos Campos, Lei Municipal n 108, 09 de abril de 1951.
} 
Posteriormente, o poder público criou o Serviço de auxílio à Construção Popular, no qual se previa oferecer loteamentos sob responsabilidade da Prefeitura, assistência técnica à construção e principalmente a revenda dos imóveis em pagamentos parcelados. $^{36}$

Em 19 de janeiro de 1951, acelerou-se o desenvolvimento industrial, com a inauguração de um novo traçado para a Rodovia Presidente Dutra, mais ao Sul do município. Esse traçado criou um novo eixo de expansão e polarização, quando indústrias de porte se instalaram. Essas indústrias ocupavam extensas glebas, com edificações de porte correspondente às novas exigências de produção e que, em associação à área do CTA, se configuraram como um cinturão entre a rodovia e a área urbanizada. Esta ocupação desordenada viria a ser objeto de estudo específico do Plano Preliminar, elaborado mais tarde, pelo CEPEU - USP.

A Rodovia Presidente Dutra apresentava-se como um divisor, uma barreira à transposição e elemento de interrupção de tecidos e de morfologias no território da cidade.

Com o intuito de atrair o capital industrial, foi promulgada, em abril de 1952, uma lei que isentava de impostos municipais as indústrias que se instalassem em São José dos Campos. ${ }^{37}$ Essa lei teve importância fundamental e atraiu novas indústrias para a cidade. O incentivo fiscal oferecido pelo município totalizava um prazo de isenção de cinco anos dos impostos municipais às fábricas com mais de 30 operários. Numa progressão, as fábricas que empregassem mais de 500 operários eram isentas por 15 anos do pagamento desses impostos. O período de isenção vinculava-se ao volume de capital empregado para a instalação fabril e quantidade de operários da empresa.

\footnotetext{
${ }^{36}$ São José dos Campos, Lei Municipal n ${ }^{0}$ 194, 06 de dezembro de 1952.

${ }^{37}$ São José dos Campos, Lei Municipal n 155, 14 de abril de 1952.
} 
O Executivo Municipal, utilizando a mesma vinculação com o número de operários e período de isenção fiscal, também isentou do imposto predial urbano as fábricas já instaladas que ampliassem suas instalações. ${ }^{38}$

Em 11 de janeiro de 1954, o Prefeito Benoit Almeida Vitoretti publicou a Lei Municipal 381, que institui o primeiro Código de Obras. Neste documento podemos destacar disposições que mais tarde vieram demonstrar o seu alcance, como os artigos 169, capítulo VIII: "Nos bairros industriais, a ocupação do lote não poderá ultrapassar 70\% da área total, destinando o restante às áreas verdes."

O Código de Obras, além de conter diretrizes e normas para edificações também continha a primeira tentativa de ordenação do território de São José dos Campos, que também trouxe como benefício, o Artigo 202, do mesmo capítulo que propunha: "Ao longo dos cursos de água será sempre reservada uma faixa para sistema de park-way, cuja largura será fixada pela prefeitura."

A importância desse artigo trouxe benefícios que permanecem até hoje, pois grandes áreas de vegetação no município, pertencem às indústrias de grande porte as quais tiveram que cumprir as disposições dessa diretriz. Como exemplo, podemos citar os bosques da Johnson e Johnson's, o da General Motors do Brasil e a massa de plantação de pinus da Kodak do Brasil. (Fig. 2.16 e 2.17)

\footnotetext{
${ }^{38}$ São José dos Campos, Lei Municipal n 243, 02 de setembro de 1953.
} 


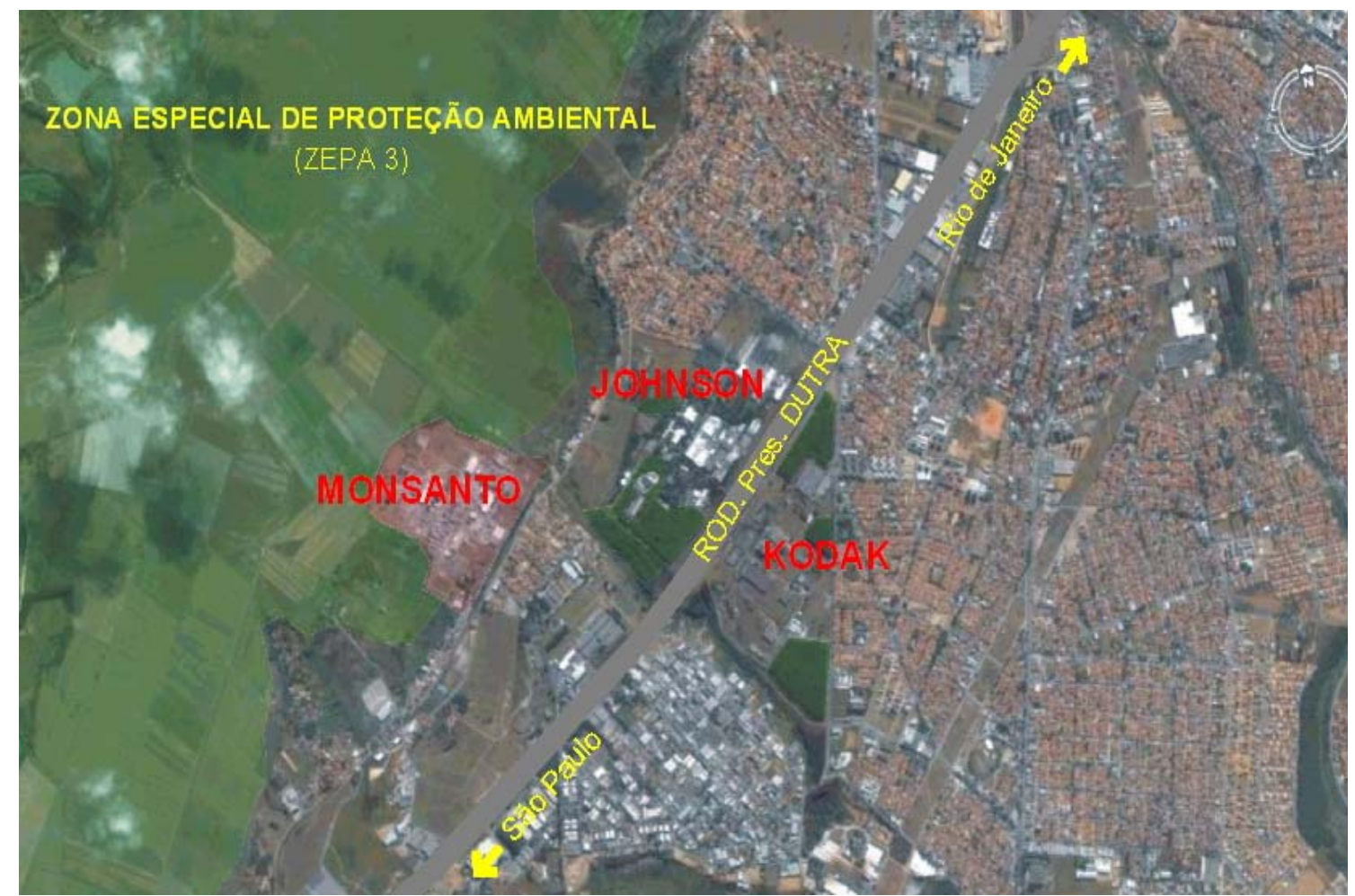

Figura 2.16 - Bosque da Johnson's e plantação de pinheiros da Kodak.

Fonte: Google Earth, 2006.

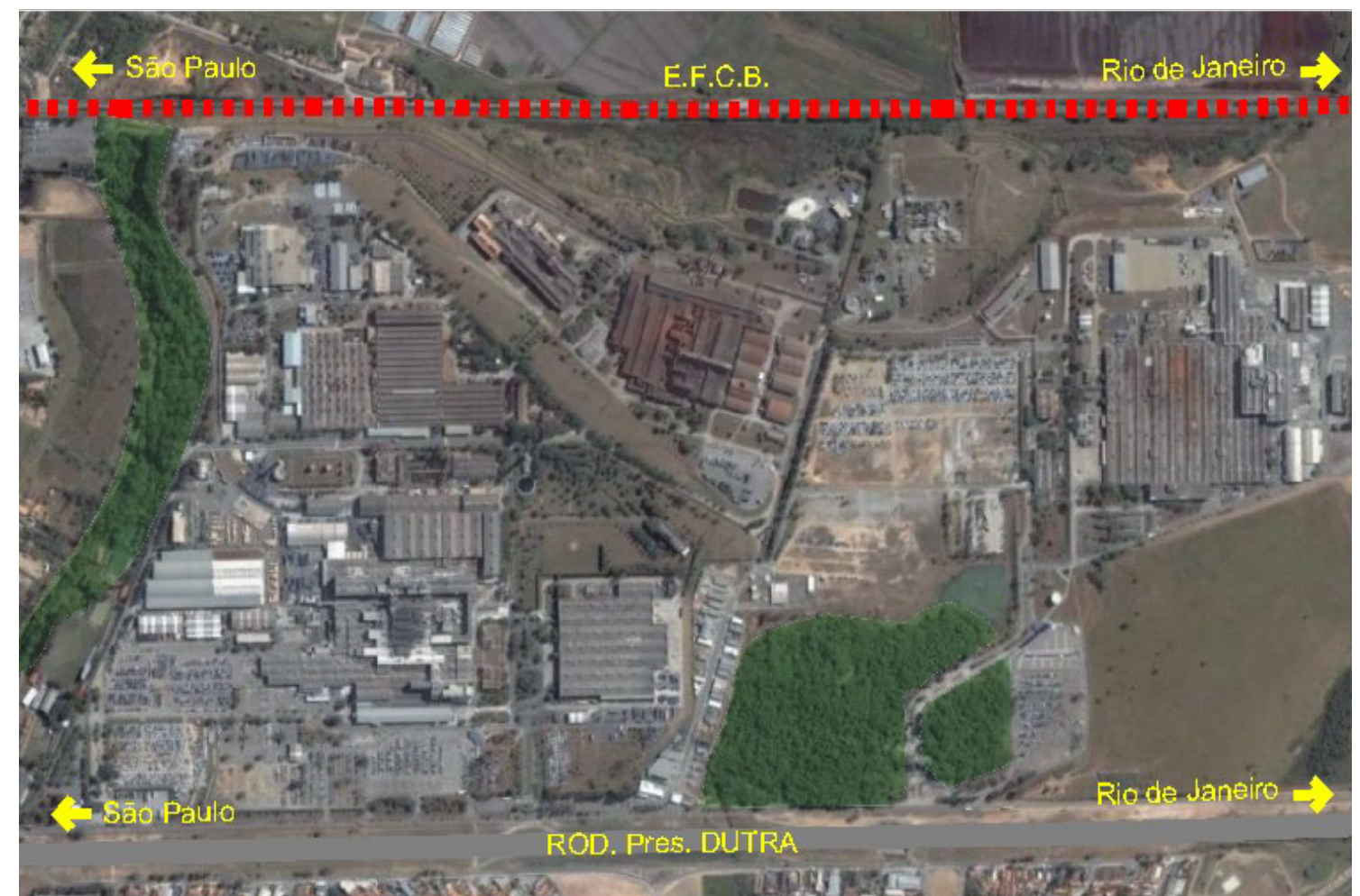

Figura 2.17 - Bosque da General Motors do Brasil

Fonte: Google Earth, 2006. 
Essa lei viria a ser revogada em sua edição de 1968, devido a um novo Código de Edificações elaborado em função dos estudos para o Plano Diretor pelo escritório do Arquiteto Jorge Wilheim.

Pela segunda vez à frente do Executivo Municipal em 24 de fevereiro de 1955, Elmano Ferreira Veloso promoveu expressivas intervenções urbanísticas na cidade.

Atendendo às aberturas e ocupação de novos loteamentos e a crescente expansão industrial e demográfica, a Administração Pública determinou, em abril de 1955, a revisão periódica dos perímetros das zonas e dos bairros ${ }^{39}$.

Como conseqüência dessas revisões, foi proposta a desativação de parte da Zona Sanatorial, que já vinha ocorrendo desde a década de 50, transformando-a em Zona Residencial. Essa zona passou a ser o anseio dos especuladores que vislumbravam maiores lucros sobre as transações imobiliárias.

A valorização imobiliária da Zona Residencial fez com que o Poder Público elaborasse a proposta de uma nova delimitação para o zoneamento de seu território. Como decorrência, houve nova proposta para delimitar o perímetro urbano por parte do Executivo municipal ${ }^{40}$.

Além dessa valorização, começou a ocorrer a concentração de instalações comerciais na área legalmente definida como Zona Residencial, em 1957. Como conseqüência, uma parcela da Zona Sanatorial foi incorporada posteriormente pela Zona Comercial $^{41}$. Nesse final da Fase Sanatorial, a medida em que essa ia se tornando menos interessante - já não vinham mais doentes para a cidade - a Zona Sanatorial vai sendo repartida e incorporada às Zonas Residencial e Comercial.

O Prefeito Elmano Ferreira Veloso foi sucedido por Donato Mascarenhas Filho em 11 de abril de 1958, administrador que ocupou a última gestão de Prefeitos ditos

\footnotetext{
${ }^{39}$ São José dos Campos, Lei Municipal n ${ }^{\circ}$ 346, de 19 de abril de 1955.

${ }^{40}$ São José dos Campos, Lei Municipal $\mathrm{n}^{\circ}$ 90, 08 de setembro de 1950

${ }^{41}$ São José dos Campos, Lei Municipal n 516, de 30 de outubro de 1957.
} 
Sanitários. Uma semana depois, no Palácio do Governo, foram celebrados os primeiros convênios para o planejamento dos municípios declarados como estâncias hidrominerais, criado pela Lei Orgânica dos Municípios, em 18 de setembro de 1957. As primeiras estâncias contempladas foram: Águas da Prata, Santa Rita do Passa Quatro, Socorro, Campos do Jordão e São José dos Campos.

Uma das principais medidas do Executivo para o início dos trabalhos de elaboração do primeiro Plano Diretor de São José dos Campos foi a criação de uma Comissão, orientada pelo Centro de Pesquisas e Estudos Urbanísticos da Faculdade de Arquitetura e Urbanismo da Universidade de São Paulo ${ }^{42}$. Sua principal característica foi preparar a cidade para enfrentar os efeitos negativos da industrialização vertiginosa, anunciada pela Via Dutra e pela construção de indústrias de grande porte.

Esse primeiro Plano Diretor de São José dos Campos foi produto de um convênio entre a USP, o Departamento de Obras Sanitárias e a Municipalidade. Gerou-se nesse processo um relatório detalhado sobre o perfil de São José dos Campos, instrumentalizando o poder Público, a partir desse momento, para gerar a legislação específica. A oficialização da Comissão do Plano Diretor deu-se por meio do decreto $\mathrm{n}^{\mathrm{o}}$ 246 de 10 de setembro de 1958.

Por fim, nesse ano de 1958 foi elaborado o Código de Edificações de São José dos Campos, moldado na Lei no 5.261 do Município de São Paulo. Em 1959, foi preparada pelo escritório técnico local e aprovada pela Câmara Municipal uma lei disciplinadora das construções no município. A partir desse momento, deu-se início à elaboração de uma legislação que visava ordenar e resguardar os espaços em razão do crescente impulso industrial, por meio de um novo zoneamento.

Esse instrumento também teve como preocupação a preservação da Zona Residencial dos possíveis efeitos negativos resultantes da proximidade com as indústrias. Foram definidos espaços para futuro desenvolvimento urbano e delimitados os locais

\footnotetext{
${ }^{42}$ São José dos Campos, Decreto Municipal n 246, de 10 de setembro de 1958.
} 
para a construção de novas indústrias. Foi proibida a instalação de indústrias que usassem processos de fabricação que oferecessem riscos de lançamentos de gases tóxicos na atmosfera ${ }^{43}$.

Foi proibido, também, o retalhamento na Zona Rural de área inferior a 5.000 $\mathrm{m}^{2}$, com o objetivo de inibir a depreciação do meio rural. Entretanto, previa-se a formação de aglomerados satélites, dotados de melhoramentos característicos da área urbanizada. Determinou-se que a prefeitura não mais aprovaria plantas de loteamentos que não possuíssem condições mínimas de benefícios, tais como rede de água e luz elétrica ${ }^{44}$. Foram estabelecidos coeficientes de aproveitamento dos lotes e fixados gabaritos de altura para as novas edificações urbanas ${ }^{45}$.

A partir dessas diretrizes, a prefeitura mostrou-se preocupada em garantir a qualidade de vida da população, passou a exigir, para aprovação de loteamentos, as seguintes condições: projeto de rede de distribuição de água potável, indicando as fontes abastecedoras e a capacidade dos mananciais; projeto da rede de iluminação pública e domiciliar, indicando o ponto de tomada, oferecendo comprovante da capacidade técnica da fornecedora para atender à rede projetada; plano das obras para instalação das redes de água e luz com previsão do prazo para a sua execução e orçamento do custo dos serviços; prova de capacidade financeira dos interessados para ocorrer as despesas com a execução dos serviços ${ }^{46}$.

Portanto, podemos dizer que foi a partir de 1958, com a formação da Comissão do Plano Diretor do Município e com as medidas da Prefeitura Municipal que a cidade obteve uma fiscalização efetiva, norteada por uma legislação específica.

\footnotetext{
${ }^{43}$ São José dos Campos, Decreto Municipal ${ }^{0}$ 250, de 31 de outubro de 1958.

${ }^{44}$ São José dos Campos. Lei Municipal $\mathrm{n}^{\circ}$ 657, de 09 de fevereiro de 1960.

${ }^{45}$ São José dos Campos. Lei Municipal n ${ }^{\circ} 664$, de 18 de fevereiro de 1960.

${ }^{46}$ São José dos Campos. Decreto Municipal no 332 , de 27 de abril de 1960.
} 
De acordo com Santos,

(...) São José dos Campos foi uma das primeiras cidades do interior paulista a possuir um Plano Diretor moderno, sintonizado teórica e tecnicamente com os conhecimentos vigentes na década de 50. (1996, p.27)

Em 1960, enquanto o Plano Preliminar estava sendo elaborado, 30\% da área urbana já estava efetivamente ocupada com loteamentos intercalados com indústrias. Apesar de as áreas próximas à Zona Central ainda não apresentarem ocupação, alguns loteamentos já ultrapassavam a Via Dutra. Como já dito, um dos objetivos principais do Plano Diretor foi o de ordenar o uso do solo urbano e limitar as áreas passíveis de serem loteadas.

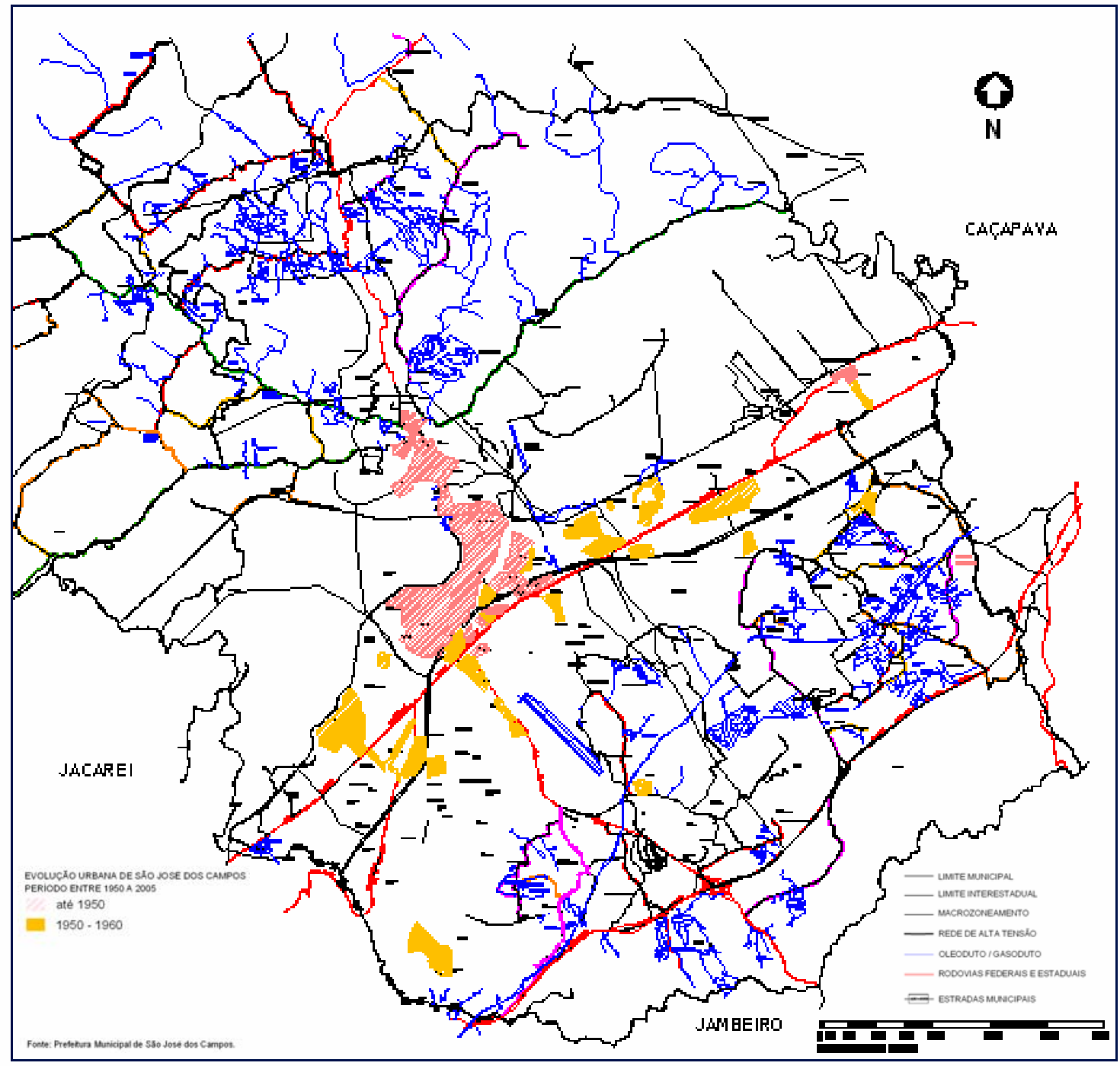

Figura 2.18 - Mapa evolução urbana no período entre 1950 a 1960 Fonte: PMSJC, 2006. 
De acordo com o resumo de trabalhos do Plano Preliminar (1964), primeiramente foram desenvolvidos estudos para elaboração de diretrizes quanto a questão do planejamento regional e apresentou, como maior dificuldade de gestão, o fato de não existir, no Estado de São Paulo, um sistema de planejamento de suas diversas regiões.

O Plano Preliminar também teve, como uma de suas diretrizes, a proposta de implantação de zoneamento de massas. Essa diretriz tratava-se de uma etapa inicial de um estudo maior e mais detalhado para a elaboração futura de um zoneamento específico para cada bairro do município. As diretrizes contidas nesse plano serão comentadas e devidamente analisadas no item 3.3 sobre o Plano CEPEU - USP.

Em 1961 foi entregue o Plano Preliminar para a Zona Urbana da sede de São José dos Campos e, após sua conclusão, foram elaborados vários Planos Setoriais, no período de 1961- 1964. Dentre eles destacam-se os seguintes trabalhos, contidos em dois volumes, denominados "Estudos e Planos Setoriais":

a) Proposta de um zoneamento industrial;

b) Plano urbanístico para a área central;

c) Plano geral de trânsito;

d) Estudos para a erradicação da favela da linha velha ${ }^{47}$

e) Programa administrativo.

Verificamos que a legislação, a partir da década de 60, através do Plano Diretor, apresentou uma legislação urbanística que visava um crescimento urbano mais harmônico; já o início da década de 60 pareceu-nos, sobretudo, um período de ampliação e consolidação da urbanização e de uma transformação qualitativa do urbano por meio da legislação elaborada nesse período.

\footnotetext{
${ }^{47}$ Segundo o Plano Preliminar de 1961, este programa desfavelamento nasceu espontaneamente da própria comunidade, cujas manifestações se deram através de reuniões, de artigos em jornais e de um ciclo de palestras sobre favelas.
} 
Em 1961, foi criado o Instituto Nacional de Pesquisas Espaciais - INPE. A instalação de um órgão federal responsável pela pesquisa e política espacial consolidou o caminho iniciado pelo CTA em busca do domínio no setor tecnológico. A partir da implantação do INPE é que se dá o início da implantação das fábricas pioneiras do setor bélico, aeronáutico e de telecomunicações em São José dos Campos.

É importante ressaltar que os pólos tecnológicos não se criam por projeto ou decreto. Eles surgem a partir de pré-condições existentes em determinado local e incluem a presença de, pelo menos, uma universidade ou instituto de pesquisas que funciona como âncora desse pólo, como é o caso de São José dos Campos e Campinas.

No ano de 1962, assumiu como Prefeito José Marcondes Pereira e identificamos algumas intervenções urbanísticas, tais como: a inclusão de loteamentos localizados na periferia do núcleo central na Zona Urbana do município ${ }^{48}$, a inclusão de avenidas e quadras na Zona Residencial ${ }^{49}$ e uma nova intervenção na delimitação da Zona Comercial ${ }^{50}$.

No mesmo ano, a pedido do Prefeito José Marcondes Pereira, o CEPEU organizou uma proposta de Programa Administrativo que era integrado no espírito das propostas do Plano Preliminar (1961). Esse programa constituiu-se no primeiro plano executivo realizado pelo CEPEU. Dentre as onze diretrizes apresentadas, destacamos que havia uma diretriz que se ocupava do problema da habitação popular como uma obrigação do poder municipal.

Em 1964, o Plano Diretor elaborado pelo CEPEU - USP foi entregue e, no Brasil, deu-se início ao regime militar. O regime militar e a ação do poder público foram marcadas fortemente nas cidades brasileiras e, em São José dos Campos, pelo fato de ser considerada uma base de segurança nacional essa ação foi ainda acentuada.

\footnotetext{
${ }^{48}$ Leis Municipais 1012/63 e 1121/63.

${ }^{49}$ Leis Municipais 1238/65 e 1288/66.

${ }^{50}$ Lei Municipal 1291/66.
} 
A crença de que o desenvolvimento e o crescimento a qualquer custo seriam sempre positivos e que a centralização de poderes no Estado, para intervir sobre a cidade, traria as soluções adequadas para resolver os problemas, caracterizou o modelo central-desenvolvimentista (BONDUKI,1996, p.261 - 267).

No Brasil daquele período, o processo de urbanização das cidades se intensificou em função do crescimento econômico e o governo buscou, por meio dos Planos Diretores, equacionar em longo prazo os problemas das cidades sem se preocupar em construir propostas num processo de debate com a sociedade.

No período militar, podemos dizer que todo o planejamento não foi autoritário; houve sim, um esforço para a constituição de um processo de urbanização mais sólido, com objetivos específicos de reequilibrar o Brasil através da centralização de cidades de porte médio, mas que, por parte de seus formuladores, houve um esforço de reflexão sobre o processo de urbanização brasileira, para a época, muito importante em termos de conteúdo e profundidade.

Em 1964, foram criados o Serviço Federal de Habitação e Urbanismo (SERFHAU), regulamentado em $1967^{51}$, e o Fundo de Financiamento de Planos de Desenvolvimento Local Integrado, no Banco Nacional da Habitação (BNH), com a finalidade de financiar os planos de estudos de desenvolvimento integrado, mas a liberação de recursos ficava condicionada à criação, pelas regiões e municipalidades, de órgãos permanentes de planejamento e desenvolvimento local.

Ao mesmo tempo em que se condicionou a liberação de recursos a uma estrutura de planejamento, essa pode contratar a elaboração dos planos e estudos ${ }^{52}$. Com essa concessão de verbas para o planejamento e para a abertura da contratação externa de planos, os órgãos de planejamento se multiplicaram, os planos e as empresas de consultoria passaram a assumir a maioria dos planos elaborados nos anos de 1960 e

\footnotetext{
${ }^{51}$ Lei Federal 4.380 de 21.8.1964 e Decreto Federal 59.917 de 30.12.1966.

${ }^{52}$ Decreto Federal 59.917 de 30.12.1966, artigos 23 e 27.
} 
1970, no país. Um dos objetivos dessa política baseava-se em estabelecer critérios de âmbito nacional para a execução dos programas habitacionais de interesse social.

Segundo Santos (1989), o SERFHAU esgotou-se precocemente na elaboração ou no financiamento a particulares de Planos Preliminares de Desenvolvimento Local Integrado, com os quais as prefeituras se capacitavam aos financiamentos governamentais para a construção de conjuntos habitacionais.

Concluindo, os avanços registrados no que se refere às políticas urbanas estatais, no início do regime militar, são aprofundados nos governos seguintes no sentido da conformação de uma política nacional de desenvolvimento urbano.

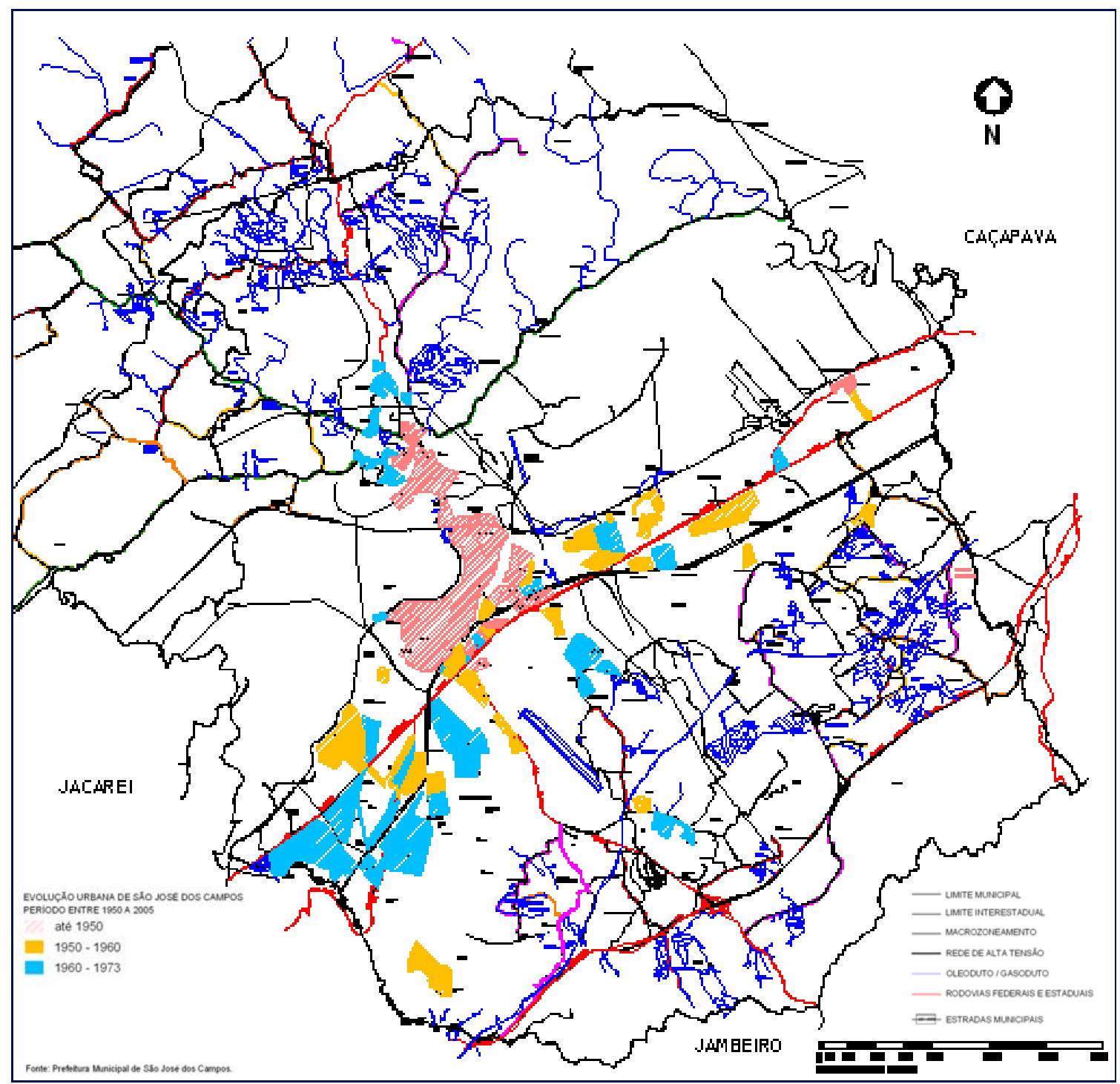

Figura 2.19 - Mapa evolução urbana - período entre 1960 a 1973 Fonte: PMSJC, 2006. 


\subsubsection{Quarto Período: 1970 até 2000}

No Brasil, a partir da década de 70, o processo de urbanização das cidades se intensifica em função do crescimento econômico e o governo buscou, por meio dos Planos Diretores, equacionar, a longo prazo, os problemas que as cidades vinham enfrentando em decorrência desse processo acelerado.

No Vale do Paraíba, no início da década de 70, os prefeitos dos municípios começaram a discutir a idéia de criar um consórcio que promovesse o desenvolvimento dessa região. Dentro desse contexto, foi elaborado o segundo Plano Diretor de Desenvolvimento Integrado de São José dos Campos.

O PDDI de 1971 teve início em 1969 por meio da contratação da empresa Serete S/A Engenharia pela prefeitura municipal, fazendo parte deste trabalho, como subcontratada, a SD Consultoria de Planejamento Ltda. e Jorge Wilhein Arquitetos Associados como responsável pelos aspectos urbanísticos.

Este contrato deu-se na gestão do prefeito Elmano Ferreira Veloso (1966 a 1970), tendo sido entregue, em sua gestão, o Plano Preliminar. Coube ao seu sucessor, Brigadeiro Sérgio Sobral de Oliveira, que assumiu a prefeitura em 04 de fevereiro de 1970, discutir as minutas apresentadas pelos técnicos, aprovar e receber o plano em sua versão final.

Uma das estratégias adotadas no PDDI foi a de estimular a ocupação e o adensamento de grandes vazios urbanos existentes no município e, por meio dessa diretriz, conseguir uma certa linearidade na ocupação do solo.

A primeira medida adotada para que fosse conseguida essa linearidade foi a elaboração de uma lei de uso e ocupação do solo que incentivasse a construção de edifícios para habitações coletivas e comerciais, conjuntos habitacionais verticais e horizontais. 
O adensamento de um desses vazios urbanos, localizado na Região Leste, nos bairros Vila Industrial e Jardim Ismênia, citados aqui como exemplo, tornaram-se realidade com a implantação de conjuntos habitacionais Tatetuba, Honda e Planalto.(fig. 2.20)

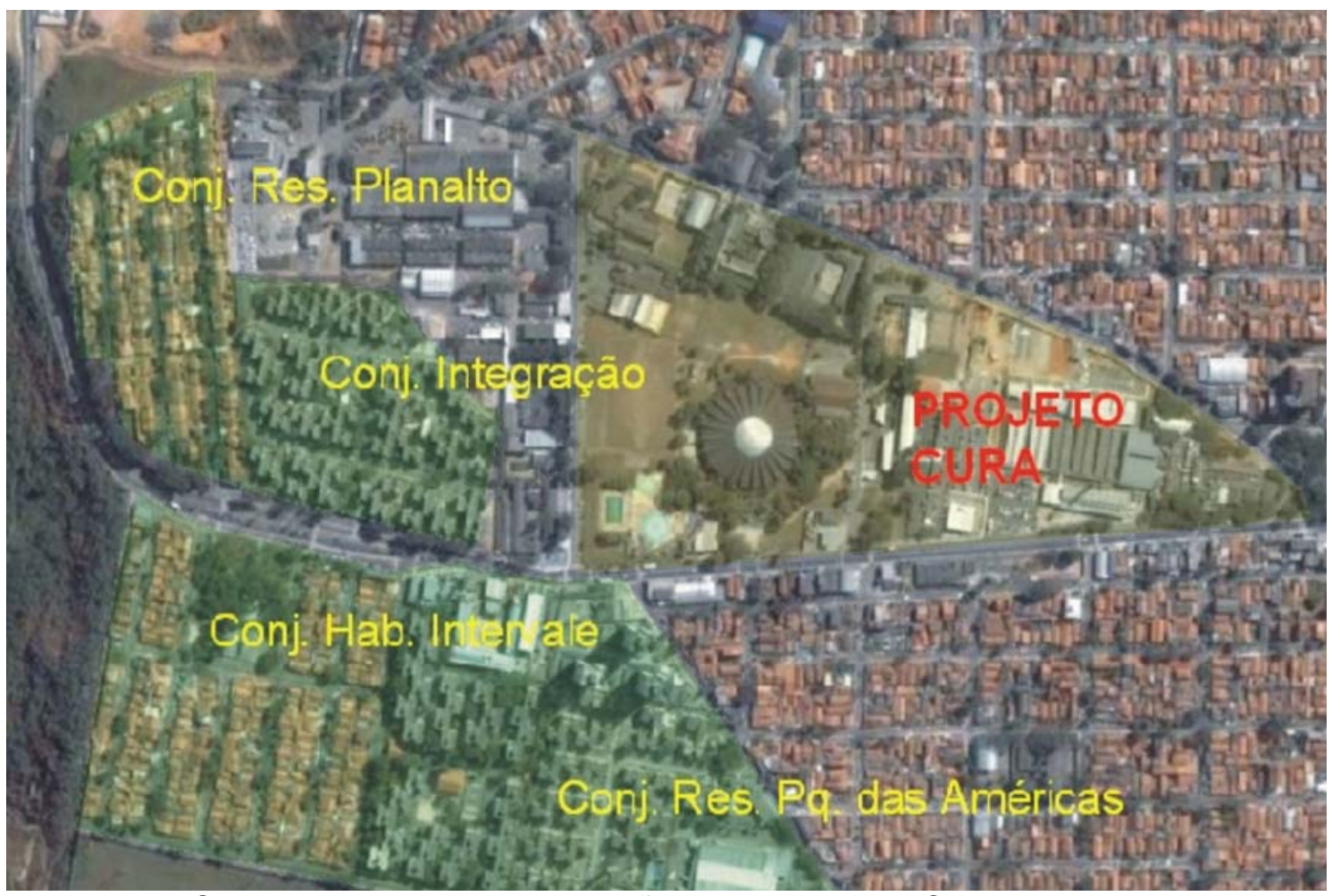

Figura 2.20 - Conjuntos habitacionais na Região Leste e o Projeto CURA. Fonte: Google Earth, 2006.

Aliado a essa medida, como fato positivo, nesses loteamentos foi implantado o projeto CURA - Comunidade Urbana para Recuperação Acelerada, financiado pelo $\mathrm{BNH}$, promovendo uma radical transformação na região em termos de infra-estrutura básica e de equipamentos para educação, saúde e lazer. (fig. 2.21) 


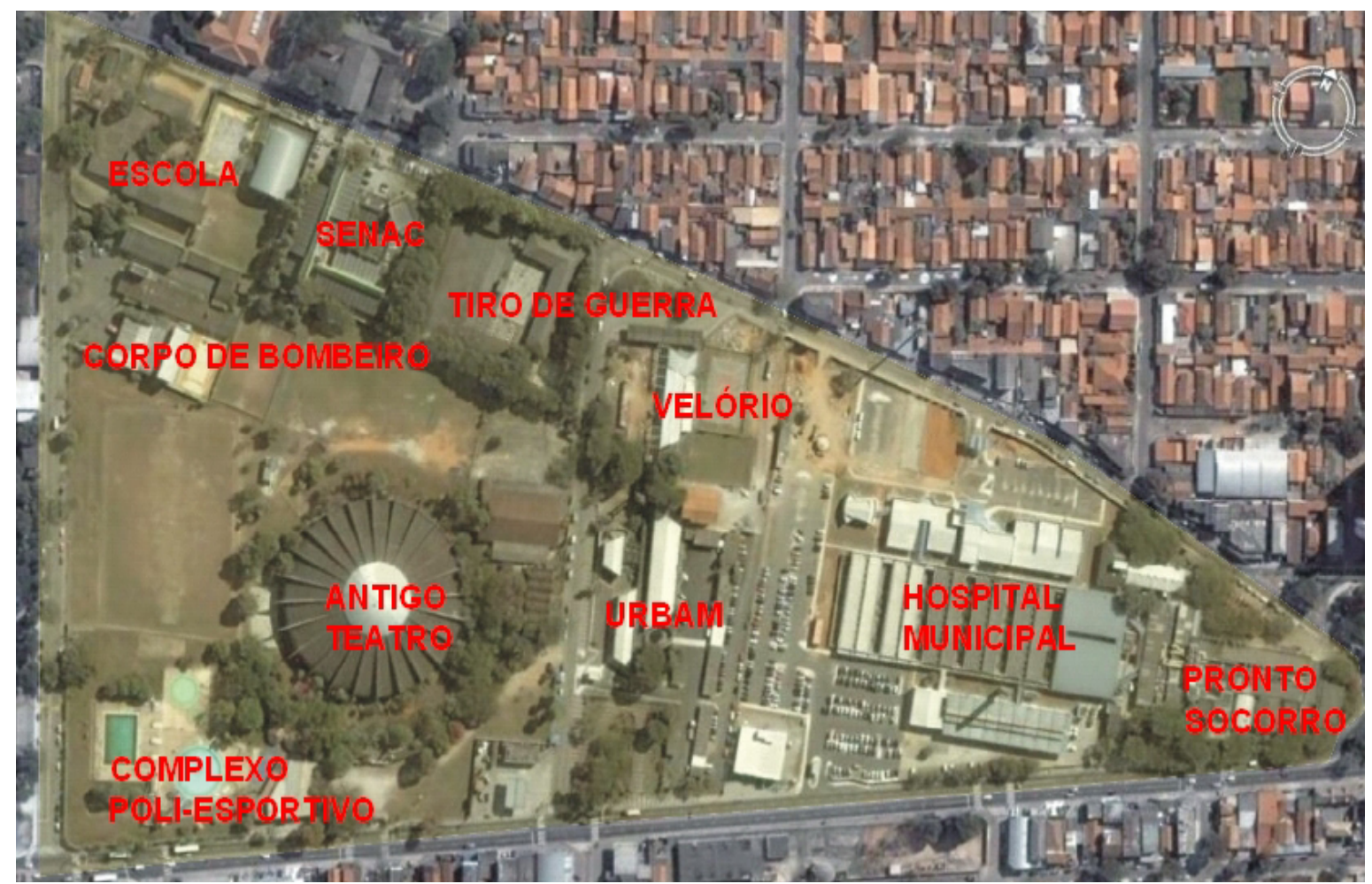

Figura 2.21 - Quadra destinada aos equipamentos comunitários: Teatro, Tiro de Guerra, Hospital, Pronto Socorro, Velório Municipal, Urbam S/A (Urbanizadora Municipal) e complexo poliesportivo Fonte: Google Earth, 2006.

O PDDI -1971 propôs também, em suas diretrizes, uma nova legislação de Parcelamento do Solo, aprovada em 15 de setembro de 1970 por meio da Lei Municipal $n^{\circ}$ 1576/70, que estabeleceu os requisitos para a implantação de novos loteamentos, contendo diretrizes urbanísticas, obras de infra-estrutura, normas para aprovação até o sistema de garantia para execução das obras por parte do loteador.

No início dos anos 70, as áreas próximas à Zona Central são efetivamente ocupadas iniciando-se o processo de verticalização, tanto da área central como das áreas próximas, o que permitiu um maior adensamento. A Região Sul foi a que mais sofreu impacto desse crescimento, por causa da instalação de indústrias, da maior ocupação de loteamentos já existentes e da implantação de conjuntos habitacionais. Atualmente, essa região é a que possui a maior população do município. (Fig. 2.22) 


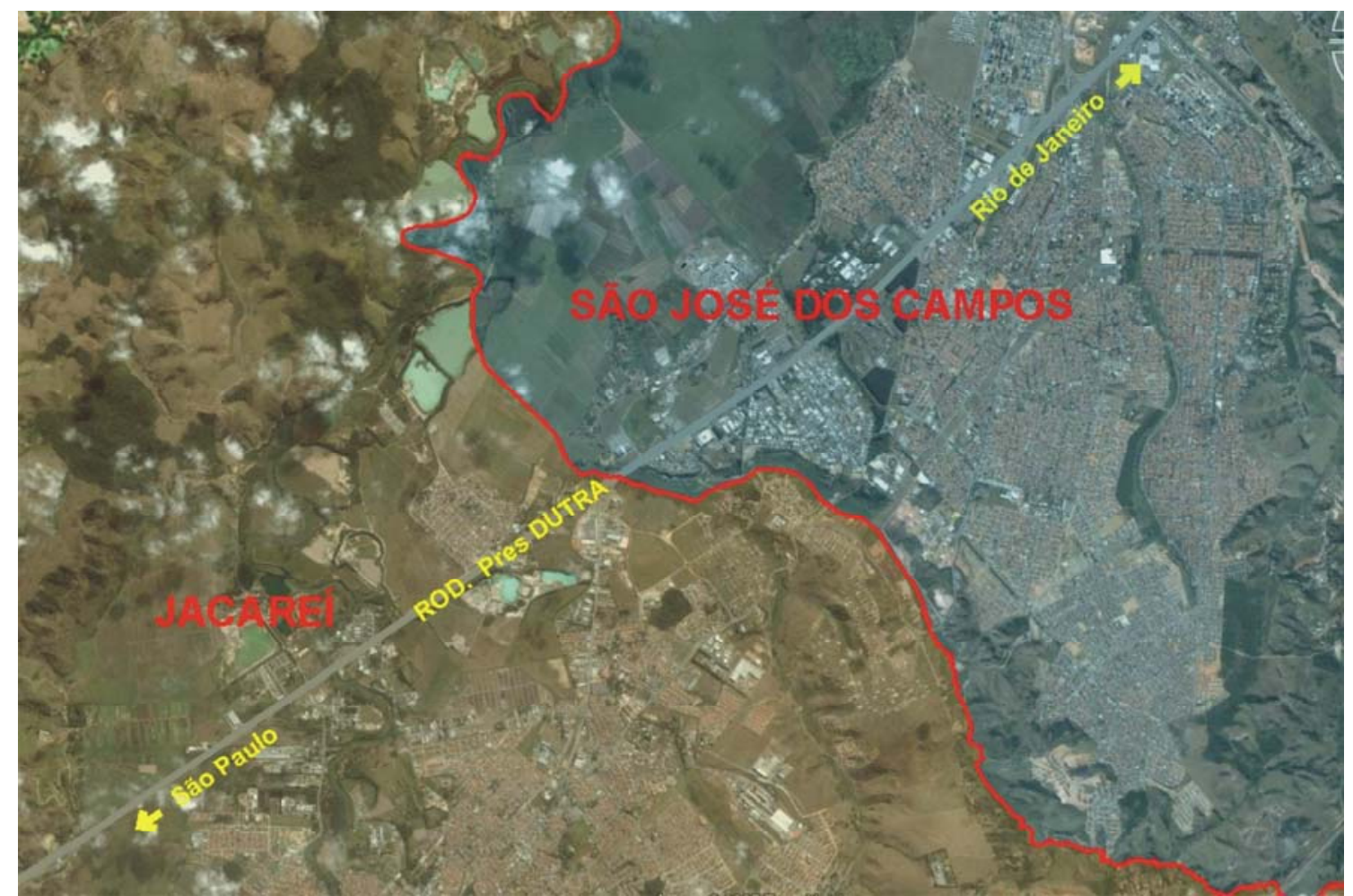

Figura 2.22 - Zona Sul e limite com Jacareí Fonte: Google Earth, 2006.

A política adotada no PDDI-1971 foi a de não incentivar a expansão horizontal, à exceção dos vazios urbanos das áreas urbanizadas e também exigia todas as obras de infra-estrutura, à exceção da pavimentação.

Em decorrência dos estudos advindos do Plano de Desenvolvimento Integrado, vários instrumentos legais foram promulgados quase que simultaneamente:

1) Organização administrativa da Prefeitura. Lei Municipal no 1537 de 03 de março de 1970;

2) Código Administrativo. Lei Municipal nº 1566 de 01 de setembro de 1970;

3) Lei de loteamentos urbanos. Lei Municipal $n^{\circ} 1576$ de 25 de setembro de 1970;

4) Sanções do código de edificações. Lei Municipal no 1575 de 25 de setembro de 1970;

5) Código Tributário. Lei Municipal nº 1577 de 30 de setembro de 1970; 
6) Código de Edificações. Lei Municipal no 1578 de 07 de outubro de 1970;

7) Plano Trienal de Investimentos.

Em 17 de junho de 1971, por meio do ofício 017/71/DJ, o Prefeito Sérgio Sobral de Oliveira, encaminha à Câmara Municipal o projeto de Lei 1606/71, que dispunha sobre o uso e ocupação do solo do município. Após dois meses, o projeto encaminhado entra em votação na sessão da Câmara Municipal de 17 de agosto de 1971.

A Lei Municipal n 1606/71, quando de sua promulgação, apresentava-se relativamente simples se comparada às atuais leis de zoneamento, contando com apenas 25 artigos. Essa lei propunha que o município fosse dividido em Zona Urbana, Zona de Expansão Urbana e Zona Rural. Os perímetros dessas zonas seriam fixados por lei e as zonas de uso, inseridas na zona urbana e de expansão urbana, teriam seus perímetros delimitados por meio de ato do executivo, ou seja, por decreto, o que dispensava consulta ao poder legislativo, tanto na sua formulação como numa eventual alteração desses.

O município adentrou a década de 70 com uma estrutura espacial de caráter urbano-industrial em fase adiantada de consolidação e, por meio do Consórcio do Desenvolvimento Integrado do Vale do Paraíba e Litoral Norte (CODIVAP), foi elaborado um diagnóstico do Vale do Paraíba, detalhado no item 3.2.

Nesse período, todo o planejamento foi pensado e executado para o desenvolvimento econômico, para a industrialização e para a modernização do aglomerado do Vale do Paraíba e, principalmente, para São José dos Campos que foi o foco das atenções e de suas diretrizes.

Enquanto o CODIVAP elaborava seu diagnóstico e suas diretrizes para o Vale do Paraíba estavam sendo implantadas e regulamentadas diversas leis de ordenamento do município seguindo os conceitos estabelecidos no PDDI de 1971, a seguir relacionadas: 
1) Lei Municipal $n^{\circ} 1576$ de 15 de setembro de 1970 - Dispõe sobre Loteamentos Urbanos;

2) Lei Municipal $n^{\circ} 1575$ de 25 de setembro de 1970 - Dispõe sobre multas e sanções para todas as obras e edificações que não obedecerem às prescrições do Código de Edificações, da Lei de Loteamentos e da legislação sobre uso do solo e zoneamento;

3) Lei Municipal $n^{\circ} 1578$ de 7 de outubro de 1970 - Dispõe sobre o Código de Edificações do Município;

4) Lei Municipal $n^{\circ} 1606$ e 1617, respectivamente, de 13 de setembro e 21 de outubro de 1971 - Dispõe sobre o Zoneamento e o Uso do Solo;

5) Decreto Municipal $n^{\circ} 1412$ de 27 de setembro de 1971 - Dispõe sobre a descrição dos perímetros das Zonas de Uso;

6) Lei Municipal $n^{\circ} 1623$, de 30 de novembro de 1971 - Lei do Plano Diretor.

É importante ressaltarmos que, além destas leis e decretos que fazem parte do PDDI, foram aprovadas as seguintes leis:

1) Código de Posturas Municipais. Lei Municipal no 1566 de 01.09.1970;

2) Código Tributário Municipal. Lei Municipal no 1577 de 30.09.1970;

3) Plano Trienal de Investimentos 1972-1974. Lei Municipal no 1626 de 30.11.1971.

Todas são citadas na Lei do Plano Diretor como diretrizes a serem seguidas e que serão melhor explicitadas no Capítulo 3, específico, sobre a legislação urbanística de São José dos Campos.

Com a aprovação dessas leis e decreto esperava-se que o processo de urbanização que, naquele período, continuava a apresentar um significativo espraiamento e adensamento, com transbordamento por sobre as infra-estruturas preexistentes, tais como: as rodovias, a ferrovia e o Rio Paraíba do Sul e os pequenos fundos de vale fosse diminuído, no entanto, isso não ocorreu. 
Verificou-se que a Região Central começava a se especializar em atividades de comércio e serviços e o processo de esvaziamento do uso e ocupação residencial começava a se deslocar para áreas em verticalização e para outros platôs mais distantes do Centro. Tais ocupações e transposições são induzidas pelas infra-estruturas de acesso e pela proximidade dos novos setores de produção e pelos custos imobiliários das áreas centrais e do entorno imediato.

Segundo Santos (1993), a distribuição espacial da urbanização, nesse período, acabou por se configurar de dois modos que, contudo, parecem concomitantes. São eles: a) contíguos que acompanham as áreas industriais de porte ao longo da Rodovia Presidente Dutra e b) num eixo Norte-Sul, de forma estrangulada ao Norte do município decorrentes da existência da planície de fundo de vale em aluvião e terrenos com baixa resistência.

No dia 08 de julho de 1975 assume, como prefeito nomeado, Ednardo de Paula Santos que apresenta um programa de obras de acordo com uma visão geral e integrada, mas não fazendo nenhuma referência ao PDDI-1971.

Nesse período, ocorre a elaboração de vários projetos setoriais que refletiram o processo de planejamento que, em São José dos Campos, vinha sendo adotado. Dentre eles destacamos: o Plano Diretor de Creches, o Plano Diretor de Equipamentos de Saúde, o Projeto Geométrico do Anel Viário, o Plano de Cadastramento de Drenagem de Águas Pluviais e o Programa de Transporte Urbano.

Enquanto São José dos Campos vivia o período em que o Plano Diretor de 1971 não continha diretrizes articuladas com a esfera estadual, começava a ser elaborado o Plano Regional do Macro-Eixo Paulista que tinha como uma de suas maiores diretrizes a preocupação com as demandas sociais. O plano municipal se preocupava em atrair o capital industrial.

O Plano do Macro-Eixo denunciou as conseqüências do processo de planejamento que vinha sendo utilizado naquele período como um processo que, a 
serviço do capital, realocou estruturas e serviços sem, contudo, se voltar às demandas sociais. A distribuição de serviços foi apresentada pelo plano como um processo de distribuição de renda.

São José dos Campos estava na contramão do pensamento urbanístico colocado no plano Macro-Eixo. No entanto, o Plano Diretor de 1971 tinha como uma de suas diretrizes a relocação dos moradores da favela da "linha velha" para um conjunto habitacional distante cerca de $10 \mathrm{~km}$ do Centro, para que, em seu lugar, fossem construídos parte do Anel Viário e o atual Paço Municipal.

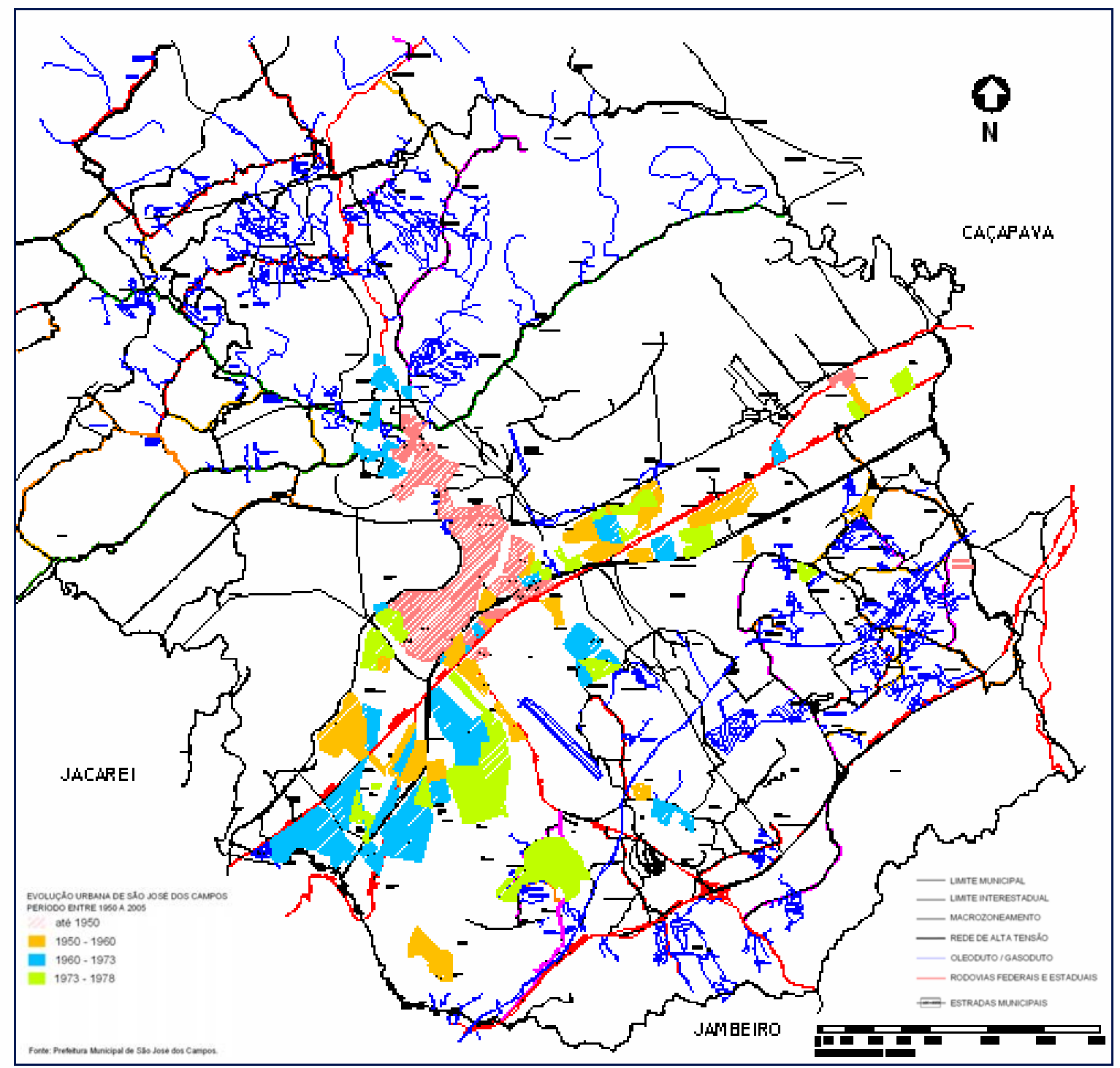

Figura 2.23 - Mapa evolução urbana - período entre 1973-1978 Fonte: PMSJC, 2006. 
No período entre 1970 e 1978, o Estado interferiu na autonomia política de São José dos Campos, amparado na legislação estadual que elevara, em 1935, o município à condição de Estância Climática e Hidromineral e, novamente, os prefeitos passaram a ser nomeados pelo Estado.

Somente em 1979, assumiu por voto popular, o Prefeito Joaquim Bevilacqua e, no seu governo, foi elaborado um grande projeto habitacional para as famílias de baixa renda, na Região Sul do município, conhecido como Campo dos Alemães, em área de 3,5 milhões de metros quadrados, com previsão para a implantação de 8.000 unidades habitacionais.

Nesse mesmo ano, iniciou-se a construção do Programa Habitacional, na Região Sul, implantado pela Empresa Municipal de Habitação (EMHA), destinado à população de baixa renda, com 847 unidades habitacionais.

Na década de 80, foi aprovada a Lei de Parcelamento e de Zoneamento (Lei Municipal $n^{\circ} 2263 / 80$ ), elaborada nos moldes da Lei de Uso e Ocupação do Solo de São Paulo e Campinas. Essa lei teve como uma de suas diretrizes a ampliação do perímetro de expansão urbana do município e abriu a possibilidade de expansão horizontal da cidade por meio de novos loteamentos. Essa política foi totalmente contrária às diretrizes propostas no Plano Diretor de 1971, o que confirmava que os dirigentes não se preocupavam em seguir as diretrizes que constituíam esse plano.

Em 1981 foi criada a Secretaria de Planejamento e Informática, sendo que o departamento de planejamento continuou a exercer seu papel de coordenação e acompanhamento dos Planos e Programas. Destacamos nesse período, a formulação de uma proposta elaborada por essa secretaria para a primeira lei sobre o Patrimônio Histórico e Ambiental do Município.

A administração de Robson Marinho (1983-1986) passou a tomar medidas para conter a situação irregular dos loteamentos, as quais foram feitas por meio de medidas judiciais contra os empreendedores. Essa atitude do Executivo visava o 
cumprimento da execução das obras de infra-estrutura prevista e o papel da Secretaria de Planejamento se restringia, exclusivamente, na reformulação da legislação de parcelamento e zoneamento.

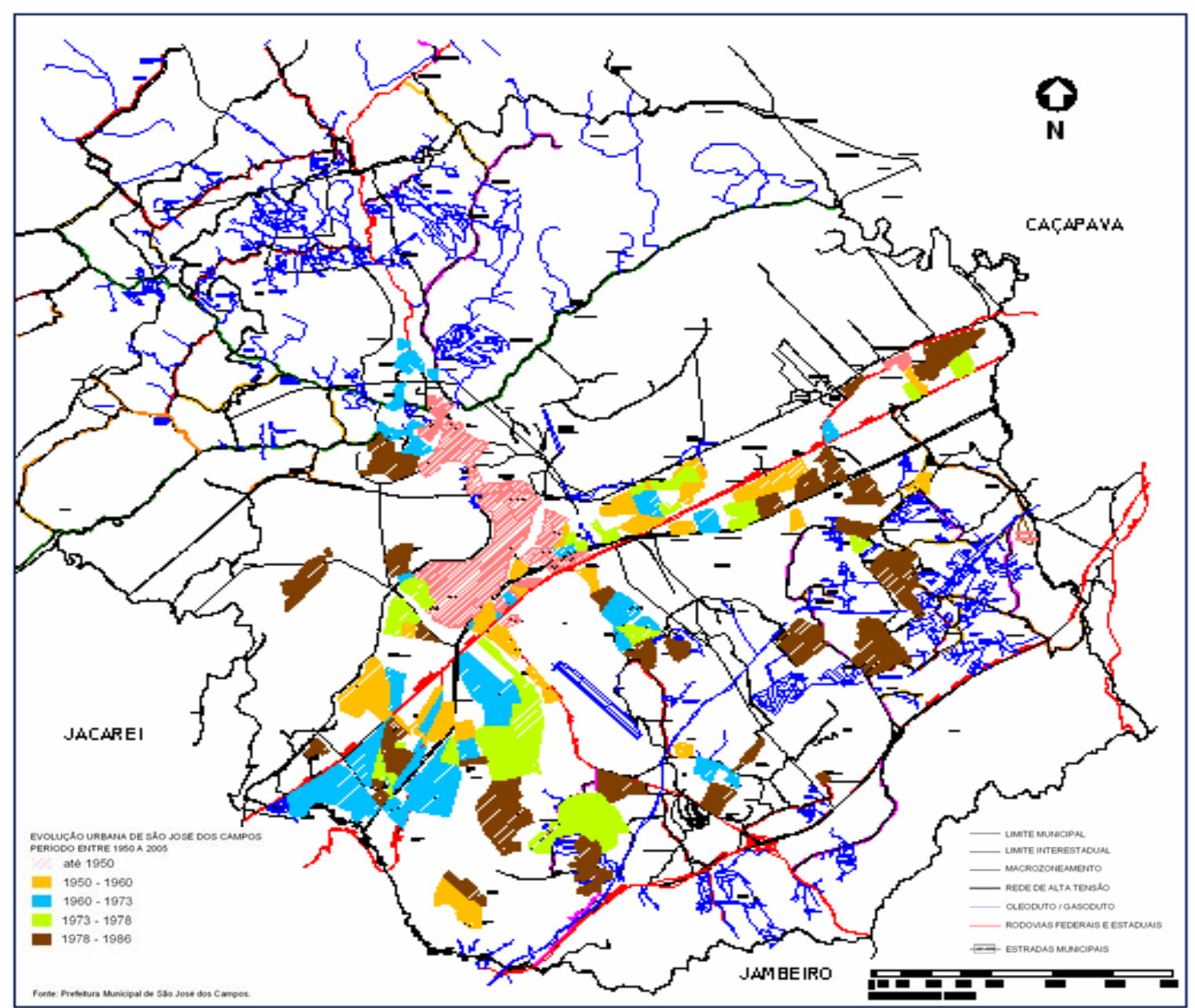

Figura 2.24 - Mapa evolução urbana - período entre 1978 a 1986 Fonte: PMSJC, 2006.

Sobre a situação irregular dos loteamentos, em 1984, de acordo com o estudo elaborado pela Secretaria de Planejamento sobre a expansão física do município de São José dos Campos, foram identificados 117 núcleos de chácaras de recreio.

Inicialmente caracterizados como Chácaras de Recreio e, posteriormente, subdivididos em parcelas menores, com características urbanas e com intensiva ocupação pela população de baixa renda. Essas ocupações concentraram-se principalmente nas Regiões Norte e Leste do Município. Sem que o poder público conseguisse conter ou reverter esse processo e, de acordo com esse estudo, a ocupação 
da Zona Rural por loteamentos irregulares iniciou-se, como já dito, no período entre 1960 a 1970 quando o processo de urbanização foi mais intenso.

Com o objetivo de englobar esses inúmeros loteamentos irregulares que se encontravam dispersos na malha urbana, em 1985, o perímetro urbano foi retraído. Simultaneamente, buscou-se incentivar a ocupação dos vazios existentes entre esses loteamentos e a área urbanizada para que a malha urbana se tornasse mais homogênea.

No entanto, o que foi constatado é que, apesar dessa retração, nesse período, o processo de ocupação da Zona Rural foi intensificado pela própria rigidez da Lei de Parcelamento associada à falta de uma política habitacional e à ineficiência da fiscalização do município.

Em 10 de maio de 1986 assume o Prefeito Hélio Augusto de Souza e, diante seu inesperado falecimento em 31 de outubro daquele mesmo ano, assume o Prefeito Antonio José Mendes Faria. Começaram os estudos de revisão geral das Leis de Parcelamento e Zoneamento, por causa dos graves problemas de ocupação e a rigidez da lei de zoneamento.

Em $1^{\circ}$ de janeiro de 1989, assume novamente o Prefeito Joaquim Bevilacqua que encaminha à Câmara Municipal o projeto de lei referente à legislação de Parcelamento e Zoneamento. No dia 25 de janeiro de 1990 foi aprovada a nova legislação de Parcelamento e de uso e ocupação do solo. (Lei Municipal $n^{\circ}$ 3721/90).

Essa lei teve como objetivo principal incentivar o parcelamento regular e, para tanto, foram criados três tipos de loteamentos: A, B e C, com exigências diferenciadas de obras de infra-estrutura. Por meio dessas diretrizes, o poder público visava estimular a iniciativa privada a produzir lotes para todas as classes sociais.

$\mathrm{Na}$ esfera estadual, iniciaram-se os estudos para elaboração do Macrozoneamento da região do Vale do Paraíba e Litoral Norte do Estado de São Paulo (MAVALE), sob a coordenação da Secretaria de Planejamento Estadual em parceria com o Instituto de Pesquisas Espaciais (INPE) e parceria com o CODIVAP. 
Esse estudo foi elaborado para atender ao processo acelerado de industrialização que vinha transformando o Vale do Paraíba e da possibilidade do "risco ambiental" que poderia acompanhar esse processo. O Governo Federal, o CODIVAP e o INPE mostraram a necessidade de ser elaborado um macrozoneamento da região. $\mathrm{O}$ planejamento e a questão ambiental ganharam novas perspectivas no cenário nacional e, como substrato, foi elaborada uma noção de desenvolvimento sustentável.

Enquanto o Estado estava preocupado com o meio ambiente e o desenvolvimento sustentável, em São José dos Campos a ocupação irregular e a clandestinidade surgiam nas diversas regiões do seu território.

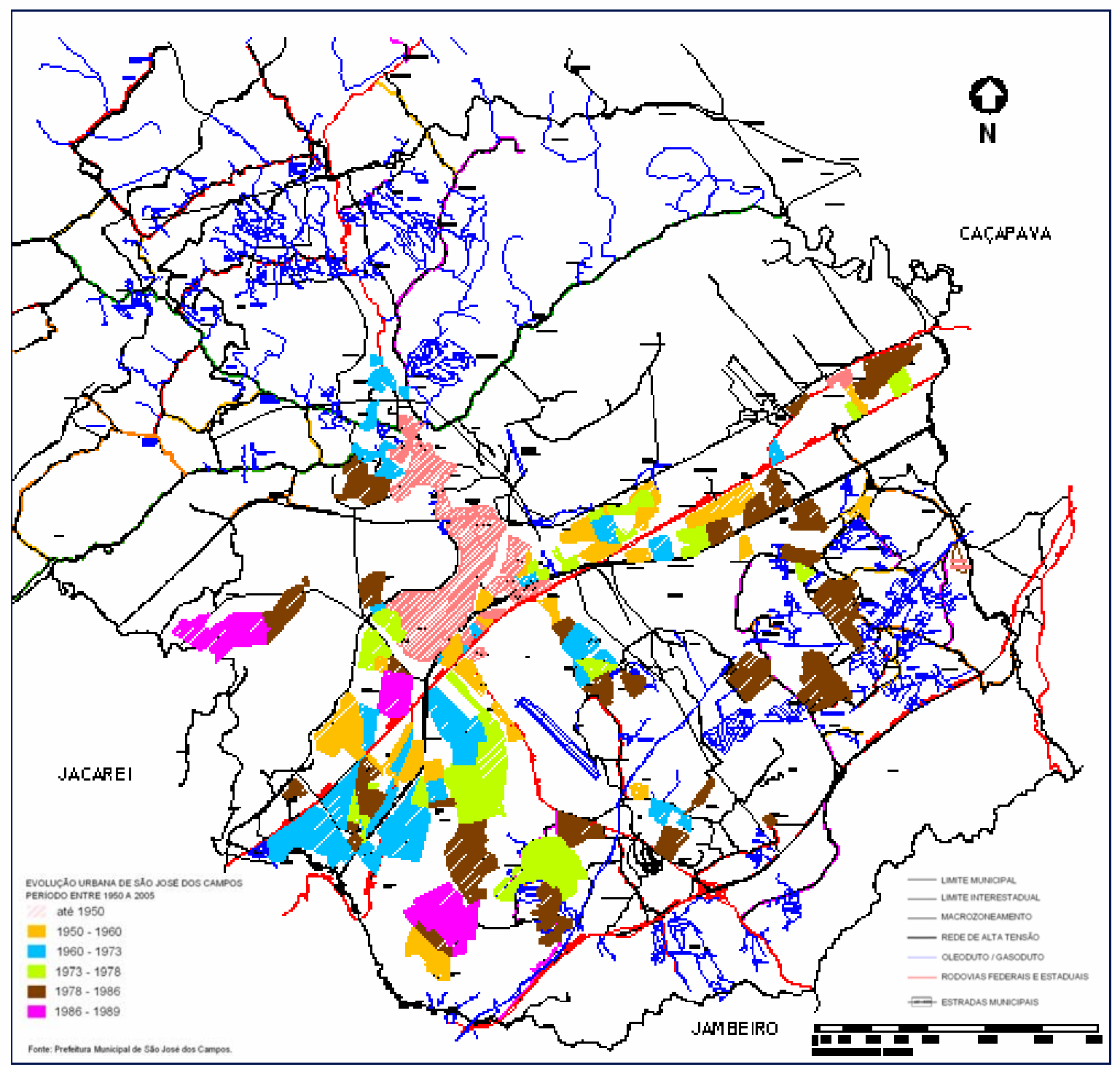

Figura 2.25 - Mapa evolução urbana - período entre 1986 a 1989 Fonte: PMSJC, 2006. 
No início dos anos de 1990, assume o Prefeito Pedro Yves (1990-1992). Em sua gestão foi retomado o Programa Habitacional e foram construídas 4.000 unidades financiadas pelos governos federal e estadual, por meio do Plano de Ação Imediata de Habitação Popular (PAIH) e da Companhia de Desenvolvimento Habitacional e Urbano (CDHU).

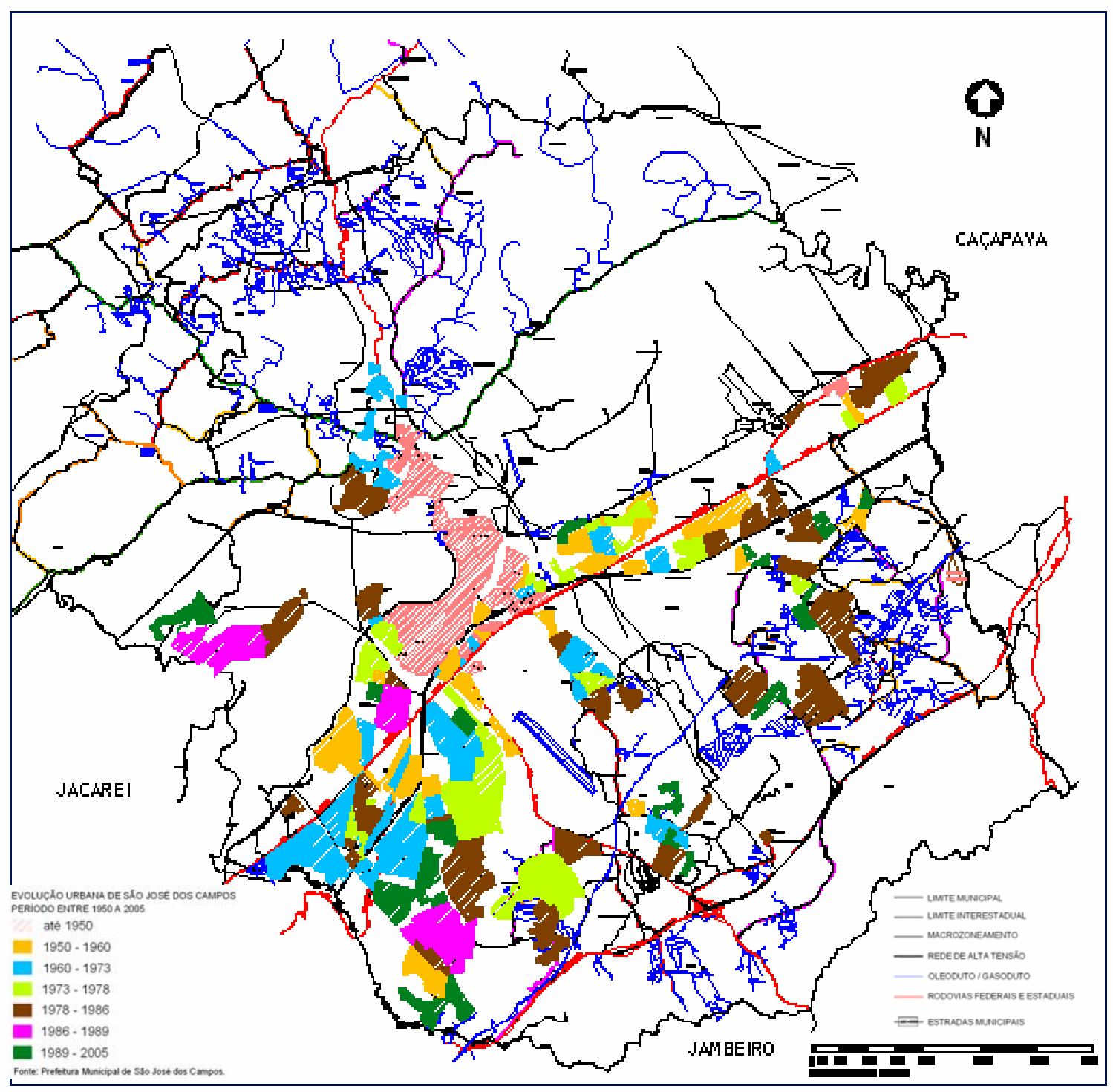

Figura 2.26 - Mapa evolução urbana - período entre 1989 a 2005.

Fonte: PMSJC, 2006. 
Em 1992, foi concluído o Macrozoneamento do Vale do Paraíba e Litoral Norte. Esse plano marcou a retomada do planejamento regional e da questão física e ambiental estabelecida nas macrozonas urbanas e nas áreas que deveriam ser protegidas ambientalmente.

Neste período foram planejadas as ações para a elaboração do PDDI de 1995 que passou por três fases. A primeira pautada no levantamento de dados físicos e socioeconômicos do município; a segunda, entre 1991/1992, se deu com a contratação de Assessoria da Universidade Estadual Paulista - UNESP / Rio Claro que, com a Secretaria de Planejamento e as equipes técnicas das Secretarias e Fundações da Administração Municipal, elaborou o estudo de cada área de atuação e passou a promover intensas discussões, visando definir os objetivos e diretrizes gerais do PDDI e os respectivos programas e projetos necessários para o desenvolvimento do município.

No início de 1993, teve início a terceira e última fase do PDDI de 1995, que resultou na elaboração do primeiro volume do Plano, denominado "Plano Preliminar". O PDDI foi aprovado em 09 de junho de 1995 por meio da Lei Municipal Complementar $n^{\circ}$ $121 / 95$.

Após a promulgação do PDDI em 1995, foi regulamentada a legislação de Parcelamento do solo, Zoneamento, ZEIS - Zonas Especiais de Interesse Social e o Conselho Municipal de Desenvolvimento Urbano. A seguir apresentamos a foto aérea da Região Leste onde identificamos o surgimento de inúmeros loteamentos clandestinos, assunto apresentado no Capítulo 4. 


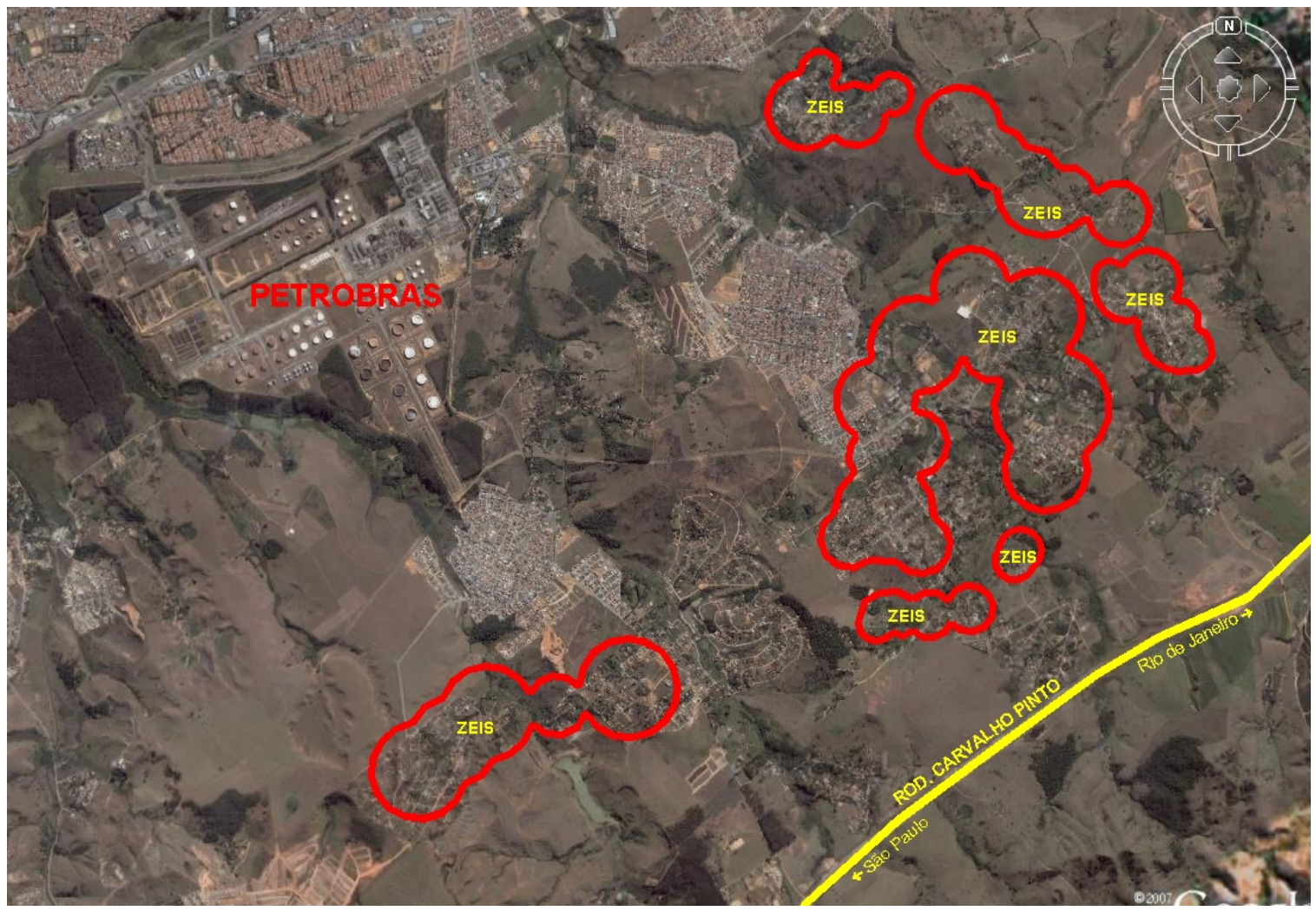

Figura 2.27 - Ocupação irregular na Região Leste do município. Fonte: Google Earth, 2006.

Após a apresentação sobre a evolução urbana de São José dos Campos que utilizou a legislação urbanística como eixo, no Capítulo 3 serão analisados, mais especificamente, a legislação urbanística e o crescimento econômico ocorrido nessa cidade. 


\section{CAPÍTULO 3 - LEGISLAÇÃO URBANÍSTICA}

Este capítulo tem por objetivo apresentar um levantamento e a sistematização da legislação urbanística, aqui entendida como os Planos Regionais, os Planos Diretores Municipais e as Leis de Zoneamento, compreendendo o período de 1950 a 2000.

O período de estudo foi eleito em função de que, a partir da década de 50 , São José dos Campos passou por um acelerado processo de industrialização e de urbanização e, no ano de 2000, foi publicado o Censo do IBGE.

Para apresentar os aspectos que incidiram na legislação do período eleito, adotamos como meta a elaboração e análise pautada nos seguintes aspectos: estudo dos fatos e das práticas do urbanismo, bem como o planejamento urbano de São José dos Campos; apresentação do processo histórico da urbanização da cidade, a partir da sistematização de seus instrumentos reguladores; indicação de procedimentos e métodos que venham a contribuir para que os novos Planos Diretores sejam implementados sem que, para isso, ocorram contradições urbanas resultantes da ausência de políticas claramente definidas.

Ressaltamos que a divisão deste Capítulo foi feita por escala e não por data.

\section{1 Âmbito Regional}

\subsubsection{Os Primeiros Planos Regionais para o Vale do Paraíba}

Praticamente em toda a região do Vale do Paraíba, as cidades em maior ou menor grau, foram afetadas pela política econômica do período Vargas.

As intervenções do governo Vargas para a industrialização tiveram início a partir de 1933, quando foi criada a legislação trabalhista e estabelecido o monopólio do Estado sobre os recursos hidrominerais com o Código de Águas, em 1934, além da 
nacionalização das empresas estrangeiras. Setores de infra-estrutura, transporte, comunicação e energia eram pontos de estrangulamento inadiáveis para a implementação dos empreendimentos industriais no país.

Em 1934, foi elaborado o Plano Geral de Viação Nacional em que figurou a BR-116, posteriormente chamada Rodovia Presidente Dutra (1944-1951), constituindo-se como um dos principais fatores para a rápida transformação da região do Vale em área de expansão industrial a partir das áreas metropolitanas: Rio de Janeiro e São Paulo.

Como apresentado no Capítulo 1, o período marcado pelo Estado Novo, a ditadura Vargas, foi um período emergente na região do Vale do Paraíba. O marco da ação planejadora desse governo foi por meio do Decreto $n^{\circ} 9.716$, de 09 de novembro de 1938, que dispôs diretrizes para um programa de reerguimento econômico da região e teve dois enfoques principais.

Primeiramente, o plano foi direcionado para propostas de empreendimentos agropecuários e da organização econômica (indústria e comércio), através da assistência ao cooperativismo. Para sua implementação foram feitos estudos geomorfológicos da paisagem oriunda do processo de ocupação da região. Para isso, foi criada uma estrutura burocrática, o Departamento de Assistência ao Cooperativismo. Em segundo lugar, foi determinada a criação de estações experimentais e hortos florestais, a cargo do Instituto Agronômico do Estado de São Paulo, o mais importante centro de pesquisas da época, para implantar projetos agropecuários e industriais na região.

Em 1940, o Instituto Agronômico concluiu seus estudos e propôs o primeiro plano regional do Brasil chamado Aspectos do Vale do Paraíba e seu reerguimento no Governo Adhemar de Barros. Este plano orientou o governo paulista no trato da questão agropecuária propondo a ocupação das várzeas do Paraíba com hortifrutigranjeiros e pecuária leiteira em minifúndios que visavam, principalmente, o mercado da capital. $\mathrm{O}$ Plano também teve como proposta o aproveitamento do potencial hidrelétrico e da 
navegação do Paraíba, sugerindo a criação de uma hidrovia que ligaria o Paraíba ao Tietê e, posteriormente, o Tietê ao Paraná.

Ressaltamos as perspectiva e propostas a que o Plano remeteu, quer seja na agropecuária, quer na questão da hidrovia para o desenvolvimento econômico. Esse projeto teve seus fundamentos ligados, em todos os aspectos, ao planejamento regional estatal que emergiu como proposta dos estudos geográficos e econômicos daquele período. Além dos programas agropecuários, o Plano, ao tratar do potencial energético e de navegabilidade do Paraíba, já indicava a vocação industrial da região. Todo o projeto tinha como base a estatização e o controle do desenvolvimento do Vale do Paraíba nas mãos do Estado.

O plano elaborado pelo IAC - Instituto Agronômico de Campinas instituiu o Serviço de Melhoramentos do Vale do Paraíba, com sede na cidade de Taubaté, a mais tradicional da região naquela época, e tinha como unidade de referência a bacia hidrográfica do Paraíba do Sul que, além dos programas agropecuários, tratava do potencial energético e de navegabilidade do Paraíba.

De acordo com o estudo do IAC, a presença da CSN - Companhia Siderúrgica Nacional no Vale do Paraíba resolveria o problema de se construir a hidrovia, ou seja, garantiria, de acordo com os técnicos do Instituto Agronômico, mais de 1 milhão de toneladas de materiais que encontrariam, na navegação fluvial, sua via natural de escoamento.

A instalação da CSN em Volta Redonda, em 1941, e o projeto do Centro Técnico Aeroespacial - CTA em São José dos Campos, pelo governo federal, em 1946, foram inseridos na perspectiva estratégica que o Vale assumiu a partir do Estado Novo. Naquele período, o Vale se tornava o novo foco da agropecuária, estabelecido sob parâmetros técnico-científicos e político-econômicos, assumidos em busca da posição do governo brasileiro na divisão internacional do trabalho. 
O Vale do Paraíba apareceu nos estudos realizados sobre o Estado de São Paulo como berço do café. Em sua primeira fase, marcado pela escravidão e pelos barões. A outra imagem marcante do Vale do Paraíba era a criada por Monteiro Lobato: "as cidades mortas", a decadência de uma elite tradicional que não soube acompanhar o progresso que o complexo cafeeiro, conquistador das terras do Oeste Paulista proporcionou, não somente àquela região, mas para todo o Estado de São Paulo e Brasil.

Em relação a São José dos Campos, a principal medida do governo federal, relacionou-se à escolha, em 1946, para sediar o CTA - Centro Técnico de Aeronáutica, posteriormente chamado de Centro Tecnológico Aeroespacial. São José dos Campos foi escolhida devido à situação geográfica - eixo Rio - São Paulo. Esse centro foi planejado para ser um misto de núcleo de formação e produção especializada e tornou-se o embrião da indústria aeronáutica, bélica e aeroespacial brasileira, além de formar especialistas em mecânica, eletrônica e informática.

\subsubsection{Consórcio de Desenvolvimento Integrado do Vale do Paraíba e Litoral Norte}

No período entre 1961 a 1964, como resultado dos planos setoriais elaborados pelo CEPEU para São José dos Campos, foi feita uma proposta de criação de um convênio de consórcio para execução de obras e serviços, visando o desenvolvimento do Vale do Paraíba. Essa idéia se colocou sob a forma de uma solução para questões de abrangência regional que poderia incluir mais de um município ao mesmo tempo.

Nesse período, os prefeitos dos municípios do Vale do Paraíba reuniram-se para discutir a idéia e criar um organismo que, associando os municípios que apresentavam objetivos comuns, promovessem o desenvolvimento dessa região.

Através da Resolução de 31 de março de 1964 e dos dispositivos inseridos na Constituição de 1987, tornou-se juridicamente possível o que já fora constatado no primeiro Plano Diretor de São José dos Campos, elaborado pelo CEPEU-USP: a 
inviabilidade de dar tratamento estritamente municipal a uma série de problemas característicos de âmbito regional. A lacuna evidente entre os níveis de poder municipal, estadual e federal que dificultava a solução dos problemas da área regional foi parcialmente coberta pela associação de municípios; entre eles, os do Vale do Paraíba em torno do CODIVAP, em 10 de outubro de 1970.

Em 1971, por meio do Consórcio do Desenvolvimento Integrado do Vale do Paraíba e Litoral Norte (CODIVAP) foi elaborado um diagnóstico do Vale do Paraíba pela caracterização e avaliação dos problemas existentes e sua situação, considerando cinco setores: ecológico, urbanístico, socioeconômico, sociocultural e institucional. Como resultado final, foi publicado o documento Caracterização e Avaliação dos Conhecimentos existentes sobre a Região do Vale do Paraíba e Diagnósticos Resultantes.

O CODIVAP era composto por 35 municípios, tinha sua sede na cidade de Pindamonhangaba e pregava a necessidade de se reunirem todos os municípios do Vale do Paraíba afligidos por problemas comuns e de difícil solução. Esse consórcio funcionou à maneira dos mais adiantados sistemas semelhantes implantados na Europa.

Dentre as principais atribuições, destacamos a ativação da Superintendência do Desenvolvimento do Vale do Paraíba (SUDEVAP), cuja proposta era a de proporcionar uma política de incentivos fiscais, criar um centro regional de abastecimento, execução conjunta de obras de interesse comum, promover o fomento industrial - este por meio de incentivos e financiamentos - criação de uma televisão educativa regional, implantação de um sistema habitacional regional - construção de casas populares - reflorestamento da região e promoção do desenvolvimento social.

O estudo sobre a caracterização do conhecimento do Vale do Paraíba teve como mérito apresentar uma metodologia de análise de conhecimentos sobre uma região específica - o Vale do Paraíba e ressaltar a escala de conurbação que vinha ocorrendo naquele período, indicando sua tendência futura. 
Essa caracterização foi elaborada para servir de base para que, governos e empresas privadas, utilizassem os conhecimentos ali agrupados para nortear suas decisões e elaborar um modelo de planejamento regional global. A primeira aproximação dos problemas foi feita por meio de uma sistematização dos conhecimentos já existentes sobre a caracterização da região em todos os aspectos que afetavam seu planejamento urbano.

Para a realização desta primeira etapa de trabalho, o CODIVAP contratou uma equipe de profissionais, incluindo 9 consultores, 14 técnicos, 24 pesquisadores e montou um escritório de coordenação. Esses profissionais, de acordo com suas especialidades, foram agrupados nos cinco setores estabelecidos: ecológico, urbanístico, socioeconômico, sociocultural e institucional.

Para garantir a unidade do trabalho e uma visão global, foi adotada como metodologia a realização de dois seminários com a participação de toda a equipe profissional e diretoria do CODIVAP. O primeiro foi o Seminário de Critérios que, durante três dias, reuniu elementos da equipe e permitiu aos diversos setores a delimitação de suas tarefas, uso de uma linguagem comum, estabelecimento de metas e critérios de coleta de dados.

O segundo foi o Seminário de Análise que, após a coleta, compilação e análise dos dados em cada setor, reuniu por dois dias toda a equipe para proceder a fusão das análises parciais e obter uma síntese daquilo que se pretendia com o trabalho. De início, os técnicos deparam-se com a necessidade de compartimentar a região do CODIVAP e proceder a análise.

Foram esboçadas duas compartimentações: uma surgiu da necessidade de sub-regionalização para análise de dados socioeconômicos agrupados de acordo com a divisão administrativa e, portanto, teve como unidade o município. A outra, a compartimentação ecológica serviu para a análise dos fatos ligados à paisagem, não podendo, portanto, conter-se aos limites administrativos e obedecer critérios de ordem 
geomorfológica, climática e hidrológica correlacionadas à ação do homem na região do Vale do Paraíba.

No Setor Ecológico, pretendeu ampliar o sentido de simples acervo de subsídios de geografia física e humana ao planejamento, tentando encarar as interrelações dinâmicas da paisagem com a ação do homem. A análise ecológica e a compreensão da dinâmica da paisagem, isto é, do meio, através dos elementos físicos, biológicos e da atuação do homem que, ao interagir, faz da paisagem um conjunto básico, único e indissociável em evolução. Esse enfoque foi necessário para se determinar as unidades ecológicas com homogeneidade fisionômica e dinâmica comum em que apresenta o mesmo tipo de evolução.

Esta ação foi importante para o planejamento global do Vale, especificamente, para seu planejamento rural. A tentativa de compartimentação ecológica apresentada, foi o resultado do estudo de três campos fundamentais por meio de múltiplos enfoques: o potencial ecológico, a exploração biológica e a ação antrópica. Para tanto, foram definidas três regiões ecológicas no Vale do Paraíba: a Fossa do Paraíba, a Mantiqueira e o Planalto Atlântico.

A Fossa do Paraíba, que corresponde ao Vale Médio do Paraíba, localizada em São José dos Campos, foi o compartimento básico que apresentou o maior índice de urbanização com os principais núcleos da rede urbana regional, onde se concentra praticamente toda a atividade industrial e a maior parte de sua exploração agrícola. Caracterizou-se, por outro lado, como eixo de circulação entre as duas maiores metrópoles brasileiras, Rio de Janeiro e São Paulo. A Fossa foi a área mais bem estudada sob múltiplos aspectos, porém, quanto à ecologia, os únicos estudos de detalhe estavam vinculados aos aspectos hidrológicos.

Em relação à região ecológica da Mantiqueira, esta foi constituída pela Serra do Planalto da Mantiqueira e, segundo os estudos, apresenta superfícies regularmente planas e planaltos como os de Campos do Jordão, maciços alcantilados, como o Itatiaia - 
Agulhas Negras, já no Estado do Rio de Janeiro. Sobre o Planalto Atlântico, esta foi a área marginal do Vale do Paraíba que constituía sua parte mais extensa, porém de povoamento menos efetivo, com fraca densidade, baixa urbanização e municípios bastante extensos.

O estudo elaborado pelo CODIVAP apresentou a análise de cada uma das regiões aqui relacionadas, bem como os geosistemas que as compõem, resultando daí cartogramas-síntese que apresentaram o esboço de compartimentação geo-ecológica do Vale do Paraíba.

O setor Urbanístico teve como objetivo verificar todo o processo de urbanização do Vale dentro de uma visão regional, analisando suas relações internas e externas. Também teve como meta a verificação do grau de conhecimento existente no Vale do Paraíba sobre os problemas de urbanização e estabeleceu critérios para complementação desse conhecimento. Com a preocupação de acelerar a intervenção, foram estabelecidas medidas passíveis de serem planejadas, objetivando estancar tendências negativas, aumentar a arrecadação ou adotar critérios de prioridade.

A pesquisa desenvolveu-se em duas etapas: levantamento de dados, análise e proposições. Dentro do campo urbanístico, setor prioritário, foi desenvolvido um subsetor de cadastro que recebeu tratamento de anteprojeto, dada a consciência prévia da grande necessidade de cadastramento dos municípios da região. Destacam-se, nesse capítulo do estudo do CODIVAP, as observações locais e a dinâmica urbana.

Em relação às observações locais e em decorrência de uma série de informações que não foram incluídas na tabulação dos dados - por não servirem para a avaliação do grau do conhecimento - foram agrupadas no sub-título "as observações locais" a fim de permitirem a individualização dos problemas municipais, subsidiando um programa de intervenção a curto prazo. Sobre a dinâmica urbana, foi examinada a dinâmica de ocupação do solo e o transporte do Vale do Paraíba, a fim de avaliar polarizações e tendências a conurbações, além de outras alterações. Concluiu-se que 
uma melhor compreensão da dinâmica inter-regional permitiria também avaliar o enquadramento do Vale do Paraíba, no todo ou em partes, como áreas metropolitanas.

O primeiro grupo de cidades, denominada $1^{\mathrm{a}}$ sub-região, composta pelas cidades de Jacareí, São José dos Campos, Caçapava e Taubaté já apresentava intensa urbanização ao longo da Via Dutra, com fábricas novas e o surgimento de bairros afastados dos núcleos urbanos, trazendo consigo problemas específicos de infraestrutura urbana. Esse grupo de cidades mostrou-se fortemente ligado à Via Dutra com três estruturas físicas paralelas cortando a trama urbana: o rio, a estrada de ferro e a rodovia.

O CODIVAP analisou os movimentos diários entre as cidades do Vale do Paraíba e sua dinâmica urbana, possibilitando realizar um prognóstico das conurbações da região, considerandos três tipos de aproximação urbana:

1) proximidades físicas, traduzindo-se em conurbações iminentes;

2) proximidades relativas, determinando sistema de conurbação possível, dependendo da política territorial a ser adotada;

3) aproximação de dependência, criando uma relação de absorção de funções.

No aspecto socioeconômico, foram feitas análises dos cadastros existentes nos municípios da região do CODIVAP, sendo adotado como parâmetro básico o critério do cálculo do valor venal, por ser o indicador que define a maior parte dos dados a serem levantados. Os cadastros encontrados foram agrupados em cinco sistemas diferentes, de acordo com as possibilidades e peculariedades dos municípios que os empregavam.

A observação desses sistemas de cadastro resultaram nas seguintes conclusões de ordem geral: a) os cadastros desses municípios apresentavam função meramente fiscal; b) as rotinas de atualização são indefinidas e assistemáticas; c) a inexistência de bases cartográficas torna-os desatualizados; d) a ineficiência dos métodos do cálculo do valor venal induz o cadastrador ao emprego de critérios 
subjetivos; e) a implantação de uma sistemática de cadastro se torna inoperante devido a inexistência de manuais de operação.

O CODIVAP considerou para o primeiro grupo, do qual faz parte São José dos Campos que, em decorrência do crescimento urbano eram necessários altos investimentos em infra-estrutura. Esses municípios deveriam orientar sua política fiscal no sentido de atualizar seus cadastros e aperfeiçoar o método de calcular o valor venal melhorando, dessa forma, a arrecadação sem acréscimo de alíquotas.

O aspecto sociocultural teve como meta correlacionar o patrimônio cultural da região, o potencial humano, o folclore e artesanato existente, instituições culturais e monumentos históricos dentro do seu ajustamento, aproveitamento o desenvolvimento da região.

O setor Institucional foi o que recebeu maior atenção por parte dos técnicos, devido à falta de legislação específica e moderna que permitisse o trato comum de problemas entre municípios, problemas estes que se situavam fora da órbita estadual e federal e, por sua vez, já extravasavam os limites jurídicos municipais. Ao setor institucional também coube a visão global da implementação para todas as medidas preconizadas nos diversos campos, uma investigação na organização administrativa e financeira dos municípios e uma análise do próprio CODIVAP, como órgão de planejamento, coordenando os esforços municipais com os das áreas federal, estadual e privada com o objetivo único do desenvolvimento integrado da região do Vale do Paraíba.

O estudo de caracterização do conhecimento do Vale do Paraíba elaborado pelo CODIVAP apurou as seguintes considerações sobre: população, urbanização, infraestrutura, setor terciário, dinâmica urbana e ocupação do solo.

1) População: a população do Vale, entre 1940 e 1970, passou de 396 mil para 830 mil habitantes, apresentando um crescimento de $109 \%$, o que representa uma taxa geométrica anual de 2,5\%. Esse crescimento foi, principalmente, o resultado da grande queda da mortalidade. Em relação 
à população da primeira região, que inclui a cidade de São José dos Campos, ficou constatado que essa triplicou naquele período, sendo uma metade do acréscimo devido ao crescimento vegetativo e a outra à imigração. A análise das migrações mostra que a $1^{\mathrm{a}}$ sub-região foi a única que atraiu um considerável número de imigrantes ao longo de todo o período.

2) Urbanização: embora o Vale do Paraíba como um todo não apresente saldos migratórios muito grandes, há fortes movimentos migratórios internos, com grandes contingentes se dirigindo às cidades, dando origem a intensa urbanização. Entre 1940 e 1970, a população urbana do Vale cresceu 305\%, quase três vezes em relação à população total. A parcela da população que era urbana subiu de $37,9 \%$ em 1940 , para $73,2 \%$ em 1970. A urbanização se deu, principalmente nas cidades maiores: São José dos Campos, Taubaté e Jacareí. A população dessas cidades representava apenas $7,1 \%$ do total em 1940 , porém esta porcentagem chegou a 50\% em 1970, tornando o Vale uma área com forte característica urbana, mais acentuada que o restante do Estado de São Paulo.

3) Infra-estrutura: o Vale do Paraíba é cortado por dois eixos principais e paralelos de transportes: a Estrada de Ferro Central do Brasil e Rodovia Presidente Dutra.

4) Setor Terciário: entre 1940 e 1970, o setor terciário estava começando e o comércio atacadista era de pouca significação, sendo concentrado na capital que exercia as funções de centro atacadista para grande parte do interior do Estado. O estudo considerou de que um dos resultados da urbanização parecia ser o crescimento rápido dos estabelecimentos maiores, o que refletia a melhoria de qualidade do comércio varejista da 
região, mas que teria sua contrapartida no crescimento do comércio não estabelecido.

Entre 1960 e 1969, verificou-se considerável expansão da rede bancária do Vale e constatou-se que a $1^{a}$ sub-região concentrava mais da metade do movimento bancário da região. O estudo ressalvou que, por meio dos dados levantados, não havia dúvidas de que a principal vocação econômica do Vale do Paraíba era a industrial.

Estando o Vale entre as duas maiores metrópoles do país e sendo um centro de redistribuição de tráfego para o Litoral Norte e Serra da Mantiqueira, o fomento de outras atividades econômicas que não a indústria deve ter necessariamente partido da situação geográfica da região.

5) Dinâmica urbana: esse capítulo do estudo limitou-se a examinar a dinâmica de ocupação do solo e o transporte dentro do Vale do Paraíba com o intuito de avaliar polarizações, tendências, conurbações ou outras alterações. Por meio dessa ótica, o trabalho pode estabelecer o âmbito de planos integrados ou setoriais que venham a ser elaborados ou revistos: se uma cidade torna-se fortemente polarizadora, a prioridade aumenta; se duas cidades tendem a conubanizar-se, suas diretrizes viárias e a estratégia de desenvolvimento devem ser compatibilizadas; se entre grupos de cidades há intensa comunicação diária, alguns sistemas poderiam fornecer melhores serviços, se unificados; e assim por diante.

Uma melhor compreensão desta dinâmica intra-regional permitiria, igualmente, avaliar a oportunidade de inserir o Vale do Paraíba no todo ou em parte, no enquadramento proposto pela lei que cria áreas metropolitanas. Em outros termos, poder-se-ia examinar a oportunidade de propor, pioneiramente, alterações polítco-administrativas toda vez que tal 
alteração significasse reais ganhos, em longo prazo, no desenvolvimento socioeconômico e das condições de vida dos habitantes do Vale do Paraíba.

6) Ocupação do solo: o crescimento das cidades da $1^{\text {a }}$ sub-região deu-se de forma rápida por imigração e urbanização. A ocupação do solo revela que, de um modo geral, havia um florescimento das atividades imobiliárias e loteamentos. O mecanismo típico, imediatista e desconectado de qualquer estratégia ou plano levou a um crescimento incoerente e oneroso para a implantação de serviços e redes. Curioso é que, naquele período, a ocupação do solo em São José dos Campos estava bem descrita no diagnóstico do Plano Integrado.

Condicionada pelo sítio, cuja plataforma cai em falésia sobre o Banhado limitado pela Via Dutra, o solo disponível se estrangula a Nordeste e Sudoeste, onde a expansão era tamponada pela fábrica da General Motors e o terreno da Ford. O preenchimento de vazios, organização do Vale dos Lavapés, preparo para ultrapassar a Dutra (setor Kanebo) demandando Jacareí pela estrada velha Rio -São Paulo e o aumento da densidade, são os quatro pontos constatados e propostos pelo Plano Integrado para a ocupação territorial. A fim de estruturar esta nova ocupação, era necessário estabelecer, qual coluna vertebral, um eixo viário no sentido Sudoeste-Nordeste, mediante a junção de algumas vias já existentes. Essa alteração estrutural inverteria o eixo de ocupação que vinha ocorrendo naquele período.

A $1^{a}$ sub-região sofreu, nesse período, intensa urbanização ao longo da Via Dutra, em boa parte motivada pela localização de fábricas novas que pontilhavam suas margens. A oferta de emprego e, especialmente, a perspectiva de bons negócios ao se 
parcelar pedaços do solo rural ao lado do terreno de uma fábrica, são fatores que provocaram o surgimento de bairros afastados dos núcleos urbanos.

Esta característica resultou em fatos típicos e, nem sempre, positivos, tais como o uso intenso da Via Dutra como via urbana, ônibus intermunicipal usado para ligações domicílio-trabalho, elevado custo da extensão das redes de abastecimento.

Surgiu, assim, a necessidade de examinar o problema da ocupação e uso do solo, não apenas dentro dos planos municipais, mas também de forma agrupada e subregional e foram adotadas políticas compatibilizadas. Esta compatibilização não foi simples, em nível de tributação, mas foi necessária para possibilitar o atendimento em infra-estrutura e garantir um nível de vida digno para os habitantes das periferias.

Analisando o estudo desenvolvido pelo CODIVAP pudemos verificar que este foi o primeiro plano para a região do Vale do Paraíba que tinha como objetivo um planejamento regional integrado proposto através da sistematização de dados e informações que conduzisse a região para um pleno desenvolvimento econômico.

Com relação à metodologia adotada pelo CODIVAP a análise dividia a área do conhecimento em cinco setores, conforme já descrito anteriormente, e pudemos notar que, dentro das características específicas a cada um desses setores, os estudos desenvolvidos não apresentavam homogeneidade de tratamento. Verificamos que o setor urbanístico apresentou dados sobre o conhecimento e sugeriu algumas ações. O mesmo não foi verificado para os setores ecológico, socioeconômico e sociocultural em que a metodologia definiu apenas as diretrizes para um conhecimento da região e não propôs soluções para os problemas levantados pelo estudo.

De maneira geral, os setores abordados apresentavam os problemas e recomendações da região do Vale do Paraíba, mas não sugeriam soluções. Em síntese, a criação do CODIVAP visou a coordenação dos esforços municipais, estaduais, federais e privados da região do Vale do Paraíba paulista, no sentido de promover seu pleno desenvolvimento. 


\subsubsection{O Plano Regional para o Macro-Eixo Paulista}

Em 1978, coordenado pela Secretaria de Estado da Economia e Planejamento foi elaborado o Plano Regional Macro-Eixo Paulista, que caracterizou-se como uma das formas de execução da Política de Desenvolvimento Urbano e Regional PDUR, aprovada pelo Conselho de Governo, em janeiro de 1976, cujas diretrizes básicas estão definidas na Política Nacional de Desenvolvimento Urbano, fundamentadas no II PND.

Entre as diretrizes do II PND, com referência à área do Macro-Eixo, destacam-se: a) coordenar os investimentos e regulamentar o uso do solo, de modo a conter as taxas de crescimento das metrópoles - Rio e São Paulo; b) induzir a descentralização das atividades produtivas, particularmente as industriais, para centros periféricos de médio porte; c) disciplinar a ocupação urbana e rural entre o Rio de Janeiro e São Paulo e d) planejar e disciplinar o processo de urbanização da orla marítima, visando ao turismo, ao lazer, bem como a preservação das belezas naturais, cidades históricas e estâncias hidrominerais.

Salienta-se que o Plano do Macro-Eixo foi elaborado no momento que as forças sociais começavam a pressionar o fim da Ditadura e fez as seguintes considerações:

1) que a dimensão dos problemas sociais, propostos por meio das condicionantes sociais, apresentassem dois níveis: o primeiro relativo à divisão social do trabalho e o segundo à divisão territorial;

2) a concentração da renda e a concentração espacial das atividades era uma realidade dentro do sistema econômico vigente no Brasil;

3) a atual fase do desenvolvimento econômico brasileiro se caracterizava pelo enfraquecimento relativo dos setores rurais e pelo fortalecimento relativo dos setores econômicos urbanos (industrial e de serviços). 
Pudemos verificar, ao elencar os objetivos do Plano Macro-Eixo Paulista, que este pretendia, por meio de suas diretrizes, integrar a ação dos diferentes órgãos governamentais envolvidos na problemática de desenvolvimento da região do Vale do Paraíba.

O Plano Regional era vinculado ao Programa Macro-Eixo Rio-São Paulo que era conduzido pela Secretaria de Economia e Planejamento do Estado de São Paulo e tinha ligações com a Comissão Nacional de Política Urbana (CNPU) e o órgão da Secretaria de Planejamento da Presidência da República.

A área do Macro-Eixo, em seu segmento paulista, situava-se entre a Grande São Paulo e o Estado do Rio de Janeiro, estendendo-se desde a Serra da Mantiqueira até o Litoral Norte, sendo cortada em toda a sua extensão pelo Rio Paraíba do Sul e pela Rodovia Presidente Dutra. A área abrangida pelo Plano Regional compreendia 36 municípios, agrupados em cinco sub-regiões. São José dos Campos encontra-se na Subregião 2 denominada de Médio Vale-Eixo da Dutra.

O Plano apontou que, nas décadas de 1960 e 1970, ocorreu um grande crescimento urbano-industrial ao longo do eixo da Via Dutra em decorrência da própria condicionante física, da indução da rodovia e do movimento de desconcentração industrial da área metropolitana.

O Plano também apresentou que, a falta de intervenção reguladora do processo que vinha ocorrendo em um ritmo acelerado, denominado pelos seus organizadores como um Cenário Espontâneo, teve como proposta os seguintes aspectos: a) concentração crescente da indústria nos municípios próximos da Grande São Paulo, gerando um aumento dos desequilíbrios econômicos e sociais; b) um padrão de urbanização acelerado e do modo desordenado ao longo da Via Dutra e Litoral Norte, com acúmulo de déficit de infra-estrutura; c) níveis maiores de poluição no Rio Paraíba e ocupação crescente de sua várzea por atividades industriais e urbanas e d) degradação do solo e da vegetação. 
Face a essa realidade, o Plano Regional Macro-Eixo Paulista estabeleceu uma série de diretrizes e propostas de intervenção governamental orientadas para a concretização de um crescimento ordenado e consubstanciado à visão de um "Cenário Desejável" que traduzia um novo padrão de localização industrial mais descentralizado e ordenado ao longo do eixo da via Dutra; um novo esquema de urbanização ordenada em que as conurbações fossem estruturadas ao longo da Via Dutra e uma expansão urbana controlada no Litoral Norte e a utilização racional dos recursos naturais da Região do Vale do Paraíba que visava a recuperação e proteção dos recursos hídricos, do solo, da vegetação e proteção das várzeas para fins agrícolas.

Frente às necessidades detectadas por esse Plano foram elaboradas diretrizes e propostas resumidas e apresentadas em quatro grupos, todas vinculadas à política de desenvolvimento para a Região do Vale do Paraíba.

O primeiro grupo de diretrizes foi orientado para a continuação e aprimoramento das medidas governamentais pertinentes ao processo de descentralização industrial, na medida em que a industrialização foi considerada como elemento motriz do processo de urbanização acelerado, especialmente ao longo da Via Dutra e pelas suas implicações na preservação dos recursos naturais e na qualidade de vida dos habitantes dessa região.

A indicação de novas áreas prioritárias para o assentamento industrial e para a expansão urbana ordenada, bem como as medidas que orientam o uso racional dos recursos naturais dessa região, fundamentou o segundo grupo de diretrizes.

O terceiro grupo de diretrizes envolveu os aspectos da estrutura de base, correspondendo-Ihe medidas e propostas vinculadas à infra-estrutura viária, social e econômica. Estas deveriam ser, preferencialmente, implantadas em núcleos urbanos, tidos como prioritários, na estruturação da ocupação urbana ordenada e dar condições de apoio ao fomento do turismo e da atividade agropecuária regional. Procurou-se também, 
implementar objetivos econômicos e sociais de atendimentos urbanos ligados aos setores de saneamento, habitação, saúde e educação.

Entretanto, a implementação do Plano Regional, segundo a concepção proposta, implicava a necessidade de uma nova atuação governamental na área. Nesse sentido, o quarto grupo de diretrizes relacionou-se à administração e finanças públicas, planejamento e, em especial, às medidas jurídico-institucionais alternativas, julgadas necessárias para uma maior eficiência do sistema de planificação. Entre as principais medidas jurídicas que foram recomendadas estão: legalização de uso do solo, de zoneamento industrial, de proteção dos mananciais e proteção da várzea para fins agrícolas.

1) O Macro-Eixo e os condicionantes para uma política regional

O Plano do Macro-Eixo paulista propôs que, para qualquer perspectiva que se desejasse sobre a futura distribuição espacial da atividade econômica no Estado de São Paulo, do qual a região metropolitana da Grande São Paulo era a grande caracterizadora necessário seria entender a lógica do processo a ela vinculada. Exigiu, pois, para seu entendimento o conhecimento dos fatores intervenientes desse processo.

O plano também evidenciou dois fatores como responsáveis pelo início do processo de urbanização e crescimento na região do Vale do Paraíba: vantagens locacionais e fatores internos com responsabilidade no crescimento da demanda.

A partir do pressuposto que o início do processo de urbanização e/ou a sua aceleração poderia se dar a partir da exploração das vantagens locacionais que uma comunidade pode oferecer para uma indústria em particular, a produção, suportada de início por demanda externa, cresce, fazendo-se acompanhar, em razão das maiores oportunidades de emprego, do aumento da força de trabalho e, conseqüentemente, de maior densidade populacional. Some-se a isso o crescimento de renda e ter-se-á outra classe de estímulo à urbanização e ao crescimento. População e renda crescente dentro 
da comunidade geram demanda local, que, por seu turno, estimula a produção e o crescimento locais, inclusive, substituição de importações.

Portanto, o processo de crescimento e urbanização dinamizam-se impulsionados por fatores de produção e, especialmente, pelas novas decisões de localização e investimentos, muitas das quais em função de implementação cumulativa.

Nessa perspectiva, vantagens locacionais e fatores determinantes de crescimento interno de mercado ajudam não somente a explicar as transformações de uma região, como também lançam luz sobre a urbanização de toda uma região ou nação.

Em relação à organização territorial, as cidades do Vale do Paraíba, em particular aquelas localizadas ao longo do eixo da Via Dutra, na primeira fase de industrialização, tiveram sua evolução praticamente dependente do grande centro polarizador, São Paulo.

2) O Macro- Eixo e a descentralização industrial

O Plano do Macro-Eixo Paulista registrou que a região da Grande São Paulo, naquele período, já apresentava uma leve perda de participação no total da atividade industrial e que continuava respondendo, ao longo do período de elaboração desse Plano, por cerca de 70\% da formação da mesma.

Pudemos constatar que, quando da elaboração do Plano Macro-Eixo, já havia um processo de deslocamento gradual do setor secundário rumo ao interior, cuja expressão aconteceu em função da perda de participação relativa dessa área no total da atividade industrial.

Portanto, naquele período, a Grande São Paulo já vinha apresentando taxas de crescimento menores que o conjunto das demais regiões da Macro-Metrópole, caracterizadas nesse processo, como receptoras do movimento de desconcentração. Iniciou-se um movimento de ocupação espacial das áreas fora da Grande São Paulo, em especial nas regiões de Campinas e Vale do Paraíba, seguidas do Litoral e Sorocaba. Em síntese, as tendências definidas de ocupação espacial são no sentido de uma 
desconcentração gradual e com perspectivas de aceleração, direcionadas à periferia da Grande São Paulo.

3) O Macro-Eixo e a infra-estrutura urbano-industrial e planejamento setorial

O Plano apresentou o estudo da infra-estrutura que era essencial e deveria ocorrer antes da preparação de uma política de desenvolvimento para a região, tanto no que se refere ao conhecimento da situação atual, como dos planos estabelecidos pelos órgãos setoriais responsáveis.

Dada a importância da existência de condições compatíveis de infra-estrutura econômica para a viabilização dos processos de urbanização e industrialização, qualquer política que viesse a ser adotada pelo Plano Regional necessitava do conhecimento prévio dessa infra-estrutura e das intenções dos órgãos setoriais responsáveis, para ser convenientemente formulada e levar ao estabelecimento de propostas viáveis. Não podemos esquecer que para que um planejamento setorial seja eficiente este deve possuir uma estrutura suficientemente articulada.

4) O Macro-Eixo Paulista e a evolução da ação governamental na região:

O Plano do Macro-Eixo apresentou como interesse imediato a produção de insumos para uma política de desenvolvimento na região e, para tanto, recomendou que fossem considerados e abordados os seguintes aspectos:

1) A maneira como o Estado participa no processo de desenvolvimento da região;

2) O reflexo dos processos de urbanização e industrialização na capacidade de arrecadação tributária do Estado na região;

3) As mudanças internas na atuação do Estado, referentes às relações entre os três níveis de governo;

4) As implicações de experiência recente de atuação governamental na região, para a atividade de planejamento. 
Os aspectos indicados levaram à conclusão de que os processos de industrialização e urbanização que vinham ocorrendo na região do Vale do Paraíba e, mais especificamente, em São José dos Campos em ritmo acelerado, bem como o processo de desruralização, refletem implícita ou explicitamente, um modo determinado de atuação do Estado na região, atuação que também envolveu mudanças e contradições internas nas relações entre os três níveis de governo.

Nesse período, 1978, começou a ser elaborada a lei de zoneamento que iria substituir a lei $\mathrm{n}^{0}$ 1606/71.

Analisando o Plano, pudemos constatar que esse expressava, através de suas propostas, um Plano Regional de Desenvolvimento Integrado que servia de apoio e diretriz às medidas posteriormente adotadas pelos municípios e pelo próprio Estado, especialmente pelo uso e ocupação do solo de maneira ordenada e mais harmônica, em nível local e regional.

Em relação ao aspecto metodológico, o Plano Macro-Eixo apresentou três etapas de trabalho: estudos básicos, prognósticos, diretrizes e propostas. Destacamos a qualidade dessa metodologia aplicada pelo plano em relação à simplicidade e a capacidade de seus organizadores em apoiar diversas e complexas análises na organização da estrutura espacial da rede urbana paulista.

O Plano concluiu que, dada a importância da existência de condições compatíveis de infra-estrutura econômica para a viabilização dos processos de urbanização e industrialização, qualquer política que viesse a ser adotada pelo Plano Regional do Macro-Eixo necessitava do conhecimento prévio dessa infra-estrutura e das intenções dos órgãos setoriais responsáveis.

\subsubsection{Macrozoneamento - CEEIVAP}

Após a conclusão do Plano Regional Macro-Eixo Paulista, o CEEIVAP (Comitê Executivo de Estudos Integrados da Bacia Hidrográfica do Rio Paraíba do Sul), 
através do Projeto Gerencial CEEIVAP 0003/79, estabeleceu as Diretrizes de Ordenamento da Bacia Hidrográfica do Rio Paraíba do Sul.

Esse projeto visava um desenvolvimento harmônico para a região do Vale do Paraíba e, para que isso fosse possível, era necessário que o uso e a ocupação do solo do espaço regional fosse elaborado de maneira ordenada e adequada para as mais diversas atividades e, principalmente, compatibilizadas com diretrizes específicas para a proteção ambiental da região.

A principal contribuição desse documento foi a de que seus organizadores acreditassem que, através do caráter de orientação do disciplinamento do uso do solo fossem indicados os usos preferenciais de ocupação nessa região e que compatibilizasse o desenvolvimento com a proteção ambiental.

Muito mais que resultados definitivos, as conclusões tiveram o caráter de subsidiar a elaboração de políticas de todos os níveis governamentais envolvidos naquele processo de planejamento e, principalmente, à complementação da legislação vigente no Estado de São Paulo, Minas Gerais e Rio de Janeiro, aos sistemas de licenciamento de atividades poluidoras e à elaboração de legislação específica.

Por fim, esse projeto apresentou uma clara preocupação sobre o controle e a organização que mostrava ser um planejamento voltado para os resultados e os subsídios para discussão do crescimento harmônico e integrado da região e serviria, de certa forma, como base para o desenvolvimento do projeto do macrozoneamento do Vale do Paraíba a ser desenvolvido pelo INPE, assunto que trataremos no item 3.1 .5 a seguir.

\subsubsection{O Plano Regional - MAVALE}

O MAVALE foi elaborado pelo Instituto de Pesquisas Espaciais - INPE e pelo Consórcio de Desenvolvimento Integrado do Vale do Paraíba e Litoral Norte do Estado de São Paulo - CODIVAP. 
Iniciado em 1989, foi estruturado para atingir dois objetivos específicos: dar suporte ao CODIVAP na elaboração de diretrizes de ordenamento do uso do solo regional e o de colocar à disposição da comunidade técnico-científica do país uma metodologia de planejamento regional baseada no uso do sensoriamento remoto orbital.

O processo acelerado de industrialização transformou o Vale do Paraíba e, diante do risco ambiental que poderia acompanhar esse processo, o governo federal, o CODIVAP e o INPE mostraram a necessidade de ser elaborado um macrozoneamento da região.

O governo federal por meio do Decreto $n^{0} 87.561$, de 13 de setembro de 1982, estabeleceu ações e medidas para a recuperação e proteção ambiental da área correspondente à Bacia Hidrográfica do Rio Paraíba do Sul.

Também em 1969, o Governo do Estado de São Paulo firmou convênio com o Ministério do Interior com a coordenação da Secretaria de Obras e do meio Ambiente (SOMA). As diretrizes resultantes desse levantamento deveriam, por meio de legislação municipal específica, serem incorporadas aos Planos Diretores de desenvolvimento integrado dos municípios do Vale do Paraíba e de seus programas municipais.

O estudo foi orientado para elaboração de diretrizes de ordenamento do uso da terra regional que conduziria a um desenvolvimento mais equilibrado e harmônico da região do Vale do Paraíba, bem como à proteção ambiental, de modo que tais diretrizes pudessem satisfazer as necessidades da população e que a utilização dos recursos naturais não fosse comprometida.

Os primeiros esforços de planejamento integrado no Vale do Paraíba dirigidos para o desenvolvimento regional foram decorrentes da associação dos municípios em torno do CODIVAP, em 10 de outubro de 1970. Esta ação concretizava os anseios dos prefeitos de municípios do Vale que, pelos idos de 1961, começaram a reunir-se para discutir a idéia de criar um organismo que associasse os municípios com objetivos 
comuns e promovesse o desenvolvimento regional. O propósito buscado naquele tempo era o pleno desenvolvimento.

Inicialmente, concentraram-se na reunião de conhecimentos e dados da região do Vale do Paraíba e culminaram com a publicação do documento Caracterização do Conhecimento do Vale do Paraíba, CODIVAP (1971). O planejamento regional, nessa região, realizou-se por meio do Plano Regional do Macro-Eixo Paulista, elaborado pela Secretaria de Economia e Planejamento do Governo do Estado de São Paulo (São Paulo, 1978). Com esse plano objetivava-se um desenvolvimento mais equilibrado e integrado do Vale do Paraíba e Litoral Norte face à política de desenvolvimento urbano e regional do Estado, voltada para a descentralização da área metropolitana de São Paulo. Naquela época, esboçava-se como enfoque secundário ao desenvolvimento regional, a necessidade de proteção e recuperação das riquezas naturais regionais.

Posteriormente, um novo e relevante esforço de planejamento regional foi realizados pelo CEIVAP - Comitê Executivo de Estudos Integrados da Bacia Hidrográfica do Rio Paraíba do Sul, por meio do Projeto Gerencial 0003/79 (CETESB, s/d). Esse Comitê chegou ao estabelecimento das diretrizes para um macrozoneamento do uso do solo na Bacia do Paraíba do Sul, tendo em vista compatibilizar seu desenvolvimento com a proteção ambiental.

O último registro de planejamento regional para o Vale do Paraíba foi o Projeto MAVALE de 1992. Esse trabalho foi desenvolvido basicamente para realizar a atualização do macrozoneamento realizado pelo CEIVAP, na porção paulista da Bacia, estendendo-o aos demais municípios.

Essa iniciativa conjunta entre o INPE e o CODIVAP foi também um novo exemplo histórico de autodeterminação dos prefeitos consorciados, o que demonstrou que estes se mantiveram conscientes da importância do planejamento regional e da necessidade de revitalizá-lo como processo balizador das decisões municipais. 
Muitos problemas econômicos, sociais, demográficos, ambientais e físicoterritoriais extrapolavam os limites dos municípios e o enfoque regional para sua solução produziria resultados mais eficientes que tratamentos estritamente locais. A associação de prefeitos na busca de objetivos comuns deu força às reinvidicações políticas e viria a facilitar a implantação de ações corretivas e preventivas.

A visão global e regional foi essencial para nortear as ações locais tomadas ao nível municipal. A compreensão do papel de cada município, no contexto regional mais amplo, foi fundamental para fazer com que as medidas fossem tomadas em benefício de todos.

1) O MAVALE e a Ação Regional

Durante o estudo do Macrozoneamento do Vale do Paraíba (MAVALE), o planejamento regional foi entendido como um processo destinado a produzir um cenário regional ou uma futura realidade regional desejada, que não deveria ocorrer a menos que alguma coisa seja feita. Se o curso natural dos acontecimentos for produzir o futuro desejado, então não há necessidade de planejar. Este processo se faz necessário quando as tendências observadas apontam para cenários indesejáveis que podem ser evitados por meio de ações corretivas e/ou preventivas.

O planejamento foi concebido como um processo voltado para a consecução da realidade futura desejada e pressupõe a habilidade humana de influenciar e direcionar suas atividades, pelo menos dentro de alguns limites.

O projeto MAVALE foi desenvolvido e concebido dentro desse escopo de discussão e teve a finalidade de aumentar o conhecimento disponível acerca da região, identificou e localizou problemas e analisou tendências e, também, levantou informações que permitiram delinear algumas alternativas de ação para que fosse construído um cenário futuro desejado pelos seus organizadores. 
Naquele período, o cenário da região apresentava problemas de planejamento, parte dos quais tinham sido identificados em estudos regionais anteriores. Entre outros, exemplificam-se:

1) estagnação econômica de vários municípios;

2) saldos migratórios negativos e históricos nestes municípios;

3) expansão urbana acelerada e desordenada, em outros;

4) poluição dos recursos hídricos superficiais e subterrâneos por esgotos domésticos e industriais, disposição de rejeitos sólidos;

5) retração de áreas de agricultura em terrenos propícios de várzea;

6) desmatamento em áreas de proteção permanente;

7) aumento dos reflorestamentos em áreas propícias à agricultura;

8) degradação de importantes ecossistemas litorâneos;

9) uso e ocupação inadequados de terrenos sujeitos à erosão contínua, o que provoca aceleração dos processos erosivos, criando áreas sujeitas a escorregamentos / deslizamentos.

Parte destes problemas já aparecia em diagnósticos anteriormente realizados, de forma concentrada espacialmente e agravada, o que demonstrava uma tendência crescente de criticidade. Acreditava-se que, por meio de ações planejadas, seria possível orientar as mudanças necessárias para alcançar finalidades que implicassem em maior bem-estar da população residente. O alcance das melhorias passava, sem dúvida, pela necessidade de uma reorganização global e equilibrada do conjunto das atividades humanas no Vale do Paraíba.

O Plano MAVALE elaborou um diagnóstico socioeconômico com dois propósitos básicos: a) identificar o papel da região de estudo no contexto estadual, analisando seu comportamento frente às regiões administrativas do Estado; b) identificar com que equilíbrio e harmonia ocorriam o comportamento dos municípios da região. Nesta etapa, foram analisados dados demográficos, econômicos e sociais e, a partir de 
inúmeros levantamentos e análises das fotos de satélite, foi feito um mapa das aptidões físicas do Vale do Paraíba.

O mapa final de macrozoneamento foi elaborado para corrigir possíveis distorções encontradas no uso da terra regional face à sua potencialidade para outros usos e a possibilidade de proteção do meio ambiente, diante de ações antrópicas indesejáveis, bem como respeitar as áreas naturais sob proteção na região.

Com base nesse produto foi elaborada, no Plano de 1995, uma Carta do Macrozoneamento, específica para o uso e ocupação do solo do município de São José dos Campos, assunto que será retomado no Capítulo 4.

\section{2 Âmbito Municipal}

\subsubsection{A primeira Lei de Zoneamento de São José dos Campos}

Como apresentado no Capítulo 2, item 2.2 - Evolução Urbana de São José dos Campos, foi a partir da década de 40 que a cidade passou a ter um traçado pautado pela continuidade espacial, quadras regulares e vias amplas e ortogonais. A distribuição espacial da urbanização adentrou os anos 40 com características de tecido misto serviços, comércios e residências e uma forte presença, quanto ao porte e localização intra-urbana, de instalações industriais.

Temos, até a década de 1950, segundo período da evolução, um maior desenvolvimento urbano nas regiões periféricas do núcleo original e na parte Norte da cidade, onde se instalaram as primeiras grandes indústrias (Tecelagem Parahyba e Rhodia) e o início do processo de industrialização e de urbanização mais intensos, cujo impacto causado na área urbana do município, em decorrência desse processo, foi muito grande.

Os novos loteamentos que surgiam no início da década de 70 não se detiveram nas proximidades do núcleo urbano, uma vez que atingiram locais distantes e 
tomaram a direção da Via Dutra, onde as novas indústrias se instalavam, o que deu origem a uma faixa industrializada, intercalada por loteamentos residenciais, sem quaisquer melhoramentos que invadiam, muitas vezes, áreas produtivas da Zona Rural.

Podemos observar pela Fig 3.1 que essa faixa intercalada se mantém até hoje, apesar de existir uma legislação que incentivava a não ocupação dessas áreas localizadas entre as indústrias.

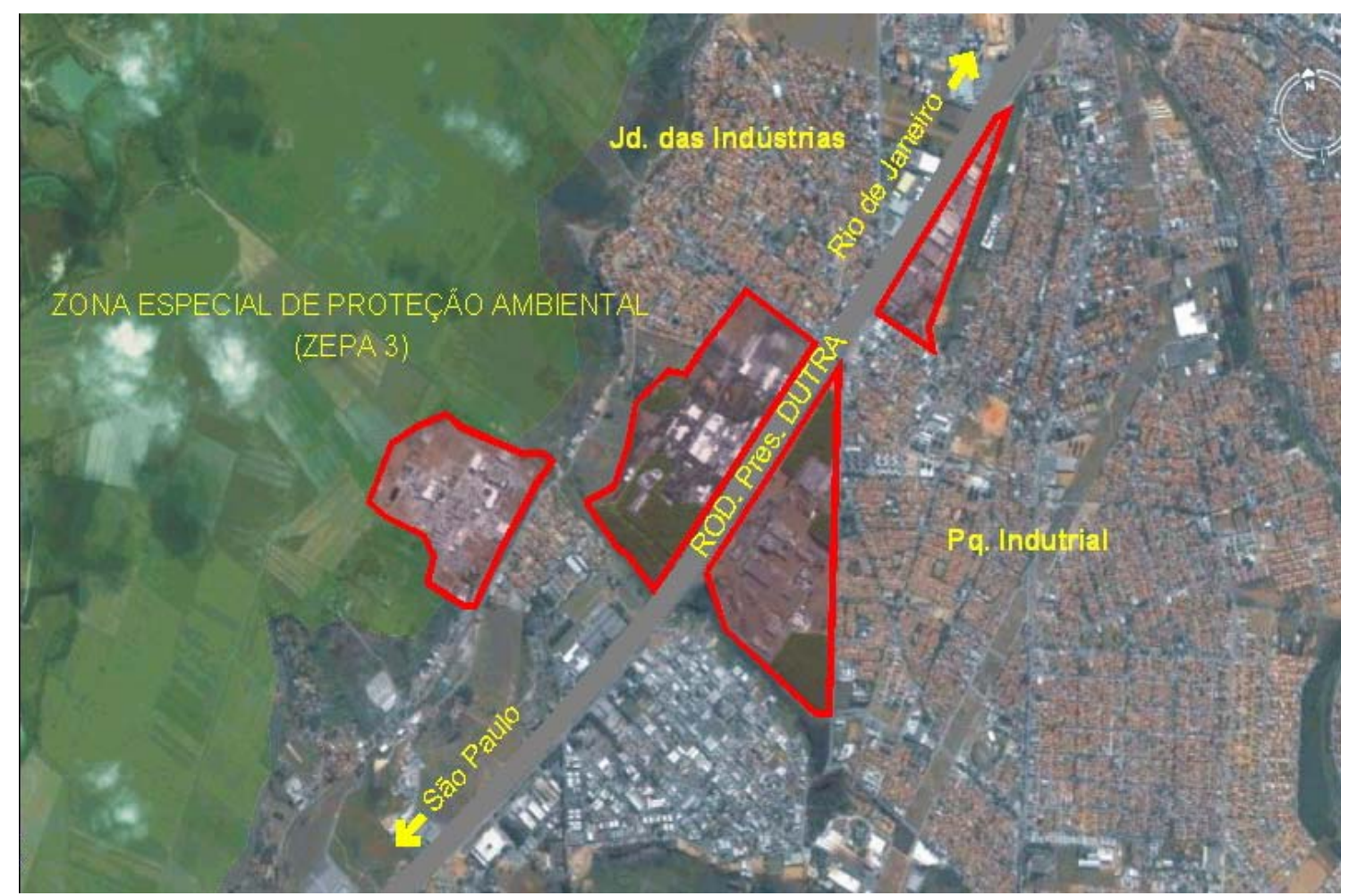

Figura 3.1 - Faixa industrializada ao longo da Via Dutra Fonte: Google, 2006.

Devido ao descontrole do crescimento urbano e a falta de uma legislação que disciplinasse o uso e a ocupação do solo da cidade, o Prefeito Benoit Almeida Vitoretti promulgou a Lei Municipal no 381, em 11 de janeiro de 1954, que instituía o Código de Obras destinado a regulamentar todas as disposições sobre construções, demolições, abertura de ruas e loteamentos e, principalmente, proteger a população dos possíveis incômodos advindos das atividades industriais, sendo esta a primeira tentativa de ordenar o espaço urbano de São José dos Campos. 
Essa lei dividiu a cidade em Zona Urbana, Suburbana e Rural. As Zonas Urbana e Suburbana subdividiam-se, por sua vez, em zonas comerciais, industriais, residenciais, sanatorial e aeronáutica, as quais possuíam recuos e afastamentos diferenciados entre elas.

No capítulo da Lei Municipal $\mathrm{n}^{\mathrm{0}}$ 381, denominado Dos Arruamentos, por exemplo, são colocadas diretrizes para abertura de novas vias no município, quando esta tratou da questão e da permissão de loteamentos na Zona Rural e Suburbana que isentava o empreendedor de algumas exigências, com a finalidade de favorecer as habitações populares.

Analisando esta lei verificamos que, além das questões hoje inerentes aos códigos de edificações (dimensões e áreas mínimas de compartimentos, quesitos de insolação, ventilação e iluminação, requisitos construtivos, forma das licenças, etc.), esta apresentou questões relativas ao parcelamento, uso e ocupação do solo, atualmente tratadas de forma separada ${ }^{53}$.

Nesse sentido, podemos considerar que essa lei foi precursora, a primeira que continha diretrizes, pelo menos genéricas, para uso e ocupação do solo de São José dos Campos.

\subsubsection{O Plano CEPEU - USP}

O primeiro Plano Diretor de São José dos Campos teve início em abril de 1958, após a assinatura de um convênio entre a Secretaria de Viação e Obras Públicas do Estado de São Paulo, o Centro de Pesquisa e Estudos Urbanísticos - CEPEU Faculdade de Arquitetura e Urbanismo da Universidade de São Paulo e a Prefeitura Municipal, chefiada pelo então Prefeito Elmano Ferreira Veloso.

\footnotetext{
${ }^{53}$ Surgido em fins do século XIX, na Alemanha, o zoneamento atinge sua maturidade disciplinar no período pós Primeira Guerra e, a partir dai, se expande para quase todos os países. Sua primeira e mais significativa exportação foi para os Estados Unidos onde, após a adoção da primeira lei abrangente ao conjunto da cidade, em 1916, em Nova York, adquire características particulares. (FELDMAN, 1996).
} 
Inicialmente, o CEPEU elaborou planos para estâncias hidrominerais em função de um decreto do então governador de São Paulo, Jânio Quadros ${ }^{54}$. De acordo com esse decreto, as dotações orçamentárias para estâncias hidrominerais ficariam condicionadas às discriminações contidas nos Planos Diretores. Para tanto, foi firmado um convênio entre o governo do Estado, por meio do Departamento de Obras Sanitárias da Secretaria da Viação - DOS, o CEPEU e as prefeituras.

O CEPEU tinha a responsabilidade técnica, o DOS tinha a responsabilidade financeira e a prefeitura deveria contratar um arquiteto ou um engenheiro, especialmente para elaboração dos planos, desde que ele não participasse das atividades de rotina da administração.

Em São José dos Campos, a iniciativa para estabelecimento deste convênio coube ao CEPEU, que tinha como responsabilidade a orientação técnica para os trabalhos. Coube ao Departamento de Obras da Secretaria de Viação e Obras Públicas do Estado de São Paulo o encargo financeiro dos estudos que seriam desenvolvidos. Para a prefeitura, coube a contratação de um arquiteto para elaboração dos trabalhos e do Plano Diretor.

Em meados de 1958, foram instaladas as Comissões Técnicas ${ }^{55}$ e do Plano ${ }^{56}$, sendo iniciada a pesquisa pela equipe do CEPEU. Ao mesmo tempo foi realizada uma intensa propaganda do planejamento territorial, por meio de palestras e conferências, publicações em jornais e palestras na rádio de São José dos Campos. No Brasil, este foi

\footnotetext{
${ }^{54}$ Decreto Estadual $\mathrm{n}^{\circ} 23.399$.

${ }^{55}$ Para Anhaia Melo, aos técnicos, no âmbito da administração municipal caberia a elaboração das leis, que viabilizassem a concretização das aspirações populares e as diretrizes gerais (Anhaia Melo, 1929a In: Feldman, 2005 p. 59).

${ }^{56}$ Nas palestras proferidas por Anhaia Melo, em 1928, este defendia a Comissão do Plano da Cidade como dispositivo de administração diretamente ligado ao prefeito, livre das mudanças político-administrativas. Seguindo o modelo americano, a Comissão do Plano deveria, segundo Anhaia Melo (1928a, p. 284), ser instituída por lei, ter funções determinadas, ser de audiência obrigatória e atuar num nível superior ao das administrações que são transitórias acima das opiniões de momento: deve ser "vestal incumbida de zelar pelo fogo sagrado do desenvolvimento da cidade". Defende, ainda, que a Comissão do Plano deve ser constituída por representantes da sociedade para elaborar o plano da cidade e garantir a continuidade de sua orientação: é o fator de permanência.
} 
o período da ideologia desenvolvimentista que caracterizou o governo do Presidente Juscelino Kubitschek; estava sendo construída Brasília e planejamento era sinônimo de modernização.

A oficialização da Comissão do Plano Diretor se deu por meio do Decreto $\mathrm{n}^{\circ}$ 246, de 10 de setembro de 1958 e, nesse mesmo ano, também foi elaborado o Código de Edificações de São José dos Campos moldado na Lei no 5.261 do Município de São Paulo, elaborado pelo escritório técnico local e aprovado pela Câmara Municipal em 1959, com o objetivo de ser uma lei disciplinadora das construções no município. Nesse período deu-se início a elaboração do Plano Preliminar.

O Plano Preliminar teve como objetivo inicial preparar um Plano Piloto que visava: a) coibir os abusos de especuladores imobiliários; b) ordenar o uso do solo urbano; c) limitar as áreas passíveis de serem loteadas e d) reestruturar o sistema viário por meio de propostas de alterações e melhoramentos viários.

Em relação aos abusos da especulação imobiliária, estes tinham sido alertados pela imprensa local que, em matéria publicada em 1948, colocava que os terrenos comercializados em São José dos Campos eram caros e não possuíam nenhuma benfeitoria pública. Quanto à ordenação do uso do solo e da ocupação do solo, uma primeira tentativa de divisão do território foi elaborada por meio do Código de Obras de 1954.

Apesar de o Plano Piloto trazer esses objetivos primeiros, observou, numa abordagem preliminar, a necessidade de desenvolver estudos para elaboração de diretrizes quanto à questão do planejamento regional ${ }^{57}$. Esse estudo mostrou como maior dificuldade o fato de não existir, naquele período, no Estado de São Paulo, um sistema de planejamento de suas diversas regiões.

\footnotetext{
${ }^{57}$ A divisão em regiões e sub-regiões do Estado de São Paulo adotada no trabalho de elaboração do Plano Preliminar é a "Proposta definitiva" elaborada por Economia e Humanismo, publicada no trabalho Comissão Interestadual da Bacia Paraná - Uruguai - Problemas de desenvolvimento necessidades e possibilidades do Estado de São Paulo. Vol.II SAGMACS: São Paulo, 1954. 2 volumes, p. 134.
} 
Após estudos e levantamentos da região, o CEPEU recomendou a criação de um sistema de Planejamento no Vale do Paraíba para que esse pudesse estudar e propor soluções conjuntas para os municípios. Essa diretriz resultou, quando da elaboração dos Planos Setoriais (1961-1964), na proposta de minuta de um convênio entre os municípios do Vale do Paraíba que visava seu desenvolvimento econômico.

Esse consórcio abordou a necessidade de elaborar um plano regional com a indispensável participação dos governos estadual e federal: para a execução das obras e serviços de interesse regional; para a organização da estrutura administrativa e para conseguir os recursos mínimos e necessários para seu funcionamento.

Com a adoção desse convênio acreditava-se que, a partir de uma estrutura simples, poderiam ser executados obras e serviços de interesses comuns, mediante a criação de autarquias ou a contratação direta de empresas especializadas.

De acordo com o resumo de trabalhos do Plano Preliminar, datado de 1964, também foi possível organizar os cadastros locais e, desta forma, a equipe ganhou tempo para realizar uma pesquisa e um estudo mais prolongado e aprofundado que iria permitir um melhor amadurecimento e propor soluções para aos problemas constatados no diagnóstico preliminar.

A partir desses fatores identificados e que tiveram um resultado favorável para a conjuntura do planejamento, permitiram o amadurecimento da experiência do Centro de Pesquisa e Estudos Urbanísticos.

A possibilidade de uma ação mais ponderada e integral e, ao mesmo tempo, que as novas edificações e os novos loteamentos, então controlados por decretos e leis rigorosos, foram aceitas pela população de São José dos Campos. 
Conforme o resumo desse relatório:

No início da elaboração do Plano Preliminar foram realizadas várias reuniões e debates com as comissões de São José dos Campos e, do diálogo entre técnicos e representantes da comunidade, foram verificadas três falhas quanto à forma pela qual deveriam ser efetuadas as pesquisas para o planejamento dos municípios. (Plano Preliminar 1964).

Em primeiro lugar, concluiu-se que as análises feitas por engenheiros e arquitetos sobre problemas de ordem geográfica, econômica, social, jurídica e outras, dificilmente poderiam ter a profundidade que o planejamento integral do desenvolvimento de um município requer.

Em segundo lugar, constatou-se que os levantamentos feitos de acordo com os métodos até então adotados tinham uma utilidade apenas imediata para o planejamento. Setores administrativos das prefeituras, caracteristicamente destinados a levantamentos e pesquisas, como por exemplo, o serviço de cadastro municipal, permanecia desorganizado e desatualizado. A organização desses setores é essencial para que se possa dar continuidade ao processo de planejamento, principalmente na preparação de orçamentos e de Planos Executivos.

$\mathrm{Na}$ conclusão dos trabalhos tornou-se evidente que: as pesquisas não deveriam ser feitas por equipes isoladas, cujas conclusões eram apresentadas aos planejadores por meio de gráficos e relatórios, uma vez que este tipo de transmissão de conhecimento da realidade municipal mostrou-se precário e os planos até então traçados poucos utilizaram tais informações.

Após o reconhecimento dessas três dificuldades enfrentadas pelos formuladores do Plano é que se modificou seu processo de elaboração para o planejamento de São José dos Campos nos seguintes aspectos:

1) providenciou-se o levantamento cadastral de imóveis e de equipamentos do município, entrosando-o, ao mesmo tempo, com o sistema de aprovação e fiscalização de obras da administração local; 
2) procurou-se disciplinar certos aspectos do desenvolvimento municipal por meio de decretos ou mesmo de leis municipais sobre loteamentos, zoneamento e outros problemas que necessitassem de soluções urgentes;

3) passou-se ao exame mais profundo de alguns aspectos e ao estudo de outros ainda não abordados, mediante a colaboração efetiva de cientistas sociais e de técnicos de outros setores.

A partir da nova consciência do problema de metodologia, os organizadores do Plano Preliminar conseguiram economizar uma despesa que seria feita num levantamento de dados superficiais e quase que inconseqüentes. Essa mudança teve de Bierkholz (1964) o seguinte comentário durante a elaboração do resumo dos trabalhos programados de 1964: "o planejamento de São José dos Campos marcou uma nova experiência nos métodos de trabalho do CEPEU: realização de estudos e pesquisas por meio de equipe polivalente, com profissionais especializados nos diversos ramos de conhecimento necessários ao planejamento".

Após essa constatação, passou a ser realizado um estudo em maior profundidade dos problemas econômicos e sociais da cidade, graças à participação de técnicos especializados. Foi abandonado o método, até então adotado, de realizar, preliminarmente, uma pesquisa geral que englobasse todos os campos, utilizando unicamente arquitetos. Tal metodologia foi aplicada nos demais planos que esse centro de estudos viria a fazer nas demais cidades do Estado de São Paulo.

Um outro conhecimento adquirido pelos formuladores do Plano Preliminar de São José dos Campos e que o resumo de trabalhos do Plano Preliminar (1964) apresentou-nos é que, nesse primeiro estudo, foi também possível organizar os cadastros locais da prefeitura desta cidade. A conseqüência da organização fez com que os técnicos ganhassem tempo para realização de uma pesquisa e que fosse realizado 
um estudo mais aprofundado que permitiu um melhor amadurecimento para propostas e soluções mais adequadas aos problemas levantados nos diagnósticos.

Essas constatações tiveram um resultado favorável de maneira geral, pois permitiram que o amadurecimento da experiência do Centro de Pesquisa e Estudos Urbanísticos possibilitasse uma ação mais ponderada e integral.

Depois de sanadas as dificuldades quanto ao levantamento dos dados socioeconômicos e da metodologia a ser aplicada para a formulação do Plano Preliminar, procedeu-se à elaboração de uma proposta para um zoneamento de massas, cuja diretriz tratava da etapa inicial de um estudo maior e mais detalhado para a elaboração futura de um zoneamento específico para cada bairro do município.

Para tanto, foi elaborado um primeiro estudo que adotou como base fatores: a) de ordem geográfica e climática: relevo, topografia, direção de ventos predominantes, abastecimento de águas e b) que envolviam os aspectos econômicos, sociais e políticos: a facilidade de comunicação viária entre os bairros, a distribuição equilibrada das zonas, a localização atual das indústrias e, principalmente, a necessidade de se encontrar um ponto de equilíbrio entre as conclusões técnicas e os anseios da população local.

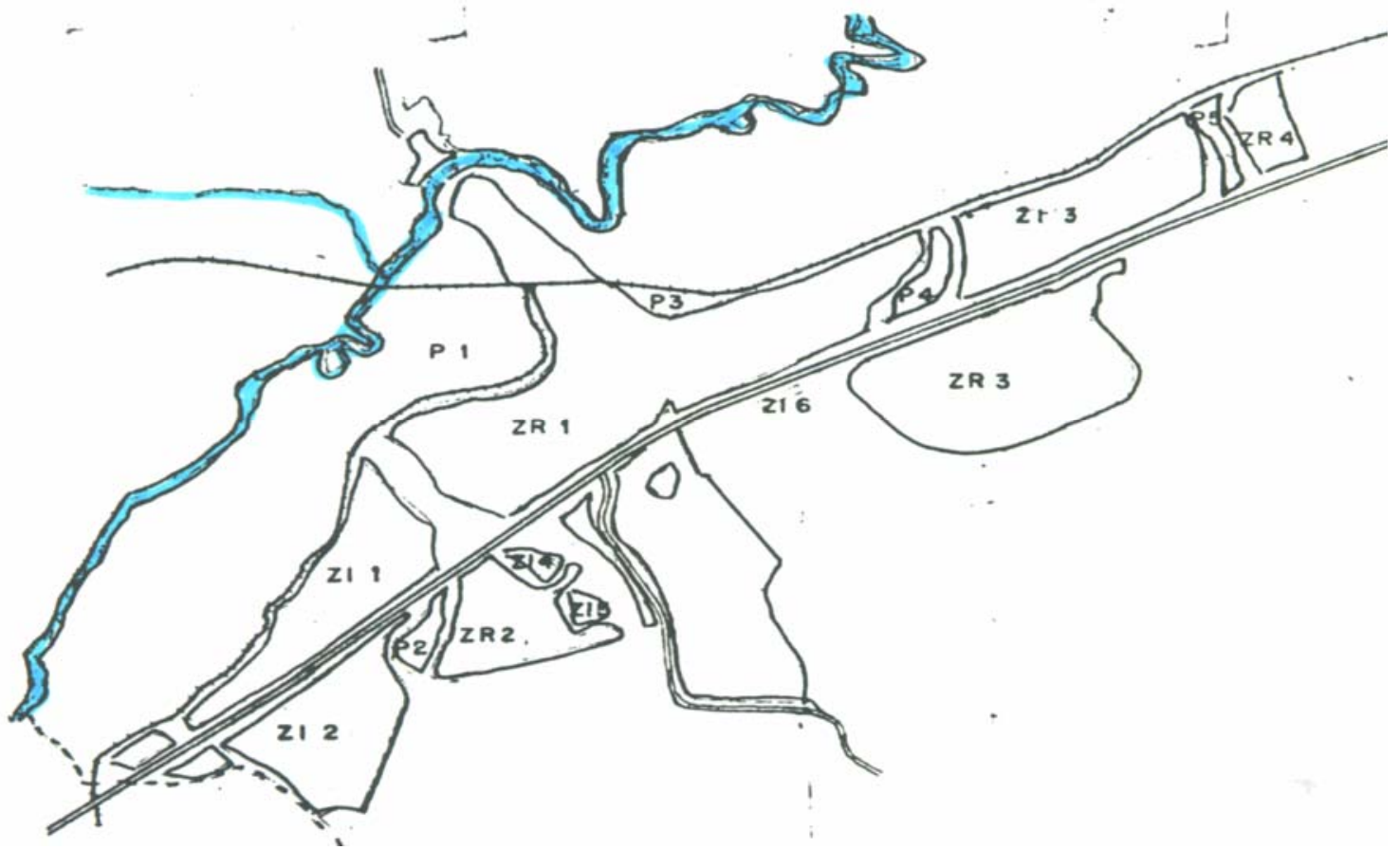

Figura 3.2 - Mapa das zonas residenciais.

Fonte: Plano Diretor Preliminar de SJC, 1961 
Ao analisarmos o mapa de zoneamento de massas proposto no Plano Preliminar, Fig. 3.2, verificamos que São José dos Campos foi dividida em zonas residenciais e industriais, em setores e unidades de vizinhança.

De acordo com os formuladores desse plano, esta proposta foi fundamentada no princípio de que as cidades, de um modo geral, deveriam ser planejadas como organismos polinucleados, ou seja, uma cidade com diversos centros e subcentros urbanos e com uma maior racionalidade na distribuição dos equipamentos sociais nos bairros que proporcionaria aos seus habitantes uma melhor qualidade de vida.

Continuando a análise do mapa da figura 3.2, também pudemos observar que a divisão das Zonas Residenciais visava a descentralização administrativa. Para tanto, foi prevista uma Zona Central denominada metropolitana que se destinava, exclusivamente, ao comércio e às funções administrativas.

A figura 3.2 mostra que uma outra diretriz se destacava em relação à zona denominada ZR-1 que se destinava, exclusivamente, ao uso residencial e foi subdividida em três distritos (Norte, Leste e Oeste), para fins de realização de obras e serviços. Observamos também que as zonas ZR-2 (Sul) e a ZR-3 (Leste) transpunham a Via Dutra.

De acordo com o Plano Preliminar, os quatro setores residenciais deveriam se transformar, após sua regulamentação, em distritos de obras que objetivavam a descentralização administrativa. Propunham ainda que, no centro dessas zonas, fossem reservadas áreas para escolas, comércio distrital e outros equipamentos comunitários.

Verificamos que as zonas residenciais propostas eram, na maior parte, desabitadas e foram destinadas à expansão dos setores residenciais. Compreendiam cerca de 50\% da Zona Residencial total prevista no Plano Preliminar.

Outro aspecto observado foi quanto à divisão da Zona Urbana e a da expansão urbana em setores, bem como a divisão do núcleo urbanizado em unidades de vizinhança, resultado de estudos que tiveram como objetivo principal o planejamento de 
um sistema viário regional integrado e que não trouxesse conflitos na estrutura viária do município.

Com o objetivo de atender as diretrizes viárias, foi projetado um sistema principal que estabelecia uma ligação mais rápida ao centro urbano e procurava dividir a zona de expansão urbana em unidades de vizinhança, possibilitando o planejamento de centros comerciais, escolas, parques e instituições de interesse social para cada unidade.

Em relação aos aspectos sociais abordados no Plano Preliminar de São José dos Campos, foi constatado que havia grande carência de seus habitantes em função do fluxo de pessoas (origens, procedências, situações econômicas e sociais diferentes) que se estabeleciam na cidade por causa das oportunidades criadas pelo desenvolvimento industrial, tal como a implantação da empresa francesa RHODIA e as conseqüências da migração para o município. Este fato foi reforçado quando a GM do Brasil se instalou em São José dos Campos em 1957.

Em relação à educação, o Plano Preliminar apresentou como um dos problemas mais graves a falta de recursos com que se defrontavam os responsáveis pelas escolas públicas. Após levantamentos e estudos para elaboração de um cálculo de demandas do município, constatou-se que cerca de 38\% das crianças de São José dos Campos estavam fora da escola. Em função disso, foi recomendada a elaboração de um Plano Educacional que deveria fornecer dados cientificamente válidos para a avaliação do déficit escolar e para a correta localização das unidades a serem construídas.

Outro dado importante apresentado pelo diagnóstico do Plano Preliminar foi que este elaborou um extenso levantamento com relação à análise financeira da prefeitura, com o objetivo de sugerir medidas que viessem a tornar o setor financeiro o mais funcional possível, proporcionando, assim, os recursos para a execução do Plano Diretor de Desenvolvimento Integrado. 
As principais deficiências diagnosticadas foram:

a) falta de flexibilidade para atualização, devido à conjuntura fortemente inflacionária que exigia contínuos reajustes;

b) falta de conceituação dos preços, não havendo a vantagem decorrente de uma rápida atualização dos seus valores pelo próprio executivo;

c) inexistência da Contribuição de Melhoria para o financiamento de obras públicas que ocasionam valorização do imóvel

d) a não utilização presente de empréstimos consolidados, isto é, de longo prazo.

As principais medidas sugeridas foram:

a) reorganização geral do setor tributário da prefeitura, principalmente, a organização do cadastro imobiliário e de um novo código tributário;

b) atualização dos valores das taxas, mantendo-as em dia, revendo-se também o critério de sua apuração;

c) caracterização de preços a partir daqueles que são havidos com taxas, possibilitando a atualização mais rápida dos valores (tarifas), por meio de ato do poder executivo;

d) utilização da contribuição de melhoria, que poderia constar no código tributário, e que resolveria o problema do financiamento das obras em que houvesse valorização da propriedade dos contribuintes beneficiados (artigo 30 da Constituição Federal);

e) ativação dos trabalhos para obtenção de empréstimos a longo, ou mesmo em médio, prazo, para financiar as obras programadas.

Como solução para essas constatações foi recomendado pelos formuladores do Plano Preliminar que fossem feitos empréstimo na Caixa Econômica Estadual. Em 1961 foi entregue o Plano Preliminar para São José dos Campos, um instrumento que tinha como objetivo principal: combater e coibir a especulação imobiliária, limitando áreas 
loteáveis, ordenando sumariamente os vários usos do solo urbano e reestruturando o sistema viário.

Concluído o Plano Preliminar, em 1961, foram realizados vários Planos Setoriais, no período de 1961-1964. Dentre eles destacamos os seguintes trabalhos: a) proposta de um zoneamento industrial; b) plano urbanístico para a área central; c) plano geral de trânsito; d) estudos para a erradicação das favelas da linha velha ${ }^{58}$ e e) programa administrativo.

A proposta de um zoneamento industrial teve como maior preocupação os distúrbios que a implantação de uma indústria, sem diretrizes, poderia vir a causar à sua vizinhança. Utilizando esse critério, as áreas industriais foram subdivididas em indústrias leves; indústrias incômodas e indústrias nocivas e perigosas. A partir desta classificação foram determinadas áreas na cidade para implantação dos três tipos de indústrias, assim denominadas: ZI1, ZI2 e ZI3. (ver Figura 3.2 com a proposta para um Zoneamento de Massas).

As áreas para indústrias leves seriam indicadas em função de estudos de cada bairro. Foram reservadas, ao longo de todo o trecho da Rodovia Dutra, áreas destinadas às indústrias incômodas ${ }^{59}$.

Em relação ao plano urbanístico para a área central (Zona Metropolitana) foram estabelecidas diretrizes para os usos comerciais e incentivos à construção de edifícios destinados ao comércio e serviços. Não identificamos diretrizes para qualquer estímulo a residências nessa área.

\footnotetext{
${ }^{58}$ Segundo o Plano Preliminar, o programa desfavelamento nasceu espontaneamente da comunidade, cujas manifestações se deram por meio de reuniões, de artigos em jornais e de um ciclo de palestras.

59 Por meio do Decreto Municipal $n^{\circ}$ 250/58, procurou-se preservar a zona habitacional de eventual poluição das indústrias. Outro objetivo observado foi o de proteger a captação de água para o consumo da população.
} 
Também foram estabelecidos limites de volume e população em relação ao tamanho dos lotes, quotas de áreas livres no solo e gabarito de altura dos edifícios, medidas que tiveram como princípio preservar uma boa qualidade de vida aos usuários do centro quanto à insolação e paisagem.

Com referência ao plano geral de trânsito, seu objetivo era planejar um sistema de vias principais urbanas a fim de se estabelecer comunicação rápida entre o centro da cidade e bairros e entre os próprios bairros, conforme podemos observar na Figura 3.3 a seguir.

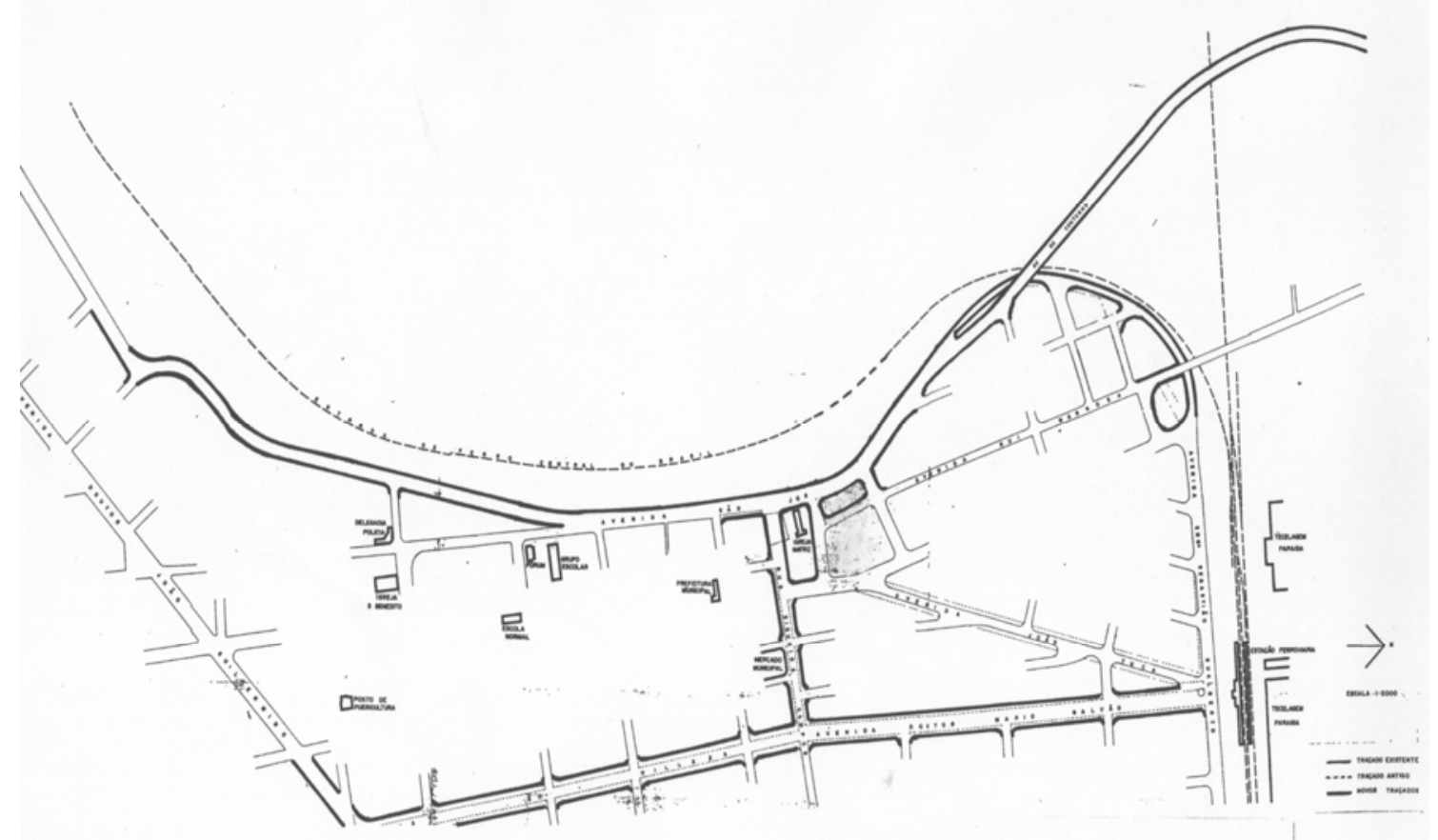

Figura 3.3 - Proposta de alargamento viário para a área central Fonte: Plano Diretor do Município de São José dos Campos, 1964

Nessa proposta foram apresentados desvios dos trechos rodoviários que cortavam a cidade com a finalidade de canalizar o tráfego regional de passagem por áreas exteriores ao Centro. Também foi estudada a localização do Centro Cívico e da Estação Rodoviária. Procurou-se ainda, proteger os fundos de vales com avenidasparque, garantido a drenagem natural para o esgoto e águas fluviais, com intuito de beneficiar a necessidade de desapropriações onerosas de imóveis. 
Em relação ao estudo para erradicação da favela da Linha Velha ${ }^{60}$, foi constado que para a execução desse programa seriam necessários um plano de cadastramento das famílias, ações para contenção de seu crescimento, programa de instrução educativa de base aos favelados, divulgação do projeto, programa de obtenção de fundos, construção e reembolso de casas, quadro técnico e administrativo e a relação das tarefas a serem executadas. A remoção da favela deveria dar lugar à construção de uma grande avenida estrutural ao longo do antigo leito da antiga ferrovia (parte do projeto do Anel Viário) e a construção do Paço Municipal que viria a se concretizar em 1979.

Durante o período de elaboração dos Planos Setoriais, em 1962, a pedido do Prefeito José Marcondes Pereira, o CEPEU organizou uma proposta de Programa Administrativo que se integrava nas propostas do Plano Preliminar. Este programa constituiu-se no primeiro plano executivo realizado pelo CEPEU, que continha as seguintes diretrizes e metas: a) reorganização e término do cadastro imobiliário; b) implantação completa da reforma administrativa proposta e aprovada; c) instalação e aparelhamento definitivo do Escritório Técnico de Planejamento; d) implantação imediata do projeto de trânsito já aprovado; e) abertura de vias públicas, de acordo com as prioridades indicadas; f) pavimentação das vias públicas, de acordo com o cronograma apresentado; g) execução das obras indicadas para ampliação do serviço de águas; h) execução dos projetos de esgoto, em conformidade com as prioridades indicadas; i) implantação das medidas propostas para organização do abastecimento da cidade e j) execução do plano proposto.

Com essas propostas, esperava-se que, em um ou dois anos, fosse implantada uma mentalidade de planejamento completamente enraizada e aceita por parte da administração e da população de São José dos Campos.

\footnotetext{
${ }^{60} \mathrm{O}$ aglomerado denominado Linha Velha situava-se no trecho, próximo à Região Central, onde anteriormente corriam os trilhos da EFCB, às margens do Córrego dos Lavapés. Esse ficou abandonado depois da transferência da linha férrea e passou a ser ocupado por uma população de baixa renda. Essa favela ocupa esse trecho até os dias de hoje, alguns projetos de reurbanização (revitalização) foram implantados nesse núcleo e seus moradores resistem sua permanência pelo fato de estarem próximos da Região Central.
} 
Em 1964, a Comissão do Plano Diretor foi transformada em um Conselho de Desenvolvimento que prestava assessoria técnica. Desta forma, concretizou-se todas as conclusões e metas do Plano Geral de Desenvolvimento para o município, plano que serviria como diretriz para o Poder Executivo e Legislativo orientarem o desenvolvimento municipal.

Naquele momento, também surgiu a proposta de criação de um órgão de planejamento, ligado diretamente ao prefeito municipal, com a denominação Escritório Técnico de Planejamento, com as atribuições principais de elaborar o Plano Diretor do Município e atualizá-lo constantemente, preparar os planos setoriais e, em seguida, preparar os planos executivos das obras a serem realizadas no município e coordenar sua implantação. Assim, esse escritório deveria, em função do próprio Plano, estabelecer as prioridades das obras e escaloná-las em função dos meios existentes, organizando o Plano Executivo para todo o período destinado à administração de um prefeito.

Uma das funções mais importantes do escritório do Plano, portanto, era manter a continuidade administrativa, dentro da descontinuidade política das administrações municipais. Este órgão de planejamento submeteria suas sugestões ao prefeito municipal que, as aprovando, ordenaria sua execução aos órgãos executivos da prefeitura.

O organograma do Escritório Técnico de Planejamento previa a criação de três setores:

1) Pesquisas, Estudos e Estatística. Os estudos seriam permanentes para orientação de uma política de acordo com as necessidades dos outros setores do Escritório Técnico ou dos demais órgãos da prefeitura;

2) Planejamento. Os técnicos do Setor de Planejamento teriam a seu cargo a elaboração dos Planos, tendo em vista os elementos fornecidos pelo Setor de Pesquisas, Estudos e Estatísticas, das diretrizes fixadas e de outros elementos obtidos; 
3) Programação, Coordenação e Controle da Implantação do Plano Diretor. Este Setor exerceria as funções citadas na sua designação e tratadas no item anterior.

4) Fez parte do organograma do Escritório Técnico de Planejamento a inclusão de uma Assessoria Técnica, integrada por consultores de diversas especialidades, os quais seriam solicitados pelo escritório, na medida das necessidades. A Comissão do Plano Diretor, constituída por elementos de entidades representativas da cidade, deveria exprimir a tendência e as aspirações da comunidade. Foram, ainda, previstas duas comissões de recursos: a primeira de Recursos do Zoneamento, para relatar as reclamações nas decisões do Escritório Técnico de Planejamento, na parte de zoneamento, e a segunda de Recursos Tributários, para pronunciar sobre recursos relativos aos lançamentos de tributos pela prefeitura. No entanto, este órgão técnico de planejamento previsto como um dos pilares para dar continuidade ao processo de planejamento, não foi implantado.

A seguir apresentamos a Fig. 3.4 com o organograma proposto no Plano Diretor de 1961. 


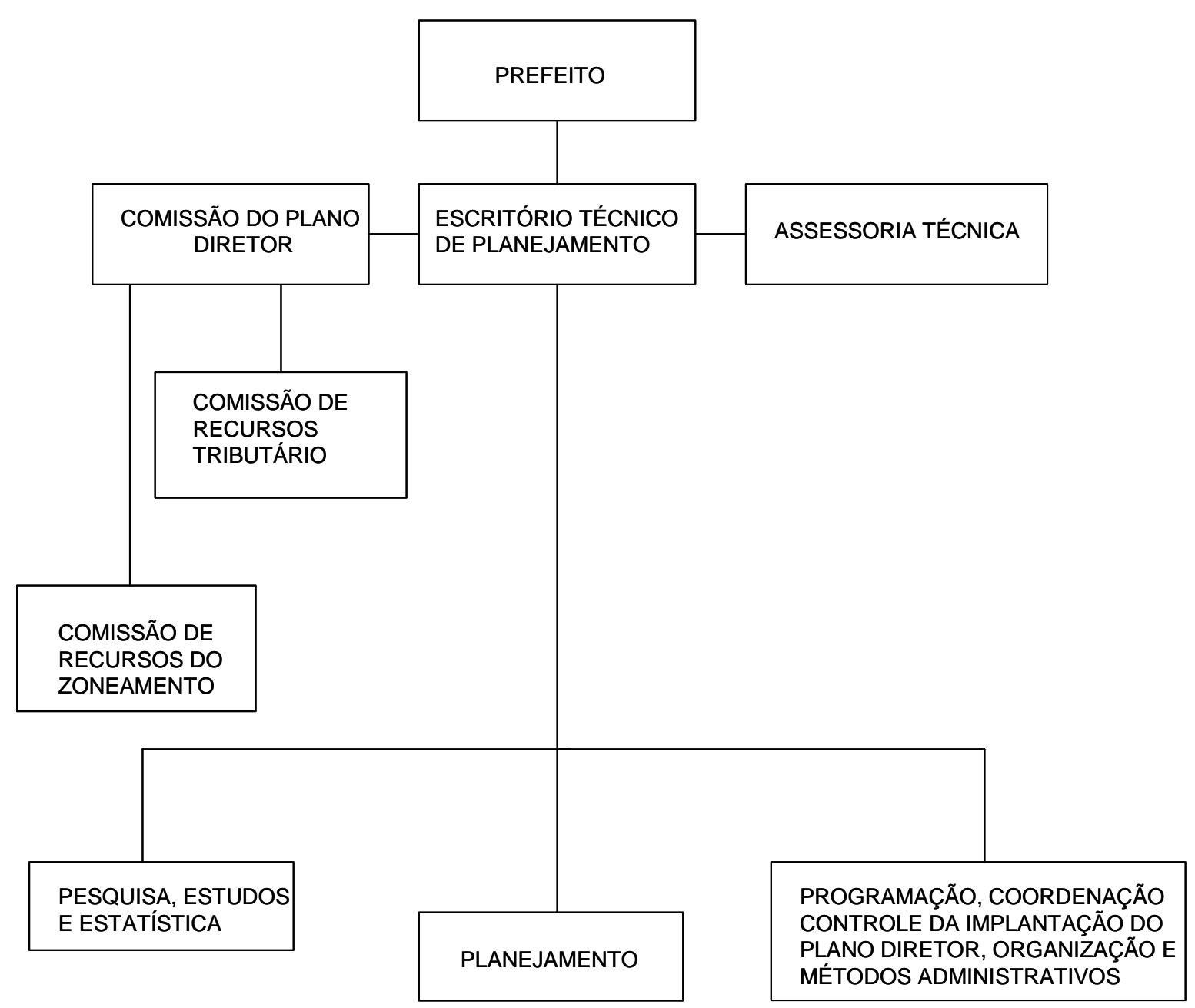

Figura 3.4 Organograma do Escritório Técnico de Planejamento Fonte: PDDI, PMSJC, 1964.

\subsubsection{Análise do Plano CEPEU - USP}

O Plano Preliminar e os Plano Setoriais elaborados pelo CEPEU-USP, no período entre 1958 a 1964, são compostos por 21 programas e projetos. Após analisarmos seu conteúdo, pudemos verificar que 35\% dos projetos previstos foram executados, $15 \%$ foram parcialmente executados e $50 \%$ não executados.

Em relação aos programas executados do Plano Preliminar, destacamos a regulamentação do perímetro urbano, o zoneamento de massas e as diretrizes para implementação de loteamentos. 
Sobre os programas executados dos Planos Setoriais, destacamos o desfavelamento da Linha Velha ${ }^{61}$, a organização do cadastro imobiliário, a elaboração do Plano Setorial de Saneamento e a construção de uma lagoa de oxidação para tratamento de esgoto, a primeira do país, conforme preconizado no Plano Preliminar. Como resultado desse plano, em 1968, a prefeitura contratou uma empresa especializada e concluiu o novo Plano de Abastecimento e Distribuição de Água e Coleta de Esgotos para a cidade, atendendo às diretrizes do PDDI.

Quanto aos projetos parcialmente executados, destacamos o Plano Geral de Trânsito, implantado apenas uma parte da proposta apresentada, que não atingiu seu objetivo maior que era o de proporcionar uma integração entre os bairros e a Região Central. No entanto, esse Plano utilizou como instrumento a adoção de faixas non aedificandi nas principais ruas e avenidas de São José dos Campos. Essa diretriz possibilitou a implantação das vias projetadas e futuros alargamentos das vias existentes.

Embora o Plano tenha efetuado a organização do Cadastro Imobiliário, os projetos para revisão da planta genérica de valores e a atualização dos valores das taxas foram parcialmente executados e o Código Tributário, proposto pelos seus formuladores, o que também não foi implantado.

Outros sete projetos propostos no Plano Preliminar e nos Planos Setoriais não foram executados: 1) descentralização administrativa; 2) Zona Metropolitana; 3) Zoneamento Industrial; 4) Código de Obras; 5) Fundo Municipal de Habitação ${ }^{62}$; 6)

\footnotetext{
${ }^{61}$ Para a execução deste Programa, o PDDI apresenta, com detalhes, todos os procedimentos, desde o plano de cadastramento das famílias; ações para contenção de seu crescimento; programa de instrução educativa de base aos favelados; divulgação do Projeto, programa de obtenção de fundos; construção e reembolso de casas; quadro técnico e administrativo necessários e a relação das tarefas a serem executadas.

${ }^{62}$ Objetivando a participação municipal no problema da habitação popular, foi proposta a constituição do Fundo Municipal de Habitação, através da destinação de parte da arrecadação municipal, relativa ao imposto de transmissão "inter vivos" e de parcela igual a ser aplicada pela Caixa Econômica Estadual.
} 
Planejamento físico das áreas habitacionais ${ }^{63}$ e 7) criação do Escritório Técnico de Planejamento (gestão do plano).

Diante dessas constatações, podemos verificar que alguns fatores, além dos projetos não implantados, foram responsáveis para que o Plano Preliminar e os Planos Setoriais não fossem implantados: 1) Esses planos não foram aprovados através de lei ou decreto; 2) O Escritório Técnico de Planejamento destinado à gestão do Plano também não foi regulamentado e 3) Descompatibilidade entre os Planos Setoriais e a Administração Pública.

Em relação à descompatibilidade constatada, verificamos que não havia uma estimativa dos custos para execução dos programas e projetos contidos nesses planos. Não havia também uma formulação de estratégias e diretrizes para a área habitacional que se restringiu ao desfavelamento da Linha Velha e para a indicação de se utilizar os empréstimos da Caixa Econômica Federal para que essa promovesse recursos para a construção e financiamento para a casa própria.

Destacamos que, nas áreas de Educação e Saúde, o Plano Preliminar apresenta a sugestão de ser elaborado um plano específico para cada uma dessas áreas. No entanto, de acordo com o Arquiteto Breno Cyrino Nogueira, dos trabalhos de Planejamento Setorial elaborados pelo CEPEU, após a conclusão do Plano Preliminar, os relacionados com os setores da Saúde e da Educação foram os que tiveram maior rendimento em termos de aplicação prática. Os motivos principais foram: 1) a própria natureza do planejamento da organização administrativa, em que está implícita a atuação imediata, quase que concomitante ao planejamento; 2) o natural interesse das administrações municipais e dos próprios municípios por este aspecto do planejamento, o

${ }^{63}$ Segundo relato do PDDI, este trabalho alcançou, apenas, o estágio de orientações das fases para este planejamento, em virtude da escassez de tempo, da insuficiência de dados cartográficos, da necessidade de levantamento de dados e da procura de soluções urbanísticas compatíveis com a realidade social e econômica da cidade.

As etapas indicadas para efetuar o Planejamento das áreas habitacionais foram: revisar o zoneamento de massa, estender a setorização para todas as áreas de expansão e elaborar o planejamento dos diversos setores habitacionais. 
que reverte em um efetivo apoio à atuação dos técnicos e 3) a experiência já acumulada pelos técnicos do CEPEU, que se responsabilizaram por este setor de planejamento, tornando desembaraçado o andamento dos trabalhos.

Ressaltamos que, tanto o Plano Preliminar, como os Planos Setoriais elaborados pelo CEPEU - USP, foram responsáveis: 1) Divulgação das idéias de planejamento que vinham sendo desenvolvidas naquele período; 2) Iniciação de um processo de planejamento na Prefeitura de São José dos Campos para formar uma equipe local qualificada e 3) A participação da sociedade que foi institucionalizada desde o início de sua elaboração pela Comissão do Plano.

Em 1964, o Plano Diretor elaborado pelo CEPEU - USP foi entregue.

Observamos que foi característica do PDDI de 1961 a busca de uma visão geral da realidade municipal que, através do conhecimento e compreensão dos aspectos econômico, social, físico-territorial e institucional foi elaborado um diagnóstico. No entanto, essa visão, apenas nos limites da técnica e dissociada dos conflitos de interesses, demonstraram que o PDDI, mesmo tendo sido um trabalho técnico de excelente qualidade, não foi suficiente para direcionar a postura da prefeitura em relação à gestão desse plano.

Ressaltamos ainda, que o PDDI de 1961 foi responsável pelo início do controle e ordenamento da expansão urbana do município, do disciplinamento do uso e ocupação do solo, demonstrando a prevalência da legislação de Parcelamento do Solo Urbano e do Zoneamento, diretrizes estas embasadas na caracterização do meio físico do município e nas questões ambientais voltadas para a proteção e a preservação do meio ambiente, a exemplo da reserva de faixa non aedificandi, ao longo dos fundos de vale, para criação de um sistema de park-way com o intuito de garantir a drenagem natural e a passagem de emissários de esgotos e águas pluviais. Além destas diretrizes ambientais foram também formuladas disposições em relação à proteção do Rio Paraíba do Sul que visava preservá-lo como manancial de abastecimento. 
No entanto, foi em relação à abordagem regional contida nesse Plano que devemos destacar que o Plano apontou como maior dificuldade encontrada por seus formuladores a inexistência no Estado de São Paulo, naquele período, de um sistema de planejamento de suas diversas regiões, de onde deveriam decorrer as diretrizes para os Planos Diretores Municipais. Esse plano sugeriu a criação de um convênio de consórcio entre os municípios do Vale do Paraíba, objetivando estudar e propor soluções para os problemas comuns.

Esta proposta certamente contribuiu para conscientizar os prefeitos do Vale do Paraíba sobre a importância do Planejamento Regional, o que provavelmente resultou, em 1970, na criação do Consórcio de Desenvolvimento do Vale do Paraíba (CODIVAP) e estes continuam a se reunir até os dias de hoje para tratar de assuntos relativos ao desenvolvimento da Região do Vale do Paraíba.

\subsubsection{O Plano Diretor SERETE S.A. (1969-1971)}

Os avanços registrados em relação às políticas urbanas estatais, no governo do General Castelo Branco, são aprofundados nos governos militares seguintes, no sentido da conformação de uma política nacional de desenvolvimento urbano.

Nesse mesmo ano, são criados o Serviço Federal de Habitação e Urbanismo (SERFHAU), que foi regulamentado em $1967^{64}$, e um Fundo de Financiamento de Planos de Desenvolvimento Local Integrado no Banco Nacional da Habitação (BNH), com a finalidade de financiar os planos de estudos de desenvolvimento integrado.

A criação do SERFHAU representou um passo decisivo para o projeto de introdução do planejamento como função de governo, à medida que responde ao princípio das funções de planejamento e estimula a elaboração de Planos Diretores, através de financiamentos, sendo esta a primeira manifestação institucionalizada e sistemática de ingerência do governo federal no planejamento municipal.

\footnotetext{
${ }^{64}$ Lei 4.380 de 21.8.1964 e Decreto 59.917 de 30.12.1966.
} 
Nesse período, o processo de urbanização das cidades brasileiras e, principalmente, no Vale do Paraíba vinha ocorrendo de forma muito intensa. O governo estadual e o federal buscaram, através dos Planos Diretores, equacionar a longo prazo os problemas das cidades.

Segundo justificativa do PDDI de 1971, a liberação de recursos ficaria condicionada à criação, pelas regiões e municipalidades, de órgãos permanentes de planejamento e desenvolvimento local, ao mesmo tempo em que se condicionava a liberação de recursos a uma estrutura de planejamento que contratava a elaboração dos planos e estudos ${ }^{65}$.

Com essa concessão de verbas para o planejamento e abertura para contratação externa de planos, os órgãos de planejamento se multiplicam, assim como os planos e as empresas de consultoria, que passaram a assumir a maioria dos planos elaborados nos anos 60 e 70, no país. Um dos objetivos dessa política baseava-se em estabelecer critérios de âmbito nacional para a execução dos programas habitacionais para a habitação de interesse social.

Ao contrário, a historiografia contemporânea sobre os planos diretores no Brasil tende a identificar que, nesse período, por meio da Lei $4.320 / 64$, da Lei Complementar $n^{\circ} 3 / 67$ e do Ato Complementar $n^{\circ} 43 / 69$, foi estabelecida a diretriz de que todos os municípios deveriam elaborar seus planos diretores de desenvolvimento integrado, sem os quais, nenhum recurso de ordem federal ou estadual seria concedido.

Segundo Villaça (1999, p.224), a Lei no 4.320/64 é estritamente orçamentária e rege a elaboração dos orçamentos públicos. Nada diz respeito a Plano Diretor ou PDLI. A Lei Complementar $n^{\circ} 3$ e o Ato Complementar $n^{\circ} 43$ tratam do Plano Nacional e dos Orçamentos Plurianuais de Investimentos e nada falam sobre Plano Diretor ou PDLI e muito menos sobre a necessidade da existência destes para a concessão de recursos federais ou estaduais. Segundo o autor, isso nunca existiu.

\footnotetext{
${ }^{65}$ Decreto 59.917 de 30.12.1966, artigos 23 e 27.
} 
Villaça (1999), argumenta que a única coisa do gênero que houve foi um dispositivo da Lei Orgânica dos Municípios do Estado de São Paulo - o Decreto - Lei Complementar Estadual $n^{0} 9$ de 31/12/69 - que, no artigo $1^{\circ}$ de suas disposições transitórias dizia:

(...) nenhum auxílio financeiro ou empréstimo será concedido pelo Estado ou Município que, até 31 de dezembro de 1971, não tiver seus programas de ação baseado em um PDDI ainda que simples, mas orientado para um gradativo aperfeiçoamento, comprovando que o Município iniciou um processo de planejamento permanente.

No final dos anos 60, escritórios de arquitetura se cadastraram como empresas de planejamento, como, por exemplo, o escritório Jorge Wilheim que veio a formular o Plano de Desenvolvimento Integrado de 1971 para o município de São José dos Campos. Naquele período, a inserção dos arquitetos no mercado de trabalho ligada à elaboração de planos se ampliou com a criação do SERFHAU.

Estas empresas realizavam Planos dos Municípios de maior porte, enquanto o Centro de Estudos e Pesquisas de Administração Municipal (CEPAM), criado em 1967, juntamente com consultores individuais, era responsável pelos Planos dos Municípios menores. (AZEVEDO, 1976 p.53).

De qualquer forma, os avanços registrados no que se refere às políticas urbanas estatais, no início do regime militar, são aprofundadas nos governos seguintes no sentido da conformação de uma política nacional de desenvolvimento urbano. Nesse contexto histórico foi elaborado o segundo Plano Diretor de Desenvolvimento Integrado de São José dos Campos que passaremos a explicitar.

O PDDI de 1971 teve início no ano de 1969 por meio da contratação da empresa Serete S.A. Engenharia pela prefeitura municipal, fazendo parte deste trabalho, como subcontratada, a SD Consultoria de Planejamento Ltda. e Jorge Wilheim Arquitetos Associados como responsável pelos aspectos urbanísticos. O Estudo Preliminar 
elaborado para o PDDI Serete S.A., apresentou os seguintes diagnósticos para São José dos Campos:

a) tende a aumentar as perspectivas como localização de atividades econômicas, sobretudo industriais;

b) é fácil inferir as vantagens decorrentes dessa situação, que propiciará ao município, proximidade com o Porto de São Sebastião, destinado a tornarse o grande porto de cargas a granel do Estado de São Paulo;

c) o município situa-se próximo aos maiores centros de consumo, de abastecimento de matérias-primas e de produção do país;

d) a ligação Campinas-Jacareí, em fase de construção, irá favorecer o município ${ }^{66}$.

No decorrer da elaboração do Estudo Preliminar pudemos verificar três aspectos sobre o desenvolvimento urbano que vinha ocorrendo em São José dos Campos.

O primeiro aspecto confirmava a tese de que a cidade tinha potencial industrial, processo esse que passou a ocorrer com mais intensidade a partir da década de 50, como apresentado no Capítulo 2.

O segundo dizia respeito às barreiras físicas naturais (a várzea do Banhado, o Rio Paraíba e os pequenos vales que cortam o município no sentido perpendicular à Rodovia Dutra) e artificiais (Rodovia Dutra, estrada de ferro, faixa de alta tensão da então Light, vazios urbanos e as áreas das grandes indústrias) que influenciaram o desenho do tecido urbano. O terceiro aspecto mostrava a potencialidade da cidade no sentido de vir a se tornar referência regional e teria o importante papel de liderar o desenvolvimento do Vale do Paraíba em vários setores.

Outra característica observada nesse Plano Preliminar foi a elaboração de um planejamento viário. Esse planejamento foi destinado a dar unidade e organicidade ao

\footnotetext{
${ }^{66}$ In Plano Diretor de Desenvolvimento Integrado, 1971.
} 
território urbano e teve como diretriz conduzir e induzir a ocupação do solo, proposta no Plano, que era conter a expansão horizontal. Observamos que o fenômeno migratório existente no município, teve influência significativa na sociedade, na medida em que alterou toda a composição da estrutura social local.

Assim como constatamos no Plano Preliminar elaborado pelo CEPEU - USP, e, naquele momento com maior intensidade, esse fenômeno vinha ocorrendo devido às inúmeras indústrias que estavam se instalando e pela necessidade de mão-de-obra que atraia para São José dos Campos um grande contingente populacional que, por sua vez, introduziu problemas novos para os serviços locais. A cidade passou de pequeno centro urbano para uma importante cidade industrial do Estado.

Naquele período, o crescimento demográfico do município era caracterizado pelo aumento da camada de nível de renda mais baixo que apresentava maiores problemas para os serviços públicos, obrigando o Estado e o município a assumirem o desempenho dos serviços urbanos.

A ocupação do solo vinha ocorrendo de forma desorganizada, pois as indústrias de pequeno e médio porte se instalavam no território, no interior da trama urbana, e as indústrias de grande porte eram implantavam ao longo da Rodovia Dutra deixando, entre elas, grandes vazios urbanos que interrompiam as estruturas viárias e acentuavam a descontinuidade da ocupação do solo.

Como pudemos observar, a evolução urbana nessa fase colocou a cidade diante de graves problemas: a) descontinuidade do tecido urbano; b) drenagem urbana e c) carência de pavimentação. Para diminuir os efeitos desses problemas, o plano propôs algumas estratégias de ocupação do solo que seriam implantadas em etapas.

Uma das principais estratégias adotadas pelo PDDI de 1971 foi estimular a ocupação de grandes vazios urbanos identificados naquele estudo e, como medida para dar suporte a essa diretriz principal, foi proposta a elaboração de uma lei de zoneamento que incentivasse a construção de edifícios para habitações coletivas e comerciais e 
conjuntos habitacionais em série e, principalmente, tivesse o papel de coibir a expansão horizontal.

As diretrizes urbanísticas propostas pelo PDDI de 1971 em relação ao uso e ocupação do solo indicavam que a diminuição dos custos de infra-estrutura se daria na medida que se concentrasse a densidade. Cabe ressaltar que o Plano Diretor de Desenvolvimento Integrado de 1971 para São José dos Campos não fez nenhuma referência às características do meio físico-territorial. Verificamos que não houve análise de sua potencialidade e das limitações, as quais não foram consideradas para definir as áreas que deveriam ser ocupadas com o crescimento urbano acelerado que ocorria naquele período.

O PDDI de 1971 destacou a necessidade de consolidar São José dos Campos como pólo econômico da região do Vale do Paraíba. Verificamos que todo o planejamento apresentado no plano foi pensado e elaborado para a cidade receber o desenvolvimento econômico, a industrialização e a modernização que era anunciada naquele período. Verificamos também que, as diretrizes urbanísticas desse plano, se sobressaíram sobre as demais áreas e o zoneamento proposto teve a função maior de reservar espaços para a implantação das grandes indústrias.

Com o objetivo de coordenar e garantir esse processo de planejamento, foi proposta a criação da Assessoria de Coordenação e Planejamento Municipal (ACEPLAM). Em 06 de janeiro de 1970, ainda na gestão do Prefeito Veloso, mesmo sem a conclusão final do PDDI, foi aprovada a Lei Municipal 1534, criando a ACEPLAM. Este órgão teve um caráter estritamente técnico, diretamente subordinado ao prefeito e composto por um Conselho de Desenvolvimento e uma Coordenadoria Executiva.

Em 04 de fevereiro de 1970 assume o governo municipal Sérgio Sobral de Oliveira e, em 03 de março do mesmo ano, o prefeito aprova e sanciona a nova Organização Administrativa da Prefeitura da Estância de São José dos Campos, revogando a Lei que criou a ACEPLAM. 
Além da ACEPLAM, o PDDI de 1971 recomendou a criação de uma sociedade de economia mista, com receita e estrutura próprias para executar os serviços de pavimentação, abertura de avenidas, construção de parques, viadutos e outras obras e serviços previstos no Plano, em função das dificuldades do aparelhamento administrativo.

Apontaram, entre outras, as seguintes razões: eficiência operacional, sujeição das relações de trabalho ao regime da legislação trabalhista, flexibilidade econômica, financeira e administrativa, minimização de problemas de caráter político.

Após a elaboração e entrega do PDDI à Prefeitura em 1970, alguns segmentos da sociedade começaram a se manifestar, sobretudo, engenheiros e arquitetos devido à falta de informações e discussões por parte da municipalidade.

As discussões em torno do PDDI praticamente cessaram, pois esse somente viria a ser promulgado em 30 de novembro de 1971, por meio da lei 1623, ao passo que a lei de zoneamento veio a ser sancionada em 13 de setembro de 1971 por meio da lei 1606. Nota-se, portanto que, diferentemente do que a lógica poderia sugerir, a lei de zoneamento acaba por se antecipar ao plano.

Assim as discussões, antes centradas no PDDI, passaram a focar a proposta apresentada pela prefeitura acerca da lei de zoneamento de 1971 que iremos tratar no item 3.5.

\subsubsection{A Lei de Parcelamento e a Lei de Zoneamento de $1970^{67}$}

O PDDI de 1971 propôs uma nova legislação de Parcelamento do Solo que estabeleceu os requisitos para a implantação de novos loteamentos e contemplava diretrizes urbanísticas, obras de infra-estrutura, normas para aprovação e o sistema de garantia para execução das obras por parte do loteador.

\footnotetext{
${ }^{67}$ Lei Municipal 1576/70 e Leis Municipais 1606/70 e 1617/70.
} 
A Legislação de Parcelamento foi aprovada em 15 de setembro de 1970, por meio da Lei Municipal 1576/70, e perdurou até 1980, quando foi aprovada nova lei dispondo sobre esta matéria.

Essa lei teve o objetivo principal de cumprir a política proposta no PDDI de 1971 que era a de não incentivar a expansão horizontal, à exceção dos vazios urbanos entre as áreas já urbanizadas. Quanto aos parcelamentos do solo, foram exigidas todas as obras de infra-estrutura, à exceção da pavimentação.

Para contenção da expansão horizontal foi proposta a associação a uma política de construção de conjuntos habitacionais para as classes de renda que se enquadravam nos critérios de financiamento do Sistema Financeiro da Habitação. Como conseqüência dessa diretriz podemos verificar os inúmeros conjuntos habitacionais implantados na Região Leste de São José dos Campos.

Com o objetivo de reforçar essas diretrizes, o zoneamento teve como maior preocupação a incumbência de garantir as zonas destinadas, exclusivamente, às indústrias. Acreditava-se que, com essa medida, a quantidade de empregos industriais seria aumentada e a escassez dos terrenos disponíveis, ao longo da Dutra, seria preservada, garantindo assim, que somente indústrias seriam implantadas e não loteamentos residenciais.

Em relação ao o uso e ocupação do solo, o PDDI apontou que, na maioria das cidades brasileiras, existia a preocupação de se preservar a zona residencial, normalmente objeto de reinvidicação das camadas sociais de maior renda. No caso de São José dos Campos, especificamente, verificou-se acentuada preocupação de se garantir prioritariamente a determinação de uma zona de uso estritamente industrial. Essa estratégia foi decorrente da necessidade de se incrementar o número de empregos industriais e a escassez de terrenos disponíveis ao longo dos eixos rodoviários.

Com referência à exclusividade no uso do solo, justificada pela estratégia geral, o restante dos usos deveriam variar pela predominância e não pela exclusividade. 
"O zoneamento de predominância foi a solução encontrada para racionalizar o uso do solo, sem, porém, torná-lo rígido a ponto de impedir que pequenas variações e imprevistos espontâneos ocorressem numa faixa de tolerância. Estes enriquecem os sistemas de vida urbanos" ( PDDI, 1970, p.39).

Sobre a exclusividade mencionada em relação à questão industrial, o zoneamento proposto teve o conceito de predominâncias como regra, como forma de racionalizar o uso do solo. A idéia era prover o município com um zoneamento não muito rígido e não impedir que pequenas variações e imprevistos espontâneos ocorressem numa faixa de tolerância.

Ao analisarmos a lei de zoneamento $n^{0}$ 1606/71, esta pareceu-nos simples, se comparadas às atuais leis de zoneamento, pois contava com 25 artigos.

O município de São José dos Campos foi dividido em três zonas de uso: urbano, de expansão urbana e rural. Os perímetros dessas zonas foram fixados por meio de lei, as zonas de uso foram inseridas na zona urbana e as de expansão urbana tiveram os seus perímetros delimitados por meio de ato do executivo e encaminhada à Câmara Municipal em junho de 1971.

Destacamos que a legislação de parcelamento do solo estabeleceu diretrizes urbanísticas para a implantação de loteamentos no município e as normas para sua aprovação eram claras com relação à infra-estrutura e um sistema de garantia para a execução das obras por parte do loteador.

Ressaltamos na lei de zoneamento: a) fixação do percentual mínimo de 35\% e máximo de 50\% para áreas públicas destinadas a equipamentos comunitários, sistema de lazer e circulação e b) inclusão de um dispositivo na legislação de que a prefeitura poderia aprovar projetos de arruamentos, loteamentos e desmembramentos para impedir o número excessivo de lotes e o conseqüente aumento de investimentos em obras de infra-estrutura e custeio de serviços. 
Por fim, na mensagem encaminhada ao prefeito Sérgio Sobral de Oliveira pelos organizadores do plano foi ressalvado que o projeto de lei procurou respeitar as recomendações do Plano Diretor de 1971, por meio de suas diretrizes, e contribuir para a diretriz principal - não incentivar a expansão horizontal no município.

\subsubsection{A Lei de Zoneamento de $1980^{68}$}

A elaboração da lei de zoneamento que viria suceder a lei $n^{0}$ 1606/71 se deu com a assinatura do contrato número 001/78, em 09 de janeiro de 1978, firmado pelo então Prefeito Eng $^{\circ}$ Ednardo José de Paula Santos e a empresa Lúcio Grinover Arquitetos Associados S/C Ltda.

O objeto deste contrato era bem maior do que a elaboração de uma nova lei de zoneamento. Versava sobre a assessoria e os serviços profissionais no âmbito do planejamento e desenho urbano, arquitetura, comunicação visual e desenho de produtos. O prazo acordado para os serviços contratados foi de quatro meses, a contar de 01 de janeiro de 1978, com término previsto para 30 de abril de 1978.

A empresa contratada apresentou, no decorrer do primeiro semestre de 1978, a minuta do projeto de lei de parcelamento, uso e ocupação do solo. Em 29 de junho de

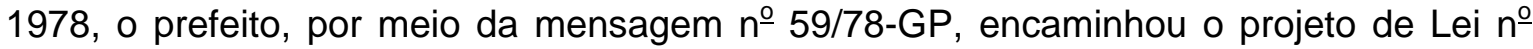
77/78 para a apreciação da Câmara Municipal.

Nessa mensagem, o prefeito argumentou que a lei de zoneamento em vigor (1606/71) tornara-se, com o correr dos anos, um instrumento imperfeito para o correto ordenamento do solo, pois a cidade encontrava-se num processo de rápida transformação por força de seu vertiginoso crescimento. Argumentou, ainda, que o projeto que estava encaminhando aproveitava a experiência legislativa anterior, mas também buscava o que de melhor havia a respeito dessa matéria, em diplomas

\footnotetext{
${ }^{68}$ Lei Municipal 2.263/80.
} 
legislativos de outros municípios, com a indispensável adequação à realidade de São José dos Campos.

Sobre o fato de buscar experiências de outros municípios, a lei proposta teve muita influência da lei geral de zoneamento de São Paulo (lei noำ 7805/72 de 01/11/72), na qual pudemos verificar que esta possui vários pontos e diretrizes comuns com a da cidade de São Paulo. Essa semelhança pode ser constatada quando as leis definem seus objetivos - os textos são idênticos.

A diferença é visualizada quando observamos a forma de representação da lei de São Paulo e de São José dos Campos que restringiam a forma de apresentação desses conceitos. Na primeira, os artigos foram feitos em forma de texto convencional e a segunda apresentou os conceitos em forma de quadro para um melhor entendimento dos usuários.

O ano de 1978 marcou a transição entre o período em que São José dos Campos tinha os prefeitos nomeados pelo governador, pelo fato de ser considerada Estância Hidromineral e as eleições diretas. Em 05 de outubro de 1977, por meio da lei ํo 1402, sancionada pelo então governador do estado, Dr. Paulo Egydio Martins, o município de São José dos Campos era excluído da condição de Estância Hidromineral.

Após a eleição de 15 de novembro de 1978, toma posse como primeiro prefeito eleito por voto popular, após a revolução de 1964, o Dr. Joaquim Vicente Ferreira Bevilacqua que, no ano seguinte, por meio da mensagem $n^{0} 45 / 79$, o novo projeto de lei no 44/79, que dispunha sobre o parcelamento, uso e ocupação do solo do município. A lei anterior - lei 1.606/71 - dispunha somente sobre o uso e ocupação do solo, enquanto que a lei $2.263 / 80$ foi mais abrangente e englobaram, em sua própria ementa, o parcelamento, o uso e a ocupação do solo.

Embora a lei 1606/71 não dispusesse sobre o parcelamento do solo à época de sua vigência, essa questão foi tratada pela lei 1.576 de 25 de setembro de 1970 . 
A lei 2.263/80, promulgada em 4 de janeiro de 1980 dividiu o município de São José dos Campos em um único perímetro de zona urbana e de expansão urbana e o remanescente como Zona Rural. A zona urbana e de expansão urbana foi subdividida em 15 zonas de uso, sendo cortadas por 16 corredores. Essa lei não teve sua origem vinculada a nenhum Plano Diretor, pois São José dos Campos vivia um período que não havia um Plano, muito menos diretrizes.

Naquele período de elaboração da lei, São José dos Campos tinha um Departamento de Planejamento, criado em 1976, cuja competência era elaborar o Plano de ação de governo, os Planos Setoriais e os programas necessários para implantação desses planos. Destacamos o Plano Diretor de Creches, de Equipamentos de Saúde, o projeto do Anel Viário, de drenagem das águas pluviais e o programa de transporte urbano.

No entanto, ao analisarmos seu texto, elaborado e complexo, podemos inferir que, pela primeira vez, o parcelamento do solo foi tratado em conjunto com as questões e diretrizes de uso e ocupação do solo.

Em comparação à lei 1606/70 também podemos observar que a lei 2263/80 apresentou uma novidade em relação às categorias de uso permitidas nas zonas de uso, essas seriam permitidas segundo dois grupos: uso conforme e uso sujeito a controle especial. O uso conforme era aquele permitido e incentivado na zona de uso, devendo ser respeitados os demais parâmetros urbanísticos mínimos estabelecidos para a zona de uso.

As categorias de uso sujeitas ao controle especial seriam aquelas que vieram a ser permitidas, desde que respeitados os parâmetros mínimos necessários, e atendessem a uma regulamentação específica de controle de poluição ambiental, níveis de ruído e horário de funcionamento especial.

As condicionantes das categorias de uso permitidas sob controle especial não foram regulamentadas no decorrer dos dez anos de vigência da lei 2263/80 e essas 
passaram a ser equiparadas, na prática, com categorias de uso permitidas nas zonas de uso.

No decorrer dos seus dez anos, a lei 2263/80 sofreu 94 alterações e modificações, sendo que o maior número de alterações ocorreu na gestão do Prefeito Robson Marinho (1983 a 1986) e as alterações mais freqüentes visavam prever e respaldar novas situações legais, não previstas ou não permitidas, que pudessem ajustar-se às novas demandas provenientes das mais diversas origens.

As situações mais comuns nessas alterações propostas eram no sentido de: a) alterar o zoneamento de uma determinada área ou região a fim de permitir uma determinada atividade outrora não permitida; b) criar novas zonas de uso com parâmetros de uso e ocupação específicos; c) restringir a verticalização em determinados bairros; d) reduzir parâmetros de ocupação solo e e) em outros incrementar a taxa de ocupação máxima ou o coeficiente de aproveitamento.

A disputa por espaços para a verticalização, muitas vezes, invadia e ocupava áreas antes destinadas ao uso residencial unifamiliar que causava confrontos e conflitos.

A competição pelo espaço também se deu entre a indústria e o setor imobiliário que transformava áreas industriais em áreas para urbanização residencial ou transformava áreas residenciais em áreas industriais. Essa transformação não significou uma substituição de atividades, mais do que isso, representou a substituição do capital industrial pelo capital imobiliário de incorporações. Exemplo dessa transformação de capitais foi a área da antiga Alpargatas onde hoje funciona um shopping center e a área remanescente foi parcelada em grandes lotes e implantados vários edifícios residenciais.

A disputa do capital imobiliário com o capital industrial por terras aconteceu mais na Região Leste do município.

Em abril de 1985, constituiu-se por meio do decreto 5.008/85 uma comissão para analisar e propor alterações na lei 2263/80. Essa comissão era composta por representantes da prefeitura e da sociedade civil. 
A existência de representantes da indústria, do comércio, do mercado imobiliário e da construção civil em órgãos colegiados como esse não se dava por acaso. A disputa do capital industrial, mercantil e imobiliário pelo espaço fizeram com que esses procurassem sempre se fazer presentes em todas as formulações e discussões que pudessem interferir em seus interesses relacionados com a terra, seu uso e seu preço.

Villaça (1998) chama a atenção de que preço de terra urbana tem dois componentes: um decorrente do seu próprio preço de produção e o outro do preço de seu monopólio. Esse último possui uma íntima relação com os produtos específicos resultantes da produção do espaço intra-urbano, em razão de suas localizações e acessibilidades, bem como dos artifícios produzidos pelas leis de zoneamento que podem incentivar, inibir ou proibir determinadas atividades ou formas construtivas.

Em 1986, a mais significativa alteração na lei $2263 / 80$ foi a retração do perímetro da Zona Urbana do município. Essa medida teve o intuito de reduzir as áreas disponíveis para o parcelamento do solo e evitar que, nas áreas mais distantes da mancha urbanizada e que não tinham a infra-estrutura necessária e adequada para esse fim, não fossem ocupadas.

Durante os anos de 1987 e 1988 quase não houve alterações na lei de zoneamento. Ao final de 1988 aparece, pela primeira vez, a figura das "Audiências Públicas", por meio da lei 3429/88, destinadas à avaliação de projetos de implantação industrial, loteamentos e atividades modificadoras do meio ambiente. No entanto, essa lei não foi regulamentada.

A lei 2263/80 introduziu uma série de inovações em relação à lei 1606/71: 1) exigir equipamentos destinados ao lazer para conjuntos habitacionais; 2) classificar as atividades industriais segundo padrões qualitativos e quantitativos, sendo fixados níveis máximos de emissões permissíveis; 3) elaborar uma listagem de atividades que foram classificadas segundo diversas subcategorias de uso comercial, de serviços e 
institucional; d) tratar o uso de uma determinada subcategoria de uso conforme, sujeito a controle especial ou não conforme.

Sobre os conjuntos habitacionais produzidos no período da lei $2263 / 80$ passaram a ser construídos, em sua maioria, verticalizados com vários blocos de apartamentos dotados de área de uso comum e coletivo contendo equipamentos de lazer ativo e contemplativo. Também verificamos que a construção dos conjuntos habitacionais só poderia acontecer em terrenos que fizessem parte de loteamentos aprovados, excluindo dessa forma, as glebas e vazios eventualmente deixados estrategicamente pela especulação imobiliária.

Destaca-se dessa lei o tratamento dado às zonas industriais e às tipologias de indústrias nelas permitidas, sendo este um dos pontos abordados na legislação e que não foi copiado da lei de São Paulo.

Decorrente dessa diretriz, foi questionada a implantação da Refinaria Henrique Lage e discutida não só a implantação da indústria, mas o que aconteceria no seu entorno, que era motivo de preocupação, pela possibilidade de atrair outras atividades industriais nos ramos de química, petroquímica o que viria agravar a implantação da refinaria e a qualidade de vida da população dos bairros vizinhos.

Destacamos nesse período a retração do perímetro urbano que pretendia reduzir as áreas disponíveis para o parcelamento do solo sob a figura do loteamento, evitando-os nas áreas mais distantes da mancha urbanizada e que não possuíam uma infra-estrutura necessária e adequada para esse fim. Essa atitude da administração municipal só veio a agravar o surgimento de inúmeros loteamentos clandestinos e irregulares por toda a área retraída do perímetro.

Concluindo, a lei $2263 / 80$ foi um zoneamento funcionalista em que a cidade foi dividida em polígonos, os quais determinavam o que era permitido. Essa forma de regulamentar o uso e ocupação do solo pressupõe que a cidade fosse imutável e rígida e 
as funções de morar, trabalhar e recrear deveriam ser desenvolvidas de uma forma rígida e detalhista.

\subsubsection{A Lei de Zoneamento de $1990^{69}$}

Após o estudo e a constatação sobre as dificuldades de aplicação da lei de zoneamento anterior ${ }^{70}$, formou-se um grupo de estudos composto por funcionários das Secretarias de Planejamento, Obras, Fazenda e Assuntos Jurídicos para a elaboração de uma nova lei de zoneamento.

O estudo para a elaboração da terceira lei de zoneamento de São José dos Campos começou no ano de 1987, com os seguintes objetivos específicos: 1) elaborar uma nova lei que contemplasse todas as alterações ocorridas na lei anterior e 2) tornar essa nova lei mais simples e de mais fácil entendimento para a população.

A proposta técnica de sistematização da lei de zoneamento foi concluída e apresentada ao prefeito Antonio José e aos secretários em junho de 1987.

Após a conclusão dessa primeira fase, iniciou-se o processo de discussão com a Comissão de Zoneamento ${ }^{71}$. Essa comissão reuniu-se, pela primeira vez, em 21 de dezembro de 1987 e era composta por funcionários da prefeitura e representantes da Associação dos Engenheiros e Arquitetos de São José dos Campos (AEASJC), da Associação Comercial e Industrial (ACl), dos empresários de loteamentos (AELO), do Instituto Nacional de Pesquisas Espaciais (INPE), da Associação das Construtoras do Vale do Paraíba (ACONVAP), do Escritório Regional de Planejamento (ERPLAN), da Câmara Municipal (CM) e das Regiões Administrativas da prefeitura (Sul, Norte, Leste e Centro). Essa comissão realizou mais 12 reuniões finalizando os trabalhos na reunião de 29 de março de 1988. Em 16 de maio de 1988 foi encaminhado ao prefeito o texto da lei de parcelamento, uso e ocupação do solo do município. Após as análises efetuadas pela

\footnotetext{
${ }^{69}$ Lei Municipal 3721/90.

${ }^{70}$ Lei Municipal $n^{\circ} 2.263 / 80$.

${ }^{71}$ Criada por meio do Decreto Municipal n 5.008 de 1 de abril de 1985.
} 
Assessoria Técnica e Legislativa (ATL) e pela Secretaria de Assuntos Jurídicos foi elaborado um projeto de lei $n^{0}$ 026/88 e publicado no Boletim do Município n ${ }^{\circ} 609$ em 19 de julho de 1988.

O ano de 1988 era eleitoral e o Prefeito Antonio José resolveu não encaminhar o projeto de lei à Câmara Municipal, deixando essa tarefa ao seu sucessor. Pela segunda vez elegeu-se prefeito Joaquim Bevilacqua, a quem coube novamente, a exemplo de 1979, discutir a aprovação de uma nova lei de zoneamento. Em 06 de abril de 1989, o prefeito encaminhou à Câmara Municipal a mensagem 023/ATL/89 referente ao projeto de lei que dispunha sobre o parcelamento, Uso e Ocupação do Solo do Município que tinha como objetivo principal a consolidação e sistematização das diversas alterações havidas na lei anterior ${ }^{72}$.

A Lei Municipal n $3721 / 90$ propôs a divisão do território do município em 30 zonas de uso e seis tipos de corredores especiais que, por sua vez, desdobravam-se em 72 vias públicas. Podemos observar que se o objetivo era o de simplificar, com certeza, com essas inúmeras zonas de uso, seus organizadores não conseguiram. Certamente, esse foi o objetivo primeiro de sua elaboração, comparada com a lei anterior. Podemos verificar que o número de zonas de usos duplicou de 15 em 1980 para 30 em 1990. Os corredores por sua vez quadruplicaram, passando de 16 vias em 1980 para 72 em $1990^{73}$

\footnotetext{
${ }^{72}$ Lei Municipal 2.263/80.

${ }^{73}$ Este zoneamento funcional ou funcionalista é um instrumento urbanístico que fixa qual as atividades que serão permitidas nas diversas zonas de uso, delimitadas segundo perímetros ou mapas. Ele é resultado dos planos urbanísticos difundidos nas primeiras décadas do século XX em congressos internacionais que consagraram o zoneamento como instrumento regulador de conflitos, de divisão funcional da cidade, separando residências de atividades comerciais, indústrias e de lazer. Como conceito, este instrumento foi defendido por Garnier e Le Corbusier a partir de 1928, no Congresso Internacional de Arquitetura Moderna (CIAM) e corroborado cinco mais tarde pela Carta de Atenas (SOMEKH, 1994). Neste $4^{\circ}$ Congresso realizado em 1933, elaborou-se a Carta de Atenas cujo conteúdo passou a ser o bem comum dos urbanistas (CHOAY, 1979).
} 
Este aumento do número das zonas de uso é devido ao desdobramento das Zonas Especiais (ZE's) criadas na vigência da lei 2.263/80 e das áreas de proteção ambiental (APA's), por causa de um estudo mais criterioso do meio físico (restrições e potencialidades) do município. Essas áreas foram regulamentadas a partir das restrições impostas pelo meio físico e das aptidões naturais provenientes de estudos efetuados por meio de um convênio entre a prefeitura e a CETESB, na década de 1980.

A Lei Municipal $n^{\circ} 3721 / 90$ fez a inserção de alguns corredores de uso especial em zonas de uso exclusivamente residencial (ZR's) e de uso especial (ZE's) que poderiam causar eventual descaracterização dessas zonas, uma vez que poderiam causar um transbordamento das atividades não residenciais. Estes corredores foram classificados segundo seis tipologias obedecendo a função e hierarquia desempenhadas no sistema viário.

Nos anos 80 ocorreu o surgimento de inúmeros loteamentos clandestinos, ocasionados pela própria rigidez dessa legislação, pela dinâmica do mercado e pela ineficácia da fiscalização do poder público local.

Destacamos também a criação da Zona de Vazio Urbano (ZVU), cuja ocupação e aproveitamento dependiam de uma análise de proposta de um plano ou projeto para sua ocupação pela Secretaria de Planejamento. Nessa análise eram avaliados os aspectos físico-territoriais da gleba e de seu entorno, as tendências do mercado imobiliário, bem como a infra-estrutura disponível.

No decorrer da década de 80 , foram registradas as ocorrências de vários loteamentos clandestinos que eram, em parte, produto da rigidez da legislação em relação à dinâmica do mercado imobiliário e, principalmente, da falta de fiscalização do poder público no seu território. Com o intuito de coibir a clandestinidade que vinha ocorrendo, a Lei Municipal no $3721 / 90$ criou um capítulo específico denominado "dos núcleos residenciais de recreio" e, para tanto, criou-se a zona de uso ZCHR que ocupava, aproximadamente, $60 \%$ do território do município. 
Sobre a Zona de Vazio Urbano (ZVU), essa era uma zona de uso que foi inserida na lei por causa das inúmeras glebas de médio e grande porte existentes no território do município. Diante da indefinição da aptidão dessas áreas, a sua ocupação e aproveitamento dependiam da análise de um plano ou de um projeto específico por parte da Secretaria de Planejamento e Meio Ambiente. Essa aptidão consistia na análise das questões físico-territoriais da gleba e de seu entorno, as tendências do mercado imobiliário, a infra-estrutura existente nas proximidades e, principalmente, a ocupação no entorno.

Com a finalidade de tentar coibir a clandestinidade que vinha crescendo ano a ano, foi criada na lei $3721 / 90$ um capítulo específico denominado "dos núcleos residenciais de recreio" que determinava uma zona de uso ZCHR - Zona de Chácaras de Recreio e o perímetro urbano foi retraído. Com o aumento do número de zonas de uso, das tipologias de corredores, das subcategorias de uso e das suas respectivas atividades foram construídos 82 quadros que se cruzavam para cada zona de uso e essa complexidade de informações reforçou o caráter funcionalista dessa lei de zoneamento.

Ocorreram 90 alterações na lei 3721/90, que visavam beneficiar interesses pontuais e foram introduzidas por meio de leis complementares. Essas sucessivas alterações e adaptações dessa lei e das anteriores são decorrentes de um princípio existente no modelo de zoneamento americano: a elasticidade.

Durante a vigência dessa lei, cerca de 12 leis de anistia destinadas às construções irregulares e clandestinas foram regularizadas, ou seja, dos 2920 dias de vigência dessa lei, 1252 dias foram vigorados por um tipo de anistia, cerca de $43 \%$ do período.

Essa lei de parcelamento, uso e ocupação do solo foi produto do trabalho da equipe de técnicos da prefeitura. Esse trabalho de várias secretarias foi uma consolidação de todas as alterações implementadas na lei 2263/80 que propôs a inclusão 
de novos instrumentos e tinha como meta principal a sistematização da lei de zoneamento anterior tornado-a mais simples e de mais fácil entendimento.

A proposta técnica foi concluída e apresentada em junho de 1987 iniciando o processo de discussão com a Comissão de Zoneamento que durou até 29 de março de 1988.

A lei $37121 / 90$ foi resultado da sistematização das diversas alterações da lei anterior, 2263/80. Essa sistematização teve a supervisão dos trabalhos feita pelos técnicos da prefeitura e o território de São José dos Campos foi dividido em 30 zonas de uso e seis tipos de corredores especiais que se desdobraram em 72 corredores.

Se a idéia inicial dessa lei era simplificar, pelo que podemos observar, o objetivo não foi alcançado, pois o aumento do número de zonas de uso constatado, pode ser creditado em razão de a lei ter absorvido grande parte das zonas de uso especial criadas na vigência da lei 2263/80. Como exemplo, podemos citar o desdobramento da zona de uso para Áreas de Proteção Ambiental em cinco: APA -1, APA -2, APA -3, APA 4 e APA - 5.

Em relação aos corredores especiais, esses mereceram um tratamento mais aprofundado e foram classificados segundo seis tipologias e obedeciam a uma função hierarquizada dentro do sistema viário.

Em relação ao parcelamento do solo foram criados três tipos de loteamentos diferenciados: A, B e C. Esses loteamentos possuíam exigências diferenciadas de obras e infra-estrutura que visavam estimular a iniciativa privada a produzir lotes urbanos para todas as classes sociais.

Com o aumento do número de zonas de uso, das tipologias de corredores, das subcategorias de uso e das suas respectivas atividades, houve necessidade de serem constituídos 82 quadros que se cruzavam para cada zona de uso, com informações de uso e ocupação do solo, mostrando que esta complexidade reforçava que a lei era claramente representada do zoneamento funcionalista. 
Ao longo dos anos de vigência da lei verificamos que foram feitas 90 alterações e mais 12 leis de anistia de construções, leis de regularização de construções irregulares e clandestinas.

Nesse período outro fato importante foi a discussão da destinação do uso do solo do entorno da Refinaria Henrique Lage, pois a população temia que bases de armazenagem e distribuição de derivados de petróleo pudessem vir a se instalar e, assim, aumentar o fator poluidor desse complexo, afetando os bairros vizinhos. 


\section{CAPÍTULO 4 - O PDDI DE 1995 "UM PLANO DA CIDADE PARA A CIDADANIA"}

Durante o processo constituinte, no final dos anos 80, o Movimento pela Reforma Urbana, composto por seis entidades populares nacionais e várias regionais, encaminhou ao Congresso Nacional uma proposta de Emenda Popular à Constituição com 160 mil assinaturas, contendo as reivindicações das classes populares urbanas com questões fundamentais referentes à propriedade imobiliária urbana, acesso à terra, habitação, gestão urbana, entre outras. (Villaça, 1999, p.232). Também fazia parte das reivindicações a inclusão de instrumentos urbanísticos que garantiriam a função social da cidade, da propriedade urbana e democratização da cidade.

As aspirações do movimento não foram atendidas, porém, pela primeira vez no país, a Constituição incluiu um capítulo que trata especificamente da política urbana que, além de estabelecer a possibilidade de aplicação de sanções à propriedade urbana que não cumpria sua função social, também reduziu o tempo para a aplicação do usucapião, que regulariza as posses urbanas. Instituiu também, a possibilidade de um regime progressivo de IPTU.

Segundo Villaça (1999), para neutralizar a pressão exercida pelo movimento e não realizar a reforma urbana proposta - que iria de encontro com os interesses imobiliários - foi introduzida na carta a obrigatoriedade da elaboração de Planos Diretores, medida esta que não era reivindicada por nenhum grupo, pelo menos explicitamente.

No entanto, o texto constitucional remeteu à legislação complementar e aos Planos Diretores municipais - definidos como obrigatórios para as cidades brasileiras com mais de 20 mil habitantes - a aplicação dos novos instrumentos de ordenação territorial e urbana. 
Esse vínculo estabelecido pela Constituição, de certa forma, estimulou um processo de renovação conceitual e metodológica na produção de Planos Diretores municipais, a partir de 1988 e, sobretudo, a partir dos mandatos dos prefeitos eleitos em 1989.

A partir daí, vários municípios introduziram estratégias e alguns instrumentos inovadores em sua legislação urbanística e houve uma grande preocupação com o próprio processo de elaboração, procurando ampliar a participação da sociedade civil no planejamento e na gestão da cidade.

Em São José dos Campos, um novo plano começou a ser elaborado a partir do segundo semestre de $1988^{74}$ quando foi efetuado o levantamento de dados socioeconômicos do município e, em 1990, foi elaborado um censo escolar que atendia a Lei Orgânica do Município que, pela Constituição de 1988, passou a ser específica para cada município.

Esse plano foi coordenado pela Secretaria de Planejamento e Meio Ambiente e resultou num trabalho desenvolvido entre as equipes técnicas das Secretarias e Fundações da Administração Municipal. Participaram desse estudo, os órgãos estaduais e as Concessionárias de Serviços Públicos Municipais que acolheram sugestões da população participante da primeira audiência pública, realizada em outubro de 1991, e sugestões encaminhadas pelos segmentos organizados da sociedade.

Em 1991, ficou constatado pelos integrantes do grupo de estudo que, para a continuidade dos trabalhos, havia necessidade de ser contratada uma assessoria para dar suporte técnico à Secretaria de Planejamento para coordenar e elaborar o Plano Diretor.

\footnotetext{
${ }^{74}$ A Constituição Federal de 1988, em seu artigo 182, instituiu a obrigatoriedade da utilização do Plano Diretor como instrumento básico da política de desenvolvimento e expansão urbana das cidades com mais de vinte mil habitantes com o objetivo de ordenar o pleno desenvolvimento das suas funções sociais e garantir o bem-estar de seus habitantes.
} 
Assim, foi contratada a Assessoria da Universidade Estadual Paulista UNESP - Rio Claro, que já possuía experiência em assessorar vários planos no Estado de São Paulo e no Brasil. A equipe da universidade, juntamente com as equipes técnicas das Secretarias e Fundações da Administração Municipal realizou vários seminários e debates sobre a forma de se realizar um Plano Diretor e as conseqüências que esse trabalho traria para o município. No início de 1993, foi apresentado à Administração Municipal o primeiro volume do Plano, denominado Plano Preliminar.

Em função da mudança de governo em 1993, o Plano Preliminar foi encaminhado aos novos Secretários da Administração e Diretores das Fundações para conhecimento, análise e sugestões. Esse documento ressaltou que a participação e o direcionamento seriam dados pelos administradores locais e, principalmente, que a elaboração de um documento final deveria refletir, não só os aspectos técnicos como também incorporar as intenções da administração que assumia a Administração Pública.

No início do ano de 1994, foi realizada uma reunião do secretariado para apresentação do Plano Preliminar. Nessa reunião foram enfatizados os aspectos das políticas públicas contidas no Plano, que viriam a subsidiar sua primeira apresentação num Fórum de Desenvolvimento com o objetivo de discutir as diretrizes nele contidas com os representantes da sociedade civil.

Uma segunda apresentação foi feita, exclusivamente, para o secretariado do município, em fevereiro de 1994; com o objetivo de elaborar as determinações finais da proposta do PDDI. Nessa reunião, ficou acordado que deveriam ser divulgadas, para o conjunto da Administração, as diretrizes propostas no PDDI.

Uma terceira reunião foi realizada para a apresentação do Plano Preliminar para as Chefias de Divisão e funcionários da Administração, com o objetivo de possibilitar uma melhor compreensão desse estudo, quando foi feita uma divisão dos aspectos abordados em quatro temas e estabelecido um calendário das discussões setoriais por tema. 
Como complementação desse estudo, em 28 de março de 1994, por sugestão da Secretaria de Governo e da Secretaria de Planejamento e Meio Ambiente, foi convidada a Arquiteta Raquel Rolnick, Diretora de Planejamento da Administração de Luíza Erundina, prefeita da cidade de São Paulo, para uma palestra sobre o tema: "A experiência do Plano Diretor de São Paulo".

$\mathrm{Na}$ apresentação, a palestrante relatou experiências de alguns Planos Diretores que vinham sendo elaborados no Brasil e como se deu o processo de elaboração do Plano Diretor do Município de São Paulo.

Concluído esse processo de discussão e de elaboração de propostas advindas das diversas reuniões setoriais, com a participação das equipes técnicas dos diversos setores da prefeitura, foi publicado o volume intitulado "Plano Diretor de São José dos Campos - Um Plano da Cidade para a Cidadania".

Nessa segunda etapa dos estudos destacamos a elaboração da Carta das Unidades Territoriais, cujo objetivo era indicar a capacitação do solo para todo o território do município e a elaboração da proposta de um macrozoneamento, baseado na Carta produzida pelo INPE, em 1992, no Plano Regional do MAVALE, detalhado no item 3.1.5.

Com base nesse estudo, o PDDI de São José dos Campos aprofundou o conhecimento, em nível local, dos aspectos físico-geográficos, sociais e econômicos, definindo as potencialidades e limitações, para seu desenvolvimento, em cada região do seu território. A partir dessa Carta, também foi definido um novo perímetro urbano, o de expansão e o rural do município, e as áreas que deveriam ser especialmente protegidas, transformadas em quatro Áreas de Proteção Ambiental, gerando a Carta do Macrozoneamento de São José dos Campos. (fig 4.1) 


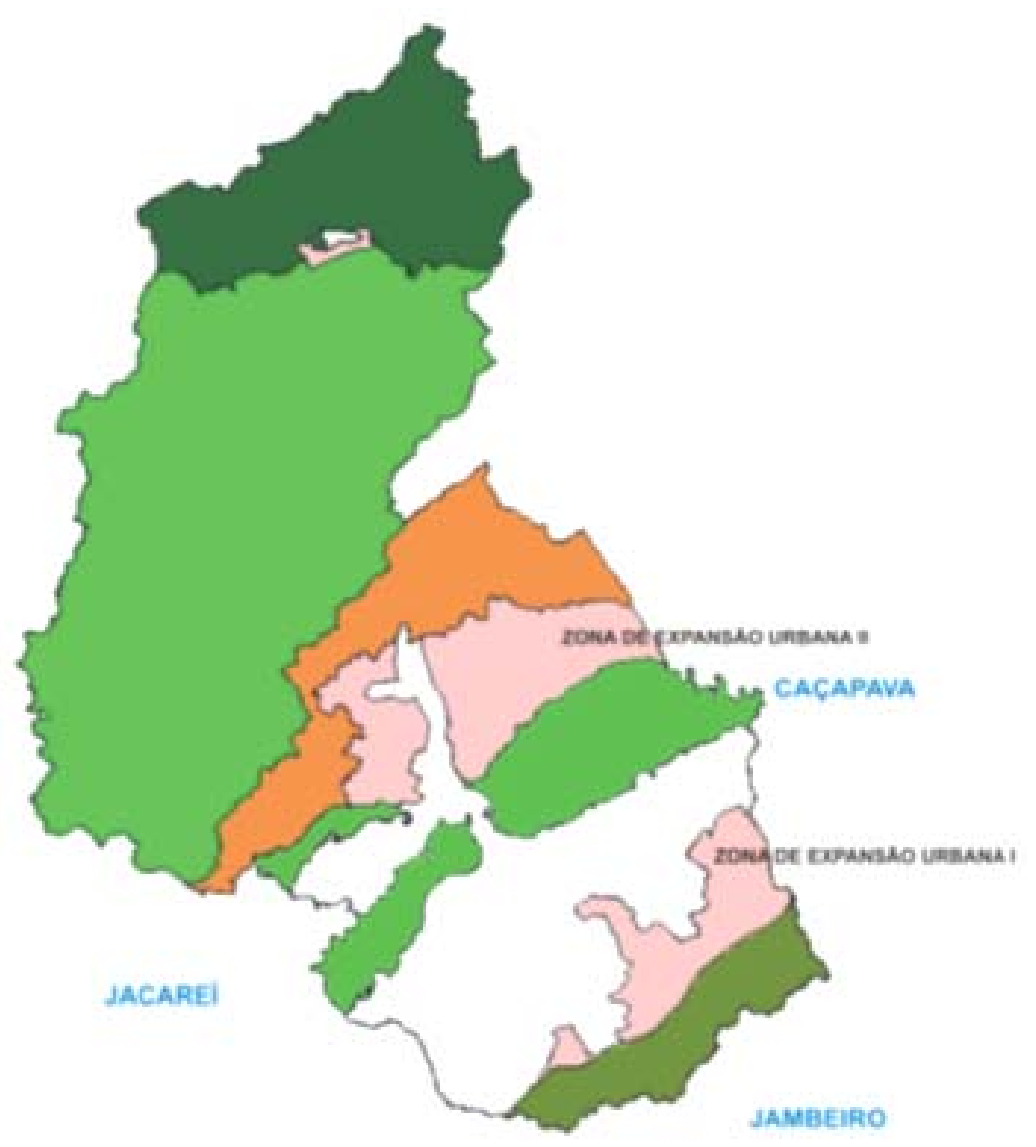

Figura 4.1 - Macrozoneamento proposto no PDDI de 1995 Fonte: PMSJC, 1995.

Durante a realização desses estudos, foram previstos os principais eixos norteadores do processo de planejamento que tinham a finalidade de atender um dos principais lemas do Plano Preliminar: tornar o município um "o espaço onde é bom viver e conviver".

Com o objetivo de divulgar o Plano e também de receber críticas e sugestões, no período entre 05 de setembro e 29 de novembro de 1994 foram realizadas 20 reuniões com entidades representativas da sociedade civil: Sindicato dos Trabalhadores (05 de setembro); Representantes das Indústrias (12 de setembro); Universidades e Centros de Pesquisas e Escolas (15 de setembro); Sociedades Amigos de Bairro das Regiões Administrativas Centro, Norte, Leste, Sul; Sindicato da Construção Civil (20 de 
setembro, 27 de setembro, 11 de outubro, 18 de outubro ${ }^{75}$ e 22 de outubro); Sindicato da Indústria e Comércio (24 de outubro); Empresa Petrobrás (26 de outubro); Indústria e Comércio (27 de outubro); Comissão Permanente de Zoneamento (03 e 17 de novembro); Vereadores da Bancada Situacionista (22 de novembro); Comunidade Cristã (28 de novembro); CIESP (29 de novembro) e Associação dos Moradores de Loteamentos (29 de novembro).

De acordo com o relatório do processo de elaboração e discussão do PDDI, datado de 1994, a administração municipal entendia que a prática de realizar reuniões com a sociedade civil trouxe, além de riqueza para seus resultados, a prática de uma administração democrática e popular na promoção e acesso às informações. Além disso, mostrou que a efetiva participação dessa população, tornava a elaboração do Plano um verdadeiro exercício de Cidadania.

No período de 02 a 05 de dezembro de 1994, foram realizadas reuniões com o corpo técnico, no auditório do Paço Municipal, para a sistematização dos resultados da Audiência Pública. O projeto de lei foi encaminhado para a Câmara Municipal no dia 06

\footnotetext{
75 Segundo Ata da Reunião com a SAB da Região Sul, 18/10/94, destaca-se: "O Arquiteto Emmanuel Antonio dos Santos, Diretor de Planejamento Urbano, faz menção à hierarquização legal vinculada ao PDDI, colocando-o em seu contexto institucional e legal em relação às Constituições Federal e Estadual [...] Expõe as diversas formas de divulgação do PDDI e discorre sobre a simplicidade da linguagem do folheto denominado"Receita de cidade" [...] Comenta a preocupação do Plano quanto à inserção de São José dos Campos no contexto do Vale do Paraíba a partir de uma visão produzida pelo projeto MAVALE [...] aborda o papel do CODIVAP como meio [...] explica aos presentes a forma pela qual foi produzida a atual proposta de macrozoneamento, elaborada a partir da avaliação dos elementos levantados pelo diagnóstico e da Carta das Unidades Territoriais. [...] Após apresentação das etapas da elaboração do Plano Diretor os presentes questionaram o Sr. Diretor: Quais os critérios para a aplicação do IPTU Progressivo? O Sr. Diretor responde: "O objetivo do IPTU progressivo é o de corrigir distorções e que somente serão atingidos os especuladores imobiliários, explica sobre o processo de especulação imobiliária que vem ocorrendo na cidade e comenta que este instrumento é uma forma de garantir a função social da propriedade urbana". [...] O Sr. Diretor fala da política fiscal, dos desvios que ocorrem com os recursos arrecadados com o ITR, da necessidade de se assumir a municipalização na arrecadação dos impostos territoriais rurais gerados no Município, por meio da criação da ITRM com conseqüente reaplicação dos recursos obtidos na própria zona rural do Município, estabelecendo uma política agrária autônoma. Coloca a necessidade de estimular a retomada da produção e do desenvolvimento e comenta que noventa e cinco por cento das necessidades de consumo do Município são importados de outros centros de produção hortifrutigranjeiros e cereais. Observa que o equipamento da zona rural poderia ser financiado com recursos oriundos desse desenvolvimento retomado.
} 
de dezembro de 1994. O PDDI foi aprovado em 9 de junho de 1995, por meio da Lei Municipal Complementar 121/95.

O perímetro de expansão urbana foi estendido na face Sul do Município até a Rodovia Carvalho Pinto e, ao Norte até o limite definido na Carta de Unidades Territoriais com potencial para ocupação urbana. O PDDI apontou o vetor de crescimento urbano para a Região Leste, em função das condições físicas favoráveis e da proximidade com a Rodovia Carvalho Pinto.

Na redefinição dos perímetros, foram incorporados ao perímetro de expansão urbana, cerca de 50 loteamentos clandestinos, situados na Zona Rural. Estes totalizavam 3.223 domicílios em 1996 e uma população estimada de 13.517 habitantes, conforme dados da Divisão de Pesquisas da Secretaria de Planejamento de São José dos Campos.

Através desta medida, o PDDI incorporou a cidade ilegal à cidade formal com a intenção de cumprir um dos objetivos do Plano que era o de possibilitar a futura regularização urbanística e fundiária desses assentamentos. Ressaltamos que, naquele período, o processo de ocupação clandestina já estava em ritmo acelerado nas Regiões Norte e Leste, assunto que será objeto da análise de estudo de caso apresentado no item 4.3.

Esse novo modelo de gestão urbana, proposto no Plano Diretor de 1995, provocou nova postura do governo local que estava, até então, voltado para a indução de atividades econômicas, de fontes de renda e de ofertas de emprego para a promoção da atratividade e da competitividade das cidades. Nesse modelo, caberia aos agentes particulares um papel mais ativo, por meio de formas associativas e de parcerias com o poder público na promoção de empreendimentos.

Sobre os instrumentos de política urbana que foram propostos para dar suporte a essa nova postura do governo local e às demais diretrizes contidas no Plano, foram previstas as seguintes ações: operação urbana, operação interligada, urbanização 
consorciada, imposto progressivo no tempo e o parcelamento ou edificação compulsória. Por meio destes instrumentos, propôs-se estabelecer trocas com a iniciativa privada, a exemplo de habitações de interesse social ou obras de infra-estrutura, como também controlar o valor especulativo da terra por meio do IPTU progressivo no tempo e do coeficiente único.

Destacamos também, a proposta das Zonas Especiais de Interesse Social (ZEIS), que tinham como diretriz promover a regularização urbanística das áreas de favela e loteamentos clandestinos de interesse social. Esses instrumentos foram definidos conceitualmente no PDDI; entretanto, sua regulamentação ficou prevista para uma fase posterior, após discussão ampla com todos os segmentos da sociedade.

Segundo o Plano Diretor de 1995, ficou constatado que havia ineficiência de uma política habitacional em São José dos Campos que acompanhasse o acelerado processo de urbanização do município. A falta de uma política habitacional mais eficiente contribuiu, de certa forma, para o aumento do déficit habitacional para a população de baixa renda que vinha ocorrendo, até aquele ano, aliada às altas taxas de crescimento demográfico e a perda de poder aquisitivo da população.

Essa constatação surgiu dos dados da pesquisa de instrumentação do Planejamento Urbano, realizada pela Prefeitura Municipal em 1992. Esta pesquisa evidenciava que $72 \%$ dos domicílios de São José dos Campos eram de propriedade dos moradores. Esse fato, porém, não implicava em que essas famílias estivessem morando em condições satisfatórias e que, apenas $28 \%$ delas deveriam ser consideradas como demanda pelo poder público.

A pesquisa constatou, ainda, que das 109.280 famílias entrevistadas, 106.420 residiam em domicílios unifamiliares e demonstravam que 5.800 famílias viviam em condições de coabitação, ou seja, mais de uma família morava em um único domicílio. Constatou-se ainda que, das 30.580 famílias que não dispunham de moradia própria, 
69,5\% delas situavam-se na faixa de renda de 10 salários mínimos, residindo em moradias alugadas, cedidas ou em favelas.

Dentre as diversas situações de moradia apresentadas por essa pesquisa, destacaram-se aquelas situadas na periferia da área urbana. Tratava-se de assentamentos habitacionais precários, sem regularização urbanística e/ou fundiária, excluídos do processo de urbanização da cidade. Incluem-se aí os loteamentos irregulares, as favelas, os cortiços e outros, que fazem parte da cidade real ${ }^{76}$ (incluindo a informal) em contraposição à cidade legal (formal).

O PDDI de 1995 traçou como diretriz a implementação de uma política habitacional que possibilitasse o acesso da população de baixa renda à cidade, associada a uma política de desenvolvimento urbano abrangente que trabalhasse com a cidade real e não apenas com a cidade legal.

Com base nesse argumento, o Plano Diretor de 1995 propôs as seguintes diretrizes para a área habitacional:

a) elaboração e implantação de plano de regularização urbanística e fundiária em favelas, loteamentos clandestinos e irregulares;

b) criação de banco de terras destinado à habitação popular;

c) implantação de plano de gerenciamento e recuperação de áreas de risco;

d) reformulação da lei de parcelamento e uso do solo e do código de obras, adequando-os à realidade local;

e) elaboração de lei específica sobre habitação de interesse social;

f) implantação de sistemas de financiamento baseados em critérios sociais compatíveis com a realidade da população beneficiada;

g) criação e regulamentação das ZEIS;

\footnotetext{
${ }^{76}$ Os técnicos convencionaram denominar "cidade real": a cidade definida não só a partir da legislação existente, mas do espaço conjunto edificado, onde estão contidos inclusive assentamentos ilegais e irregulares.
} 
h) implantação de programas e elaboração de projetos de acordo com as deliberações do Colegiado Municipal de Desenvolvimento Urbano ${ }^{77}$.

Sobre a Zona de Interesse Social - (ZEIS), esta foi destinada à promoção de Habitação de Interesse Social (HIS) e à regularização fundiária e urbanística de áreas ocupadas irregularmente por assentamentos habitacionais de população de baixa renda. Embora a contra-proposta sugerisse não listar as favelas existentes, não urbanizar e nem fazer a regularização fundiária de assentamentos urbanos em áreas públicas e de que todos os melhoramentos levados pelo Poder Público às ZEIS, deveriam ser cobrados. Os que não pudessem pagar comprovadamente, seriam isentos, como já ocorria na Legislação do IPTU.

Apesar dessa proposta, as ZEIS foram classificadas em três tipos. Apresentamos a tabela (4.1) ilustrativa da situação das favelas que compunham a ZEIS 1 naquele período.

Tabela 4.1 - Relação das favelas indicadas para ZEIS 1 em 1996

\begin{tabular}{llcc}
\hline \multicolumn{1}{c}{ Região Centro } & \multicolumn{1}{c}{ Endereço } & $\begin{array}{c}\mathbf{N}^{\circ} \text { de } \\
\text { moradias }\end{array}$ & $\begin{array}{c}\mathbf{N}^{\circ} \text { de } \\
\text { moradores }\end{array}$ \\
\hline Vila Santa Cruz I & Av. Teotônio Vilela (fundo do Vale) & 254 & 1.080 \\
Vila Santa Cruz II & Av. Teotônio Vilela (fundo do Vale) & 78 & 322 \\
Vila Santa Cruz III & Av. Teotônio Vilela (fundo do Vale) & 84 & 341 \\
Jd.Nova Esperança & Av. São José (Banhado) & 283 & 1.302 \\
Jd. das Indústrias & Av. Corifeu de Azevedo Marques & 56 & 235 \\
Vila Abel & Travessa Ozanã & 29 & 128 \\
Vila Guarani & Vila Guarani & 26 & 140 \\
Caramujo & Próximo Av.Tamoios & 11 & 68 \\
Região Norte & \multicolumn{1}{c}{ Endereço } & $\mathbf{N}^{\circ}$ de & $\mathbf{N}^{\circ}$ de \\
& \multicolumn{2}{c}{ moradias } & moradores \\
Vila Rhodia & Av. Pedro Rachid Santana & 120 & 600 \\
Vila Sinhá & Av. Conde Francisco Matarazzo & 48 & 220 \\
& & & continua
\end{tabular}

${ }^{77}$ O Colegiado Municipal de Desenvolvimento Urbano - CMDU - tinha como função articular as ações desempenhadas pela Comissão de Zoneamento e pelos conselhos de representação da sociedade civil junto à Prefeitura, como: Conselho Municipal do Meio Ambiente, Conselho Municipal do Patrimônio Histórico e Conselho Municipal de Habitação. O CMDU teria o caráter consultivo e deliberativo, nos assuntos citados nesta pré-proposta e sua composição era por 21 membros, com direito a voto, distribuídos paritariamente da seguinte forma: 10 representantes de poder executivo municipal, 10 representantes de entidades da sociedade civil e um representante do chefe do executivo, que o presidirá e que somente votará em caso de empate. 


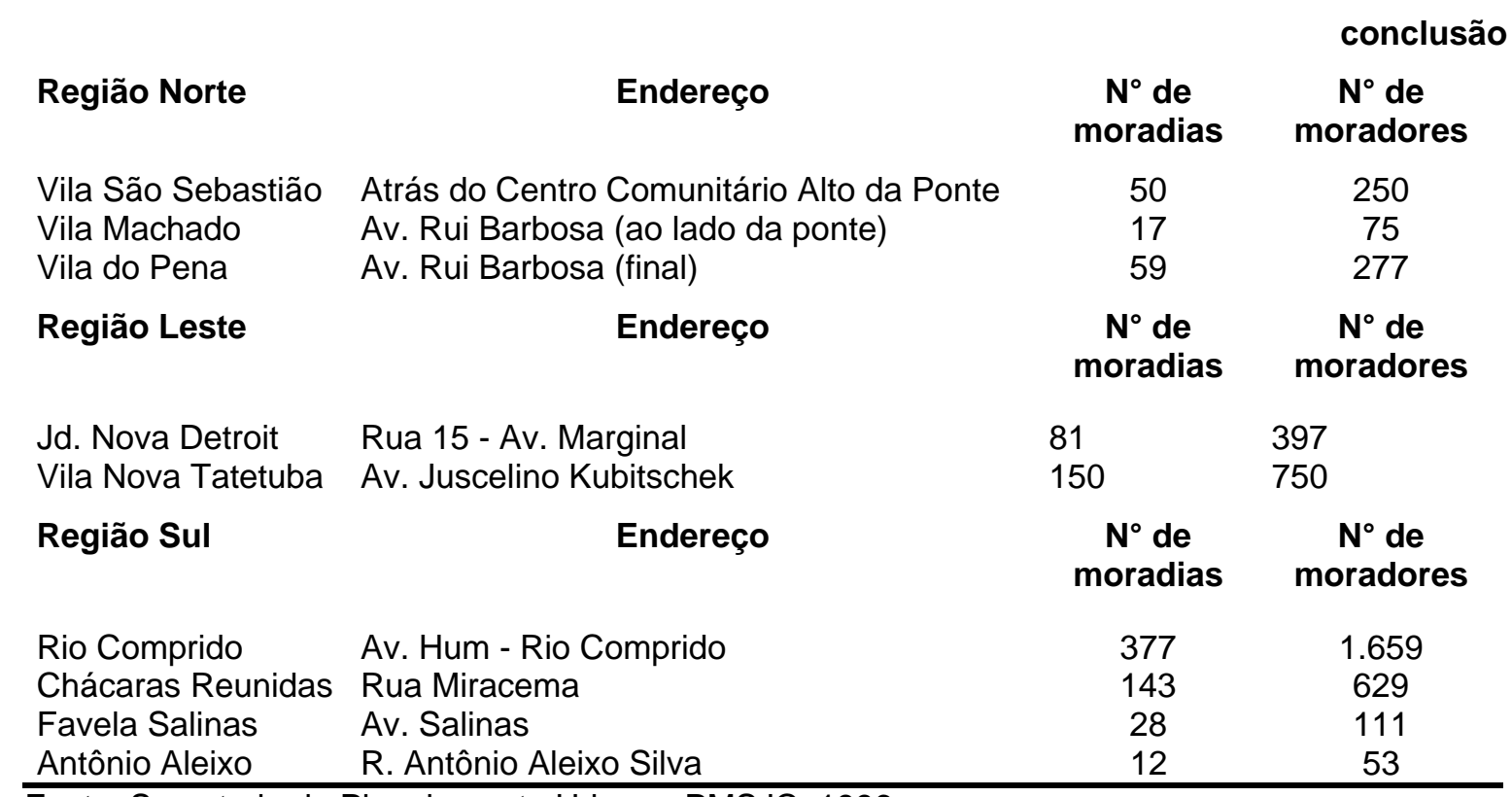

Fonte: Secretaria de Planejamento Urbano, PMSJC, 1996.

Assim como em grande parte dos municípios médios brasileiros, em São José dos Campos, foi criada a Zona Especial de Interesse Social - ZEIS, mas essa não foi operacionalizada e não se regulamentou a habitação de interesse social. Segundo Flávio Villaça (2005), muitas vezes, as ZEIS teriam sido incluídas na legislação para que o município aparentasse ter uma política habitacional, mas sem operacionalização, como nos "planos não aplicáveis".

Em relação aos problemas habitacionais, esses já tinham sido identificados, primeiramente, no Plano Setorial do Plano CEPEU-USP, em 1964, (detalhado no item 3.3) e, para tanto, este Plano já previa, em suas diretrizes, a constituição de um Fundo Municipal de Habitação e o planejamento Físico das Áreas Habitacionais, no entanto, essas não foram implantadas.

As estratégias e diretrizes elaboradas no Plano CEPEU -USP se limitaram ao desfavelamento da Linha Velha para construção de um eixo viário sobre o seu antigo leito (atual Avenida Fundo do Vale) e que a formulação de Convênio entre a Prefeitura e a Caixa Econômica Estadual beneficiava apenas as faixas de renda que se enquadravam nos requisitos do sistema financeiro vigente naquela época. 
No Plano Serete S.A. de 1971, discutido no item 3.4, para a política habitacional pudemos verificar que este teve uma ação um pouco mais intensiva, pois foram adotadas como medidas: a previsão e o estímulo para a construção de conjuntos habitacionais, a indicação de áreas preferenciais para implantação desses conjuntos e estímulo à criação de novos loteamentos somente nas áreas previstas para serem adensadas.

Constatou-se ainda que houve falta de uma política específica para a habitação popular, não só em relação ao PDDI de 1971, mas também em relação às administrações que se sucederam, principalmente, face ao acelerado desenvolvimento industrial iniciado na década 70.

A contenção da expansão horizontal associada à política de construção de conjuntos habitacionais para classes de renda que se enquadravam nos critérios de financiamento do Sistema Financeiro da Habitação, demonstrou-nos que o PDDI de 1971 não considerou a parcela da população de baixa renda na política habitacional.

A partir dos anos 70, o município realizou as primeiras ações voltadas para o setor habitacional baseadas, assim como o Plano do CEPEU - USP, na erradicação de favelas como foi o caso do conjunto habitacional do Torrão de Ouro, criado para abrigar a população da favela da Linha Velha. Ressalta-se ainda que, o objetivo central se limitou apenas na transferência de parte da população da favela para a Região do Torrão de Ouro para viabilizar a execução de projetos de interesse público do município, ou seja, a construção do Paço Municipal e parte do Anel Viário, correspondente à Avenida Senador Teotônio Vilela.

Somente em abril de 1979, com a criação da Empresa Municipal de Habitação - EMHA, o Poder Público passou a implantar um programa que visava suprir a demanda habitacional existente naquela época. Para tanto, elaborou um plano para uma gleba localizada na Região Sul do município e construiu o Conjunto Habitacional Torrão de Ouro (fig. 4.2) distante 12 km da Região Central. 


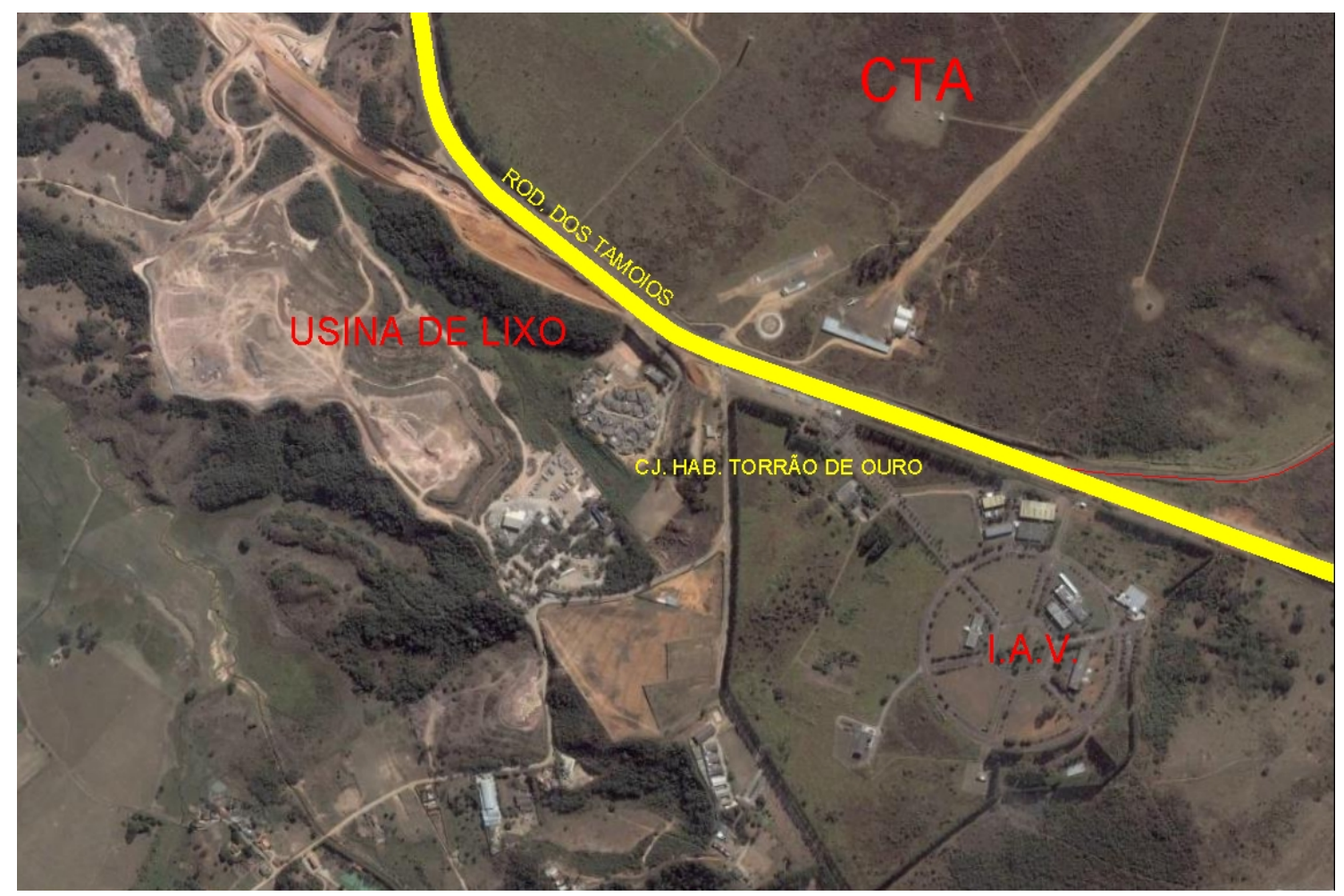

Figura 4.2 - Conjunto Residencial Torrão de Ouro Fonte: Google Earth, 2006.

Após a implantação desse conjunto, o programa habitacional sofreu nova paralisação, sendo retomado somente a partir de 1987, por meio do programa de lotes urbanizados denominado Campo dos Alemães I e II.

Posteriormente, em 1991, foram implantados os Conjuntos D. Pedro I e II na Região Sul com, aproximadamente, 4 mil unidades domiciliares financiadas pelos Governos Federal e Estadual, por meio do Plano de Ação Imediata de Habitação Popular - PAIH e da Companhia de Desenvolvimento Habitacional e Urbano - CDHU respectivamente.

A complexidade da legislação urbanística e edilícia de São José dos Campos criada, muitas vezes, com a intenção de garantir ótimos patamares de qualidade de vida urbana e habitacional, acompanhada da falta de fiscalização e punição contra os infratores, levou à colocação de grande parte dos moradores na ilegalidade. Além de se tornar um obstáculo para o acesso aos serviços urbanos, a ilegalidade carrega consigo a impossibilidade de obtenção de financiamento (de fontes públicas e privadas) para 
melhoria, reforma ou ampliação das habitações, já que os financiamentos exigem como garantia a titulação plena da propriedade.

O resultado dessa diretriz mostrou que os projetos executados até hoje estão mais relacionados com regulamentos urbanísticos e que, por meio da vigente lei de parcelamento do solo, ${ }^{78}$ que abrange apenas a relocação de favelas para locais distantes do centro e os loteamentos clandestinos, continuam a se adensar e não há uma política habitacional abrangente.

Em relação aos loteamentos clandestinos, esses continuaram a surgir na periferia de São José dos Campos, em menor número do que na década de 80, porém, em grande quantidade.

São José dos Campos possui hoje 94 loteamentos deste tipo, com forte tendência ao adensamento. No entanto, a Secretaria de Habitação confirma que o verdadeiro número de loteamentos clandestinos existentes em São José dos Campos poderia ultrapassar 200.

Verificamos também que o fato de a administração não querer enxergar a cidade real não é novidade, uma vez que durante a primeira reunião da comissão de zoneamento, realizada em 08 de maio de 1996, para discutir a regulamentação da préproposta da lei de regulamentação do Plano Diretor de 1995, este fato foi apresentado aos participantes ao ser enfatizado em uma de suas atas: "[...] para o planejamento da cidade é necessário que a cidade real seja enxergada [...] a cidade irregular e clandestina deve ser incorporada de forma global ao seu plano de uso e ocupação do solo".

Os estudos do PDDI de 1995 atribuíram o problema ao fato de não haver articulação entre política urbana e política habitacional e ainda:

a) à ausência de canais para a participação popular na gestão dos recursos e da política habitacional;

b) à exclusão dos usuários ao se conceber programas e projetos;

\footnotetext{
${ }^{78}$ Lei Municipal $n^{\circ}$ 165/97 de 15 de dezembro de 1997.
} 
c) à concepção da unidade pronta como única forma de acesso à moradia;

d) à adoção de soluções padronizadas e uniformizadas;

e) à implantação de programas em periferias, incentivando a especulação imobiliária nas faixas intermediárias da cidade;

f) ao não atendimento das demandas da cidade real através da produção habitacional pública.

Com a intenção de atender a diretriz do PDDI de 1995, que trata sobre a inclusão dos loteamentos clandestinos existentes fora do perímetro urbano de São José dos Campos, foram criadas duas zonas de expansão urbana, uma ao Norte e outra ao Sul que engloba a grande maioria dos loteamentos existentes no território da cidade.

Esta proposta teve o objetivo de fazer com que os novos perímetros de expansão urbana possibilitassem o aumento na oferta de terras urbanizáveis, estimular a diminuição dos preços fundiários; possibilitar a regularização da maior parte dos assentamentos clandestinos, ao mesmo tempo que visava garantir a permanência de áreas produtivas e a preservação dos recursos naturais nas unidades identificadas no macrozoneamento elaboradas pelo INPE em 1992.

Segundo dados da Secretaria de Obras e Habitação da Prefeitura Municipal, a partir de 1997, foram detectados 25 loteamentos clandestinos na Zona Urbana e mais nove na Zona Rural, totalizando 34 novos loteamentos clandestinos, sendo que foram paralisados 11 loteamentos através de diversas ações conjuntas com o Ministério Público. Nos demais, existem ocupações com tendência ao adensamento.

Em relação à política para a habitação social, podemos dizer ainda que, medidas mais efetivas foram implantadas, envolvendo a relocação das favelas Caparaó, Nova Detroit e Morro do Regaço, para o loteamento Jardim São José, totalizando 1.250 unidades habitacionais, e a construção de 84 unidades habitacionais em sistema de mutirão, relativa à relocação da favela Salinas, todos com recursos oriundos do BIRD. 
Paralelamente, o Poder Público executou obras de infra-estrutura, de drenagem, pavimentação, urbanização de praças e arborização de vias públicas, com recursos próprios, no Bairro Campos dos Alemães. Esse projeto atendeu à população já consolidada de, aproximadamente, 35 mil habitantes. Portanto, houve ações de política habitacional nesse município.

Em São José dos Campos, até o início do ano 2000, ainda não haviam sido viabilizados investimentos para a construção de novas unidades de interesse social e regularização urbanística e fundiária dos 120 loteamentos clandestinos, detectados antes da elaboração do PDDI.

Em 2003, de acordo com estudo elaborado pelo Núcleo de Estudos de População da Universidade de Campinas (NEPO) em conjunto com a Secretaria de Planejamento que, a partir de levantamento de campo amostral visava dimensionar o déficit habitacional em São José dos Campos, constatou que o município possui um déficit habitacional imediato e estimado de 2.559 residências. Trata-se de um déficit por reposição ${ }^{79}$, conforme metodologia adotada pelo NEPO instituto responsável pela pesquisa. (Tabelas $4.2,4.3$ e 4.4 a seguir)

\footnotetext{
${ }^{79}$ No cálculo do déficit por reposição foram considerados os domicílios sem condições básicas de habitação: os que não apresentam paredes de alvenaria ou madeira aparelhada, os cômodos, e os domicílios que, embora contem paredes de alvenaria ou madeira aparelhada, não possuem instalações sanitárias, ou possuem instalações sanitárias compartilhadas. Também foi considerado o número de domicílios improvisados computado pelo Censo 2000, que foi de 457 domicílios.
} 
Tabela 4.2 - Moradias sem condições básicas adequadas de habitação em São José dos Campos - 2003

\begin{tabular}{|c|c|c|c|c|c|}
\hline Regiões & Cômodos & $\begin{array}{l}\text { Casas construídas } \\
\text { com material } \\
\text { reaproveitado ou } \\
\text { outro material }\end{array}$ & $\begin{array}{l}\text { Casas de alvenaria elou } \\
\text { madeira aparelhada com } \\
\text { sanitário de uso comum } \\
\text { a mais de um domicílio }\end{array}$ & $\begin{array}{c}\text { Casas de } \\
\text { alvenaria elou } \\
\text { madeira } \\
\text { aparelhada sem } \\
\text { sanitário }\end{array}$ & $\begin{array}{c}\text { Total de moradias } \\
\text { sem condições } \\
\text { básicas } \\
\text { adequadas de } \\
\text { habitação }\end{array}$ \\
\hline 1.Centro & 23,66 & 58,78 & 11,83 & 5,73 & 262 \\
\hline 2. Leste & 23,22 & 55,21 & 18,96 & 2,61 & 422 \\
\hline 3. Norte & 11,38 & 78,04 & 4,59 & 5,99 & 501 \\
\hline 4. Oeste & 0 & 100,00 & 0 & 0 & 56 \\
\hline 5. Sudeste & 50,00 & 8,24 & 33,53 & 8,24 & 170 \\
\hline 6. Sul & 54,34 & 36,71 & 8,96 & 0 & 346 \\
\hline $\begin{array}{l}\text { 7. Favelas e } \\
\text { Ocupações } \\
\text { irregulares }\end{array}$ & 5,83 & 91,25 & 2,92 & 0 & 343 \\
\hline TOTAL & 51058,78 & 1.288 & 232 & 70 & 2.100 \\
\hline
\end{tabular}

Fonte: Pesquisa de instrumentação do planejamento urbano e avaliação do déficit habitacional em São José dos Campos. NEPO/UNICAMP/PMSJC, 2003.

Por outro lado, além dos domicílios que devem ser repostos, existe a necessidade de ampliação do estoque de terrenos públicos para atender àqueles segmentos da população que não têm condições de se inserir no mercado habitacional.

No cálculo deste déficit, por necessidade de incremento, foi considerado o comprometimento da renda das famílias com o aluguel ${ }^{80}$.

Tabela 4.3 - Domicílios alugados com condições básicas adequadas de habitação, de acordo com o comprometimento da renda da família principal com o pagamento do aluguel, por faixas de salários mínimos - Município de São José dos Campos - 2003.

\begin{tabular}{|c|c|c|c|}
\hline \multirow{2}{*}{$\begin{array}{c}\text { Renda } \\
\text { (Salários Mínimos) }\end{array}$} & \multicolumn{3}{|c|}{ Comprometimento de $30 \%$ da renda com aluguel } \\
\hline & Até $30 \%$ & Mais de $30 \%$ & TOTAL \\
\hline Até $3 \mathrm{SM}$ & 4.393 & 7.440 & 11.833 \\
\hline De 3 a 5 SM & 2.786 & 1.124 & 3.911 \\
\hline De 5 a 10 SM & 3.565 & 230 & 3.795 \\
\hline Mais de $10 \mathrm{SM}$ & 2.756 & 372 & 3.128 \\
\hline TOTAL & 13.501 & 9.167 & 22.667 \\
\hline \multicolumn{4}{|c|}{$\begin{array}{l}\text { Fonte: Pesquisa de instrumentação do planejamento urbano e avaliação do déficit habitacional em } \\
\text { São José dos Campos. NEPO/UNICAMP/PMSJC, } 2003 .\end{array}$} \\
\hline
\end{tabular}


A tabela 4.4 resume os componentes do déficit identificados:

Tabela 4.4 - Déficit estimado para o Município de São José dos Campos - 2003

\begin{tabular}{ccc}
\hline Déficit por reposição & Déficit por incremento & TOTAL \\
\hline 2.559 & 7.440 & 9.999 \\
\hline Fonte: Pesquisa de instrumentação do planejamento urbano e avaliação do déficit habitacional em \\
São José dos Campos. NEPO/UNICAMP/PMSJC, 2003.
\end{tabular}

Atualmente, a política para a habitação social do município continua a se limitar a algumas relocações de favelas para um loteamento denominado Jardim São José I e II, Zona Leste do município distante cerca de $10 \mathrm{~km}$ da Zona Central e implantado com recursos oriundos do Banco Interamericano de Desenvolvimento - BIRD.

Em parceria com o Governo Federal e o BIRD, desenvolveu-se o Projeto Jardim São José II. Foram construídas 453 unidades habitacionais para atender aos moradores das favelas Caparaó, Nova Detroit e Morro do Regaço, uma escola com quadra poliesportiva, uma Unidade Básica de Saúde, um Centro Comunitário, uma creche, além de toda a infra-estrutura de água, luz, esgoto, drenagem e asfalto.

A infra-estrutura implantada nesse projeto visou atender, não só essas famílias, mas também aquelas do entorno que, por morarem em loteamentos novos ou clandestinos ainda careciam desses serviços.

No Jardim São José II, como não foi possível realizar o regime de mutirão, pois as pessoas moravam longe da área, a participação da comunidade se deu através de um trabalho social e da comissão de moradores que acompanhou todas as obras e, junto com as assistentes sociais, mantinham as famílias informadas sobre o projeto. (fig. 4.3) 


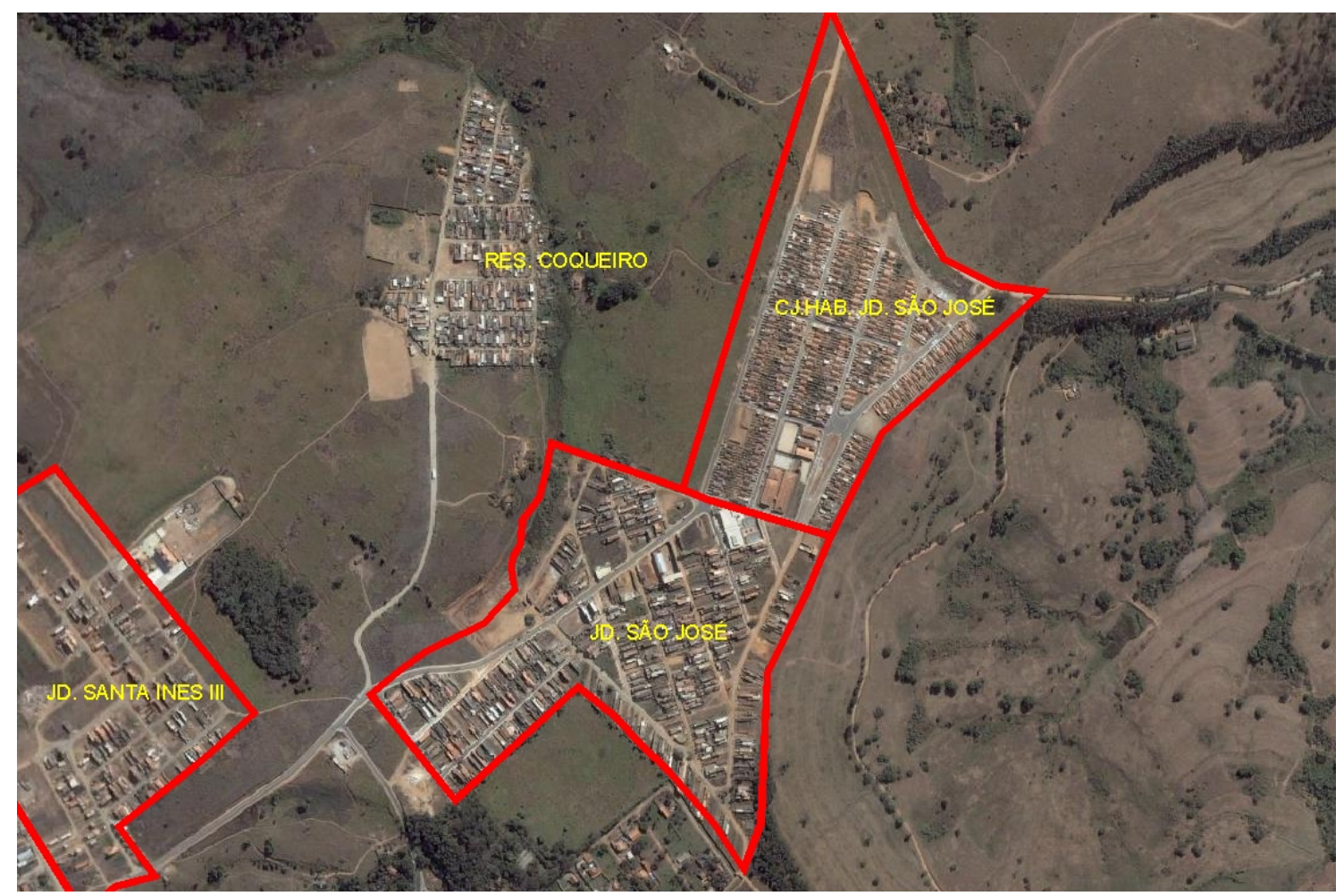

Figura 4.3 - Jardim São José I e II Fonte Google Earth, 2006.

A aplicação de instrumentos que incentivem a iniciativa privada à produção de habitação para extratos de média e baixa renda, como a regulamentação do empreendimento de habitação de interesse social, pode ser executado fora das ZEIS, o que pode vir a ser uma alternativa a ser explorada.

Verificamos que, até o início do ano 2000, não haviam sido viabilizados investimentos para a construção de novas unidades de interesse social e, para a regularização urbanística e fundiária dos 120 loteamentos clandestinos detectados antes da elaboração do PDDI, segundo informações da Secretaria de Habitação de São José dos Campos esse número deverá chegar a 200 no início do ano de 2007.

Verificamos ainda, que os principais projetos que não foram executados pela Secretaria de Planejamento referem-se: 1) à regulamentação das Operações Urbanas: instrumento pelo qual são permitidas mudanças urbanísticas, referentes à ocupação e uso do solo, em troca de investimentos em melhorias urbanas em determinados perímetros definidos em lei; 2) à utilização da Urbanização Consorciada: instrumento que 
permite parcerias entre a iniciativa privada e o poder público e 3) à criação do Fundo Municipal de Desenvolvimento Urbano: composto pelos recursos provenientes das operações interligadas, das operações urbanas, do orçamento municipal e de outras fontes públicas ou privadas, cujos recursos só poderão ser utilizados para projetos ou obras de urbanização, de infra-estrutura e de equipamentos urbanos sociais e coletivos.

Os instrumentos de gestão urbanística ficaram totalmente inviabilizados durante a elaboração do PDDI e esquecidos quando da promulgação da Lei de Zoneamento em 1997. Em ambos os momentos, foi devido à resistência por parte dos empresários do setor imobiliário que procuraram postergar o máximo possível a aplicação destes instrumentos, vinculando-os à regulamentação do Artigo 182, da Constituição Federal.

A única área destinada para abrigar uma operação urbana que constou na Lei de Zoneamento de 1997, foi a área do entorno do Parque da Cidade, contígua à Avenida Olivo Gomes, mas que não foi regulamentada até o presente.

O Plano Diretor de Desenvolvimento Integrado, aprovado em 1995, relacionou um grande número de projetos e programas para atender aos objetivos previamente estabelecidos para cada área de atuação, mas não definiu prioridades, custos e a origem dos recursos para viabilizá-los. Os projetos e programas realizados estão mais diretamente ligados à iniciativa de cada secretaria em fazer cumprir o Plano.

Destacamos por fim, a proposta de criação do Instituto de Planejamento Urbano do Município que tinha como objetivo: a) pensar a cidade a médio e longo prazo, b) definir as diretrizes de desenvolvimento do município e c) acompanhar a implantação dos programas e projetos relativos ao ordenamento do território. Além disso, o Instituto de Pesquisa e Planejamento Urbano de São José dos Campos - IPPSJC foi criado pela Lei Municipal $n^{0} 5680 / 00$ e não foi implantado até a presente data.

Para a implementação e gerenciamento do PDDI, foram propostas a criação do Instituto de Planejamento Urbano, voltado para a pesquisa e apoio das decisões e que 
visava ao desenvolvimento da urbanização e do Colegiado Municipal de Desenvolvimento Urbano $(\mathrm{CMDU})^{81}$, com a finalidade de garantir a participação da comunidade na consecução dos objetivos estabelecidos no PDDI.

\subsection{A regulamentação do PDDI de 1995}

Após a aprovação do PDDI de 1995 através da Lei Municipal Complementar $n^{0} 121$, foi elaborada uma pré-proposta de lei que visava regulamentar as diretrizes contidas nesse plano.

Essa pré-proposta foi apresentada e discutida em reuniões realizadas no Paço Municipal de São José dos Campos, durante o segundo semestre de 1995 e durante o ano de 1996, que continha em seus princípios, o estabelecimento de dois usos básicos: o residencial e o não residencial que apresentaremos a seguir de forma sintetizada.

Para o uso residencial, o objetivo principal foi a regulamentação da densidade demográfica: foram estabelecidos índices de densidade máxima por zona. Observou-se que, nas cidades brasileiras, o coeficiente de aproveitamento não regulava as densidades demográficas. Efetivamente, era a renda da população que definia a densidade e a opção pelo estabelecimento de densidades demográficas por zona conforme o grau de equipamento e infra-estrutura.

Para o uso não residencial foi estabelecido o coeficiente de aproveitamento único igual a um, podendo ser superado nas zonas onde houvesse infra-estrutura, por meio da outorga onerosa do direito de construir Solo Criado e, nas zonas com carência

\footnotetext{
${ }^{81} \mathrm{O}$ Colegiado Municipal de Desenvolvimento Urbano foi proposto com a finalidade de articular as ações desempenhadas pela Comissão de Zoneamento e pelos conselhos de representação da sociedade civil junto à prefeitura, tais como: Conselho Municipal do Meio Ambiente, Conselho Municipal do Patrimônio Histórico e Conselho Municipal da Habitação. O CMDU teria um caráter consultivo e deliberativo e seria composto por 21 membros, com direito a voto, distribuídos paritariamente da seguinte forma: 10 representantes do poder executivo municipal, 10 representantes de entidades da sociedade civil e um representante do chefe do executivo, que seria o presidente e que somente votará em caso de empate.
} 
de infra-estrutura, mediante aplicação do instrumento das Operações Interligadas. Este instrumento previa a análise urbanística do empreendimento a ser aprovado e o estabelecimento de contrapartida, para investimentos em habitação ou desenvolvimento urbano.

Em relação às zonas de uso, foi estabelecido que:

1) na zona onde deveria ser feito controle do adensamento que tratava da área central da cidade, na qual existiam condições satisfatórias de infraestrutura instalada, sua ocupação intensiva poderia provocar saturação, principalmente do sistema viário. Nesta zona o uso não residencial poderia superar o $C A=1$ até um limite de $C A=2$ mediante a aplicação de operações interligadas nas duas zonas com infra-estrutura e nas zonas com carência de infra-estrutura. Foi proposto que os empreendimentos habitacionais pudessem atingir uma densidade máxima de 600 hab/ha que foi fixado com base nos limites estabelecidos na zona a permitir o adensamento, cuja infra-estrutura era incompleta, mas a área era classificada como zona de expansão urbana. Nesta zona, foi fixada a densidade demográfica máxima de 400 hab/ha que correspondia a uma ocupação horizontal com lotes de $125 \mathrm{~m}^{2}$. Na contra-proposta ${ }^{82}$ apresentada pelos empresários, o coeficiente de aproveitamento seria quatro vezes a área do terreno.

2) na zona onde deveria ser incentivado o adensamento que se caracterizava como uma área onde houvesse condição satisfatória de infra-estrutura, porém com baixa intensidade de aproveitamento. Nesta zona, buscava-se estimular a ocupação prevendo a densidade máxima de 800 hab/ha para o uso residencial e, para o uso não residencial, o coeficiente máximo

82 Os representantes do setor construtivo e imobiliário que participavam das reuniões para regulamentação do PDDI de 1995 apresentaram um parecer com sugestões para alterações da pré-proposta elaborada pela Administração Municipal denominada de "Contra-Proposta". 
poderia chegar a quatro vezes a área de terreno, mediante outorga onerosa do direito de construir. Nos lotes vazios ou subutilizados com área acima de $20 \mathrm{mil} \mathrm{m}^{2}$, seria aplicado o dispositivo constitucional do IPTU progressivo no tempo para evitar sua retenção especulativa e incentivar sua ocupação. Na contra-proposta foi sugerido um coeficiente igual a seis. Nesta zona, a prefeitura poderia convocar, por edital ou receber proposta de proprietários de terrenos, que tivessem interesse em participar de empreendimentos de Habitação de Interesse Social e/ou de Condomínios Empresariais, sendo utilizado como instrumento urbanístico a Urbanização Consorciada. Para tanto, seria necessária a avaliação do interesse público pelo Planejamento Urbano do Município e aprovado pelo Colegiado Municipal do Desenvolvimento Urbano.

3) na zona a restringir o adensamento se localizava no sopé da Serra da Mantiqueira caracterizada como Zona de Preservação das condições ambientais, sobretudo pela fragilidade do solo. Nesta zona foi proposto que se limitasse a densidade habitacional através da permissão de ocupação por lotes mínimos de 2 mil m², introduzindo-se uma cota de terreno de $500 \mathrm{~m}^{2}$ por unidade residencial, a fim de incentivar a implantação de conjuntos condominiais. A contra-proposta propunha que não fosse fixada nenhuma densidade para toda a Região Norte e que não fosse limitado o tamanho máximo do lote e fossem mantidas as exigências da Lei Municipal $n^{\circ} 3721 / 90$.

Quanto ao controle urbanístico do uso não residencial, este previa uma transformação dos mecanismos de controle, porém não ia além de um zoneamento convencional restrito. A disseminação dos usos por toda a cidade, tendência recente constatada nas grandes cidades, entra em conflito com a rigidez da legislação atual. 
Nesse sentido previa-se uma flexibilização da localização das atividades, evitando o aumento das exigências burocráticas para regular criteriosamente usos incômodos.

Dentro desse quadro os usos não residenciais foram classificados conforme seu nível de compatibilidade com o uso residencial. Assim, foram estabelecidos três tipos nessa classificação: compatível, incompatível com o uso residencial e industrial.

1) Os usos não residenciais compatíveis com o uso residencial, poderiam ser instalados em qualquer lote na área urbana ou de expansão urbana, com exceção das Áreas de Proteção Ambiental e das Zonas Especiais que poderiam ter maiores restrições no uso do solo. Seriam admitidos no mesmo lote e/ou na mesma edificação, usos residenciais com usos não residenciais compatíveis e, também, com os incompatíveis relacionados nessa lei e classificados no Nível $A$, relativos as indústrias de baixo potencial de incomodidade.

2) O uso industrial estaria sujeito ao controle especial para sua instalação, por meio da análise do instrumental já utilizado nas leis anteriores, denominado Memorial de Caracterização do Empreendimento - MCE, que definiria o nível de incompatibilidade das atividades, de acordo com a Classificação dos Níveis das Fontes de Poluição e segundo parâmetros ambientais;

3) Os usos não residenciais incompatíveis com o uso residencial, em função de seus impactos negativos ambientais, urbanísticos e de circulação, estariam sujeitos a controle especial. Seria estabelecido o nível de incompatibilidade por meio dos impactos negativos tais como: ruído, emissão de efluentes (materiais particulados, odores, gases e vapor), periculosidade, exigência sanitária, geração de tráfego e outros. 
De acordo com o nível de incompatibilidade, seria verificada a possibilidade de instalação do uso pretendido, por meio dos parâmetros estabelecidos por uma Análise de Localização ${ }^{83}$.

Com a leitura das atas do PDDI constatamos que havia uma divergência entre os elaboradores do Plano e os representantes da sociedade civil. Considerando as diversas intervenções dos participantes da Comissão de Zoneamento, delinearam-se alguns aspectos e impasses: 1) a dificuldade no que se refere aos aspectos fundiários de se conseguir aplicar a lei proposta devido à forte pressão imobiliária representada pelos empresários e 2) a falta de implementação dos instrumentos urbanísticos.

Em relação aos instrumentos urbanísticos propostos no PDDI de 1995, estavam previstos os referentes à operação urbana ${ }^{84}$, operação interligada, urbanização consorciada $^{85}$, ao imposto progressivo no tempo, e ao parcelamento ou edificação compulsória. Por meio destes instrumentos, propôs-se estabelecer trocas com a iniciativa privada, a exemplo de habitações de interesse social ou obras de infra-estrutura, como também controlar o uso especulativo da terra, por meio do IPTU progressivo no tempo. Por meio das Zonas Especiais de Interesse Social (ZEIS), promover a regularização urbanística de áreas de favela e loteamentos clandestinos de interesse social. Esses instrumentos foram definidos conceitualmente no PDDI, entretanto, sua regulamentação ficou prevista para uma fase posterior, após discussão ampla com todos os segmentos da sociedade.

Também constam das diretrizes do PDDI de 1995, a utilização dos instrumentos de operação urbana e operação interligada para produção do espaço urbano, conjuntamente com os agentes públicos e privados.

\footnotetext{
${ }^{83} \mathrm{~A}$ análise de localização, de acordo com seu nível de incompatibilidade, deveria ser verificada a possibilidade de instalação do uso pretendido, por meio dos parâmetros pré-estabelecidos pela Análise de Localização a qual estará sujeito.Os lotes vazios eram computados como uso não residencial.Para as edificações destinadas ao uso misto, prevaleceria a analise de localização para a atividade no nível mais restritivo.

${ }^{84}$ Instrumento pelo qual é permitida mudanças urbanísticas referentes a ocupação e uso do solo em troca de investimentos em melhorias urbanas em determinados perímetros definidos em lei.

${ }^{85}$ Instrumento que permite parcerias entre a iniciativa privada e o poder público.
} 
Durante a elaboração da pré-proposta de Lei de Zoneamento, em 1996, houve dúvida quanto ao real objetivo das operações interligadas: se este instrumento tratava simplesmente da provisão de recursos para investimentos urbanos, ou principalmente, a flexibilização pontual da legislação de zoneamento existente, colocando em risco as poucas salvaguardas da qualidade ambiental urbana, materializadas no zoneamento existente.

Ocorreu que vários projetos apresentados não foram executados, entre eles: a) regulamentação das Operações Urbanas - instrumento pelo qual são permitidas mudanças urbanísticas, referentes à ocupação e ao uso do solo, em troca de investimentos em melhorias urbanas em determinados perímetros definidos em lei; b) utilização da Urbanização Consorciada - instrumento que permite parcerias entre a iniciativa privada e o poder público e a criação do Fundo Municipal de Desenvolvimento Urbano composto pelos recursos provenientes das operações interligadas, das operações urbanas, do orçamento municipal e de outras fontes públicas ou privadas, cujos recursos só poderiam ser utilizados para projetos ou obras de urbanização, de infra-estrutura e de equipamentos urbanos sociais e coletivos.

A não regulamentação de instrumentos e mecanismos que poderiam diminuir a ação especulativa com a terra urbana tem dificultado a formação de um estoque de terrenos públicos em São José dos Campos.

Dentre os inúmeros projetos apresentados no PDDI de 1995 destacamos a proposta para a criação do Fundo Municipal de Desenvolvimento Urbano ${ }^{86}$. A consciência da dificuldade de aplicação dos instrumentos via Plano Diretor é verificada quando o grupo do segmento empresarial local apresentou uma contra-proposta à lei de zoneamento apresentada pelo grupo da prefeitura.

\footnotetext{
${ }^{86}$ Composto pelos recursos provenientes das operações interligadas, das operações urbanas, do orçamento municipal e de outras fontes públicas ou privadas, cujos recursos só poderão ser utilizados para projetos ou obras de urbanização, de infra-estrutura e de equipamentos urbanos sociais e coletivos.
} 
$\mathrm{Na}$ ata da $39^{\mathrm{a}}$ Reunião da Comissão de Zoneamento verificamos que a preocupação dos elaboradores da Lei de Zoneamento (a prefeitura), em relação à adoção de instrumentos urbanísticos para captação de recursos, foi em virtude da constatação dos escassos recursos públicos destinados à redução de desigualdades existentes em São José dos Campos.

A legislação proposta previa mecanismos de parceria com a iniciativa privada para obtenção de parte dos investimentos que se fazem necessários para o desenvolvimento da cidade. Acreditavam que, com a aplicação dessa legislação, por meio de seus instrumentos, conseguiriam a otimização e a racionalização dos investimentos já realizados e da infra-estrutura existente. O coeficiente único proposto a ser adotado em toda a zona urbana foi considerado pelos empresários locais como sendo ideológico. Porém, esse coeficiente significava a busca de recursos em parceria com a iniciativa privada para a diminuição das desigualdades da cidade e sua homogeneização em termos de qualidade de vida para a população.

De maneira geral, os instrumentos urbanísticos apresentados eram inovadores e advindos de um movimento internacional ${ }^{87}$ e esses surgiram da necessidade de se mudar a forma de dirigir o crescimento das cidades e, também, para incentivar a criação de fóruns que efetivamente contemplem a gestão dessas matérias.

Destacamos também a sugestão feita pela contra-proposta quanto à composição do Colegiado Municipal de Desenvolvimento Urbano ${ }^{88}$ que deveria ser

\footnotetext{
87 Naquele período estavam sendo discutidos os preceitos contemporâneos e recentes do urbanismo, que na Conferência Mundial Habitat II de 1996, em Istambul, foram consolidados em um documento.

${ }^{88}$ O Colegiado Municipal de Desenvolvimento Urbano - CMDU - tinha como função articular as ações desempenhadas pela Comissão de Zoneamento e pelos conselhos atualmente existentes de representação da sociedade civil junto à Prefeitura, como: Conselho Municipal do Meio Ambiente, Conselho Municipal do Patrimônio Histórico e Conselho Municipal de Habitação. O CMDU terá caráter consultivo e deliberativo, nos assuntos citados nesta pré-proposta e será composto por 21 membros, com direito a voto, distribuídos paritariamente da seguinte forma: 10 representantes de poder executivo municipal, 10 representantes de entidades da sociedade civil e um representante do chefe do executivo, que o presidirá e que somente votará em caso de empate.
} 
composto por $1 / 3$ com membros do Poder Público e 2/3 com membros da sociedade civil organizada, com critérios para indicação das entidades (representatividade, serviços prestados, tempo de experiência, etc.).

Salienta-se que o condomínio empresarial, uma modalidade de uso que seria criada e permitida em terreno com área não superior a $40 \mathrm{mil} \mathrm{m}^{2}$ e exigindo do empreendedor, caso a área do terreno fosse superior a 10 mil $\mathrm{m}^{2}$, a doação para o poder público de 10\% para área verde e de 5\% para área institucional, proporcional à área total do terreno, devendo, as áreas públicas serem localizadas fora do condomínio e com frente para a via pública. A contra-proposta sugeriu que não fosse limitada a área máxima para o empreendimento, que a área verde deveria ficar dentro do condomínio e a área institucional ficasse fora de condomínio.

A atenção do setor imobiliário para a legislação urbanística tem sido cada vez mais atuante e vigilante. Segundo esse setor, a maior parte dos instrumentos apresentados no Plano Diretor de 1995 são limitadores da atividade imobiliária e as disposições mais criticadas do Plano, foram: a) o coeficiente único igual a uma vez a área do terreno e b) a venda do direito de construir foi a que teve menos aceitação. Nessas reuniões ficou clara a oposição aos instrumentos urbanísticos por parte do segmento empresarial participante e esse teve o apoio da AEASJC e de alguns juristas que defendiam a ilegalidade desses instrumentos.

Além do coeficiente único, durante as reuniões da Comissão de Zoneamento, o Solo Criado foi considerado pelos participantes como o mais polêmico. Para eles, o instrumento poderia vir a desestabilizar o mercado imobiliário e encarecer os imóveis. Consideraram ainda que, com a aplicação desse instrumento urbanístico, poderia haver uma evasão da construção civil para os municípios vizinhos, assim como já vinha acontecendo com as indústrias que estavam migrando para Jacareí e Caçapava, devido ao baixo custo dos terrenos e incentivos fiscais que essas cidades vinham oferecendo. 
Enfim, alegavam que esse instrumento urbanístico, o Solo Criado, viria a sobrecarregar o consumidor final.

Na verdade, o Solo Criado foi declarado inconstitucional quando apresentado no Plano Diretor de São Paulo e muito dos instrumentos apresentados foram enfraquecidos por argumentos de ordem legal.

Em relação às Operações Interligadas e Urbanas, os participantes não se manifestaram desfavoráveis a esses instrumentos. Porém, podemos verificar pela leitura das atas dessas reuniões que o setor imobiliário não tinha interesse em regulamentar as Operações Interligadas, pois o coeficiente que viria a ser adotado na Lei de Uso e Ocupação do Solo, aprovada em 1997, colocava o índice de aproveitamento igual a três vezes em quase toda a zona urbana, tornando-a desnecessária e inviável automaticamente.

Quanto aos instrumentos do IPTU progressivo no tempo, a Edificação Compulsória e a Desapropriação, mediante pagamento com Títulos da Dívida Pública, alegaram que esses para serem aplicados sucessivamente como penalidades aos imóveis ociosos, ainda dependiam de regulamentação federal conforme exigência do Artigo $182 \S 4^{\circ}$ da Constituição Federal de 1988.

Em agosto de 1996, ocorreu o Seminário Internacional "Instrumentos de Manejo do Solo Urbano: experiências e possibilidades".

O objetivo central desse seminário foi o de promover a discussão da recente experiência dos municípios brasileiros em propor e aplicar novos instrumentos urbanísticos para o manejo do solo urbano. Esse seminário também visava avaliar a eficácia no atendimento dos objetivos e estratégias propostas e sua influência sobre os mercados fundiários e imobiliários urbanos.

No seminário, foram relatadas as experiências das cidades de Natal, Belo Horizonte, Porto Alegre, Recife e São José dos Campos que apresentaram grandes avanços e muitos limites na reformulação do Planejamento Urbano. Destacam-se as 
ZEIS que se constituíram em um instrumento redistributivo que deu certo nessas cidades, enquanto que, o Solo Criado se apresentou como um instrumento limitado, face aos interesses contrários que suscita. Mas foi a criação de fóruns de negociação de comissões de zoneamento ou de conselhos de desenvolvimento, que os destinos da cidade poderiam ser debatidos e deliberados o que, sem dúvida, foi um dos grandes avanços constatados nas exposições dos planos de cada cidade ${ }^{89}$.

Para Gottdiener (1996),

A questão do controle, gestão ou desregulação do uso do solo no planejamento urbano deve ser localizada, em primeiro lugar, na história do desenvolvimento de uma sociedade e, em seguida, dentro de um quadro político-econômico antes de ser analisada com clareza. Esse é o caso da regulação do solo, porque atualmente os economistas não têm um consenso unificado de como tratá-la como regulá-la e como tratá-la como recurso social. Conseqüentemente, a assim chamada "questão fundiária" é sempre uma questão política.

As reuniões para a regulamentação do PDDI de 1995 se estenderam até o final de 1996 e a regulamentação do Plano Diretor de 1995 não foi encaminhada à Câmara Municipal.

O final da década de 90 trouxe para São José dos Campos problemas relacionados ao aumento do desemprego, das desigualdades e da exclusão social.

A primeira proposta de regularização do PDDI de 1995 teve como objetivo principal diminuir as iniqüidades sociais através de um zoneamento elaborado em seus princípios pela articulação da ação dos agentes públicos e privados por meio de parcerias para se obter recursos para financiamento de equipamentos e infra-estrutura urbana, porém, em 1997, uma nova administração assumiu a prefeitura e essa proposta foi abandonada.

Em 1997, com o argumento de diminuir esses problemas foi estabelecida, pela administração municipal, a necessidade de ser proposta uma nova lei de

${ }^{89} \mathrm{Na}$ ata da $42^{\mathrm{a}}$ reunião da Comissão de Zoneamento de São José dos Campos verificamos que foi colocado aos presentes que "[...] a idéia de colegiado de Desenvolvimento Urbano preveria que por meio desse dar-se-ia a articulação dos demais conselhos e fundos, sendo que esse colegiado seria o responsável pela coordenação das ações e recursos da administração". 
parcelamento e de uso e ocupação do solo que procurasse flexibilizar ao máximo o uso e a ocupação do território no município.

Contrária às diretrizes da pré-proposta de lei de regulamentação de 1996, foi proposta uma nova lei de uso e ocupação do solo e o território de São José dos Campos foi dividido em várias zonas mistas que permitiam a instalação de indústrias de pequeno e médio porte, com o intuito de atrair o capital industrial e, principalmente, de serem atendidas as sugestões feitas pela contra-proposta dos empresários de São José dos Campos.

Nessa nova proposta não se propunha um zoneamento por densidade e um coeficiente único de 1 para todo o território municipal; a nova lei propôs coeficientes elevados e variados.

Nas zonas mistas, o coeficiente a ser utilizado seria de 3 vezes a área do terreno, nas Zonas Residenciais seria de 1,3 e para a Zona Central aplicar-se-ia o coeficiente de 4 vezes. Esse último, foi aplicado com o objetivo de atrair para o Centro investimentos para construção do uso residencial multifamiliar. No entanto, o que podemos observar é que, até hoje, não ocorreu nenhum investimento dessa categoria de uso nessa região.

Seus formuladores também acreditavam que, com coeficientes elevados, o setor privado iria investir mais nas diversas regiões do município e as indústrias voltariam a se implantar no município. Essa lei de zoneamento foi aprovada em 15 de dezembro de 1997 e está vigente até a presente data.

Durante a elaboração da lei de zoneamento, em 1997, a "nova" administração levantou a questão sobre o real objetivo das operações interligadas quanto a provisão de recursos para investimentos urbanos.

No decorrer de seus dez anos, a Lei Complementar Municipal $n^{\circ} 165 / 97$ sofreu inúmeras alterações, assim como as suas anteriores, de 1970, 1980 e 1990 que continuam a ser feita com o objetivo de prever e respaldar novas situações legais, não 
previstas ou não permitidas, para se ajustarem às novas demandas provenientes das mais diversas origens. Continuam a ser propostas alterações no zoneamento de uma zona, criação de novas zonas de uso, restrição ou incentivo à verticalização, incremento ou redução de parâmetros de ocupação do solo.

No período de vigência dessa lei também pudemos verificar que houve três leis de anistia para regularização das construções, em 1998, 1999 e a última, feita através da Lei Municipal $n^{\circ} 271 / 03$ que continua sem prazo para término. Segundo levantamento da Divisão de Projetos da Secretaria de Planejamento Urbano existem 1.800 processos para a legalização de construções a serem analisados até julho de 2007.

Cabe a pergunta: Para que uma lei que regulamenta o uso e ocupação do solo enquanto existem outras para legalizar o não cumprimento dessa?

\subsection{O Estatuto da Cidade}

Existem, hoje, duas leis nacionais que se destacam na qualidade de condicionantes do Plano Diretor e das demais normas urbanísticas locais, são elas: 1) Lei Federal $n^{\circ}$ 6766/79: destacamos entre seus dispositivos, o artigo 40, "o poder de o Município assumir a regularização do loteamento irregular para evitar lesão a seus padrões de desenvolvimento urbano e na defesa dos direitos dos adquirentes dos lotes"; e 2) Lei Federal $n^{0} 10.257 / 01$ - Estatuto da Cidade que deve ser considerado por inteiro na elaboração do Plano Diretor.

A Lei Federal $n^{0} 6766 / 79$, foi a primeira lei nacional que previu disposições penais para loteadores, oficiais de registro de imóveis e demais profissionais envolvidos no processo de aprovação, registro e execução de parcelamento e fixa regras mínimas de cunho urbanístico, estabelecendo em seu artigo $1^{\circ}$ que, os Estados, o Distrito Federal 
e os Municípios poderão estabelecer normas complementares relativas ao parcelamento do solo municipal para adequar o previsto nesta lei às peculiaridades regionais e locais.

Enquanto que a primeira lei, aprovada em 19 de fevereiro de 1979, vem há muitos anos regendo o parcelamento do solo para fins urbanos no Brasil, a segunda Lei Federal, o Estatuto da Cidade, mais recente, entende que o desenvolvimento urbano presidido pelo município deve ocorrer em conformidade com as diretrizes nacionais, assegurando a homogeneidade mínima que sintetiza o interesse nacional sobre a questão urbana.

O Estatuto da Cidade é um marco na história da política urbana brasileira. A Lei Federal $n^{0}$ 10.257, aprovada em 10 de julho de 2001 é complementada pela Medida Provisória $\mathrm{n}^{0} 2.200$ de 04 de setembro de 2001 (concessão de uso especial para imóveis públicos) encarrega-se, pela Constituição Federal, de definir o que significa cumprir a função social da cidade e da propriedade urbana. O estatuto delega esta tarefa aos municípios, oferecendo para as cidades um conjunto inovador de instrumentos de intervenção sobre seus territórios.

Além de viabilizar o uso de instrumentos urbanísticos para a execução das políticas de planejamento, amplia as condições da sociedade realizar uma gestão mais democrática e municia os órgãos das administrações municipais com leis, diretrizes e estruturas técnicas mais modernas e adequadas. O Estatuto da Cidade, antes de tudo, procura orientar o legislador local e até mesmo condiciona a validade das normas municipais relacionadas ao tema.

Essa lei propõe, entre outras, algumas regras a serem observadas na condução do desenvolvimento urbano; por vezes, aprofunda assuntos previstos na Carta Constitucional, mas não soluciona diretamente tais questões: aponta caminhos e possibilidades. No entanto, a intenção do Estatuto da Cidade não é a de definir de modo direto e imediato o desenvolvimento urbano. 
As inovações contidas no Estatuto situam-se em três campos: um conjunto de novos instrumentos de natureza urbanística voltado para induzir - mais do que normatizar - as formas de uso e ocupação do solo; uma nova estratégia de gestão que incorpora a idéia de participação direta do cidadão em processo decisórios sobre o destino da cidade e a ampliação das possibilidades de regularização das posses urbanas, até hoje situadas na ambígua fronteira entre o legal e o ilegal.

No primeiro conjunto - dos novos instrumentos urbanísticos - a evidente interação entre regulação urbana e a lógica de formação de preços no mercado imobiliário é enfrentada através de dispositivos que procuram coibir a retenção especulativa de terrenos e de instrumentos que consagram a separação entre o direito de propriedade e potencial construtivo dos terrenos, atribuído pela legislação urbana. Com o estatuto, as áreas vazias ou subutilizadas situadas em áreas dotadas de infra-estrutura estão sujeitas ao pagamento de IPTU progressivo no tempo e à edificação e parcelamento compulsório, de acordo com a destinação prevista para a região pelo Plano Diretor.

Ainda sobre os instrumentos urbanísticos propostos no Estatuto da Cidade, destacamos o Solo Criado, cuja idéia é: se as potencialidades dos diferentes terrenos urbanos devem ser distintas em função da política urbana (áreas que em função da infraestrutura instalada devem ser adensadas, áreas que não podem ser intensamente ocupadas por representarem alto potencial de risco - de desabamento ou alagamento, por exemplo), não é justo que os proprietários sejam penalizados ou beneficiados individualmente por esta condição, que independeu totalmente de sua ação sobre o terreno.

Desta forma, separa-se um direito básico que todos os lotes urbanos devem possuir dos potenciais definidos pela política urbana. Não há dúvida quanto à adequação em configurá-los como um conjunto normativo que tem a função de intermediar a Constituição da República e o direito urbanístico local. 
Pela primeira vez na história do urbanismo brasileiro, há uma regulação federal para a política urbana que se pratica no país, definindo uma concepção de intervenção no território que se afasta da ficção tecnocrática dos velhos Planos Diretores de Desenvolvimento Integrado, que tudo prometiam, mas nenhum instrumento possuía para induzir a implementação do modelo idealizado proposto.

O Estatuto da Cidade presta um valioso serviço para a evolução do direito urbanístico quando propõe instrumentos urbanísticos que objetivam diminuir as iniqüidades sociais existentes nos municípios brasileiros.

Na verdade, parte dos instrumentos previstos já era acessível aos municípios e até utilizado por alguns, como a outorga onerosa, a transferência do direito de construir, a operação consorciada e o estudo de impacto de vizinhança. No caso específico de São José dos Campos, em 1996, esses instrumentos fundiários foram propostos na préproposta de regulamentação do PDDI de 1996.

Segundo Malta Filho ${ }^{90}$,

[...] é a comunidade, em última instância, que deve decidir para onde a cidade deve crescer, com quais atividades econômicas, onde o zoneamento tem de ser mais rígido, onde tem de ser mais flexível e é a própria cidade que deve zelar para que o zoneamento, e as ferramentas de política urbana - como o IPTU progressivo e o solo criado, por exemplo - façam parte do plano diretor e sejam instrumentos urbanísticos de indução para que as políticas de planejamento urbano não sofram perda de continuidade.

Ao refletirmos sobre a colocação feita pelo autor, podemos dizer que a maioria dos municípios brasileiros e, em particular, São José dos Campos, ainda não se deu conta do grande alcance do Estatuto da Cidade e poucas prefeituras realmente o incorporam à prática política e administrativa.

Muitas cidades e, no caso específico de São José dos Campos, parecem ter adotado uma atitude passiva diante desse documento, aproveitando pouco o seu

\footnotetext{
90 In Entrevista concedida para a Revista Technè - Edição 98 - Ano 13 - Editora Pini, maio de 2005, p. 22.
} 
potencial de intervenção. Sem dúvida há uma razão de ordem prática, já que o estatuto é relativamente recente e há cidades que estão ainda se aparelhando para absorvê-lo.

Não podemos esquecer que o estatuto tem um alcance praticamente nacional e, como lei federal, obriga todas as cidades brasileiras com mais de 20 mil habitantes a ter um Plano Diretor, envolvendo em seu contexto mais de $80 \%$ da população brasileira que hoje vive nas cidades.

Os municípios precisam contar com, no mínimo, um corpo técnico profissional para detalhar e pôr em movimento um Plano Diretor, embora este tenha que ser concebido e aprovado pelo conjunto da cidade.

A inovação da Lei Federal $n^{0} 10.257 / 01$ se deve ao fato dessa contemplar diretrizes nacionais para o uso dos instrumentos urbanísticos, além de afastar de vez certos questionamentos que rondavam sua aplicação.

De modo geral, essas indagações traziam uma certa insegurança para os formuladores da legislação urbanística quando esses lançavam a suspeita de que esse ou aquele instrumento deveria ser introduzido por lei federal, por tocar o direito de propriedade.

É fato, no entanto, que o parcelamento, a edificação ou a utilização compulsórios, o IPTU progressivo no tempo e a desapropriação mediante pagamento em títulos da dívida pública tiveram que aguardar a vigência do Estatuto da Cidade.

Em relação ao coeficiente de aproveitamento do imóvel, o Estatuto da Cidade, propõe que esse pode ser ampliado além do valor básico fixado em lei, competindo ao município, dentro das condições legais, analisar caso a caso se convém admitir sua aplicação ou não, mediante contrapartida do interessado.

O que pudemos verificar é que os principais obstáculos têm sido mesmo os de ordem jurídica e política-econômica. Boa parte das cidades não decidiu ainda se as resoluções do Plano Diretor devem ser leis imediatamente aplicáveis ou apenas diretrizes 
com poder meramente indicativo - como é tradicional na história dos planos diretores de São José dos Campos e do Brasil.

O Estatuto da Cidade é, sim, um dispositivo constitucional na medida em que regulamentou alguns artigos da Constituição Federal de 1988 referentes à política urbana. A força de lei do Estatuto é, portanto, muito grande assim como o amparo dado pelo estatuto ao conjunto de normas a ele subordinado - o Plano Diretor.

Mesmo os planos diretores sem força de lei, certamente conseguirão ser implantados com maior facilidade, por estarem apoiados pelo estatuto das cidades. Não podemos esquecer que o papel dos planejadores urbanos precisa também ser incisivo e contar com a vontade política, pois o estatuto não vai ser implantado sozinho.

Destacamos também do Estatuto da Cidade a previsão de uma gestão mais democrática, que por meio de debates, audiências e consultas públicas terão de ser providas por órgãos colegiados de política pública.

$\mathrm{Na}$ verdade, ele aproxima a política urbana dos moradores em mais de um aspecto. Prevê estudos de impacto de vizinhança para facilitar a vida dos moradores próximos a bares, boates, templos religiosos ou indústrias que terão mais força para restabelecer a lei do silêncio. Audiências públicas também estão previstas para análise de projetos que possam causar impacto ambiental ou de outro tipo. Enfim, os moradores de uma cidade podem se manifestar livremente e vetar ou acolher a nova instalação nas áreas próximas a suas residências.

Partindo do pressuposto de que a população se interessa pela política urbana, embora nem sempre tenham consciência disso, cabe aos próprios cidadãos definir o que é melhor para a sua cidade, não se esquecendo de que, dentro de parâmetros técnicos, é preciso que a administração municipal disponha de números e projeções consistentes sobre o uso do solo e os efeitos do zoneamento possam vir causar na cidade. E é a própria cidade que deve zelar para que o zoneamento e as ferramentas de política urbana - como o IPTU progressivo e o solo criado, por exemplo - 
façam parte do Plano Diretor e sejam realmente de indução para que o plano não sofra perda de continuidade.

O terceiro conjunto de instrumentos trata da regularização fundiária de áreas ocupadas - e não tituladas - da cidade.

A maior parte das cidades brasileiras é constituída por assentamentos irregulares, ilegais ou clandestinos, que contrariam de alguma maneira as formas legais de urbanização. Parte destes assentamentos é composta por propriedades públicas ou privadas abandonadas ou não utilizadas.

Para enfrentar esta questão, o Estatuto aprovado pelo Congresso Nacional previa a regulamentação do usucapião (inclusive coletivo) para regularizar a posse de terrenos privados e a concessão do direito real de uso para imóveis públicos ocupados por posseiros.

Ao sancionar a lei, o então Presidente da República Fernando Henrique Cardoso vetou todos os artigos referentes à concessão, permanecendo apenas o usucapião. Com essa medida, a ocupação de imóveis públicos - que são, na verdade, a maior parte das terras onde se encontram as favelas em nossas cidades - ainda não estão sendo tratadas por lei federal.

Por fim, o Estatuto da Cidade trouxe uma nova possibilidade de prática, apresentando uma nova concepção de planejamento urbano, mas depende fundamentalmente do uso que dele fizerem as cidades. Boa parte dos instrumentos, sobretudo urbanísticos, dependem dos Planos Diretores; outros da legislação municipal específica que aplique o dispositivo na cidade.

Os cidadãos têm, entretanto, o direito e o dever de exigir que seus governantes encarem o desafio de intervir, concretamente, sobre o território na perspectiva de construir uma cidade com melhor qualidade de vida para sua população. 


\subsection{Análises e tendências de ocupação do território}

A proposta deste trabalho foi compreender o processo de planejamento e de urbanização de São José dos Campos no período entre 1950 a 2000. Utilizamos como eixo e objeto deste estudo a legislação urbanística produzida para esse município e a região do Vale do Paraíba.

Até aqui, apresentamos algumas considerações gerais sobre a rede urbana paulista, a conformação do espaço urbano-regional e a construção do pólo regional de São José dos Campos, o histórico da evolução urbana e a legislação urbanística municipal e regional no período entre 1950 a 2000. Todo o trabalho desenvolvido teve como objetivo evidenciar que existiram inúmeras intervenções no espaço urbano desse município por meio da legislação, que teve como foco o crescimento econômico do município e de sua região.

Após o levantamento e sistematização dos temas aqui abordados, ressaltamos que a presença dos aspectos regionais foi apresentada como "pano de fundo" desta dissertação, uma vez que a questão é a inserção do espaço regional que produziu efeito no território específico de São José dos Campos.

Numa abordagem preliminar, verificamos que a legislação urbanística produzida em São José dos Campos, tanto municipal como regional, provocou a ocupação do território intramunicipal para uma segregação espacial. Esta segregação espacial é muito clara quando observamos o território no Mapa de Vulnerabilidade Social Paulista ${ }^{91}$.

\footnotetext{
${ }^{91}$ O Índice Paulista de Vulnerabilidade Social - IPVS foi criado em 2000, para ser um instrumento de avaliação das políticas públicas e, também, ser um indicador para o conhecimento mais detalhado das condições de vida dos municípios do Estado de São Paulo, com o objetivo de identificar e localizar espacialmente as áreas que abrigam os segmentos populacionais mais vulneráveis à pobreza. Construído a partir dos dados do Censo Demográfico de 2000, o IPVS consiste em uma tipologia derivada da combinação entre duas dimensões, socioeconômica e demográfica, que classifica as áreas geográficas intramunicipais em grupos distintos de vulnerabilidade social. A dimensão socioeconômica é composta pela renda apropriada das famílias e o poder de geração da mesma por seus membros, enquanto a demográfica relaciona-se ao ciclo de vida familiar.
} 


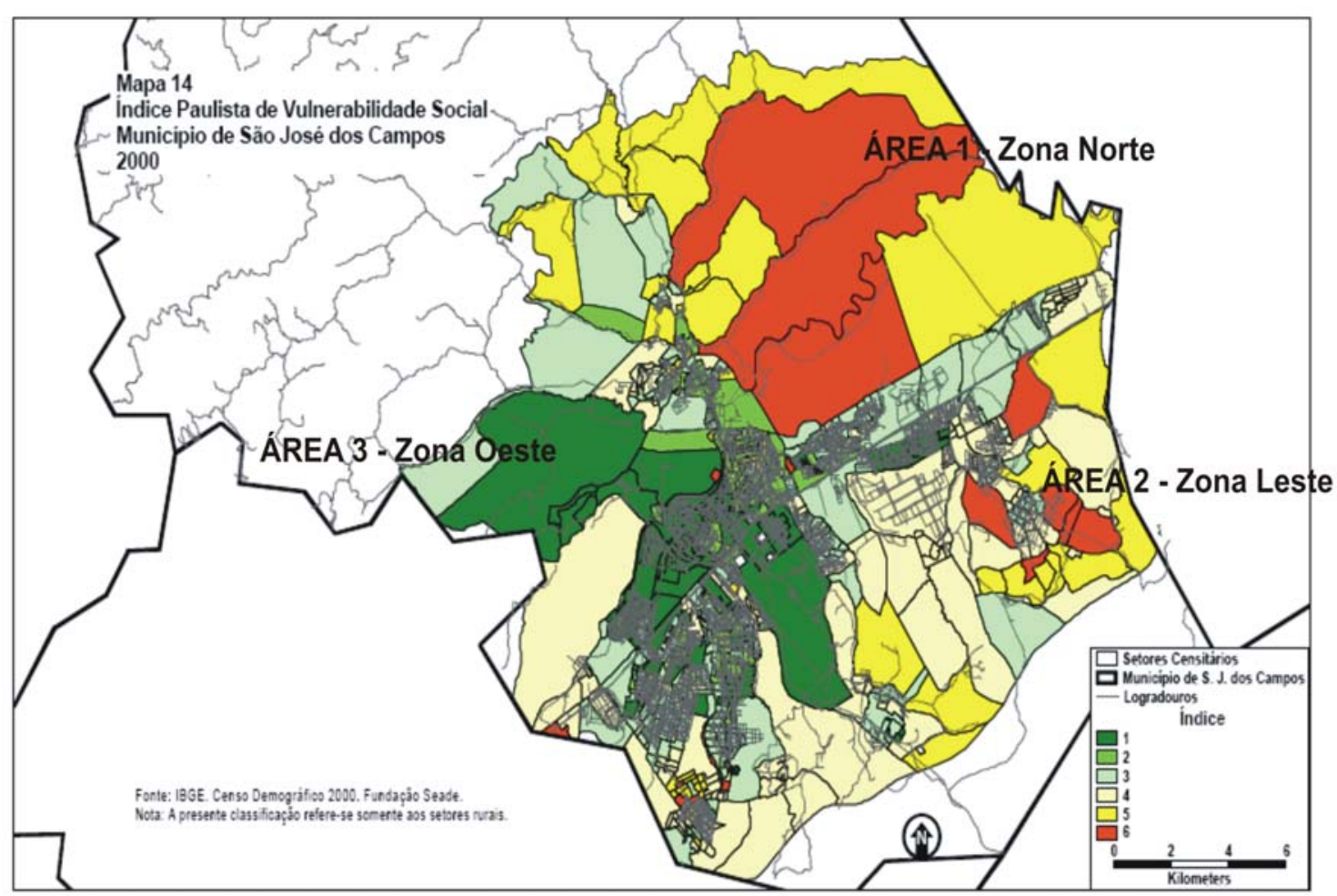

Figura 4.4 - Mapa de Vulnerabilidade Social Paulista

Fonte: IBGE - Censo Demográfico 2000. Fundação Seade.

O mapa de vulnerabilidade social, (Fig. 4.4), evidencia que o território de São José dos Campos está dividido ao Oeste e Sul por uma população mais favorecida que incentiva o comércio no entorno, escolas e condomínio de alto padrão. A Norte e Leste, a situação é inversa, pois há intensa ocupação de loteamentos clandestinos e no entorno há um comércio precário, e existem centros comunitários para esporte e lazer.

No caso de São José dos Campos, o processo de produção do espaço, dentro de um contexto de relações capitalistas, determina a forma como ocorre a ocupação espacial urbana. Nesse sentido, as cidades são produtos das contradições inerentes a esse processo de produção em determinado período histórico. Apresentam com freqüência diferenciações no uso do solo que constitui o processo de segregação sócio-espacial.

Como acontece no Brasil resultado do sistema político e econômico, São José dos Campos também apresenta uma grande parcela de população socialmente excluída. 
A exclusão social e a pobreza são problemas sociais presentes em toda a sociedade brasileira e têm sido objeto de estudo de diferentes autores, (Maricato, 1996; Santos, 1994; Martins, 1996), que utilizaram diferentes metodologias para tentar entender o processo de urbanização, principalmente nas grandes cidades, onde prevalece a desigualdade e a discriminação social. Por sua gravidade e efeitos perversos sobre o conjunto do espaço e da sociedade, a questão exige tratamento criterioso que dê conta de suas múltiplas manifestações e tentativas de enfrentamento.

Em São José dos Campos, essa população se encontra em bolsões periféricos e em loteamentos clandestinos na Região Leste e Norte. O processo que definiu a atual configuração da cidade, não foi adequadamente acompanhado pelo poder publico, principalmente na última década, fazendo com que as ações de planejamento tivessem um papel apenas mitigador, sempre defasado em relação ao seu crescimento econômico.

A concentração da população de menor renda, assim como na maioria das cidades brasileiras, encontra-se na periferia de São José dos Campos, mais especificamente nas zonas de expansão urbana I e II.

A exemplo, pudemos verificar no Capítulo 2 item 2.2.4, que parte considerável da Zona Rural, a partir de 1984, sofreu intenso processo de implantação de loteamentos clandestinos e que vários fatores contribuíram para este cenário em São José dos Campos:

1) o modelo econômico brasileiro (sistema de produção em massa) gera desigualdades crescentes de renda. Em 1960 os 10\% mais ricos tinham renda 34 vezes superior aos 10\% dos mais pobres e, 30 anos depois a diferença passou a ser 78 vezes superior ${ }^{92}$;

\footnotetext{
${ }^{92}$ Folha de São Paulo 8/03/95 - p.1-20.
} 
2) a descentralização industrial sentido metrópole-interior, responsável pelo acelerado processo de urbanização do município;

3) a queda do emprego formal e o aumento da economia informal e seu reflexo na forma de moradia através dos loteamentos precários e favelas;

4) a baixa densidade residencial bruta apresentada pelo município, ocasionando maior custo de vida para os munícipes e maiores encargos para a administração pública;

5) a especulação imobiliária e o aumento do preço da terra urbana;

6) a descontinuidade administrativa havida no período de 1981-1991;

7) fiscalização administrativa ineficiente.

Ao analisarmos o território de São José dos Campos destacamos três áreas da macrozona urbana eleitas como pontuais localizadas na Região Norte, Leste e Oeste respectivamente, para entender a relação dessas áreas com a legislação de uso e ocupação do solo de 1997 (fig. 4.5) e suas tendências.

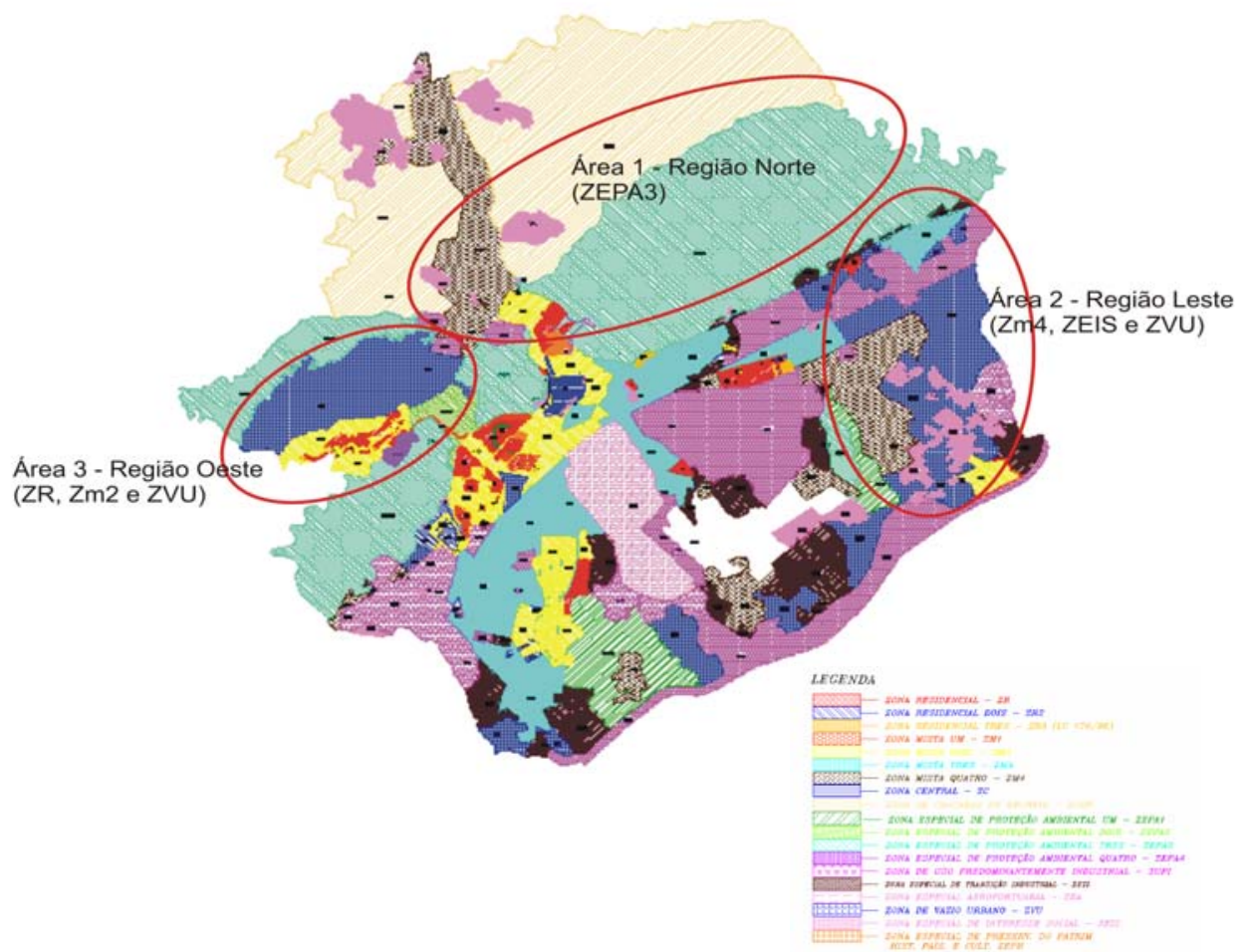

Figura 4.5 - Mapa do Zoneamento de 1997 e áreas a serem analisadas Fonte: Secretaria de Planejamento Urbano, P.M.S.J.C., 2007. 


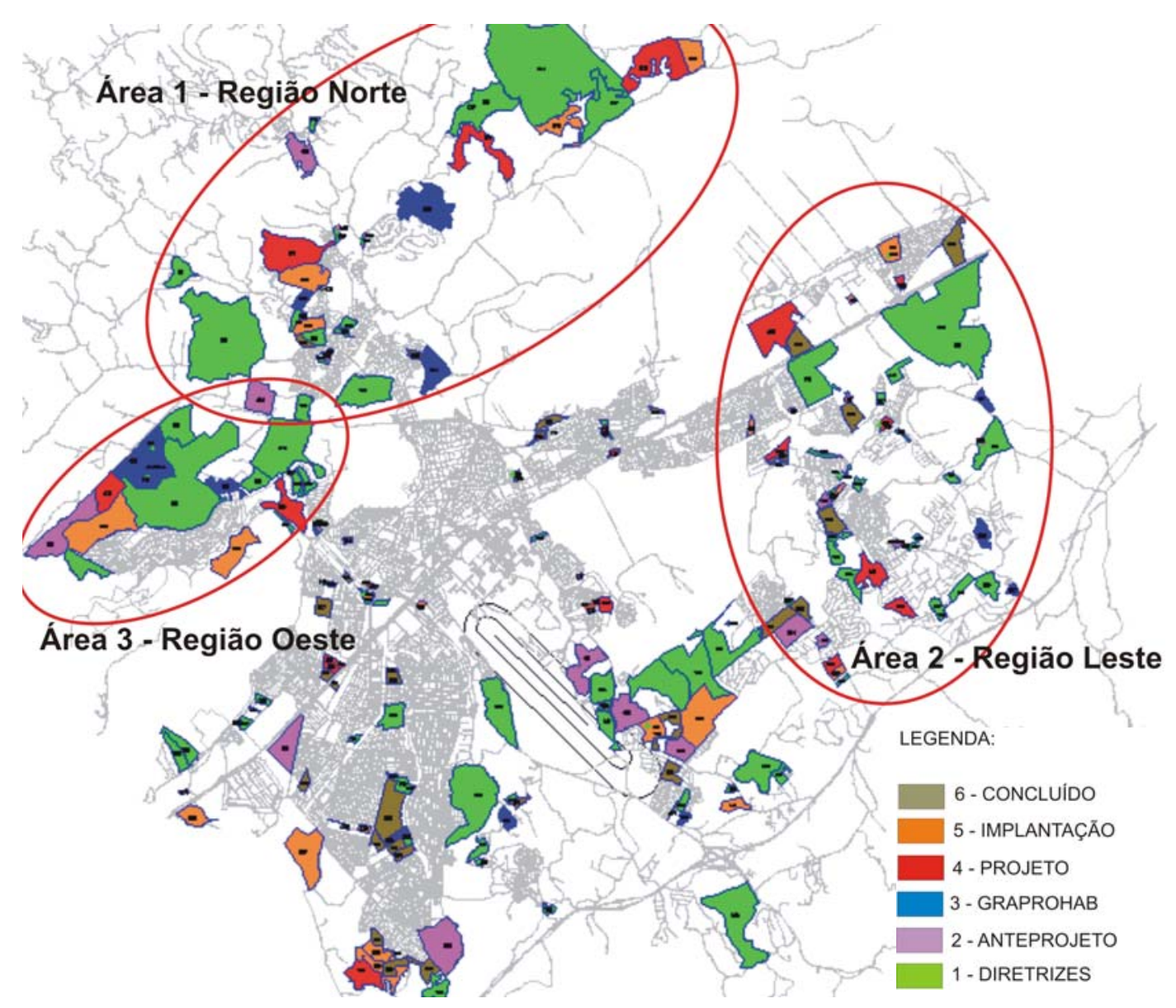

Figura 4.6 - Mapa de fases dos novos loteamentos e áreas a serem analisadas Fonte: Secretaria de Planejamento Urbano, P.M.S.J.C., 2007.

\subsubsection{Perfil socioeconômico das regiões}

Para o estabelecimento do perfil socioeconômico dessas regiões selecionamos um conjunto de variáveis, a partir da base de dados da Pesquisa de Instrumentação do Planejamento Urbano e Avaliação do Déficit Habitacional em São José dos Campos de 2003 e informações censitárias.

O conjunto selecionado para este estudo compreende as variáveis demográficas, habitacionais, de circulação e socioeconômicas. Estas foram definidas dentre aquelas que possibilitam monitorar os vetores de crescimento da cidade, o conhecimento dos aspectos socioeconômicos da população e a percepção de problemas 
por parte desta população, que estão diretamente relacionados ao uso e ocupação do solo.

Tais informações relacionadas com o Perfil da Estrutura Urbana permitem obter subsídios técnico-científicos para uma análise de tendências de ocupação dessas áreas.

Apresentamos o mapa dos setores socioeconômicos (Fig.4.7), mapa de habitantes por setores econômicos por região (4.8) e a tabela 4.5 com dados da população de São José dos Campos, segundo as regiões.

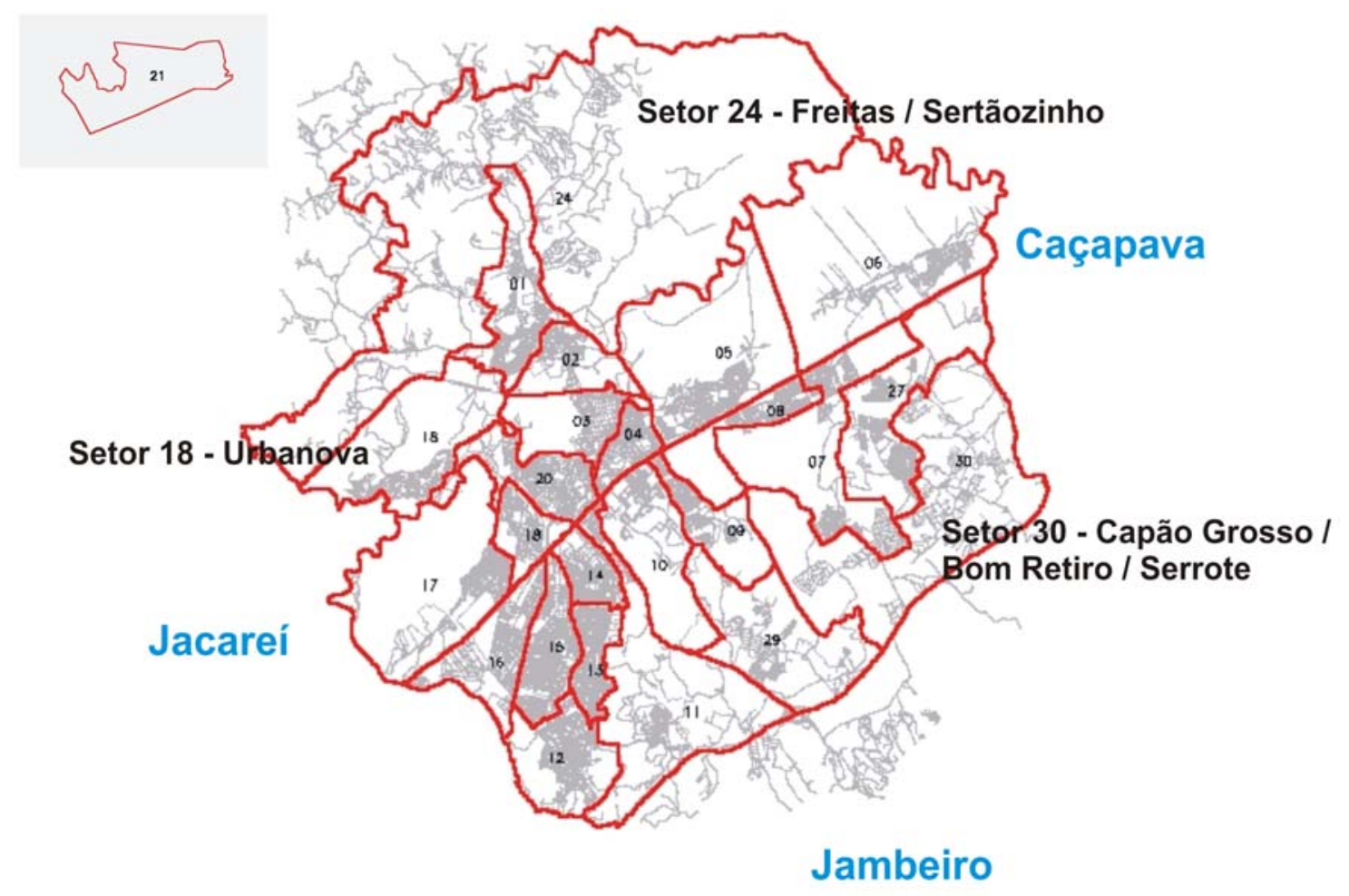

Figura 4.7 - Mapa dos Setores Socioeconômicos

Fonte: Secretaria de Planejamento Urbano, P.M.S.J.C., 2003. 


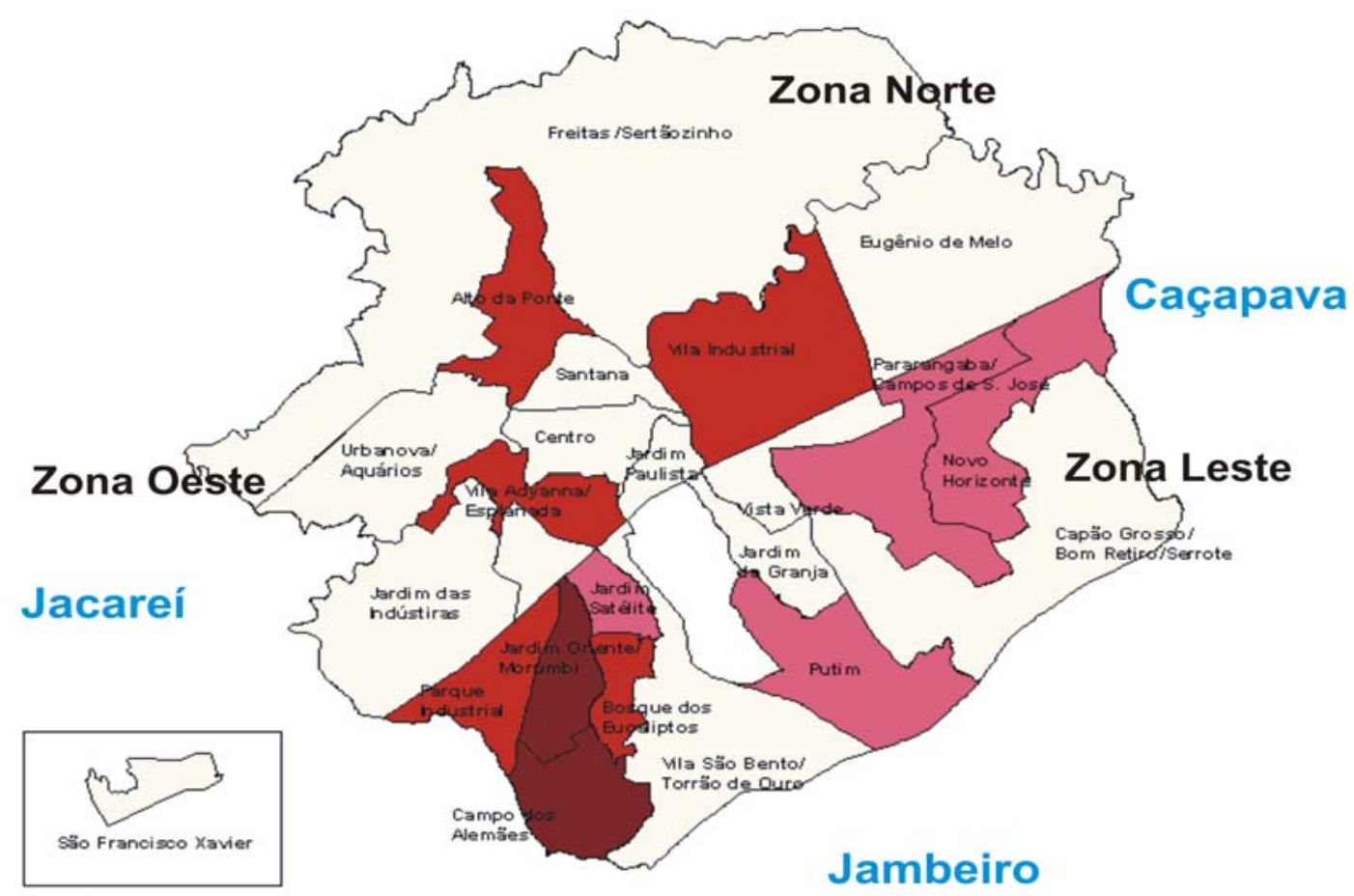

Figura 4.8 - Mapa de habitantes por setores econômicos

Fonte: Pesquisa de instrumentação do planejamento urbano e avaliação do déficit habitacional em São José dos Campos. NEPO/UNICAMP/PMSJC, 2003.

Tabela 4.5 - População segundo regiões - Município de São José dos Campos - 2000

\begin{tabular}{lccccc}
\hline Região & $\begin{array}{c}\text { População } \\
\text { total 2000 }\end{array}$ & $\begin{array}{c}\text { Distribuição } \\
\text { relativa (\%) }\end{array}$ & $\begin{array}{c}\text { Domicílios } \\
\text { ocupados }\end{array}$ & $\begin{array}{c}\text { Distribuição } \\
\text { relativa (\%) }\end{array}$ & $\begin{array}{c}\text { Número de } \\
\text { pessoas } \\
\text { por domicílio }\end{array}$ \\
\hline Centro & 70.863 & 13,31 & 21.586 & 15,07 & 3,28 \\
Norte & 61.504 & 11,55 & 16.436 & 11,48 & 3,74 \\
Leste & 136.180 & 25,58 & 35.753 & 24,95 & 3,81 \\
Sudeste & 38.761 & 7,28 & 9.598 & 6,7 & 4,04 \\
Sul & 199.913 & 37,55 & 52.698 & 37,8 & 3,79 \\
Oeste & 25.182 & 4,73 & 7.147 & 4,99 & 3,52 \\
Total & 532.403 & 100 & 143.218 & 100,99 & 3,72 \\
\hline
\end{tabular}

Fonte: Secretaria de Planejamento e Meio Ambiente, PMSJC, com base no Censo Demográfico de 2000 - IBGE.

A partir da institucionalização do PDDI-1995 e da Lei Complementar $n^{\circ}$ 165/97 que dispõe sobre o Parcelamento, Uso e Ocupação do Solo de São José dos Campos pudemos observar que, no período de 1995 a 2005, a urbanização do município ocorreu, em linhas gerais, mediante um processo de parcelamento do solo nas áreas de expansão urbana da Região Leste, voltado para uma população de menor poder 
aquisitivo e, nas regiões Oeste e Norte, mais precisamente Urbanova e nas colinas da Vargem Grande, para a população de médio e alto poder aquisitivo.

Quanto ao restante da área compreendida pela Macrozona de Expansão Urbana II, decorridos dez anos da vigência do PDDI-95, observamos que, apesar desse plano haver recomendado em suas diretrizes pelas características topográficas, dificuldades de acessibilidade, uso predominantemente rural e restrições ambientais, não houve iniciativa para a implantação de loteamentos de chácaras de recreio por parte do setor imobiliário.

O processo de urbanização de São José dos Campos, conforme detalhado no Capítulo 2, caracterizou-se ao longo do tempo, por ações voltadas para transpor os obstáculos físicos existentes, a exemplo das Rodovias Presidente Dutra, SP-50, Rodovia dos Tamoios (SP-99) e SP-66, Estrada de Ferro Central do Brasil e o Rio Paraíba do Sul, que tiveram papel determinante na formação do tecido urbano atual do município, sendo fundamentais para garantir a circulação da população e permitir a comunicação entre regiões.

Além dessas interferências, outros obstáculos dificultam a integração e impõem restrições à mobilidade da população do município, como as áreas ocupadas pelo Centro Técnico Aeroespacial - CTA e pela Refinaria Henrique Lage - REVAP, e a própria geografia da cidade, composta de platôs, extensas planícies aluvionares e fundos de vale. (fig. 4.9) 


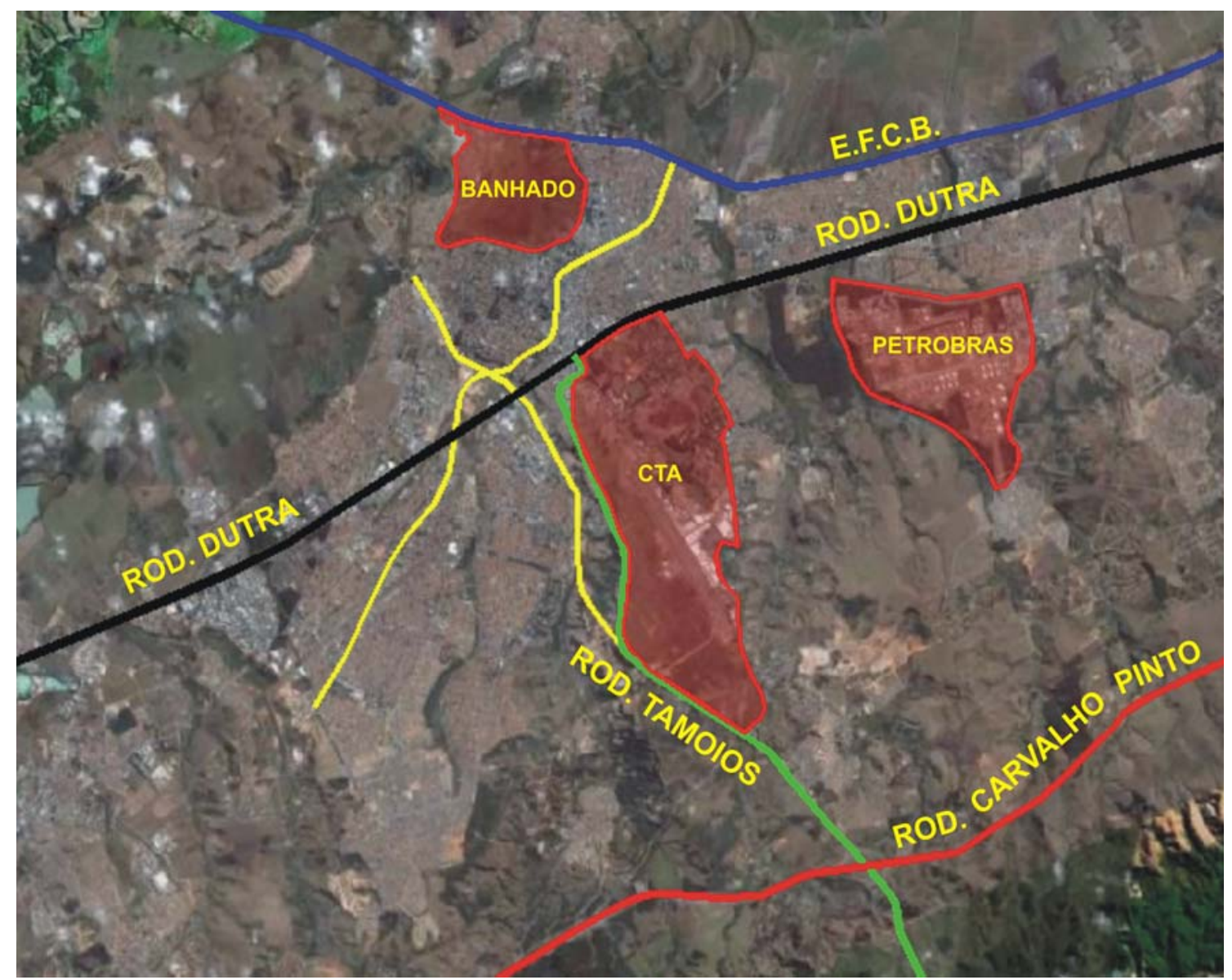

Figura 4.9 - Foto aérea com os principais obstáculos (CTA, Petrobrás e Banhado) e principais eixos viários

Fonte: Secretaria de Planejamento Urbano, P.M.S.J.C., 2007.

As ligações rodoviárias existentes ao longo da malha urbana da cidade trazem vantagens para o município posicionando-o no eixo de ligação de dois pólos econômicos importantes (São Paulo e Rio de Janeiro), possibilitando a articulação do município às demais regiões do país. Por outro lado, a crescente urbanização ao longo destes eixos rodoviários fez com que a cidade incorporasse a rodovia ao sistema viário local, com a conseqüente assimilação dos problemas decorrentes do tráfego nestes dois sistemas distintos: o urbano e o rodoviário. A construção, ao longo, do tempo das vias marginais à Rodovia Presidente Dutra, destinada ao tráfego local, tem sido uma das alternativas para resolver esta questão.

Como alternativa viária, vem se concretizando a implantação do Anel Viário de São José dos Campos, que faz parte da Macroestrutura Viária do Município, e tem 
como objetivo facilitar a integração e a circulação entre a Região Centro e as Regiões Sul e Leste e, futuramente, com a Região Norte, oferecendo uma condição viária mais rápida e direta entre estas regiões, entretanto, o projeto do Anel Viário não alcança todo o tecido urbano, o que faz com que determinadas regiões ainda dependa do sistema rodoviário.

A Lei Complementar n 165/97, de Parcelamento, Uso e Ocupação do Solo, não definiu, dentro do conceito do zoneamento, a figura dos corredores viários. Desta forma, associou ao sistema viário estrutural os parâmetros de ocupação, como áreas e testadas de lotes, muitas vezes inadequados às funções das vias.

A Lei Complementar $n^{\circ}$ 261/03 procurou corrigir essas distorções para as vias integrantes do Anel Viário, solução que não atendeu integralmente a necessidade da malha urbana.

A seguir, apresentaremos os aspectos demográficos, habitacionais, de circulação e socioeconômicos das Regiões Norte, Leste e Oeste de São José dos Campos.

\section{- Região Norte}

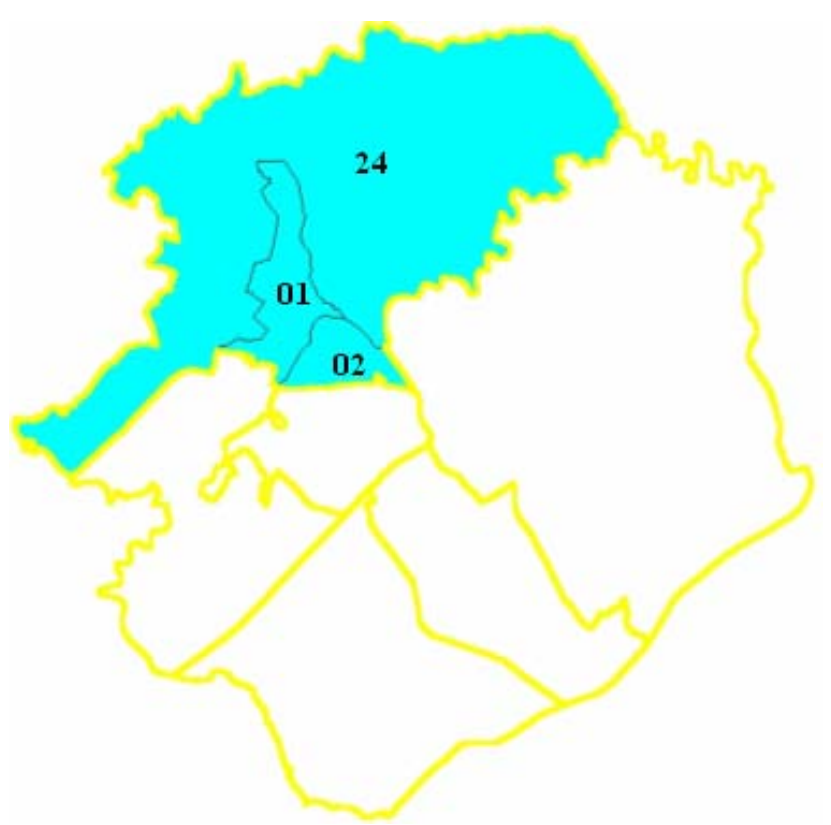

Figura 4.10 - Mapa Região Norte

Fonte: Secretaria de Planejamento Urbano, P.M.S.J.C., 2006 
A Região Norte é formada por três setores socioeconômicos, sendo que um deles, o Setor 1 - Alto da Ponte é bastante populoso, abrigando cerca de 5,6\% da população da cidade. No Setor 2 há uma área de APA (a várzea do Rio Paraíba, em Santana) e para fins da Pesquisa de Instrumentação, houve um agrupamento dos setores 23, 24 e 25 da setorização original (Freitas, Caetê e Sertãozinho), formando um único setor de ocupação predominantemente clandestina, chamado Setor 24 - Freitas/ Sertãozinho. Outra peculiaridade deste setor é a existência de duas APAS a do Jaguari (24 A) e da Vargem Grande (25 A), objeto desta análise.

Atualmente, a Região Norte abrange, aproximadamente, 10\% da população urbana do município que, no período $1991-2000$ cresceu a uma taxa de cerca de 1,5\% ao ano. Apresentaremos, a seguir, o perfil da área a ser analisada nesse estudo, o setor 24 Freitas / Sertãozinho. (Tabela 4.6)

Tabela 4.6 - Região Norte 24 Setor Freitas/Sertãozinho

\section{Região Norte}

Setor de pequena população, porém com alta taxa de crescimento na última década, notadamente nos bairros de ocupação clandestina. O perfil etário é caracterizado por elevado percentual de crianças. O desemprego apresenta-se dentro da média elevada da cidade e a escolaridade bem abaixo da média. A população encontra-se empregada principalmente no setor de serviços, sendo que, em relação ao padrão da cidade, existe um percentual elevado de ocupados na agropecuária e poucos na

Setor 24 Freitasl Sertãozinho: indústria. Predominam as classes de consumo $D$ e $C$, sendo presente também a B e a $\mathrm{E}$. Há deficiência na acessibilidade ao transporte coletivo, sendo que em cerca de $57 \%$ dos domicílios não existe automóvel. A distribuição dos domicílios quanto ao tipo indica que o setor é de configuração horizontal e há presença de cômodos acima da média da cidade. Os domicílios "próprios já pagos" aparecem em percentual elevado. É importante destacar, nesse setor, a ocorrência de domicílios cedidos.Com relação aos domicílios ocupados através de aluguel, concentram-se nas faixas de renda inferiores a cinco salários mínimos. A falta de áreas verdes é considerada um problema grave em mais de $30 \%$ dos domicílios.

Fonte: Secretaria de Planejamento Urbano, PMSJC, 2006. 
A maior parte da Região Norte é compreendida pela atual Zona de Chácaras de Recreio, caracteriza-se pela topografia acidentada de morros, ocorrência de loteamentos clandestinos e grandes vazios predominantemente rurais.

Com a Resolução CONAMA n 303 de 2002, que dispõe sobre parâmetros, definições e limites de Áreas de Preservação Permanente estabelecidas pelo Código Florestal, as áreas de topo de morro foram consideradas espaços especialmente protegidos, como instrumentos de relevante interesse ambiental, condição esta que impede o uso e ocupação de grande parte dos terrenos da Zona de Chácaras de Recreio.

Desde o advento da legislação para chácaras de recreio, foram aprovados, até o momento, dois loteamentos voltados para a população de médio e alto poder aquisitivo e, atualmente, encontram-se em aprovação três loteamentos deste porte, todos junto à Estrada da Vargem Grande.

Com bairros tipicamente residenciais, a acessibilidade viária dessa região está estruturada unicamente num binário radial em relação à área Central com a travessia da linha férrea existente em viadutos. No sentido centro-bairro a Av. Olivo Gomes com cinco faixas e sua continuação, a Av. Princesa Isabel com três faixas, oferecem um bom desempenho viário. No sentido bairro-centro a Av. Rui Barbosa, uma via estreita, já apresentando certa saturação nos horários de pico. Para a transposição do Rio Paraíba do Sul, existem duas pontes, Ponte Minas Gerais e Ponte da Rhodia, onde o binário também apresenta sinais de saturação.

Além desse eixo viário, a região de expansão urbana norte, situada na margem esquerda do Rio Paraíba do Sul, está apoiada nas estradas municipais, que ainda mantêm as dimensões das antigas estradas rurais. A SP-50 funciona como elemento integrador dos bairros da região, uma vez que a topografia acidentada dificulta a ligação entre os diversos loteamentos. 


\section{- Região Leste}

Figura 4.11 - Mapa da Região Leste

Fonte: Secretaria de Planejamento Urbano, P.M.S.J.C., 2006.

A Região Leste é formada por seis setores socioeconômicos, abrangendo cerca de $1 / 4$ da população urbana de São José dos Campos.

Dentro dessa região que, no período 1991/2000 cresceu a uma taxa de cerca de $3,5 \%$ ao ano, observamos que o Setor 5 - Vila Industrial tem maior população e apresentou uma taxa negativa de crescimento; o Setor 8 quase não apresentou crescimento e o Setor 6 cresceu no período um pouco abaixo da média da cidade. Por outro lado, os setores 7, 30 e 31 apresentaram crescimento intenso (notadamente o 31).

Para fins de realização da Pesquisa de Instrumentação, houve um agrupamento dos setores 30 (Capão Grosso) e 31 (Serrote) da setorização original, formando um setor de ocupação basicamente clandestina, denominado Setor 30 - Capão Grosso/ Bom Retiro/ Serrote. Outra peculiaridade deste setor é a existência de duas APAS nos setores 5 e 6 (Várzea do Paraíba na Região Leste). 
Com relação ao perfil etário, observamos a prevalência de um perfil bem mais jovem nos setores onde a ocupação ocorreu de forma predominantemente clandestina. No Setor 30 , mais de $50 \%$ da população é formada por crianças e jovens, chegando à cerca 1/3 a parcela só de crianças nesse setor. (Tabela 4.7)

Tabela 4.7 - Região Leste 30 Setor Capão Grosso/ Bom Retiro/ Serrote

\section{Região Leste}

Setor de tamanho médio em termos populacionais que apresentou forte crescimento nas duas últimas décadas. Quanto ao perfil etário, destaca-se o elevado percentual de crianças. A taxa de desemprego situa-se bem acima da

Setor 30

Capão Grossol Bom Retiro/ Serrote média da cidade, e a escolaridade é bem inferior. A população ocupada está inserida principalmente no ramo da prestação de serviços $(65,2 \%)$. Há predominância da classe de consumo $D$, seguida pela $C$, com presença de $E$ acima da média. Não existe automóvel em $60 \%$ dos domicílios e a acessibilidade ao transporte coletivo é inferior ao padrão geral. Observando as variáveis habitacionais, podemos perceber a configuração horizontal do setor e a presença de cômodos. A forma de ocupação predominante é de domicílios próprios, mas há um percentual de "cedidos" que é superior à média da cidade. Com relação aos domicílios ocupados através de aluguel, estão concentrados nas faixas de renda inferiores a cinco salários mínimos

Fonte: Secretaria de Planejamento Urbano, PMSJ, 2006.

O setor 30 compreendido pela Estrada Municipal do Mato Dentro / Divisa Intermunicipal com Caçapava é área de franca expansão urbana. Esse setor apresenta um predomínio residencial unifamiliar popular, com um comércio linear de âmbito local que não constitui um sub-centro comercial. Constata-se a existência de extensos vazios urbanos, permeados por loteamentos clandestinos. Estudos têm sido feitos para a implantação de grande loteamento que visa o parcelamento para fins residencial, 
comercial, de serviços e industrial, atualmente em fase de consulta ambiental prévia junto a Secretaria de Estado de Meio Ambiente na divisa intermunicipal com Caçapava.

Ainda no que se refere ao processo de ocupação urbana dessa região, ressaltamos o Jardim São José II, local que absorveu as comunidades transferidas das favelas Caparaó, Nova Detroit e Nova Tatetuba dentro do Programa Habitacional HabitarBrasil. Outro destaque é a existência das engarrafadoras de gás GLP, que transformaram suas adjacências em um local considerado de risco pela CETESB, bem como a existência do aterro para resíduos sólidos industriais que, por força das normas ambientais, demandou a exigência de uma faixa sanitária de 500m ao seu redor.

O setor compreendido pela Estrada Municipal do Mato Dentro - Cajurú, em franca expansão urbana de caráter popular, encontra-se estruturado exclusivamente sobre a Estrada Municipal do Cajurú. Caracteriza-se ainda pela existência de vazios permeados por loteamentos clandestinos. Face à contigüidade com a propriedade da Refinaria Henrique Lage - REVAP, estabeleceu-se ao longo da Estrada Municipal do Cajurú, o zoneamento industrial e de áreas de proteção ambiental, visando garantir não só a proteção de recursos naturais existentes, no caso das APA's, mas também uma transição entre as atividades industriais de maior porte e incomodidade e usos residenciais. Ressalta-se ainda a existência de grandes áreas estabelecidas como ZUPI e ZETI, no intuito de coibir a ocupação residencial junto à Rodovia Carvalho Pinto.

A Região Leste encontra-se estruturada sobre as estradas municipais, antigas estradas rurais, em especial a Avenida Tancredo Neves, porta de acesso da Região Leste, sendo esta via responsável pela integração da região para o restante da cidade.

As restrições impostas pela topografia e pela ruptura do tecido urbano decorrente da ocupação de grandes glebas industriais, de barreiras físicas criadas pela ferrovia e rodovia e pelas faixas de alta tensão, provocaram a descontinuidade de traçado das vias, sobrecarregando o trânsito do eixo viário formado pelas Avenidas Juscelino Kubitschek, Pedro Friggi e Tancredo Neves. 
Este eixo viário atende às demandas de viagens geradas das nucleações urbanas mais consolidadas da região e recebe, principalmente, nas Avenidas Pedro Friggi e Tancredo.Neves, o trânsito de caminhões, inclusive de cargas perigosas.

Além desse eixo viário, a região de expansão urbana leste, incluindo os parcelamentos clandestinos, está apoiada nas estradas municipais que ainda mantêm as dimensões das antigas estradas rurais.

A Rodovia Presidente Dutra, em decorrência da carência viária, e pela descontinuidade das marginais ao longo do município, atende aos deslocamentos desses bairros.

\section{- Região Oeste}

18

\section{9}

17

Figura 4.12 - Mapa Região Oeste

Fonte: Secretaria de Planejamento Urbano, P.M.S.J.C., 2006.

A Região Oeste de São José dos Campos é a região que tem o menor número de habitantes do município, porém de maior crescimento relativo no último período intercensitário (6,5\% ao ano), a Região Oeste é formada por dois setores socioeconômicos e abriga cerca de $6,6 \%$ da população urbana de SJC. Todos os setores 
da Região Oeste apresentaram taxas de crescimento superiores à média da cidade ao longo da última década. Outra característica da setorização dessa região é a existência de uma APA no Setor 17 - Jardim das Indústrias, a APA Oeste do rio Paraíba.

Para fins da Pesquisa de Instrumentação, houve um agrupamento dos setores 18 (Urbanova) e 19 (Aquárius) da setorização original, formando o Setor 18 (Urbanova/ Aquárius). (Tabela 4.8)

Com relação à distribuição etária, trata-se de uma região com predominância de população adulta (faixa dos 25 aos 59 anos), com percentuais de crianças e idosos inferiores à média da cidade.

Tabela 4.8 - Região Oeste Setor 18 Urbanova/Aquárius

\section{Região Oeste}

Setor pequeno em termos populacionais, que apresentou crescimento acima da média da cidade. Quanto ao perfil etário, destaca-se por um maior percentual de população adulta. Apresenta a menor taxa de desemprego da cidade e o nível de

Setor 18 UrbanovalAquárius escolaridade é bem acima da média. O setor de prestação de serviços absorve quase a metade dos ocupados, mas a parcela de empregados no setor público é superior ao padrão geral. Predomina a classe de consumo A. A média de automóveis por domicílio é alta e a acessibilidade ao transporte público é bem inferior ao padrão da cidade. A observação das variáveis relacionadas com a habitação aponta uma configuração bem mais vertical desse setor do que a média geral e um menor percentual de domicílios alugados. Cabe observar que este setor é composto por dois espaços de configurações diferentes, sendo um deles predominantemente vertical (o Aquárius), e o outro horizontal (a Urbanova). Dentre os domicílios alugados, há concentração daqueles que se classificam nas faixas de renda acima de cinco salários mínimos, formando um estoque de aproximadamente 260 habitações.

Fonte: Secretaria de Planejamento Urbano, PMSJC, 2006. 
O setor compreendido pela Urbanova caracteriza-se pela consolidação das áreas residenciais de caráter unifamiliar e pela concentração de loteamentos fechados, bem como pela ausência de atividades comerciais e de serviços. O bairro apresenta uma grande valorização dos imóveis, o que vem contribuindo para um forte processo de especulação imobiliária dos extensos vazios existentes. A intensa ocupação urbana associada à grande expansão do campus da Universidade do Vale do Paraíba - UNIVAP, vem comprometendo a acessibilidade que hoje é feita exclusivamente por uma via de acesso.

Essa região apresenta um sistema viário apoiado em vias radiais. O setor da Urbanova é acessado somente pelo eixo viário formado pela Avenida Lineu de Moura e pela ponte sobre o Rio Paraíba do Sul, apresentando sinais de saturação em horário de pico.

Em decorrência da segmentação causada pela presença da várzea do Rio Paraíba do Sul, não há integração viária do bairro Urbanova com os bairros Jardim das Indústrias e Limoeiro.

\subsubsection{Análise das áreas e suas tendências}

A seguir, mais especificamente, analisaremos três áreas pontuais nas Regiões Norte, Leste e Oeste de São José dos Campos com o objetivo de compreender a relação dessas áreas com a legislação urbanística.

\section{- Área 1 - Região Norte}

A área 1, Várzea do Paraíba, localiza-se às margens da Estrada da Vargem Grande que liga a Região Norte de São José dos Campos ao município de Caçapava.

Essa região, atualmente, tem atraído a atenção do mercado imobiliário - com o objetivo de atender a uma população de renda melhor, pois ali estão sendo implantados loteamentos fechados. 


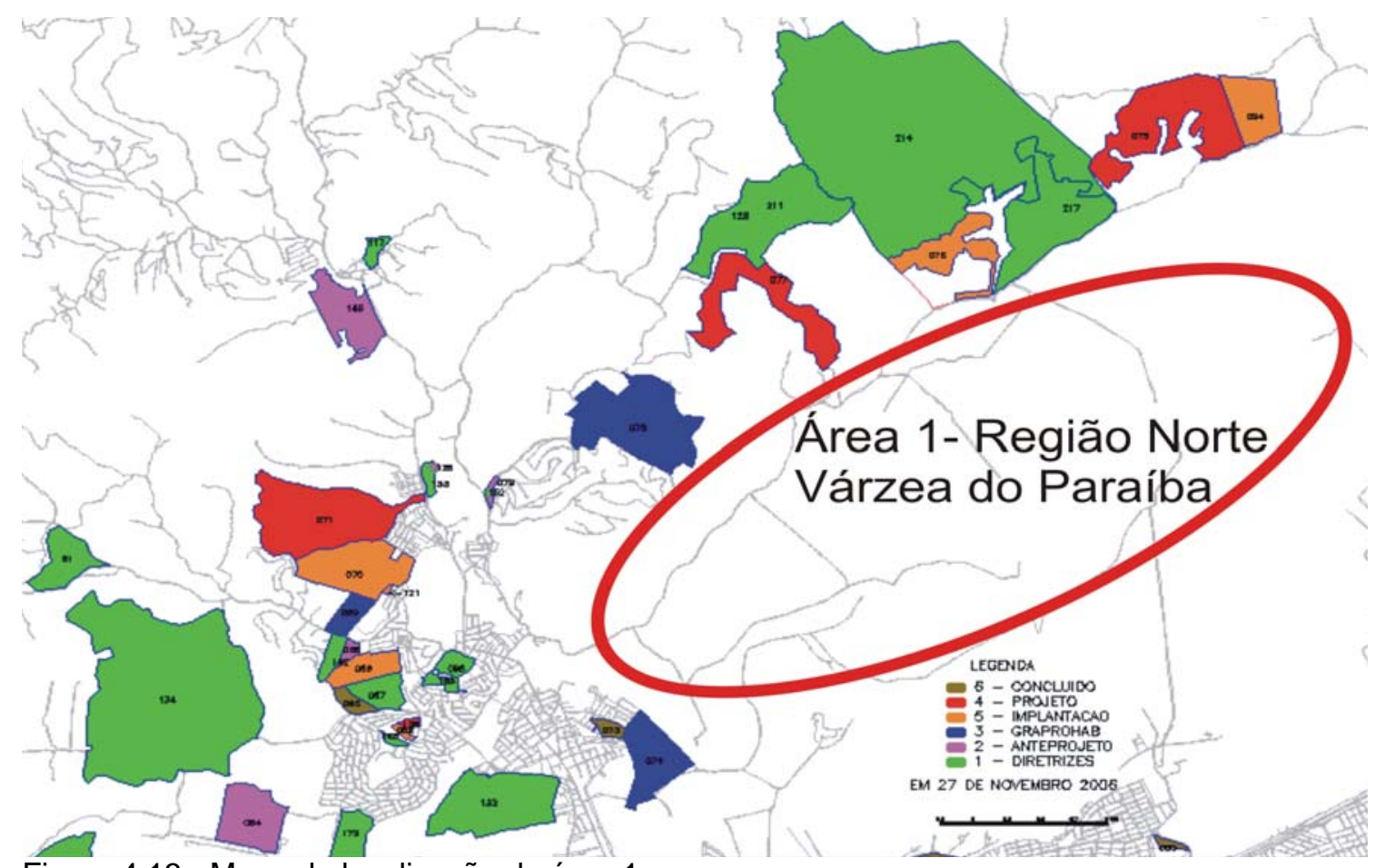

Figura 4.13 - Mapa de localização da área 1

Fonte: Secretaria de Planejamento, P.M.S.J.C., 2007.

Ao analisarmos o mapa da figura 4.13, com a delimitação da área 1, podemos observar que na margem esquerda da Estrada Municipal da Vargem Grande existem um grande número de loteamentos com características de condomínios fechados já implantados ou em fase de diretrizes e análises na Prefeitura.

O que verificamos, mais especificamente, é que entre o Rio Paraíba do Sul e a Estrada da Vargem Grande existe uma grande gleba de terra com características morfológicas de várzea.

Na Lei Municipal $n^{0} 3721 / 90$, detalhada no item 3.2.7, a área 1 - Várzea do Paraíba, foi classificada como Zona Rural pelas suas características agrícolas. (fig. 4.14) 


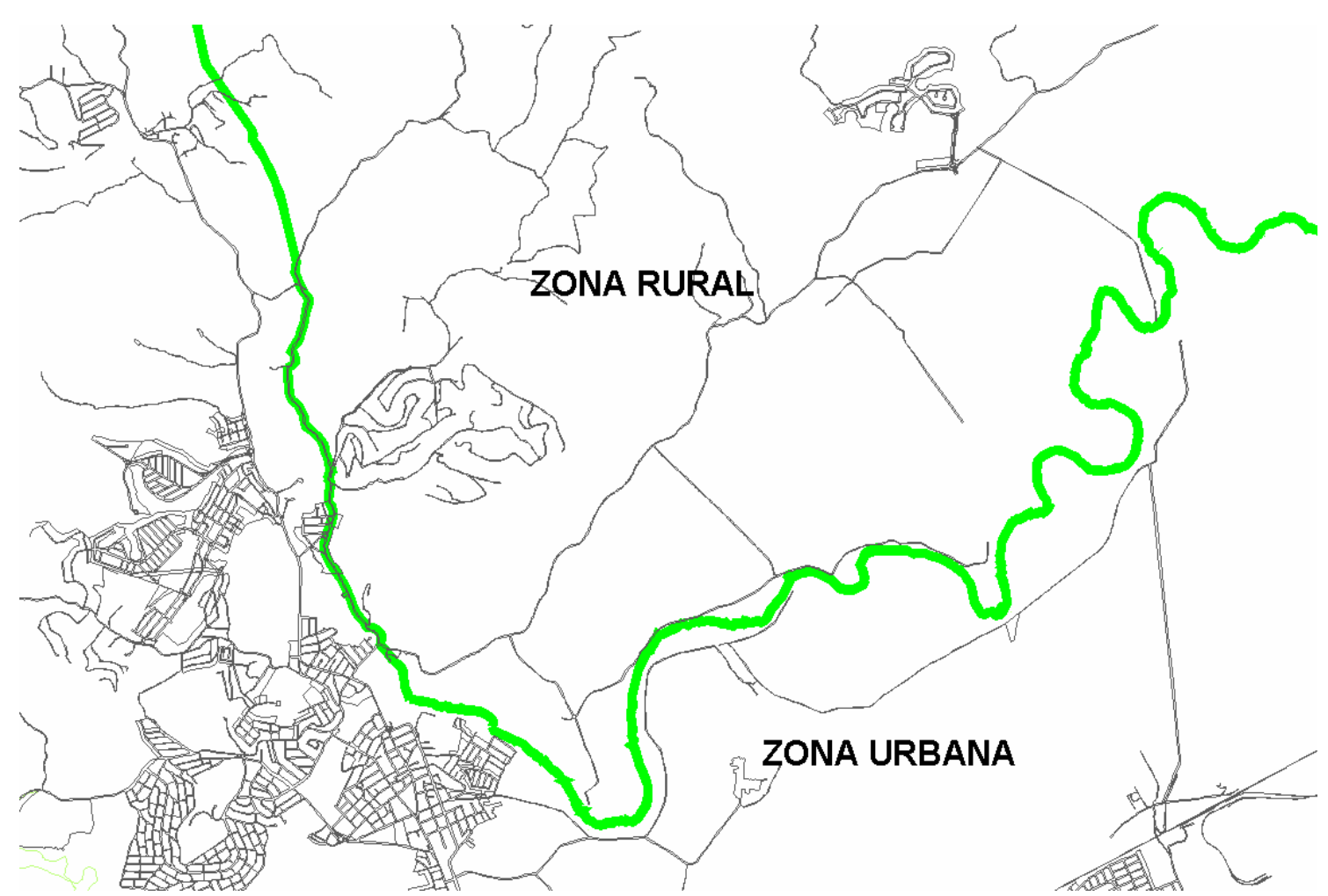

Figura 4.14 - Mapa da região da Área 1 - Lei de zoneamento de 1990 Fonte: Secretaria de Planejamento, P.M.S.J.C., 2007.

Com base no estudo elaborado pelo INPE que resultou no macrozoneamento do uso e ocupação do solo do Vale do Paraíba, o PDDI de 1995 recomendou, em suas diretrizes, que essa área deveria ser preservada ambientalmente, uma vez que se tratava de uma várzea para fins agrícolas.

A lei de zoneamento de 1997 teve o objetivo de preservar essa área, classificou-a no seu art $84^{93}$, como uma Zona Especial de Proteção Ambiental - 3.

Atualmente, a Secretaria de Planejamento de São José dos Campos desenvolveu a atualização do Plano Diretor, aprovado em 17 de novembro de 2006, pela

\footnotetext{
${ }^{93}$ Segundo o Artigo 84 da Lei Complementar Municipal $n^{0}$ 165/97 - Na zona de uso ZEPA3, deverão ser atendidas as seguintes exigências: I - os empreendimentos de lazer deverão ser elaborados de forma a assegurar a valorização dos recursos naturais e paisagísticos do local, devendo sua ocupação obedecer a seguinte distribuição: a) 90\% (noventa por cento), no mínimo, da área, destinar-se-ão ao lazer, compreendendo, áreas arborizadas, ajardinadas, formação de bosque com espécimes nativas da região, quadras esportivas, playground, ou outro a critério do projeto, sendo que $50 \%$ (cinqüenta por cento) destes espaços serão destinados, obrigatoriamente, a áreas arborizadas e ajardinadas; b) as áreas referidas na alínea "a" deste artigo não poderão ser impermeabilizadas; c) coeficiente máximo de impermeabilização de $10 \%$ (dez por cento), incluindo calçamento de pedestre e a recreação coberta; II - as áreas destinadas a estacionamento não poderão ser impermeabilizadas; III - em havendo movimentação de terra deverão ser atendidas as disposições do artigo 10 , da referida lei complementar municipal.
} 
Lei Complementar Municipal $\mathrm{n}^{0} 306$ para esse município, segundo diretrizes estabelecidas na Lei Federal n 10.257/01 - Estatuto da Cidade.

Nesse novo Plano Diretor ${ }^{94}$ para São José dos Campos podemos verificar a existência de diretrizes para essa região que, em conjunto com um Plano de Estruturação Viária (PEU), ainda não aprovado e que tem o objetivo de regulamentá-lo, poderão vir a modificar as características dessa região. Destacamos das diretrizes desse plano a proposta de interligar essa área ao Anel Viário e ao Parque da Cidade. (fig. 4.15)

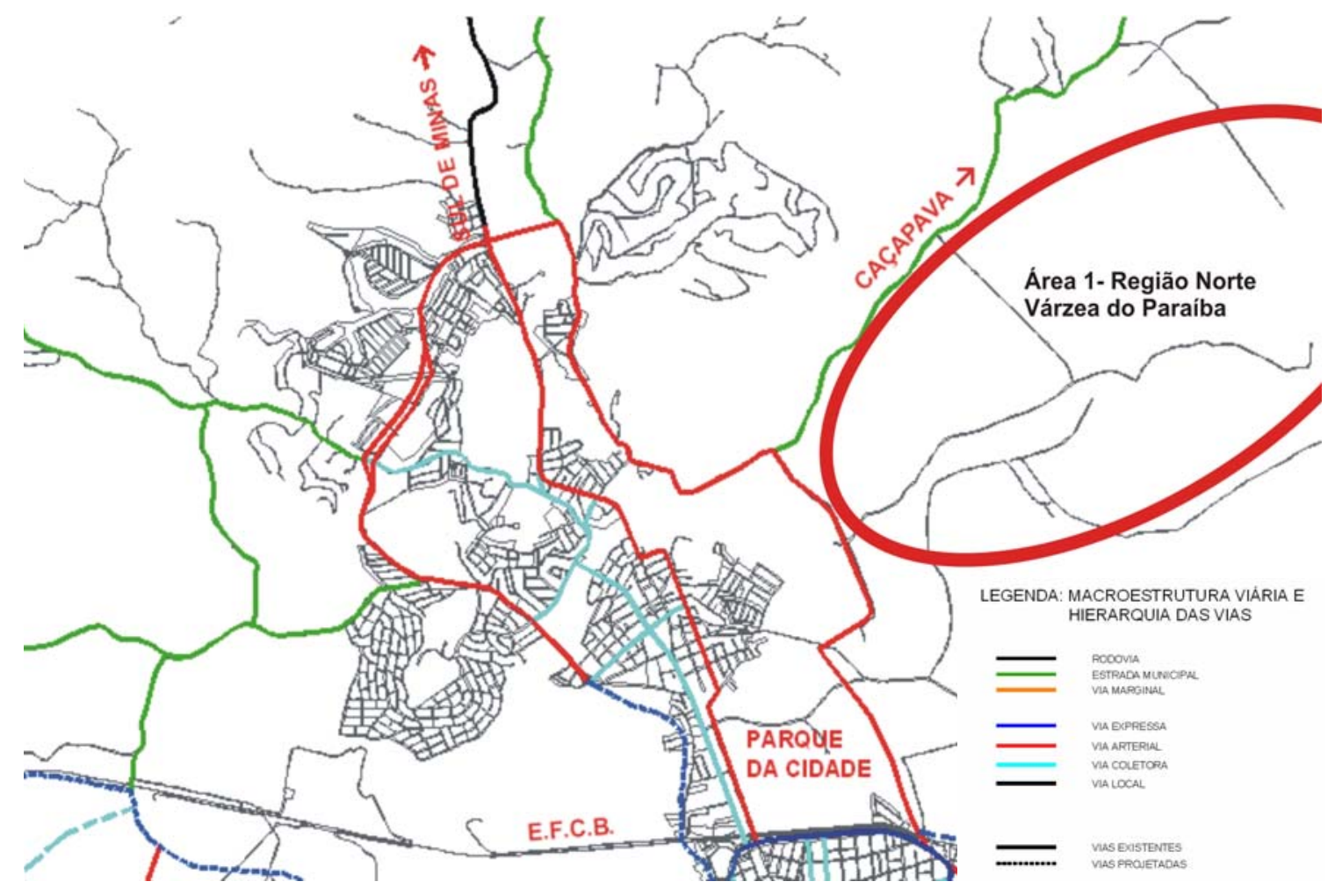

Figura 4.15 - Mapa com a proposta viária para a Região Norte - PDDI 2006 Fonte: Secretaria de Planejamento Urbano, P.M.S.J.C., 2007.

Mais recentemente, como a imprensa local já noticiou, um outro plano está sendo elaborado para o Parque da Cidade Roberto Burle Marx, área lindeira à área que aqui analisamos. O plano propõe várias ligações viárias que envolvem e irão reforçar as transformações dessa área de preservação ambiental.

${ }^{94}$ Lei Complementar Municipal $n^{0} 306$ de 17 de novembro de 2006. 
Esse plano para o Parque da Cidade propõe: a) implantação de um Centro Cultural e Teatro Municipal; b) Zoológico; c) aumento da área original do parque e d) vias de circulação que irão cruzar a várzea do banhado e circundarão e atravessarão essa área de várzea. (fig. 4.16)

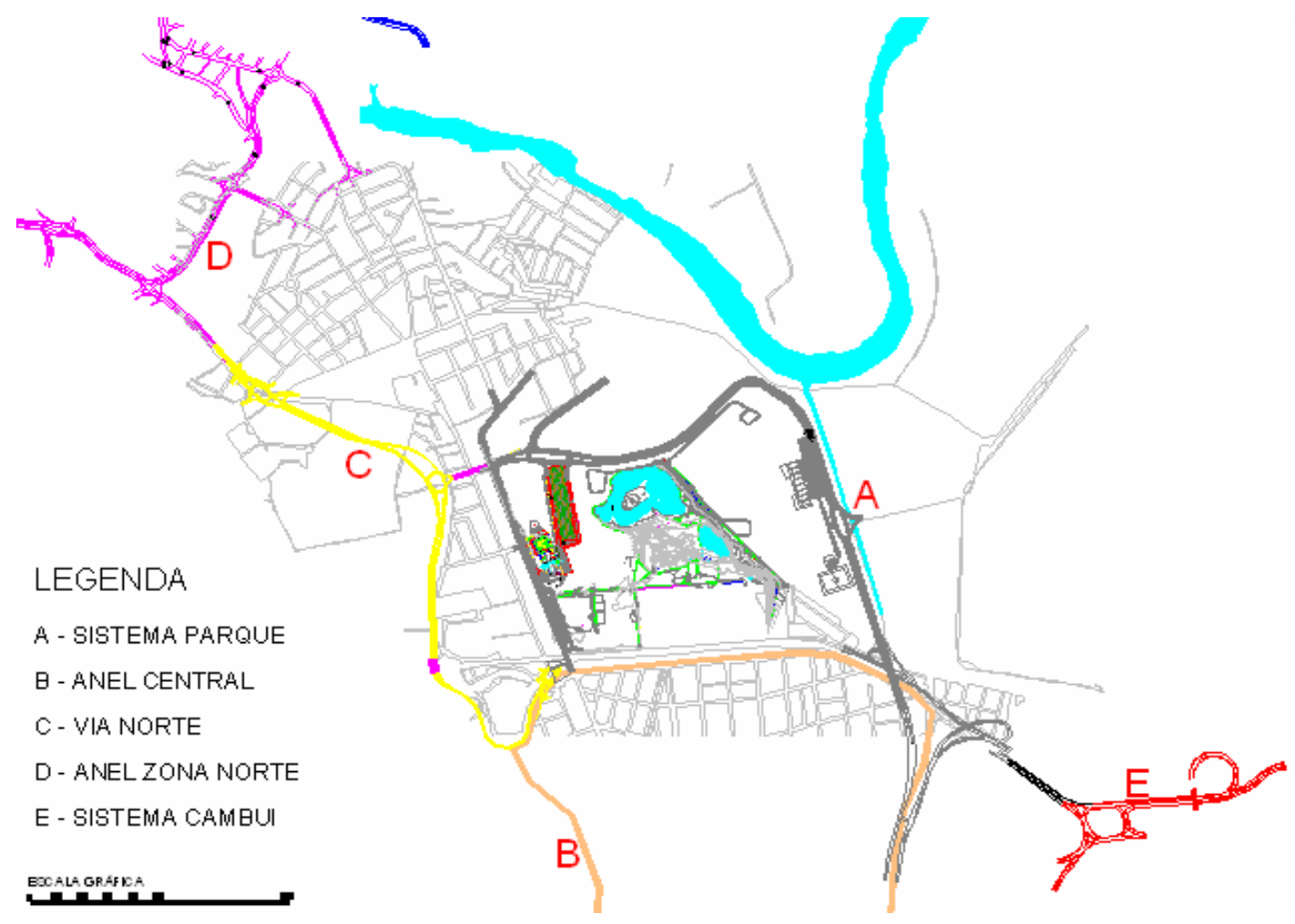

Figura 4.16 - Mapa da proposta viária do Plano Diretor para o Parque da Cidade Fonte: Secretaria de Planejamento Urbano, P.M.S.J.C., 2007. 


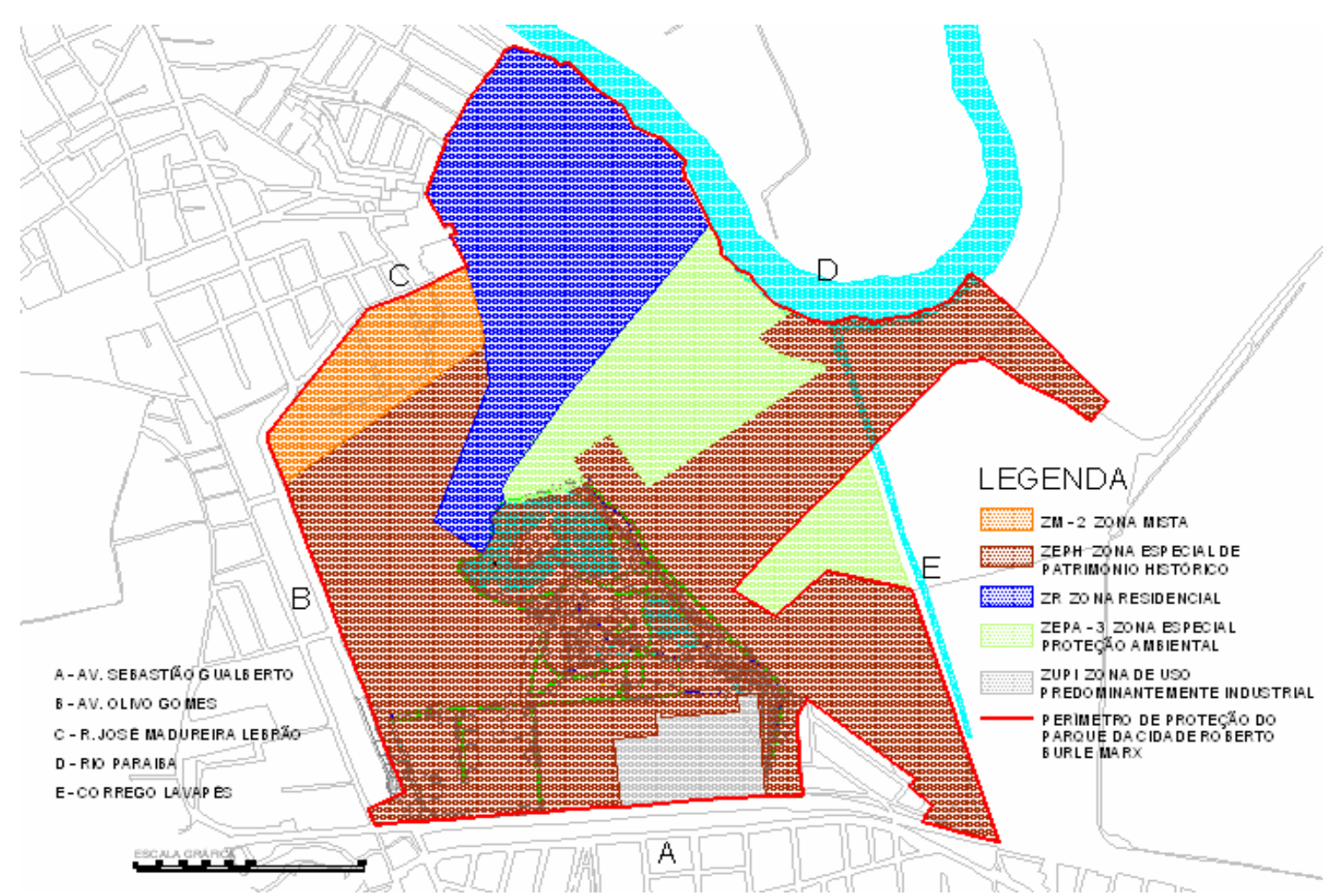

Figura 4.17 - Mapa do zoneamento proposto no Plano Diretor do Parque da Cidade Fonte: Secretaria de Planejamento Urbano, P.M.S.J.C., 2007.

Cabe ressaltar que existe uma APA Estadual que visa a preservação do banhado, mas essa não atinge essa área de várzea. Estas diretrizes que, aparentemente, estão sendo amadurecidas a tempos vêm sendo objeto de atenção.

É de se temer - diante das diretrizes propostas nesses planos e considerando que hoje, essa área encontra-se em mãos de dois ou três empresários do setor construtivo e imobiliário de São José dos Campos venha a ser ocupada por loteamentos fechados para uma população de alta renda com prejuízo ao meio ambiente.

Grande parte das questões referentes à problemática ambiental que ocorre nas cidades brasileiras é decorrente da produção e apropriação social do espaço e provoca danos ambientais.

A propósito, é importante salientar que formas predatórias de ocupação não advêm somente da população de baixa renda; há também a ocupação propiciada por grandes empreendimentos do mercado e, pelo que conhecemos até o presente, a legislação ainda não conseguiu atingir e deter esse processo. 


\section{- Área 2 - Região Leste}

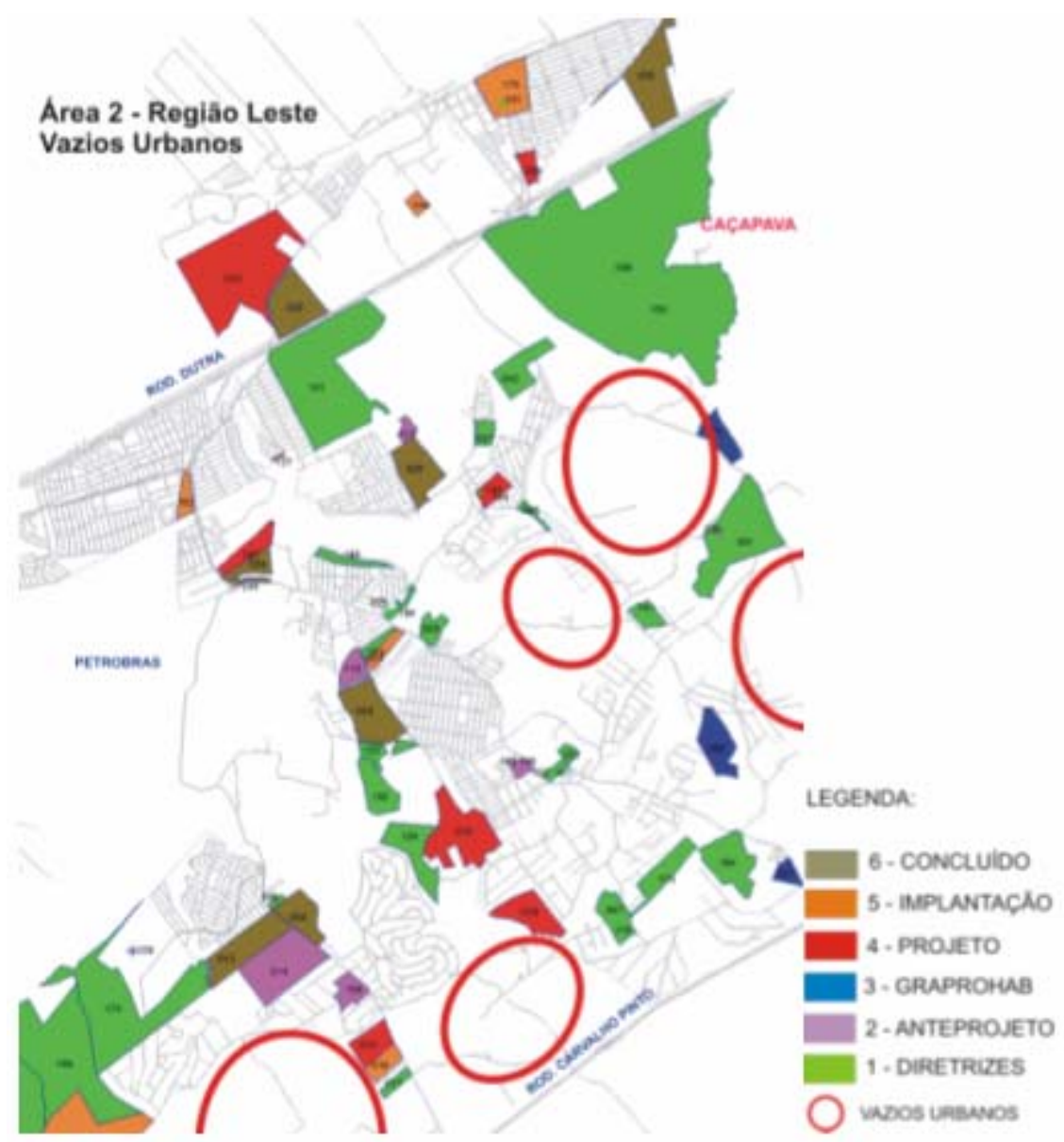

Figura 4.18 - Mapa da área 2 - Região Leste

Fonte: Secretaria de Planejamento Urbano, P.M.S.J.C., 2007.

Ao analisarmos o mapa com as fases dos novos loteamentos a serem implantados nessa região podemos observar a existência de grandes vazios urbanos entre os loteamentos regulares e clandestinos. (fig. 4.18)

Na Lei Complementar Municipal 3721/90 essa região podemos verificar que essa área era uma zona de uso denominada de Zona de Vazio Urbano. (Fig. 4.19) 


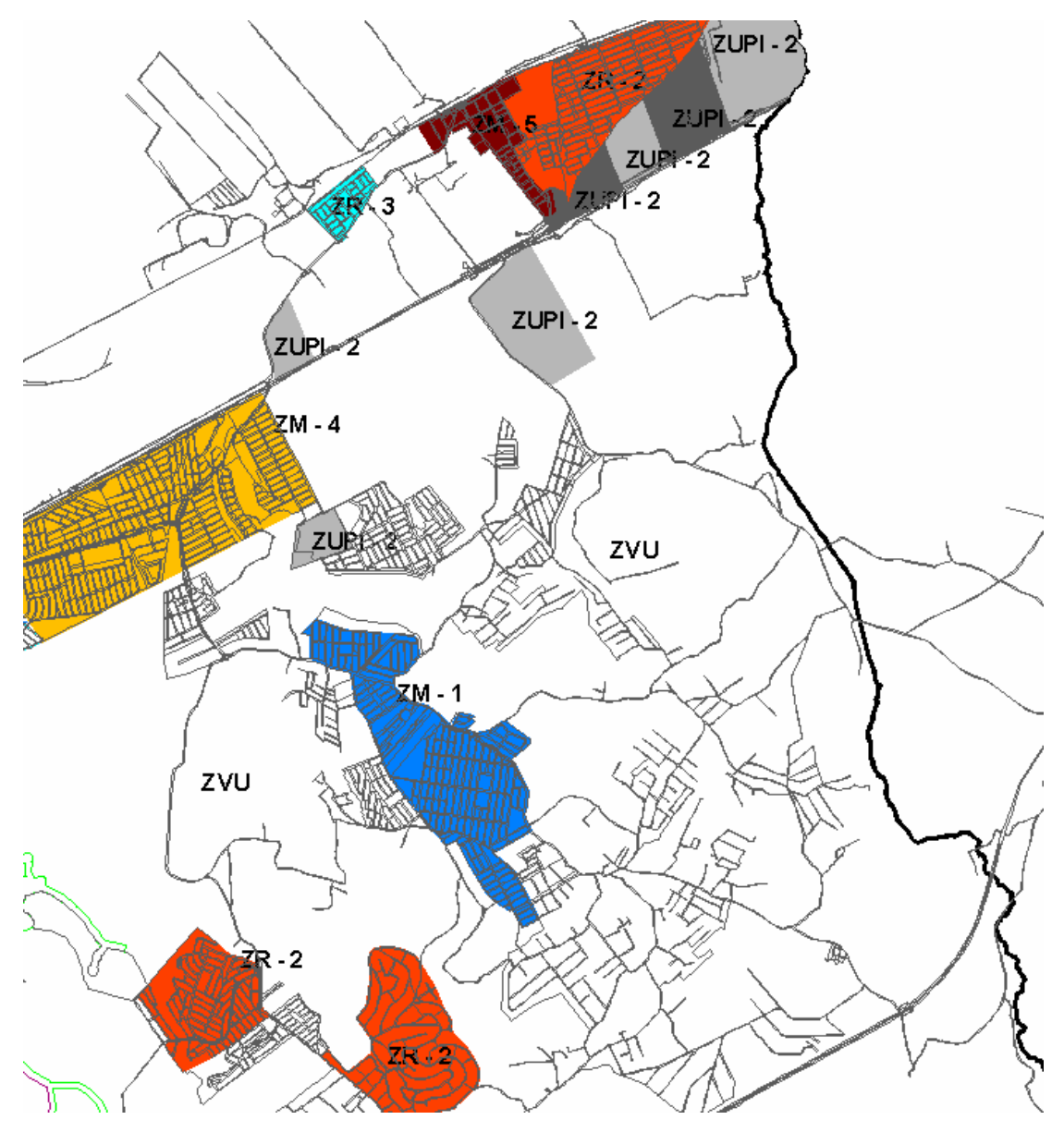

Figura 4.19 - Zona de Vazio Urbano - Lei Municipal 3721/90 Fonte: Secretaria de Planejamento, P.M.S.J.C., 2007.

O PDDI de 1995 e o Plano Diretor de 2006 apontaram como vetor de crescimento de São José dos Campos, a Região Leste.

Nessa região destacamos um outro exemplo dos efeitos da legislação no território e a necessidade de haver algum tipo de visão dos planejadores, um pouco maior, para se pensar os caminhos da ocupação municipal.

Como pudemos verificar, nessa região surgiram inúmeros loteamentos clandestinos. Verificamos também que entre esses loteamentos clandestinos existem vazios urbanos e essas glebas ficaram encravadas, isto é, sem frente para uma via oficial. 
Esse fato faz com que essas áreas não possam ser desmembradas e, muito menos, parceladas. O PDDI de 2006 propõe para a Região Leste um novo traçado de vias que visam, além de integrar essa região com as demais regiões do município, a oficialização dessas áreas. (fig. 4.20)

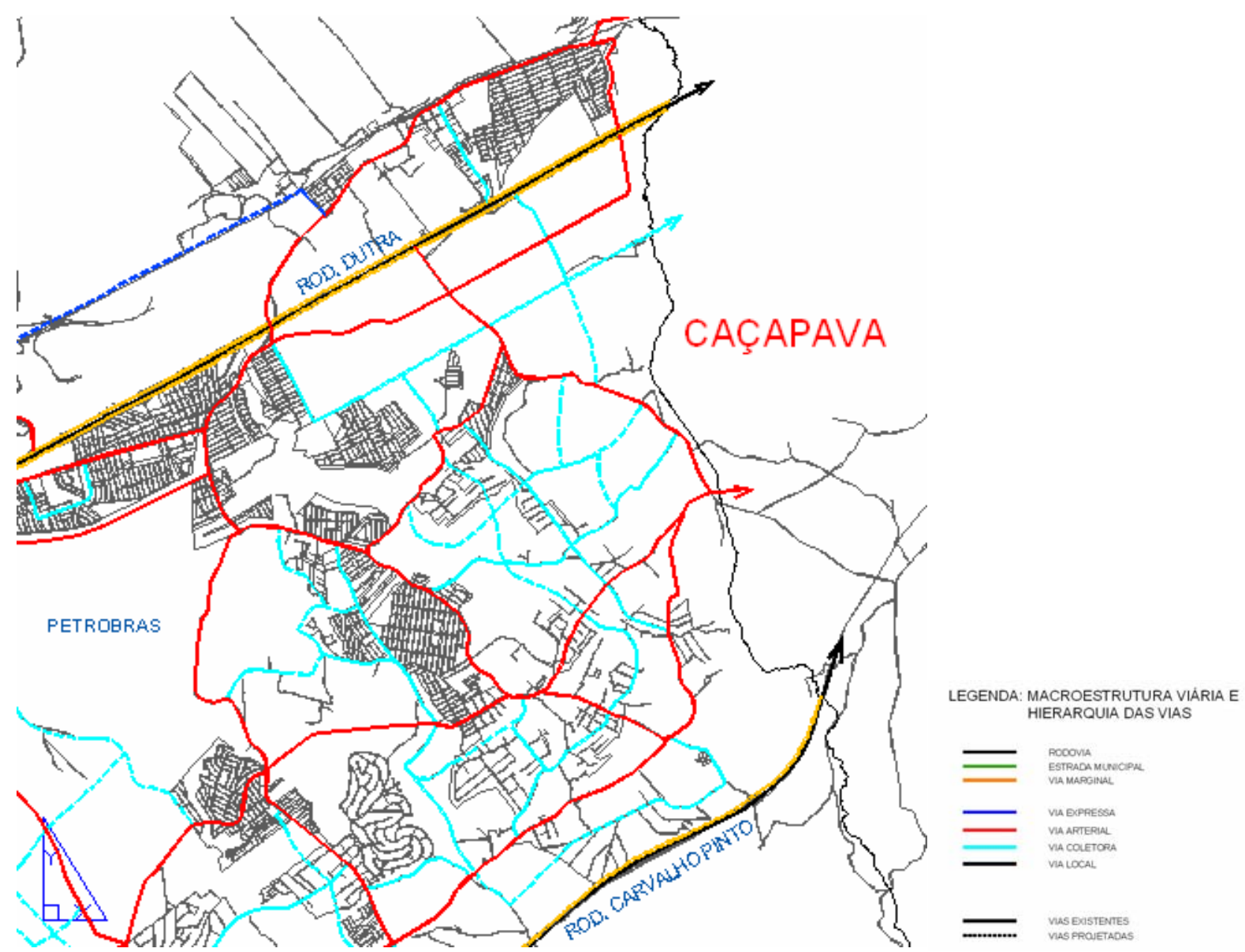

Figura 4.20 - Mapa da proposta viária para a Região Leste - PDDI 2006 Fonte: Secretaria de Planejamento Urbano, P.M.S.J.C., 2007.

O fato é que estão sendo projetadas grandes avenidas sobre áreas de ocupação irregular e essas vias projetadas irão passar por esses vazios, viabilizando o desmembramento e parcelamento dessas áreas.

Podemos dizer que as diretrizes propostas no PDDI de 2006, se concretizadas, haverá uma valorização do solo do setor 30 e a tendência de relocação da população de baixa renda para outros locais do território, possivelmente, nos limites urbanos de Caçapava, promovendo a segregação espacial. 


\section{- Área 3 - Região Oeste}

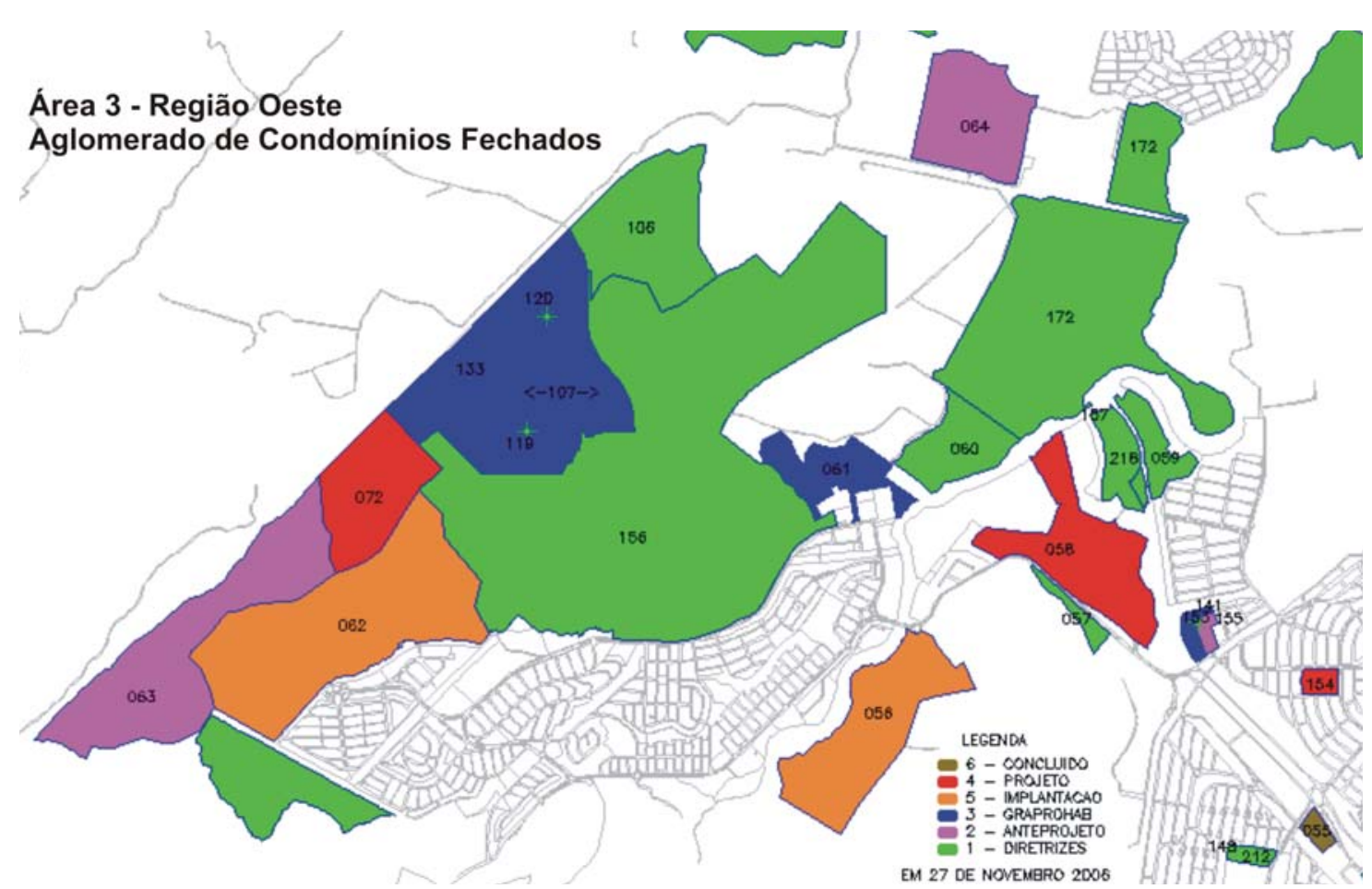

Figura 4.21 - Mapa da área 3 - Região Oeste

Fonte: Secretaria de Planejamento Urbano, P.M.S.J.C., 2007

Ao analisarmos o mapa de fases de loteamentos da Região Oeste, fig. 4.21, podemos verificar que esta região será ocupada por um grande número de condomínios fechados para uma população de maior renda.

Conforme a Lei Municipal de 1990, esta área também era uma zona de uso denominada Zona de Vazio Urbano. (fig. 4.22) 


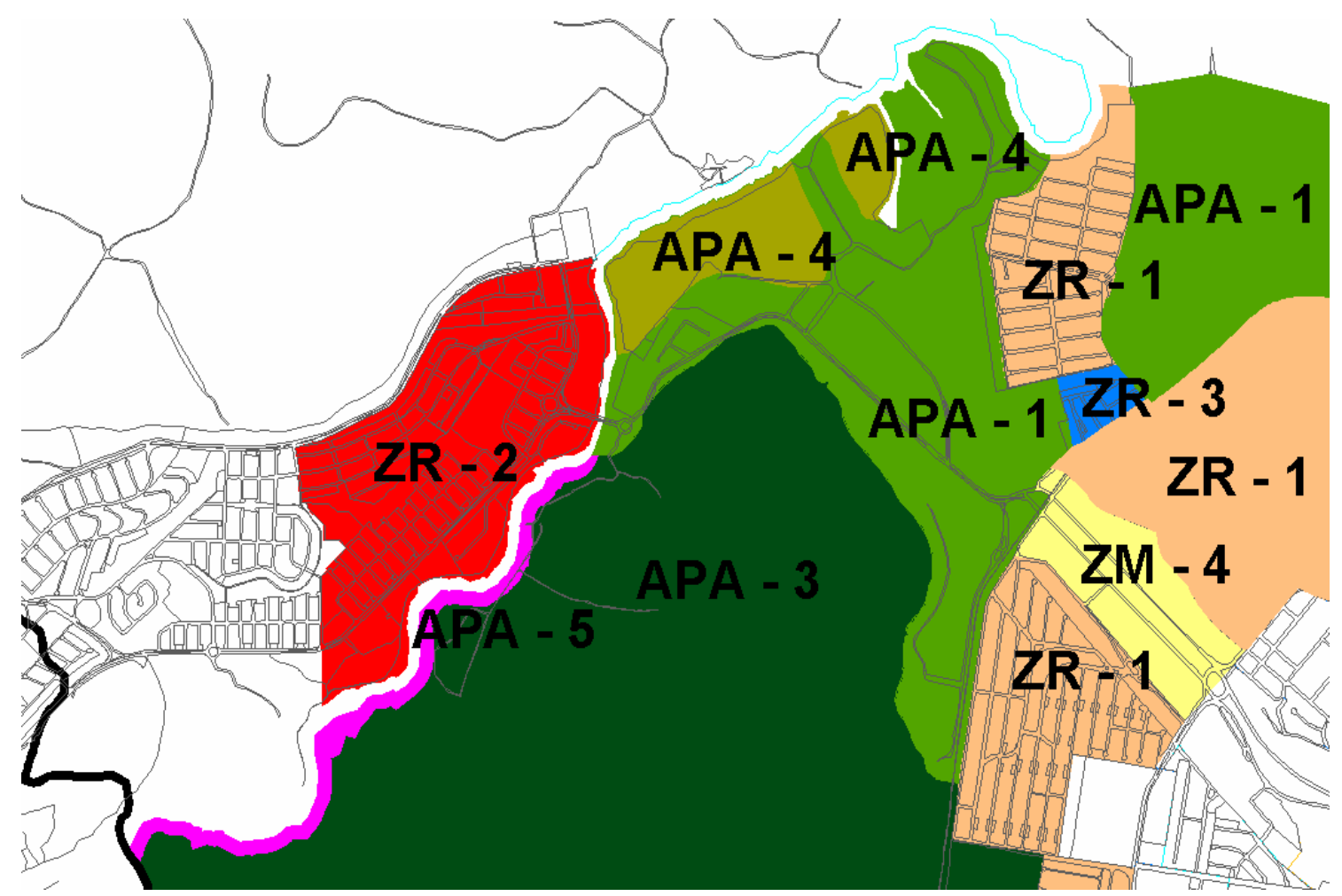

Figura 4.22 - Zoneamento da Região Oeste - Lei Municipal 3721/90 Fonte: Secretaria de Planejamento, P.M.S.J.C., 2007.

Na Lei Municipal de zoneamento de 1997, a Região Oeste era composta por zonas de uso residencial (ZR), mista (ZM2) e na sua maioria pela zona de uso de vazio urbano (ZVU).

O PDDI de 2006 propõe como diretrizes viárias, Fig. 4.23, a integração dessa região ao Anel Viário Municipal e, recentemente, o Governo do Estado de São Paulo vem concluindo a obra de prolongamento da Avenida Mário Covas que dará acesso à Rodovia Tamoios (Litoral Norte) e à Rodovia Carvalho Pinto (São Paulo e Campos do Jordão). 


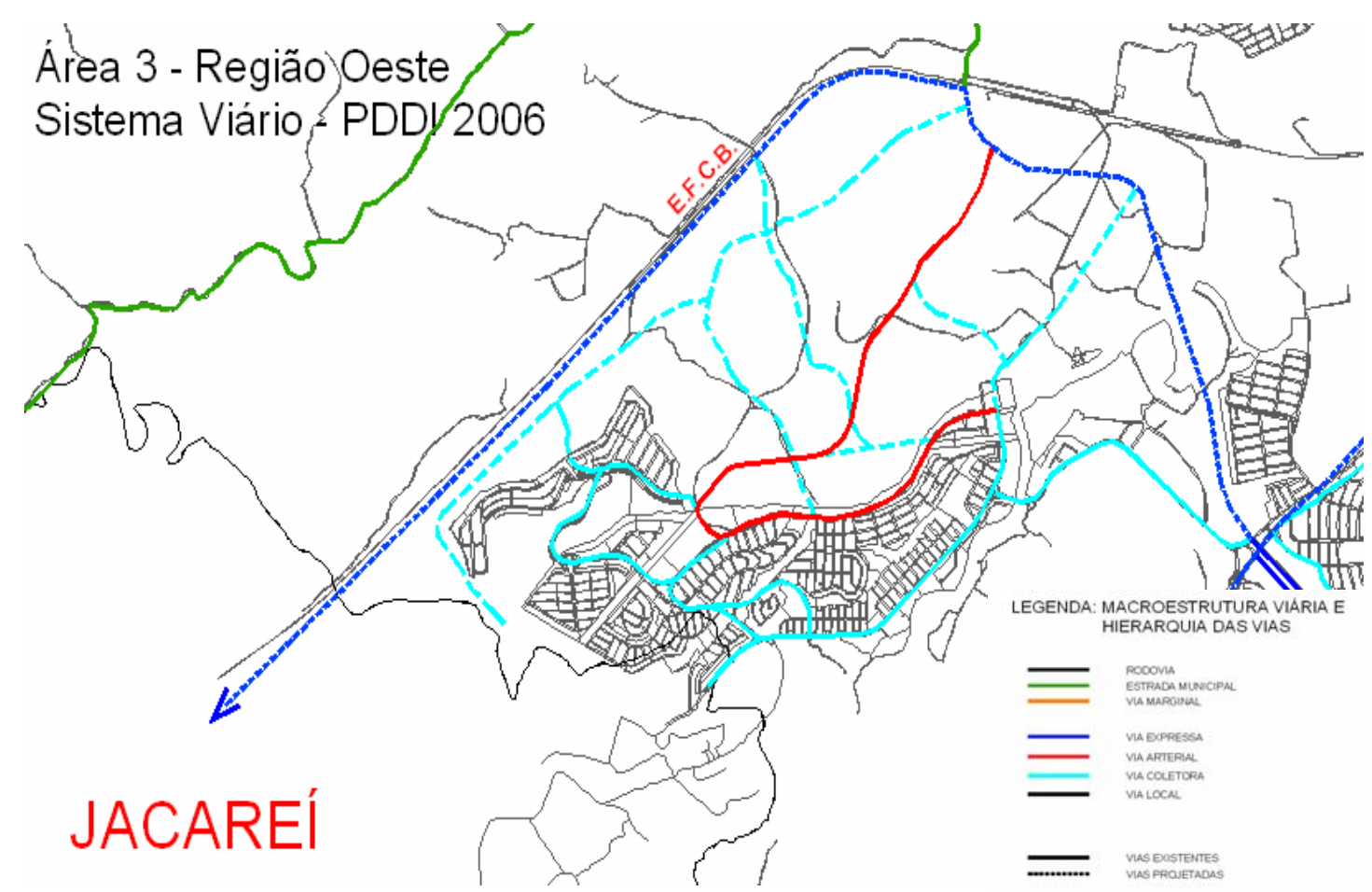

Figura 4.23 - Mapa da proposta viária para a Região Oeste - PDDI 2006 Fonte: Secretaria de Planejamento Urbano, P.M.S.J.C., 2007.

Na área 3, Região Oeste, também podemos observar como a existência dos usos nas áreas lindeiras dos municípios de São José dos Campos e Jacareí podem interferir no território municipal dessas cidades.

Como podemos verificar na fig. 4.24 há uma invasão nos limites de Jacareí pelo uso e ocupação do solo de São José dos Campos.

Fato interessante a ser observado é que os tributos e taxas referentes à essas ocupações são revertidos para São José dos Campos.

Em contra-partida, quatro cavas de extração de areia que estão oficialmente no território de São José dos Campos seus tributos são revertidos para Jacareí. 


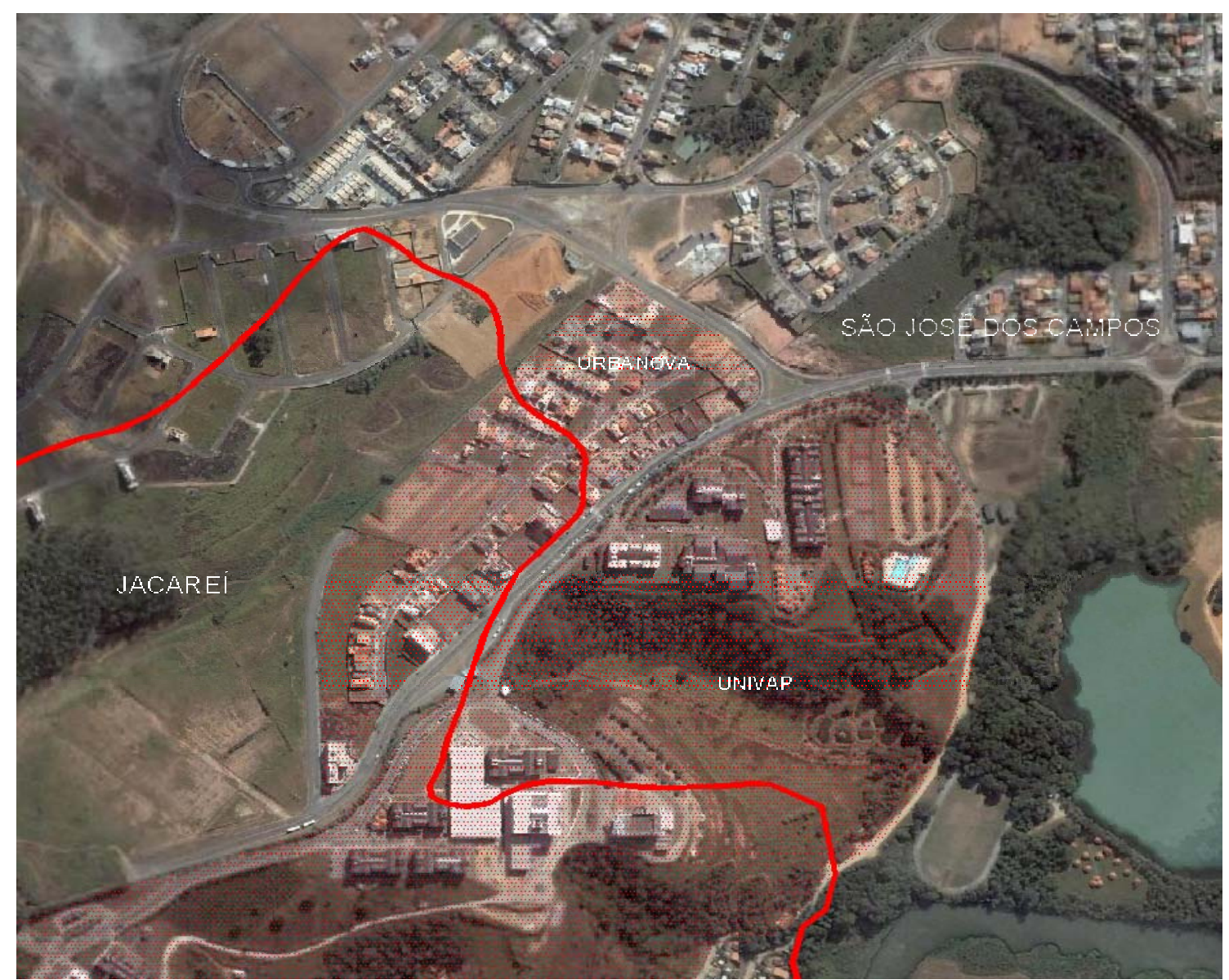

Figura 4.24 - Foto aérea e limite entre São José dos Campos e Jacareí - Região Oeste Fonte: Secretaria de Planejamento Urbano, P.M.S.J.C., 2007.

A área do lado de São José dos Campos é classificada como parte na Zona Mista Dois - ZM-2 e parte na Zona Residencial (ZR).

De acordo com o artigo 75 da Lei Complementar Municipal $n^{\circ}$ 165/97, a ZR constitui-se por áreas dotadas de infra-estrutura destinadas à ocupação predominantemente residencial unifamiliar e a ZM-2 constitui-se de áreas dotadas de infra-estrutura com tendência à intensificação da urbanização, na qual se permite maior adensamento, para melhor e maior otimização da infra-estrutura existente e ocupação dos terrenos ociosos, admitindo-se o uso residencial, o uso compatível com o uso residencial, uso sujeito a controle e uso industrial compatível com o uso residencial.

São José dos Campos, através da legislação municipal, orientava sua Região Oeste para uma ocupação com lotes maiores destinados para uma população de maior renda em regime de condomínios fechados. No outro lado desse limite, na Região Leste 
de Jacareí, os formuladores da legislação daquele município, com base nos estudos feitos pelo MAVALE, propunham em seu plano diretor a diretriz que, nessa área, a ocupação mais adequada deveria ser Zona Rural.

É interessante verificar que se trata de uma região com semelhanças quanto ao aspecto físico-geográfico, porém que receberam tratamento diferenciado na legislação de cada município.

De fato, a se manter a tendência habitual, a área destinada à ocupação rural, provavelmente, virá a ser ocupada por loteamentos clandestinos. O contrário, não acontecerá, o certo é que a implantação dos vários loteamentos fechados destinados à população de poder aquisitivo maior irá influenciar o uso e ocupação do solo em Jacareí.

Ao destacarmos de cada região analisada, três áreas que, apesar da legislação urbanística, vêm sendo modificada, pudemos observar que:

Na primeira análise, a legislação a ser proposta para a Região Norte virá a consolidar a implantação de loteamentos fechados que poderão causar prejuízos ao meio ambiente.

Na segunda análise, verificamos que a utilização da legislação foi elaborada para legalizar vazios urbanos que estão localizados entre os loteamentos clandestinos e pertencem a grupos do setor imobiliário. A tendência é a de que a população desses loteamentos será transferida para os limites de Caçapava ou para a Zona Rural de São José dos Campos localizada ao Sul do território.

Na terceira análise, verificamos que a existência dos usos nas áreas lindeiras de São José dos Campos e Jacareí interferem no espaço municipal dessas cidades.

A partir desses recortes urbanos, foi possível exemplificar e evidenciar o fato de que, embora São José dos Campos tenha uma expressiva legislação urbanística, seu não cumprimento pode continuar levando a situações indesejáveis em termos de uso e ocupação do solo, urbanos e intra-urbanos. 


\section{CONCLUSÃO}

A legislação urbanística produzida em São José dos Campos, desde a elaboração de suas primeiras leis, já incorporava a concepção de que elementos adequados a uma situação de desenvolvimento e crescimento poderiam servir para a solução de problemas urbanos do presente: dispersão territorial; barreiras viárias (Via Dutra); vazios urbanos; falta de integração viária; falta de uma política habitacional de interesse social; qualidade ambiental; gestão urbana; urbanização e legalização dos assentamentos precários; geração de recursos para habitação de interesse social.

No entanto, tais problemas ainda persistem, apesar da expressiva legislação urbanística.

A metropolização da Região do Vale do Paraíba vem se impondo desde os anos 70 e São José dos Campos assumiu o papel de uma metrópole emergente, o que pode ser verificado, principalmente, pelo caráter regional do setor de serviços que dá sustentação à intensificação dos fluxos e relações entre São José dos Campos e as cidades do seu entorno, compondo traços fundamentais do processo de metropolização da região do aglomerado do Vale do Paraíba.

Considerando a intensa dinâmica entre os municípios do Vale do Paraíba e que São José dos Campos é sede de um dos mais importantes aglomerados tecnológicos do país, fica evidente que os problemas urbanos elencados não afetam apenas uma ou outra cidade, mas o aglomerado como um todo. Por outro lado, constatou-se que cada um desses municípios ainda não assumiu seu devido papel nesse aglomerado para que, a partir disso, haja um enfrentamento dessa nova condição de "cidade regional".

Verificamos que esse espaço urbano define a feição do espaço nacional, ao mesmo tempo em que interpreta e realiza as diretrizes políticas, econômicas e sociais da nação - sintetizadas em uma política de urbanização, isto é, no projeto e também na 
prática de sua própria ordenação. Disto resulta que se impõe a efetiva formulação de uma política de urbanização e que o espaço não decorra da inércia dos responsáveis, ou ainda, da ausência deles.

Assim, apesar da intensa dinâmica entre os municípios do Vale do Paraíba, nota-se a ausência de uma efetiva política regional articulada e a não implantação de políticas integradas de uso do solo em nível metropolitano.

Sobre o crescimento econômico da região, constatamos que sempre existiu a preocupação do Estado em incrementar o desenvolvimento econômico, porém não houve, em nenhum momento da história de sua legislação urbanística, uma diretriz para a institucionalização dessa região como território metropolitano, nem sequer a possibilidade de administração de uma área metropolitana.

Cabe salientar que a experiência de outras regiões já demonstrou que não é possível conseguir um plano metropolitano satisfatório simplesmente pela coordenação ou entrosamento dos diversos planos municipais ou setoriais. Impõe-se a elaboração de um plano que envolva os municípios do aglomerado do Vale do Paraíba, onde seriam abordados os diversos aspectos do desenvolvimento dessa região, por uma autoridade metropolitana que trate esse espaço como um todo diferenciado e não apenas como a soma das partes.

Não se trata apenas de uma mudança de escala para que os problemas de uma ou outra cidade sejam resolvidos. Não adianta passarmos, simplesmente, do local para o regional para resolver os impasses urbanos no intra-urbano e, por fim, dizer que o espaço nacional se unificou, o que não significa afirmar que ele não tenha desigualdades internas. Ao contrário, suas desigualdades só existem porque o espaço é integrado. Identificá-los e relacioná-los no exercício em que eles são produzidos, seja intra-urbanos ou extra-urbanos, faz-se necessário para a devida compreensão e futuro enfrentamento por políticas públicas eficientes e claras nos seus objetivos. 
No caso apresentado, políticas públicas significam a aplicação sistemática de instrumentos urbanísticos que viabilizem: os programas de urbanização e legalização dos assentamentos precários, a formação de um estoque de terrenos públicos, a geração de recursos para a habitação de interesse social e a redução de parte dos vazios urbanos em áreas infra-estruturadas.

Trata-se, mais detalhadamente, de entender qual seria o interesse metropolitano e as questões de desenvolvimento metropolitano. Mais especificamente ainda, para a metropolização de São José dos Campos não basta apenas o controle institucional. A abordagem da produção do espaço como produção das relações sociais ali colocadas não é meramente uma questão de território, mas de fato uma "costura" de relações. Essas relações mudam e se alteram a cada intervenção ou a cada transformação nessa ou naquela cidade.

No caso do aglomerado do Vale do Paraíba, a diluição dos limites das cidades que o compõem - Jacareí, São José dos Campos, Caçapava, Taubaté, Tremembé e Pindamonhangaba - é passível de ser observada no encontro das periferias em suas fronteiras, sendo um dos fatores dessa diluição, o alto custo da terra próxima das zonas centrais dessas cidades.

O processo também ocorre não apenas porque o trabalho assalariado impõe a concentração espacial dos produtores diretos ou porque as indústrias ou o comércio necessitam dessa forma de organização espacial, mas, sobretudo, porque a urbanização - a dimensão espacial do avanço no processo de socialização dos custos da produção representado pela economia de mercado - significa, da mesma forma, uma crescente socialização do processo de reprodução social. Assim, o que observamos é que esse espaço se expressa dessa mesma forma: o todo não é, ainda, assumido pelas administrações dos municípios integrantes desse aglomerado. 
Para uma melhor compreensão dos efeitos da legislação urbanística em São José dos Campos procedemos três análises pontuais nas regiões Norte, Leste e Oeste deste Município. Ao destacarmos as três áreas analisadas que, apesar da legislação urbanística, vêm sendo modificadas, retomamos as seguintes conclusões:

Na primeira análise, área localizada na Região Norte, as diretrizes a serem proposta nos planos mais recentes, PDDI de 2006 e Plano Diretor do Parque da Cidade, provavelmente, virão a consolidar, para esta região, a implantação de loteamentos fechados, para uma população de maior renda, que poderão causar prejuízos ao meio ambiente. Esses planos apresentam em suas diretrizes a indução de ocupação da Várzea do Paraíba do Sul. Neste caso, salientamos que formas predatórias de ocupação por grandes empreendimentos do mercado e, pelo que conhecemos até o presente, a legislação ainda não conseguiu atingir e deter esse processo.

Na segunda análise, Região Leste, verificamos que a utilização da legislação urbanística proposta tem como objetivo legalizar vazios urbanos que estão localizados entre os loteamentos clandestinos e pertencem a grupos do setor construtivo e imobiliário. A tendência é a de que a população desses loteamentos será transferida para os limites de Caçapava ou para a Zona Rural de São José dos Campos localizada ao Sul do território, promovendo a segregação espacial.

Na terceira análise, Região Oeste, verificamos que a existência dos usos nas áreas lindeiras de São José dos Campos e Jacareí interferem no espaço físico municipal dessas cidades.

Portanto, a partir desses recortes urbanos, foi possível exemplificar e evidenciar que embora São José dos Campos tenha uma expressiva legislação urbanística, seu não cumprimento pode continuar levando a situações indesejáveis em termos de uso e ocupação do solo intra e extra-urbanos. 
Considerando a intensa dinâmica entre os municípios do aglomerado do Vale do Paraíba e a compreensão de que o local é o geral em seu processo de formação do espaço, seria proveitoso, além de promover uma política regional articulada, serem estudadas e implantadas políticas integradas de uso do solo em nível metropolitano.

Para a solução dos problemas urbanos de São José dos Campos, os quais vêm extrapolando os limites municipais, certamente, exigirá das Administrações Municipais do aglomerado do Vale do Paraíba, não só uma abordagem regional, mas a aplicação de instrumentos urbanísticos que viabilizem: os programas de urbanização e legalização dos assentamentos precários, a formação de um estoque de terrenos públicos, a geração de recursos para a habitação de interesse social e a redução de parte dos vazios urbanos em áreas infra-estruturadas. 


\section{REFERÊNCIAS}

AZEVEDO, E. Avaliação do planejamento municipal no Estado de São Paulo: relatório de pesquisa. São Paulo: FAPESP, USP, EESC, 1976.

BIRKHOLZ, L.B. Planos diretores municipais no Estado de São Paulo e sua implantação. São Paulo: FAUUSP, 1964.

BONDUKI, N. G. À guisa de conclusão: das experiências concretas para a construção de um novo ideário em políticas urbanas. In: Habitat: as práticas bem sucedidas em habitação e meio ambiente e gestão urbana nas cidades brasileiras. São Paulo: Nobel, 1996.

CANO, W. Raízes da concentração industrial em São Paulo. Rio de Janeiro: DIFEL, 1977.

CASTELLS, M. A questão urbana. Rio de Janeiro: Paz e Terra, 1983. (Coleção Pensamento Crítico; v. 48)

A sociedade em rede. 7. ed. São Paulo: Paz e Terra, 2003. v. 1.

CHOAY, Françoise. O reino do urbano e a morte da cidade. In: Projeto História, São Paulo, n. 18, maio de 1999, p. 67-89.

O urbanismo. São Paulo: Perspectiva, 1979.

CODIVAP - Caracterização do conhecimento existente sobre a região do Vale do Paraíba. Pindamonhangaba, São Paulo, 1971.

FELDMAN, S. Planejamento e zoneamento Tese (Doutorado em Arquitetura e Urbanismo) - Faculdade de Arquitetura e Urbanismo, Universidade de São Paulo, São Paulo: USP, 1996.

Planejamento e zoneamento. São Paulo: 1947 - 1972. São Paulo: Editora USP. São Paulo / Fapesp, 2005.

FLÓRIO, J. Relatório da Inspeção preliminar do município e estância hidromineral e climática de São José dos Campos. Apresentado ao Departamento de Saúde Pública do Estado de São Paulo, s.n., 1944. Datilografado.

FRIEDMANN, J. \& WOLFF, G. World city formation: an agenda for research and action. International Journal of Urban and Regional Studies, v. 6, n. 3, setembro, p.309-344, 1986.

- Plano Regional do Macro-Eixo Paulista. Secretaria de Economia e Planejamento. São Paulo, 1978.

GOTTDIENER, M. A teoria da crise e a reestruturação sócio-espacial: o caso dos Estados Unidos. In: VALLADARES, Licia; PRETECEILLE, Edmond (org.). Reestruturação urbana: tendências e desafios. São Paulo: Nobel/luperj, 1990. 
GUARESCHI, N. et all Poblematizando as práticas psicológicas no modo de entender a violência. In: Violência, gênero e políticas públicas. Orgs. STREY, M. et all. Porto Alegre: Epicurus, 2004.

IPEA, IBGE, UNICAMP. Caracterização e tendências da Rede Urbana do Brasil: configurações atuais e tendências da rede urbana. Brasília: IPEA, 2001. v.1.

JAMESON, S.H. Administração Municipal. São Paulo: Fundação Getúlio Vargas, 1965. V. X.

LENCIONI, S. Reestruturação Urbano-industrial no Estado de São Paulo: a Região da Metrópole desconcentrada. Espaço e Debates, São Paulo, n. 38, p. 54-61, 1994.

MARICATO, E. Metrópole na periferia do capitalismo: ilegalidade, desigualdade e violência. São Paulo, HUCITEC, 1996.

MARTINS, J.S. A sociedade vista do abismo: novos estudos sobre exclusão, pobreza e classes sociais. Petrópolis: Vozes, 1996.

MEYER, R.M.P; GROSTEIN, M.D.; BIDERMAN, C. São Paulo Metrópole. São Paulo: USP, Imprensa Oficial do Estado de São Paulo, 2004.

MORI, K.K. Brasil: urbanização e fronteiras. Tese (Doutorado em Arquitetura e Urbanismo) - Faculdade de Arquitetura e Urbanismo, Universidade de São Paulo, São Paulo: USP, 1996.

NEGRI B. A Interiorização da Indústria Paulista (1920 - 1980), In: CANO, W. A Interiorização do Desenvolvimento Econômico no Estado de São Paulo. SEADE / FECAMP/ UNICAMP, 1988, vol. 1, $\mathrm{n}^{\circ} 2$.

OLIVEIRA, L. \& TARTAGLIA, J.C. A Agricultura Paulista e sua Dinâmica Regional (1920 - 1980), in CANO, W. (org.), 1988.

PREFEITURA MUNICIPAL DE SÃO JOSÉ DOS CAMPOS. Consolidação das leis tributárias do município de São José dos Campos. São José dos Campos: SMF, 1995.

Legislação de parcelamento, uso e ocupação do solo. São José dos Campos: SPMA, 1970 -1997.

Plano Diretor do Município de São José dos Campos: Plano Preliminar. São José dos Campos: PMSJC, 1961.

Plano Diretor do Município de São José dos Campos. Estudos e Planos Setoriais. São José dos Campos: PMSJC, 1964. v.1-2.

Plano Preliminar de São José dos Campos. São Paulo: Faculdade de Arquitetura e Urbanismo - Universidade de São Paulo, Centro de Pesquisas e Estudos Urbanísticos, Prefeitura de São José dos Campos, Departamento de Obras Sanitárias, São José dos Campos, 1961.

Plano Setoriais para São José dos Campos. São Paulo: Faculdade de Arquitetura e Urbanismo - Universidade de São Paulo, Centro de Pesquisas e Estudos 
Urbanísticos, Prefeitura de São José dos Campos, Departamento de Obras Sanitárias, São José dos Campos, 1964.

Plano Diretor de Desenvolvimento Integrado de São José dos Campos. SERETE Engenharia S/A e Prefeitura Municipal de São José dos Campos, 1971.

Plano Diretor de Desenvolvimento Integrado de São José dos Campos. Prefeitura Municipal de São José dos Campos, 1994.

REIS, N.G. Notas sobre urbanização dispersa e novas formas de tecido urbano. São Paulo: Via das Artes, 2006.

RIBEIRO. M.A.C. A Complexidade da Rede Urbana Amazônica: três dimensões de análise. 1998, 335 f. Tese (Doutorado em Geografia). Departamento de Geografia. Universidade Federal do Rio de Janeiro, 1998.

SANTOS, A. De cobaia a feiticeiro. Cadernos CIRC. São José dos Campos, n.1, dez / 1996.

SANTOS, E. A Evolução Urbano-Industrial e a Transformação da paisagem: O caso de São José dos Campos. Dissertação (Mestrado em Arquitetura e Urbanismo) Faculdade de Arquitetura e Urbanismo, Universidade de São Paulo. São Paulo: FAUUSP, 1993.

SANTOS, M. A Natureza do Espaço: Técnica e Tempo, Razão e Emoção. 4 ed. São Paulo: EDUSP, 2004.

A Urbanização Brasileira. São Paulo: Hucitec, 1994.

SANTOS, P.A.L. Estado e Planejamento: a experiência dos planos diretores de Natal: UFRGN, 1989.

SCOTT, A.J. \& STORPER, M. Indústria de alta tecnologia e desenvolvimento regional: uma crítica e reconstrução teórica. Espaço e Debates n² 25. 37-42 São Paulo, 1988.

SCHERER, R. Sistematização Crítica do Conjunto dos Trabalhos. São Paulo: Tese (Livre-Docência em Arquitetura e Urbanismo) - Universidade de São Paulo. São Paulo: FAU-USP, 1994.

SEADE / FECAMP/ UNICAMP, 1988, vol. 1, $\mathrm{n}^{\circ} 2$.

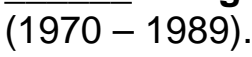

Diagnóstico Setorial: A Indústria de Transformação do Estado de São Paulo

SEN, A. O desenvolvimento como expansão de capacidades. São Paulo: Lua Nova, CEDEC, $n^{\circ}$ 28/29, p. 313-333, 1993.

VILLAÇA, F. As Ilusões do Plano Diretor. Publicado em agosto de 2005. Disponível em: http// www.usp.br/fau/fau/galeria/páginas/index.html. Acesso: 22/01/2006.

Uma contribuição para a história do planejamento urbano no Brasil. In: 0 processo de urbanização no Brasil. São Paulo: USP, 1999. 


\section{OBRAS CONSULTADAS}

ABRAMO, P. Mercado e ordem urbana. Rio de Janeiro: Bertrand Brasil: FAPERJ, 2001.

AMARAL, J.F. Relatório apresentado à cadeira de Hygiene da Faculdade de Medicina de São Paulo como inspeção sanitária no Município de São José dos Campos. São Paulo, set/1930.

ARANTES, O.B.F. O urbanismo em fim de linha. São Paulo: Editora da Universidade de São Paulo, 2001.

ALVES, O.R. Os homens que governam São Paulo. São Paulo: EDUSP, 1986.

BECKER, B.K. Os Eixos de Integração e Desenvolvimento e a Amazônia. Revista Território, ano IV, nº 06. Rio de Janeiro jan./jun.1999.

BENEVOLO, L. As origens da urbanística moderna. São Paulo: Ed. Martins Fontes, 1981.

BERTOLLI F.C. História social da tuberculose e do tuberculoso (1900 - 1950). Tese (Doutorado em História) - Faculdade de Filosofia, Letras e Ciências Humanas da Universidade de São Paulo, 1993. $\overline{\operatorname{dez} / 1996 .}$

São José e a ditadura Varguista. Cadernos CIRC. São José dos Campos, n. 1,

BITTENCOURT, T.M.M. Arquitetura Sanatorial. São José dos Campos: Artes Gráficas, 1998.

BOLOGNA, S.M.F. Experiência dos Planos Diretores de São José dos Campos: Instrumentos eficazes de planejamento urbano ou obras de consulta acadêmica. Dissertação de Mestrado - Instituto de Pesquisa e Desenvolvimento (IPD) - Universidade do Vale do Paraíba, São José dos Campos, SP, 2000.

BONDESAN, A. São José em quatro tempos. São Paulo: Bentivegna, 1967.

São José de ontem e de hoje. São José dos Campos: JAC, 1996.

BORJA, J.; CASTELLS, M. Local y Global: La gestión de lãs cidades em la era de la información. Madrid, 1999.

BRAUDEL, F. A Dinâmica do Capitalismo. Rio de Janeiro: Rocco, 1987.

CALDEIRA, JN (Org.). Álbum de São José dos Campos (1934). São Paulo: Cruzeiro do Sul, 1934.

CAMARA, S.P. Almanach de São José dos Campos (1905). Jacarehy: Typographia da "Casa Minerva", 1905.

CAMPOS F.C.M. Reinvente seu bairro. São Paulo: Editora 34, 2003. 
Cidades brasileiras: seu controle ou caos. São Paulo: Studio Nobel, 2001. $\overline{\text { (Cidade Aberta) }}$

CANO, W. Relatórios de Pesquisa, Convênio IPT / FECAMP / UNICAMP, 1990.

CARDOSO, F.H. O Estado e o Capital apud SANTOS, Pedro Antonio de Lima. Estado e Planejamento: a experiência dos planos diretores do Brasil. Natal-RN: UFRGN, 1989. p.73.

CESCO, N.T. São José dos Campos: uma visão da fase sanatorial. São José dos Campos: Fundação Cultural Cassiano Ricardo, 1992.

CARLOS, A.F.A. A cidade. São Paulo: Contexto, 2003. Coleção Repensando a Geografia.

$\overline{\text { Geografia. }}$

Espaço e indústria. São Paulo: Contexto, 1989. Coleção Repensando a

CHUSTER, V. O zoneamento de 1971 a 1997 em São José dos Campos. Dissertação (Mestrado) Instituto de Pesquisa e Desenvolvimento (IPD), Universidade do Vale do Paraíba, São José dos Campos, 1998.

CORRÊA, R.L. Hinterlândia, Hierarquias e Redes: Uma avaliação da Produção Geográfica Brasileira. In: CARLOS, Ana Fani Alessandri (Org.). Os Caminhos da Reflexão sobre a Cidade e o Urbano. São Paulo: EDUSP, 1994.

A Rede Urbana. São Paulo: Ed. Ática, 1986.

Trajetórias Geográficas. 2. ed. Rio de Janeiro: Bertrand Brasil, 2001.

COSTA, W.M. Subsídios para uma política nacional de ordenamento territorial. São Paulo: FFLCH, 2003.

DUPAS, G. Economia Global e Exclusão Social. São Paulo: Editora Paz e Terra, 2001. $\overline{\text { Terra, } 2003 .}$

Tensões contemporâneas entre o público e o privado. São Paulo: Paz e

FURTADO, C. O capitalismo global, São Paulo: Paz e Terra, 2000.

GOVERNO DO ESTADO DE SÃO PAULO. Ação Regional. Secretaria de Economia e Planejamento / Coordenadoria de Ação regional. São Paulo, s/d.

Política de desenvolvimento urbano e regional. Secretaria de Economia e Planejamento, São Paulo, 1978.

GROSTEIN, M.D. A cidade clandestina: os ritos e os mitos - o papel da "irregularidade" na estruturação do espaço urbano no município de São Paulo - 1900 - 1987 Tese (Doutorado em Arquitetura e Urbanismo). Universidade de São Paulo, São Paulo: USP, 1987.

GUNN, P. Urbanização do Sudeste: dominação das metrópoles? In: GONÇALVES, M.F. (org.) O novo Brasil urbano: impasse, dilemas e perspectivas. Porto Alegre: Mercado Aberto, 1933, p. 85-111. 
HARVEY, D. Condição pós-moderna. São Paulo: Loyola, 1992.

IANNI, O. A sociedade global. Rio de Janeiro: Civilização Brasileira, 1992.

INSAURALDE C.J.C. Desenvolvimento Econômico e Urbanização: Estudo de Caso do Município de São José dos Campos (1960 - 1985). Campinas-SP: UNICAMP, 1988.

KOWARICK, L. A espoliação urbana. São Paulo: Paz e Terra, 1986.

LEITE, L.G. Ordenamento territorial, zoneamento - uso e ocupação do solo. São Paulo: Fundação Prefeito Faria Lima, Centro de Estudos e Pesquisas de Administração Municipal, 1991.

LENCIONI, S. Região e Geografia. São Paulo: EDUSP, 2003.

LESSA, S.N. São José dos Campos: o planejamento e a construção do pólo regional do Vale do Paraíba. Tese (Doutorado) - Instituto de Filosofia e Ciências Humanas, Universidade Estadual de Campinas, Campinas, 2001.

LIPIETZ, A. O local e o global: personalidade regional ou interregionalinadade? In: Espaço \& Debate, $n^{\circ}$ 38, ano XIV, São Paulo: USP, 1994. p. 10-20.

MANCUSO, F. Las experiências del zoning. Barcelona: Gustavo Gili, 1980.

MARX, K. "Assim chamada acumulação primitiva" In O capital: a crítica da economia política. São Paulo: abril, 1983.

MARX, K. \& ENGELS, F. A ideologia alemã. São Paulo: Martins Fontes, 1998. (Clássicos)

MASCARENHAS, R.S. Contribuição para o estudo da administração dos serviços estaduais de tuberculose em São Paulo. Tese (Professor Catedrático de técnica de saúde pública) - Faculdade de Higiene e Saúde Pública, Universidade de São Paulo, 1953.

MEYER, R.M.P. Segregação espacial. A luta pelo espaço urbano. Petrópolis: Vozes, 1978.

MONCLÚS, F.J. Estratégias Urbanísticas y crecimiento suburbano em lãs ciudades españolas: el caso de Barcelona. Barcelona, 1998, p. 5-15.

MONTEIRO, Y.D.P. Subsídios para a elaboração do plano diretor. São Paulo: Fundação Prefeito Faria Lima, 1990.

MOREIRA, F.D. A formação do urbanismo moderno no Brasil: as concepções urbanísticas do engenheiro Saturnino de Brito. In: Espaço \& Debates. São Paulo, n. 40, 1997.

MOREIRA, M. (org.). Estatuto da cidade. São Paulo: Fundação Prefeito Faria Lima, 2001.

MULLER, N.L. O fato urbano na bacia do Rio Paraíba. Rio de Janeiro: Fundação IBGE - Instituto Brasileiro de Geografia, 1969. 
OLIVEN, R.G. Urbanização e mudança social no Brasil. Petrópolis: Vozes, 1982.

PACHECO, C.A. A Região Administrativa do Vale do Paraíba, Coleção São Paulo no Limiar do Século XXI, Governo do Estado de São Paulo. FSEADE, 1992, vol. 8.

São José dos Campos. Relatório de Pesquisa. São Paulo: FECAMP / UNICAMP, 1988.

PARREIRA, A.M. Uma geração entre duas crises do café. São Paulo: Revista dos Tribunais, 1959.

PENEDO, A. Arquitetura Moderna. São José dos Campos: Artes Gráficas, 1997.

PEREIRA, L. (org.). Populações "marginais”. São Paulo: Livraria duas cidades, 1978. (História e sociedade)

PORTAS, N. Tendências do Urbanismo da Europa. In: Revista Óculum. Campinas: FAUPUCCAMPINAS, n. 3, março 1993.

A política de reforço das centralidades. In Almeida, Marco Antônio Ramos de. 0 $\overline{C e n t r o}$ da Metrópole: reflexões e propostas para a cidade democrática do século XXI. São Paulo: Terceiro Nome; Viva o Centro; Imprensa Oficial do Estado, 2001, p. 12133.

PREFEITURA DE SÃO JOSÉ DOS CAMPOS. RELATÓRIO do Prefeito Sanitário Dr. Francisco José Longo (24 de agosto de 1938).

1941).

RELATÓRIO do Prefeito Sanitário Jorge de Molina Cintra (24 de outubro de

RAFFESTIN, C. Por uma geografia do Poder. São Paulo: Ática, 1980.

ROCHEFORT, M. Redes e Sistemas: Ensinando sobre o Urbano e a Região. São Paulo: Editora Hucitec, 1998.

ROLNIK, R. A cidade e a lei. São Paulo: Studio Nobel, 1997.

ROLNIK, R.; KOWARICK, L. \& SOMEKH, N. (orgs.). São Paulo: Crise e Mudança. São Paulo: Editora Brasiliense, 1990.

SANTOS, A.P. Arquitetura Industrial. São José dos Campos: Artes Gráficas, 2006.

SANTOS, M. Metrópole corporativa fragmentada: O caso de São Paulo. São Paulo: Nobel, 1990.

$\overline{\text { EDUSP, }} 2004$.

A Natureza do Espaço: Técnica e Tempo, Razão e Emoção. 4. ed. São Paulo:

SCHERER, R. Notas sobre Planejamento e Método. São Paulo: Cadernos de pesquisa LAP, $\mathrm{n}^{\circ}$ 10: FAU-USP, 1998.

Descentralização e Planejamento Urbano no Município de São Paulo. Tese (Doutorado em Arquitetura e Urbanismo) - Universidade de São Paulo. São Paulo: FAUUSP,1987. 
SECCHI, B. Tracce di città: nuovi scenari per la città europea. In: MUNARIN, Stefano; TOSI, Maria Chiara. Tracce di città - Explorazioni di um território abitato: l'área veneta. Milano: Franco Angeli / Urbanística, 2001, p. 213-221.

SCHIFFER, S.R. São Paulo: A descentralização Industrial e a Nova Territorialidade. In: FAUUSP. p. 73-82, 1992.

SECRETARIA DE ECONOMIA E PLANEJAMENTO DO ESTADO DE SÃO PAULO. Padrões funcionais e espaciais da rede urbana do Estado de São Paulo. Coordenadoria de Ação Regional. São Paulo, 1975.

SILVA, J.A. Direito urbanístico brasileiro. São Paulo: Malheiros Editores, 1997.

SOJA, E. Geografias Pós-Modernas: A Reafirmação do Espaço na Teoria Social Crítica. Rio de Janeiro: Jorge Zahar, 1993.

SOUSA, A.M.S. \& Soares, L. L. Modernidade e urbanismo sanitário: São José dos Campos. São José dos Campos-SP: Papercrom, 2002.

SOUZA, M.A.A. O novo Brasil Urbano: integração ou fragmentação? In: GONÇALVES, Maria Flora (org.). O novo Brasil Urbano: impasse, dilemas e perspectivas. Porto Alegre: Mercado Aberto, 1993.

TANAKA, M.S. Notas sobre as áreas urbanizadas dispersas e centrais: 1970-2000. Regiões de governo de São José dos Campos e Taubaté. São Paulo: Cadernos de pesquisa LAP, $n^{\circ}$ 47: FAU-USP, 2005.

VALLADARES, L.; PRETECEILLE, E. (org.). Reestruturação urbana: tendências e desafios. São Paulo: Nobel /Luperj, 1990.

VEIGA, J.E. A insustentável utopia do desenvolvimento. In: Reestruturação do espaço urbano e regional no Brasil. Lena Lavinas (org.), Hucitec, São Paulo, 1993.

- Cidades Imaginárias: O Brasil é menos urbano do que se calcula. Campinas, SP: Autores Associados, 2003.

VILLAÇA, F. A crise do planejamento urbano. São Paulo em Perspectiva, São Paulo, v.9, n.2, p.45-51, abr./jun.1995.

Espaço Intra-urbano no Brasil. São Paulo: Studio Nobel FAPESP, Lincoln Institute, 1998.

Sistematização crítica da obra escrita pelo prof. Dr. Flávio J. M. Villaça sobre espaço urbano Tese (Livre-Docência Arquitetura e Urbanismo) - Faculdade de Arquitetura e Urbanismo, Universidade de São Paulo. São Paulo: FAU-USP, 1988.

Uso do solo urbano. São Paulo: Fundação Prefeito Faria Lima, Centro de

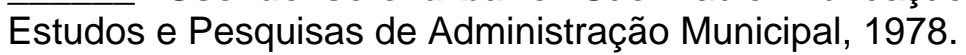


AUTORIZO A REPRODUÇÃO E DIVULGAÇÃO TOTAL OU PARCIAL DESTE TRABALHO, POR QUALQUER MEIO CONVENCIONAL OU ELETRÔNICO, PARA FINS DE ESTUDO E PESQUISA, DESDE QUE CITADA A FONTE.

\section{ASSINATURA:}

E-MAIL: paolohot@hotmail.com

Costa, Paulo Eduardo Oliveira

C837L Legislação urbanística e crescimento urbano em São José dos Campos / Paulo Eduardo Oliveira Costa. -São Paulo, 2007. 257 p.: il.

Dissertação (Mestrado - Área de Concentração: História e Fundamentos da Arquitetura e Urbanismo ) - FAUUSP. Orientadora: Rebeca Scherer

1.Legislação urbana - São José dos Campos(SP) 2.Urbanização 3.Planejamento municipal 4.Planejamento territorial regional 5.Segregação urbana I.Título 